\title{
Luís Felipe Carvalho
}

Mediação de cursos online abertos e massivos (MOOC) e seus efeitos na participação e desempenho dos estudantes

\section{Tese de Doutorado}

Tese apresentada ao Programa de Pós-graduação em Educação da PUC-Rio como requisito para obtenção do grau de Doutor em Educação.

Orientadora: Prof ${ }^{\mathrm{a}}$ Gilda Helena Bernardino de Campos 


\title{
Luís Felipe Carvalho
}

\begin{abstract}
Mediação de cursos online abertos e massivos (MOOC) e seus efeitos na participação e desempenho dos estudantes
\end{abstract}

Tese apresentada como requisito parcial para obtenção do grau de Doutor pelo Programa de Pós-graduação em Educação do Departamento de Educação do Centro de Teologia e Ciências Humanas da PUC-Rio. Aprovada pela Comissão Examinadora abaixo assinada.

\author{
Prof‥ Gilda Helena Bernardino de Campos \\ Orientadora \\ Departamento de Educação - PUC-Rio
}

Prof. Bernardo Pereira Nunes

PUC-Rio

Prof. Leonel Estevão Finkelsteinas Tractenberg

Universidade do Estado do Rio de Janeiro

Prof. Ralph Ings Bannell

Departamento de Educação - PUC-Rio

Prof. Sean Wolfgand Matsui Siqueira

Universidade Federal do Estado do Rio de Janeiro

Prof ${ }^{\mathrm{a}}$ Monah Winograd

Coordenadora Setorial do Centro

de Teologia e Ciências Humanas - PUC-Rio

Rio de Janeiro, 21 de fevereiro de 2018 
Todos os direitos reservados. É proibida a reprodução total ou parcial do trabalho sem autorização da universidade, da autora e do orientador.

\section{Luís Felipe Carvalho}

Professor do Departamento de Administração de Empresas da PUC-Rio, lecionando nos campos de empreendedorismo e inovação desde o ano de 2010. Durante cinco anos coordenou o centro de empreendedorismo da Universidade. Atualmente atua junto com outros professores da instituição na coordenação conjunta do Núcleo de Pesquisa Magis, cujo foco está ligado às temáticas de Inovação e Transformação Digital. Possui graduação em Ciências Contábeis pela UFRJ e mestrado em Administração de Empresas pela PUC-Rio, com especialização em Empreendedorismo e Inovação pela WHU - Otto Beisheim School of Business na Alemanha. Atualmente atua na interface entre educação, mídias digitais e novos modelos de organização baseados em tecnologias emergentes. Em 2014 criou junto com dois ex-alunos a primeira Hackathon brasileira focada no público universitário. Atualmente este evento se transformou no Hacktudo - o maior festival de cultura digital da cidade do Rio de Janeiro. Desde o ano de 2015 vem dando especial atenção ao tema de Blockchain e Moedas Virtuais, tendo sido pioneiro na criação da primeira disciplina de graduação do Brasil nesta área. Em 2017 criou o primeiro curso massivo online e aberto (MOOC) neste mesmo tema, servindo de base para sua tese de doutorado.

Ficha Catalográfica

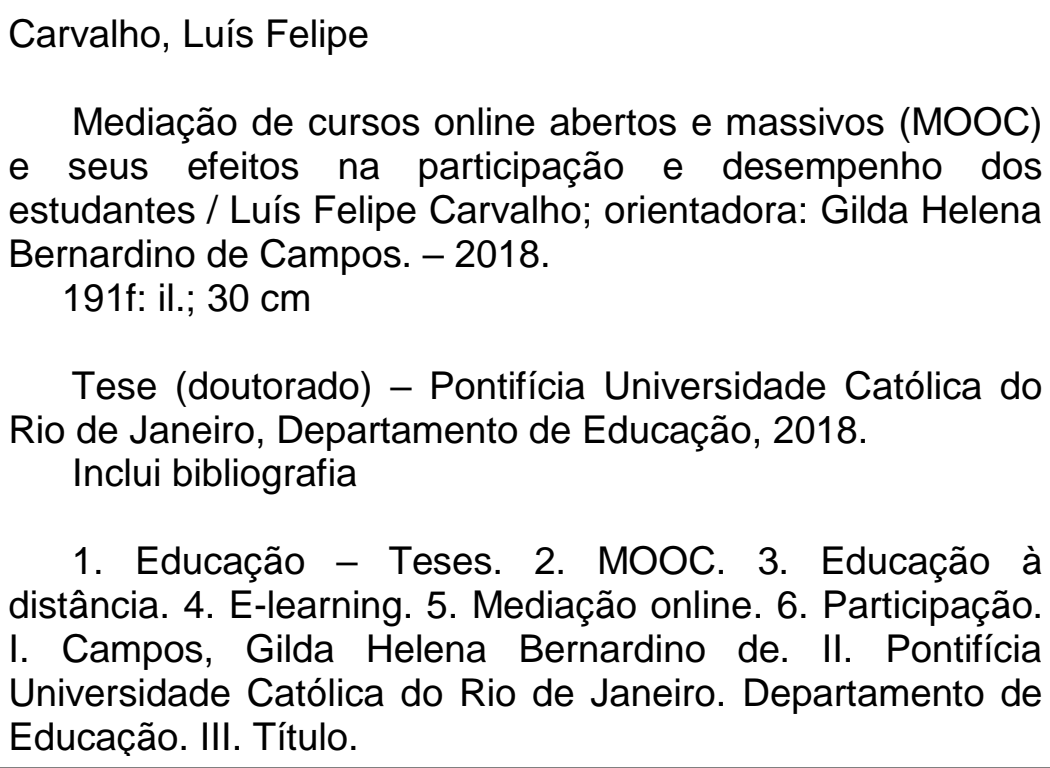

1. Educação - Teses. 2. MOOC. 3. Educação à distância. 4. E-learning. 5. Mediação online. 6. Participação. I. Campos, Gilda Helena Bernardino de. II. Pontifícia Universidade Católica do Rio de Janeiro. Departamento de Educação. III. Título. 
Para todos aqueles com dificuldade de aprendizagem e atenção. Através da persistência e resiliência você pode se superar. 


\section{Agradecimentos}

A minha orientadora Prof. Gilda, por toda paciência, estímulo, gentileza e confiança depositada em mim. Reconheço sua coragem ao aceitar me orientar em um tema tão novo e ainda pouco explorado no meio acadêmico.

A minha esposa e filhos, que me apoiaram durante toda esta jornada de quatro anos. Eles abriram mão de muitas coisas para eu conseguir chegar ao final.

Aos meus pais e irmãos por terem me apoiado durante esta longa trajetória da educação formal, especialmente durante os momentos mais difíceis durante o ensino médio.

A minha avó Altair Maia de Carvalho, que se dedicou como professora do ensino fundamental em escolas públicas durante toda sua vida. Em uma família onde poucos tiveram acesso à educação escolar no passado, ela foi um ponto de referência para as gerações seguintes. Sou o primeiro membro da família a concluir um doutorado.

Aos meus colegas Felipe Araújo e David Gibbin por terem colaborado na criação do primeiro MOOC na PUC-Rio, sem nada pedir em troca, somente pela satisfação de poder compartilhar o conhecimento com mais pessoas. 


\section{Resumo}

Carvalho, Luis Felipe; Campos, Gilda Helena Bernardino de. Mediação de cursos online abertos e massivos (MOOC) e seus efeitos na participação e desempenho dos estudantes. Rio de Janeiro, 2018. 191p. Tese de Doutorado - Departamento de Educação, Pontifícia Universidade Católica do Rio de Janeiro.

Conduzimos uma pesquisa de campo a partir de um curso online aberto e massivo (MOOC), realizado no último trimestre de 2017, utilizando o ambiente virtual de aprendizagem da PUC-Rio. A partir da experiência com este curso, estudamos a dinâmica de participação dos alunos nas atividades pedagógicas e os efeitos no desempenho, baseados em exames de avaliação. Também estudamos a interação entre os participantes do curso a partir dos fóruns de discussão com o apoio de um mediador. Um grupo de controle sem a participação do mediador foi criado, para viabilizar um estudo comparativo de resultados. Além disso, ampliamos o estudo para avaliar também possíveis efeitos do mediador no comportamento dos alunos nas atividades didáticas do curso. Ao final traçamos um perfil dos alunos do curso e realizamos comparações com cursos MOOC realizados por outras instituições de ensino.

\section{Palavras-chave}

MOOC; educação à distância; e-learning; conectivismo; cursos online; Mediação; Participação. 


\section{Abstract}

Carvalho, Luis Felipe; Campos, Gilda Helena Bernardino de. (Advisor). Mediation of massive online open courses (MOOC) and their effects on student participation and performance. Rio de Janeiro, 2018. 191p. Tese de Doutorado - Departamento de Educação, Pontifícia Universidade Católica do Rio de Janeiro.

We conducted a field study from a massive open online course (MOOC), held in the last quarter of 2017, using PUC-Rio's virtual learning platform. From the experience with this course, we studied the dynamics of students' participation on the course activities and the effects on performance in the evaluation. We also studied the interaction between course participants on discussion forums with the support of a mediator. A control group without the participation of the mediator was created, to make feasible a comparative study of results. In addition, we extended the study to evaluate possible mediator effects on student behavior in other course activities. At the end we draw a profile of the students of the course and compared with MOOC courses conducted by other educational institutions.

\section{Keywords}

MOOC; distance education; e-learning; conectivism; online courses; mediation; participation. 


\section{Sumário}

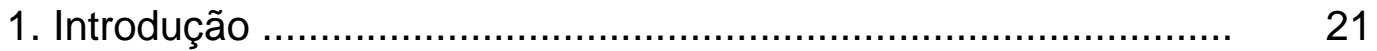

1.1. Objetivo da Pesquisa .................................................... 22

1.2. Contribuições da Tese .................................................. 22

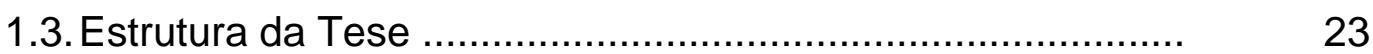

2. Origem e fundamentos dos MOOC .......................................... 24

2.1. A transformação digital ...................................................... 24

2.2. Teoria do Conectivismo ....................................................... 27

2.3. Informação e Conhecimento .................................................. 28

2.4. Críticas ao Conectivismo ......................................................... 33

2.5. A criação do primeiro $\mathrm{MOOC}$............................................... 35

3. A evolução na primeira década dos MOOC ………………......... 40

3.1. A difusão dos MOOC como tecnologia ................................... 41

3.2. Classificação taxonômica dos MOOC ...................................... 47

3.3. Análise crítica dos resultados ............................................... 62

4. Participação e Mediação em Cursos Online ................................. 69

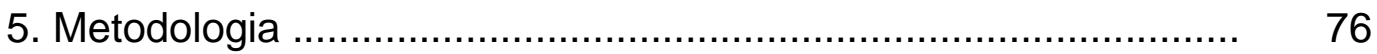

5.1. Linha de Pesquisa ...........................................................

5.2. Universo e Amostra .......................................................... 76

5.3. Pesquisa de Campo ....................................................... 79

5.4. Coleta de Dados, Harmonização e Seleção das Variáveis ....... 90

5.5. Tratamento de Dados ...................................................... 96

5.6. Limitações do Método ........................................................... 99

6. Análise dos Resultados …................................................. 101

6.1. Estatísticas descritivas do curso .......................................... 101 
6.2. Teste de normalidade das variáveis numéricas ...................... 113

6.3. Análise da Influência de Grupo nas atividades do curso .......... 118

6.4. Influência de Grupo nos exames de cada módulo ................... 138

6.5. Verificação Efeitos características demográficas ................... 142

6.6. Análise da correlação entre idade e atividades do curso ........ 163

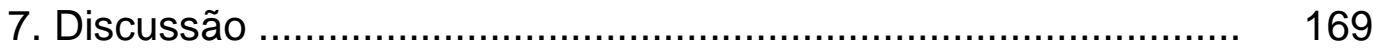

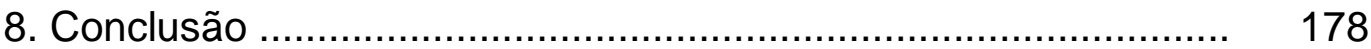

9. Referências bibliográficas 181

$\begin{array}{ll}\text { Anexos } & 185\end{array}$ 


\section{Lista de figuras}

Figura 1 - Resource One Newsletter, no. 2, 1974, Community Memory records, Box 12, Folder 16, Catalog 102734421

Figura 2 - Community Memory localizado na Leopold's Records, em Berkeley, na Califórnia

Figura 3 - Conhecimento através da nova lógica de conexão. Autoria própria

Figura 4 - Modelo do Hype Cycle proposto pela Gartner e suas cinco fases

Figura 5 - Eventos esperados em cada fase do Hype Cycle

Figura 6 - Estágio atual de maturação da tecnologia dos MOOC segundo o Hype Cycle

Figura 7 - Escala classificatória dos MOOC segundo Yousef (2014)

Figura 8 - Padrões Estudantis emergentes em xMOOC de acordo com diferentes graus de engajamento nos cursos (Ho et al., 2014)

Figura 9 - Ferramenta de Feedback para 0 Mediador Habermasiano nos fóruns de discussão do curso

Figura 10 - Matrículas em cursos regulamentados totalmente a distância ou semipresenciais, segundo o censo EAD.BR (em números absolutos)

Figura 11 - Matrículas em cursos livres, segundo o censo EAD.BR (em números absolutos)

Figura 12 - Tela de Matrícula no MOOC de Introdução às Criptomoedas no site da CCE/PUC-Rio

Figura 13 - Tela da página inicial do curso de Introdução às Criptomoedas

Figura 14 - Tela com o termo de consentimento livre e esclarecido para pesquisa online

Figura 15 - Tela com as opções de resposta ao termo da pesquisa

Figura 16 - Tela principal do curso após escolha do Termo de participação na pesquisa

Figura 17 - Exemplo de formato de uma videoaula do curso

Figura 18 - Tela referente ao enunciado do Fórum de discussão do módulo 1

Figura 19 - Tela de exemplo com trecho da discussão no Fórum do módulo 1. 
Figura 20 - Chamada para a Facebook Live dentro de página de grupo fechado no Facebook

Figura 21 - Impressão de Tela de trecho da terceira transmissão ao vivo com os professores do curso (Facebook Live)

Figura 22 - Impressão de tela com trecho do exame de avaliação do módulo 1 do curso

Figura 23 - Impressão de Tela referente a um extrato da base de dados do MOOC de Introdução às Criptomoedas

Figura 24 - Processo de Coleta de Dados

Figura 25 - Primeira página do Livro com o material de estudos do Módulo 1 do curso

Figura 26 - Gráfico de Barras com a distribuição dos participantes do curso por região geográfica

Figura 27 - Distribuição dos participantes do curso por sexo

Figura 28 - Percentual dos alunos que visualizaram o Cronograma do Curso

Figura 29 - Percentual dos alunos que visualizaram o programa do curso

Figura 30 - Histograma de distribuição de idade dos participantes no curso

Figura 31 - Distribuição percentual dos participantes do curso por agrupamento ( $\mathrm{C}$ - Controle, $\mathrm{H}$ - Mediador)

Figura 32 - Boxplot da distribuição dos agrupamentos por frequência de idade

Figura 33 - Tempo total de visualização e tempo média de visualização das videoaulas do curso (Fonte: Vimeo)

Figura 34 - Distribuição de visualizações de videoaulas do curso por data (Fonte: Vimeo)

Figura 35 - Número de "plays" por videoaula do curso (Fonte: Vimeo)

Figura 36 - Número de impressões das videoaulas por dispositivo (Fonte: Vimeo)

Figura 37 - Diferença entre os grupos no total de postagens no fórum de discussão do módulo 1

Figura 38 - Diferença entre os grupos no total de postagens no fórum de discussão do módulo 2

Figura 39 - Diferença entre os grupos no total de postagens no fórum de discussão do módulo 3

Figura 40 - Diferença entre os grupos no total de postagens no fórum de discussão dos módulo1, 2 e 3 
Figura 41 - Diferença entre os grupos no tamanho das postagens no fórum de discussão do módulo 1.

Figura 42 - Diferença entre os grupos no tamanho das postagens no fórum de discussão do módulo 2

Figura 43 - Diferença entre os grupos no tamanho das postagens no fórum de discussão do módulo 3

Figura 44 - Diferença entre os grupos no tamanho das postagens nos fóruns de discussão dos módulos 1, 2 e 3

Figura 45 - Diferença entre os grupos na quantidade de visualizações das videoaulas no Módulo 1

Figura 46 - Diferença entre os grupos na quantidade de visualizações das videoaulas no Módulo 2

Figura 47 - Diferença entre os grupos na quantidade de visualizações das videoaulas no Módulo 3

Figura 48 - Diferença entre os grupos na quantidade de visualizações das videoaulas em todo curso

Figura 49 - Diferença entre os grupos na aprovação nos exames de avaliação

Figura 50 - Diferença na frequência de resultados do exame do módulo 1 por grupo

Figura 51 - Diferença na frequência de resultados do exame do módulo 2 por grupo

Figura 52 - Diferença na frequência de resultados do exame do módulo 3 por grupo

Figura 53 - Diferença na quantidade de postagens nos fóruns de discussão entre os sexos

Figura 54 - Diferença na quantidade de postagens entre participantes com grau de formação superior e ensino médio .........

Figura 55 - Diferença na quantidade de postagens por região geográfica

Figura 56 - Diferença entre sexos no tamanho total das postagens nos fóruns de discussão dos Módulos 1, 2 e 3

Figura 57 - Diferença no tamanho das postagens entre os alunos do ensino superior e alunos do ensino médio

Figura 58 - Diferença no tamanho das postagens entre as regiões geográficas dos participantes do curso

Figura 59 - Diferença entre sexos com relação à quantidade de visualizações das videoaulas ...

Figura 60 - Diferença na quantidade de visualizações de videoaulas por grau de formação do aluno do curso

Figura 61 - Diferença visualização total por região geográfica 
Figura 62 - Diferença entre sexos nos exames de avaliação dos

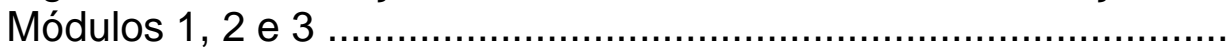

Figura 63 - Diferenças nas aprovações entre graus de formação dos alunos

Figura 64 - Diferenças nas aprovações entre regiões geográficas dos alunos

Figura 65 - Mapeamento de Interações do Mediador ao longo do período do curso

Figura 66 - Análise de Funil do Curso

Figura 67 - Quantidade de Alunos Matriculados nos cursos MOOC das Universidades de Harvard e MIT (2012-2016). Fonte: CHUANG and HO, 2016 


\section{Lista de quadros}

Quadro 1 - Cronograma de Acontecimentos (Evidência de passagem pelos eventos previstos no Hype Cycle) - Período 2008 a 2013

Quadro 2 - Cronograma de Acontecimentos (Evidência de passagem pelos eventos previstos no Hype Cycle) - Período 2013 a 2017

Quadro 3 - Comparação das características dos cMOOC e XMOOC (Smith e Eng, 2013)

Quadro 4 - Comparação adaptada das características dos cMOOC e XMOOC. Desenvolvimento próprio dos autores

Quadro 5 - Lista completa de meta dados (SCHNEIDER, 2013) ....

Quadro 6 - Lista de Elementos do Ambiente Interativo de Aprendizagem (SCHNEIDER, 2013)

Quadro 7 - Proposta de Campos para Meta-Dados. Autoria própria

Quadro 8 - Proposta de Campos para Classificação Taxonômica de MOOC. Autoria própria

Quadro 9 - Exemplos de classificação taxonômica baseados em produtos de MOOC existentes

Quadro 10 - Classificação Taxonômica do MOOC de Introdução às Criptomoedas

Quadro 11 - Lista de Variáveis Demográficas selecionadas para pesquisa

Quadro 12 - Variável de Agrupamento

Quadro 13 - Lista de Variáveis associadas a atividades do participante no curso

Quadro 14 - Estatísticas Participação dos alunos nos fóruns de discussão

Quadro 15 - Estatísticas de tamanho das postagens nos fóruns dos módulos 1, 2 e 3

Quadro 16 - Estatísticas de visualização de vídeos para os módulos 1,2 e 3

Quadro 17 - Estatísticas de aprovações nas avaliações dos Módulos 1 , 2 e 3

Quadro 18 - Teste Qui-quadrado para normalidade das variáveis de participação nos fóruns do curso 
Quadro 19 - Teste KS para normalidade das variáveis de participação nos fóruns do curso

Quadro 20 - Teste Qui-quadrado para normalidade das variáveis de tamanho de postagem nos fóruns do curso

Quadro 21 - Teste KS para normalidade das variáveis de participação nas variáveis de tamanho das postagens nos fóruns do curso

Quadro 22 - Teste Qui-quadrado para normalidade das variáveis de visualização das videoaulas do curso

Quadro 23 - Teste KS para normalidade das variáveis de visualização das videoaulas do curso

Quadro 24 - Teste Qui-quadrado para normalidade das variáveis de avaliação do curso

Quadro 25 - Teste KS para normalidade das variáveis de avaliação do curso

Quadro 26 - Estatísticas descritivas para o número de postagens por grupo no fórum de discussão do módulo 1

Quadro 27 - Resultados da ANOVA para os efeitos de grupo nas postagens no fórum de discussão do módulo 1

Quadro 28 - Resultados do Teste t para participação por grupo no fórum de discussão do módulo 1

Quadro 29 - Estatísticas descritivas para o número de postagens por grupo no fórum de discussão do módulo 2

Quadro 30 - Resultados da ANOVA para os efeitos de grupo nas postagens no fórum de discussão do módulo 2

Quadro 31 - Resultados do Teste t para participação por grupo no fórum de discussão do módulo 2

Quadro 32 - Estatísticas descritivas para o número de postagens por grupo no fórum de discussão do módulo 3

Quadro 33 - Resultados da ANOVA para os efeitos de grupo nas postagens no fórum de discussão do módulo 3

Quadro 34 - Resultados do Teste t para participação por grupo no fórum de discussão do módulo 3

Quadro 35 - Estatísticas descritivas para o número total de postagens por grupo nos fóruns de discussão dos módulos 1, 2 e 3

Quadro 36 - Resultados da ANOVA para os efeitos de grupo nas postagens nos fóruns de discussão dos módulos 1, 2 e 3

Quadro 37 - Resultados do Teste t para participação por grupo no fórum de discussão dos módulos 1, 2 e 3

Quadro 38 - Estatísticas descritivas para o tamanho das postagens por grupo no fórum de discussão do módulo 1. 
Quadro 39 - Resultados da ANOVA para os efeitos de grupo no tamanho das postagens no fórum de discussão do módulo 1 ..........

Quadro 40 - Resultados do Teste t para tamanho das postagens por grupo no fórum de discussão do módulo 1

Quadro 41 - Estatísticas descritivas para o tamanho das postagens por grupo no fórum de discussão do módulo 2

Quadro 42 - Resultados da ANOVA para os efeitos de grupo no tamanho das postagens no fórum de discussão do módulo 2

Quadro 43 - Resultados do Teste t para tamanho das postagens por grupo no fórum de discussão do módulo 2

Quadro 44 - Estatísticas descritivas para o tamanho das postagens por grupo no fórum de discussão do módulo 3

Quadro 45 - Resultados da ANOVA para os efeitos de grupo no tamanho das postagens no fórum de discussão do módulo 3 ..........

Quadro 46 - Resultados do Teste t para tamanho das postagens por grupo no fórum de discussão do módulo 3

Quadro 47 - Estatísticas descritivas para o tamanho das postagens por grupo nos fórum de discussão dos módulos 1,2 e 3

Quadro 48 - Resultados da ANOVA para os efeitos de grupo no tamanho das postagens nos fóruns de discussão dos módulos 1, 2 e 3

Quadro 49 - Resultados do Teste t para tamanho das postagens por grupo nos fóruns de discussão dos módulos 1, 2 e 3

Quadro 50 - Estatísticas descritivas para quantidade de visualizações das videoaulas no Módulo 1

Quadro 51 - Resultados da ANOVA para os efeitos de grupo na quantidade de visualizações das videoaulas no Módulo 1

Quadro 52 - Estatísticas descritivas para quantidade de visualizações das videoaulas no Módulo 2

Quadro 53 - Resultados da ANOVA para os efeitos de grupo na quantidade de visualizações das videoaulas no Módulo 2

Quadro 54 - Estatísticas descritivas para quantidade de visualizações das videoaulas no Módulo 3

Quadro 55 - Resultados da ANOVA para os efeitos de grupo na quantidade de visualizações das videoaulas no Módulo 3

Quadro 56 - Estatísticas descritivas para quantidade de visualizações total das videoaulas em todo curso

Quadro 57 - Resultados da ANOVA para os efeitos de grupo na quantidade de visualizações das videoaulas em todo curso

Quadro 58 - Estatísticas descritivas para aprovações nos exames de avaliação 
Quadro 59 - Resultados da ANOVA para aprovações nos exames

de avaliação

Quadro 60 - Tabela de Frequência de resultado nos exames dos grupos na avaliação do Módulo 1

Quadro 61 - Tabela de coeficientes de associação para os resultados dos grupos nos exames dos grupos na avaliação do Módulo 1

Quadro 62 - Teste qui-quadrado para associação dos resultados nos exames por grupos na avaliação do Módulo 1

Quadro 63 - Tabela de Frequência de resultado nos exames dos grupos na avaliação do Módulo 2

Quadro 64 - Tabela de coeficientes de associação para os resultados dos grupos nos exames dos grupos na avaliação do Módulo 2

Quadro 65 - Teste qui-quadrado para associação dos resultados nos exames por grupos na avaliação do Módulo 2

Quadro 66 - Tabela de Frequência de resultado nos exames dos grupos na avaliação do Módulo 3

Quadro 67 - Tabela de coeficientes de associação para os resultados dos grupos nos exames dos grupos na avaliação do Módulo 3

Quadro 68 - Teste qui-quadrado para associação dos resultados nos exames por grupos na avaliação do Módulo 3

Quadro 69 - Média de postagens por sexo nos fóruns dos módulos 1,2 e 3

Quadro 70 - Resultados da ANOVA para as diferenças na quantidade postagens por sexo nos fóruns de discussão para os módulos 1 , 2 e 3

Quadro 71 - Teste de homogeneidade da variância na quantidade total de postagens nos fóruns do curso por sexo

Quadro 72 - Média de postagens nos módulos 1, 2 e 3 por grau de formação

Quadro 73 - Resultados da ANOVA para efeito do grau de formação na quantidade de postagens nos fóruns dos Módulos 1 , 2 e 3

Quadro 74 - Teste de homogeneidade da variância na quantidade total de postagens nos fóruns do curso por grau de formação .........

Quadro 75 - Média de postagem nos fóruns dos Módulos 1, 2 e 3 por região geográfica

Quadro 76 - Resultado da ANOVA para diferenças na quantidade de postagens nos fóruns dos Módulos 1, 2 e 3 por região geográfica 
Quadro 77 - Teste de homogeneidade da variância na quantidade total de postagens nos fóruns do curso por região

Quadro 78 - Teste não paramétrico de Kruskal Wallis para diferenças entre as regiões

Quadro 79 - Tamanho Médio das postagens por sexo nos fóruns dos módulos 1,2 e 3

Quadro 80 - Resultados da ANOVA para o tamanho das postagens por sexo nos fóruns de discussão para os módulos 1, 2 e 3

Quadro 81 - Teste de homogeneidade da variância do tamanho total das postagens nos fóruns do curso por sexo

Quadro 82 - Resultado do Teste de Kruskal Wallis para diferença entre sexos no tamanho das postagens

Quadro 83 - Tamanho médio das postagens nos fóruns dos Módulos 1, 2 e 3 de acordo com o grau de formação

Quadro 84 - Resultado da ANOVA para diferença entre tamanho das postagens dos alunos do ensino superior e ensino médio ........

Quadro 85 - Teste de homogeneidade da variância do tamanho total das postagens nos fóruns do curso por grau de formação ......

Quadro 86 - Tamanho médio das postagens nos fóruns dos Módulos 1, 2 e 3 por região geográfica do participante

Quadro 87 - Resultado da ANOVA para diferença entre tamanho das postagens nos fóruns por região geográfica do participante ....

Quadro 88 - Teste de homogeneidade da variância do tamanho total das postagens nos fóruns do curso por região geográfica do participante

Quadro 89 - Resultado do Teste de Kruskal Wallis para diferença entre regiões geográficas dos participantes no tamanho das postagens

Quadro 90 - Total de visualizações de videoaulas por sexo nos módulos 1,2 e 3

Quadro 91 - Resultados da ANOVA para o efeito das diferenças de sexo no total de visualizações de videoaulas nos módulos 1, 2 e 3

Quadro 92 - Teste de homogeneidade da variância da quantidade de visualizações das videoaulas do curso por sexo

Quadro 93 - Média de visualização de videoaulas dos Módulos 1, 2 e 3 por grau de formação

Quadro 94 - Resultados da ANOVA para diferenças por grau de formação no total de visualizações das videoaulas dos Módulos 1 , 2 e 3 
Quadro 95 - Teste de homogeneidade da variância da quantidade de visualizações das videoaulas do curso por grau de formação ....

Quadro 96 - Média de visualização das videoaulas dos Módulos 1, 2 e 3 por região geográfica

Quadro 97 - Resultados das ANOVA para as diferenças na visualização total de vídeos do curso por região geográfica

Quadro 98 - Teste de homogeneidade da variância da quantidade de visualizações das videoaulas do curso por região geográfica do participante

Quadro 99 - Média de aprovação por sexo nos exames de avaliação do curso para os Módulos 1, 2 e 3

Quadro 100 - Resultados da ANOVA para o efeito de sexo aprovação nos exames nos módulos 1,2 e 3

Quadro 101 - Teste de homogeneidade da variância das aprovações nos exames de avaliação do curso por sexo

Quadro 102 - Média de aprovação nos exames de avaliação do curso por grau de formação do aluno

Quadro 103 - Resultados da ANOVA para diferença nos resultados de avaliação do curso por grau de formação do aluno ..

Quadro 104 - Teste de homogeneidade da variância das aprovações nos exames de avaliação do curso por grau de formação

Quadro 105 - Média de aprovações nos exames dos Módulos 1, 2 e 3 por região geográfica

Quadro 106 - Resultados da ANOVA para diferenças de aprovação nos exames de avaliação do curso por região geográfica

Quadro 107 - Teste de homogeneidade da variância das aprovações nos exames de avaliação do curso por região geográfica do participante

Quadro 108 - Coeficiente Beta de Correlação entre idade e quantidade de postagens nos fóruns de discussão do curso

Quadro 109 - Modelo de Regressão Linear simples para correção entre idade e quantidade de postagens nos fóruns do curso

Quadro 110 - Análise residual para medida do grau de significância de R2 no Modelo

Quadro 111 - Modelo de Regressão Linear simples para correção entre idade e tamanho de postagens nos fóruns do curso

Quadro 112 - Análise residual para medida do grau de significância de R2 no Modelo

Quadro 113 - Coeficiente Beta de Correlação entre idade e o tamanho das postagens nos fóruns de discussão do curso 
Quadro 114 - Modelo de Regressão Linear simples para correção entre idade a quantidade de visualizações das videoaulas do curso

Quadro 115 - Análise residual para medida do grau de significância de R2 no Modelo

Quadro 116 - Coeficiente Beta de Correlação entre idade e quantidade de visualizações das videoaulas do curso

Quadro 117 - Modelo de Regressão Linear simples para correção entre idade e aprovações nos exames de avaliação do curso .........

Quadro 118 - Análise residual para medida do grau de significância de R2 no Modelo

Quadro 119 - Coeficiente Beta de Correlação entre idade e quantidade de aprovações nos exames do curso

Quadro 120 - Modelo de Regressão Linear simples para correção entre as atividades do curso e aprovações nos exames de avaliação

Quadro 121 - Coeficiente Beta de Correlação entre as atividades do curso e quantidade de aprovações nos exames de avaliação ...

Quadro 122 - Modelo de regressão Stepwise com as duas variáveis de predição (postagens e visualizações de vídeo) 


\section{1 \\ Introdução}

A propagação da internet em larga escala ${ }^{1}$ e o acesso quase que universal aos dispositivos pessoais de comunicação ${ }^{2}$ abre uma janela para experimentação com novas formas de pedagogia na era digital. Os cursos online abertos e massivos, mais conhecidos pelo acrônimo de MOOC (Massive Online Open Courses), são uma das vertentes de maior experimentação e repercussão midiática dos últimos anos no campo da educação.

A partir de uma proposta de educação acessível e de qualidade para as massas, os cursos MOOC aparecem como uma nova forma de aprendizagem sem fronteiras e sem barreiras para a sociedade moderna, cada vez mais conectada na grande rede de comunicação global. Porém, ao observar experiências passadas com cursos abertos no formato MOOC, é fácil perceber que ainda existe um longo caminho até que esta promessa seja totalmente cumprida. Pesquisas na área identificaram que os MOOC sofrem sérios problemas de retenção, mesmo ao considerar indivíduos que demonstram pleno interesse de completar os cursos. A estimativa é que a taxa de alunos que efetivamente completa os cursos seja inferior a 15\% (HEW E CHEUNG, 2014; JORDAN, 2015; KOLLER et al., 2013). Além disso, pesquisas também identificam grande variação nos resultados de aprendizagem experimentados por participantes de MOOC (WATSON, KIM E WATSON, 2016; XING et al., 2016). A partir destes estudos emergem questionamentos sobre a eficácia desta modalidade de curso e o quanto os estudantes podem efetivamente se beneficiar destes ambientes de aprendizagem online (LOIZZO e ERTMER, 2016).

Passada pouco mais de uma década desde que o termo MOOC foi cunhado, a partir de um curso experimental na Universidade de Manitoba, no Canadá, já é possível observar com um pouco mais de parcimônia e olhar crítico o funcionamento desta modalidade de educação online. Depois de atravessar uma fase de grandes expectativas, seguida de uma fase de grandes desilusões, os

\footnotetext{
${ }^{1}$ Fonte: Consulta página da Internet World Stats realizada na data de 03/06/2017 (http://www.internetworldstats.com/stats.htm)

${ }^{2}$ Fontes: Relatório Cisco (http://www.cisco.com/c/en/us/solutions/collateral/serviceprovider/visual-networking-index-vni/mobile-white-paper-c11-520862.html) e Relatório Ericsson (http://www.ericsson.com/res/docs/2015/ericsson-mobility-report-june-2015.pdf)
} 
MOOC caminham para uma fase de desenvolvimento incremental. Talvez um dia este formato de curso possa ser visto como uma importante inovação na área de educação.

\section{1}

\section{Objetivo da Pesquisa}

O objetivo desta pesquisa é realizar um estudo de campo para melhor compreender o funcionamento de um MOOC, atribuindo um olhar especial para a questão da mediação no ambiente de aprendizagem e os efeitos na participação no curso.

As análises dos MOOC realizadas até o presente momento na literatura especializada, apontam para um alto índice de abandono dos cursos e baixo grau de participação. Isso é algo antagônico à proposta inicial, na época de criação dos primeiros MOOC, que era justamente de promover um modelo de educação acessível e de qualidade para todos, apesar da larga escala de distribuição dos cursos. Portanto, senso comum, altos índices de abandono e baixa interatividade em um curso, não parecem ser critérios favoráveis.

A partir de uma perspectiva de pesquisa exploratória e quantitativa, vamos analisar os resultados de um MOOC realizado na PUC-Rio com 1.200 alunos matriculados, majoritariamente brasileiros, com duração de cerca de um mês e ocorrido no final do ano de 2017.

\section{2}

\section{Contribuições da Tese}

A partir dos resultados desta pesquisa, apontamos as seguintes contribuições para o campo da pedagogia:

- Análise e descrição dos resultados de um MOOC regional, realizado no Brasil, em Português;

- Descrição do perfil dos participantes de cursos MOOC;

- Análise dos efeitos na participação dos alunos em fóruns de discussão a partir da inserção de um mediador; 
- Apontamentos de práticas bem-sucedidas na criação de MOOC, tanto na perspectiva do ambiente de aprendizagem online quanto das práticas de condução do curso;

- Proposta de classificação taxonômica dos MOOC;

- Discussão sobre novas ferramentas de comunicação que aumentem a participação de alunos em MOOC e reduzam as taxas de evasão e fracasso nos cursos;

- Análise de métricas de participação e desempenho em MOOC.

\section{3}

\section{Estrutura da Tese}

A Tese está estruturada em oito capítulos, que cobrem desde a fundamentação teórica até a discussão dos resultados obtidos na pesquisa. Logo após a introdução do trabalho, o capítulo 2 explica detalhadamente os MOOC, começando pela sua origem a partir da concepção da Teoria do Conectivismo até a criação dos primeiros MOOC. Em seguida, no capítulo 3, é feita uma análise dos MOOC a partir da perspectiva de inovação, propondo uma classificação taxonômica e fechando com uma análise crítica dos resultados obtidos até o momento com os MOOC. No capítulo 4, apresentamos uma discussão sobre os conceitos de participação e mediação em cursos online. Os capítulos 5 e 6 apresentam a metodologia de pesquisa e a análise dos resultados obtidos a partir dos dados coletados no ambiente do curso. O capítulo 7 propõe uma discussão acerca dos resultados obtidos e resgata a teoria inicialmente proposta como fundamentação. No capítulo final de conclusão, é feita uma revisão do trabalho e das oportunidades de pesquisa futura a partir dos resultados obtidos. 


\section{Origem e fundamentos dos MOOC}

\section{1}

\section{A transformação digital}

Em 1972, surgiu em Berkeley, na Califórnia, o primeiro serviço público computadorizado de troca de mensagens, mais conhecido como BBS (Bulletin Board System), que na tradução literal para o português, seria um sistema de quadro de avisos. O serviço, criado por Lee Felsenstein, Efrem Lipkin, Ken Colstad, Jude Milhon e Mark Szpakowski, foi chamado de Community Memory. Ele rodava em três computadores compartilhados por uma comunidade de geeks ${ }^{3}$, na sua maioria estudantes de ciência da computação.

Os fundadores do Community Memory tinham uma aderência grande a esta nova ideia de unir tecnologia e colaboração na troca de informações, pois estavam, em diferentes níveis, envolvidos com um movimento amplo de contracultura que ocorria na Universidade de Berkeley chamado de Free Speech Movement ${ }^{4}$. Em 1972 eles se associaram a uma organização da sociedade civil, sem fins lucrativos, chamada de Resource One, cuja lema era "Tecnologia para as Pessoas".

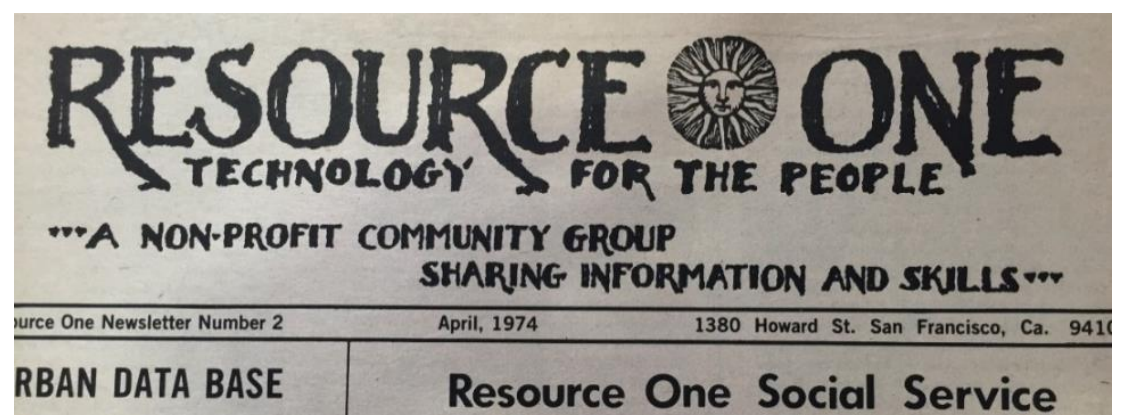

Figura 1 - Resource One Newsletter, no. 2, 1974, Community Memory records, Box 12, Folder 16, Catalog 102734421

\footnotetext{
${ }^{3}$ A palavra geek é um adjetivo que caracteriza uma pessoa com grande interesse por tecnologia, por tudo que é novo. Os geeks desenvolvem aplicativos, softwares, jogos de computador, por exemplo. Atualmente a palavra tem sido usada de forma mais ampla para caracterizar qualquer indivíduo que se torna um especialista em assuntos que são do seu interesse.

${ }^{4}$ O Free Speech Movement (FSM) foi originalmente um protesto que ocorreu no ano de 1964 (calendário acadêmico 64-65) no Campus da Universidade da Califórnia, Berkeley, sob a liderança informal dos estudantes Mario Savio, Jack Weinberg, Michael Rossman, Brian Turner, Bettina Aptheker, Steve Weissman, Art Goldberg, Jackie Goldberg, dentre outros. Em um protesto inédito, os estudantes insistiam que a administração da universidade acabasse com a proibição de atividades políticas no Campus e aceitasse o direito de Liberdade de expressão dos estudantes e a liberdade acadêmica.
} 
O primeiro terminal conectado ao Community Memory era um ASR-33 que ficava ao final de uma escada que conduzia para a entrada de uma loja de discos chamada Leopold's Records, em Berkeley. O terminal ficava ao lado de um movimentado quadro de avisos onde pessoas deixavam diversas mensagens como anúncios de quartos para alugar, livros para vender, aulas particulares, dentre outras mensagens típicas de um quadro de avisos. A ideia inicial do terminal era replicar o quadro de avisos no formato digital. Qualquer um podia deixar mensagens e anexar palavras-chave a elas. Desta forma, outras pessoas podiam encontrar estas mensagens digitando estas palavras-chave. A linha de comunicação entre São Francisco e Berkeley rodava a uma velocidade que permitia a transmissão de dez caracteres por segundo (mais precisamente 110 baud). Algo impensável no mundo atual. Equivaleria a cerca de um minuto para transmitir uma simples página de texto, se fosse este o caso.

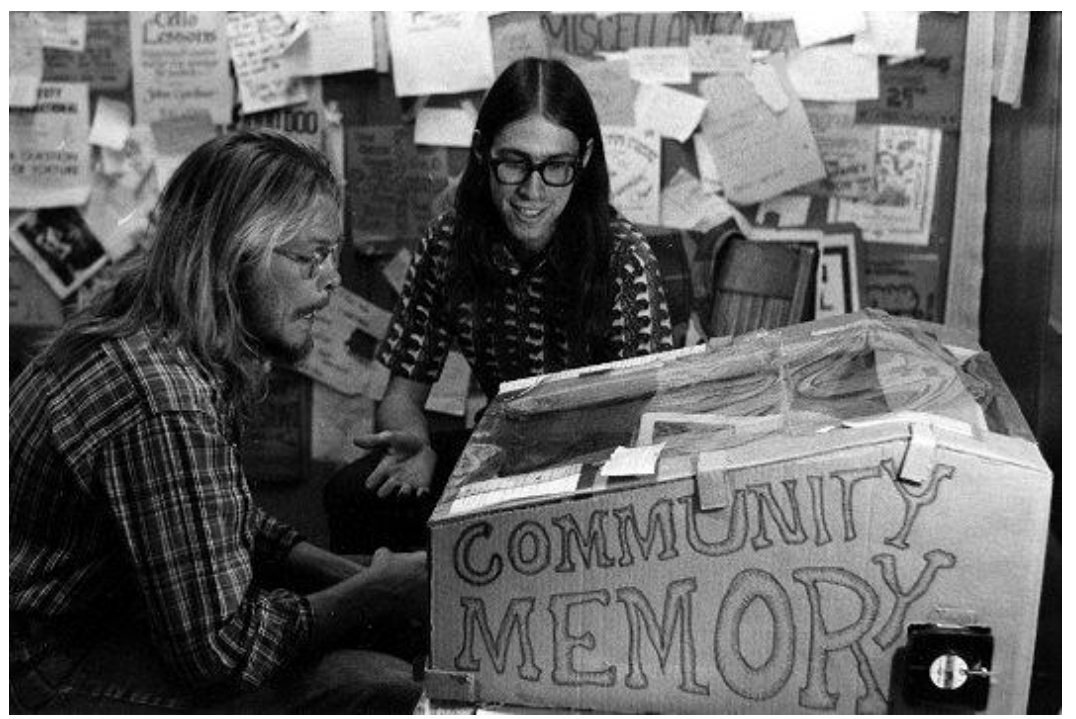

Figura 2 - Community Memory localizado na Leopold's Records, em Berkeley, na Califórnia

Em 2018, passaram-se mais de quarenta e quatro anos desde esta primeira experiência pública aberta de compartilhamento de informação digital. O progresso tecnológico neste período viabilizou a troca de informação em escala infinitamente maior. $\mathrm{O}$ mesmo intervalo de tempo que naquela época era necessário para transferir dez caracteres ou aproximadamente um byte, hoje transmite facilmente cem milhões de bytes. O terminal, quase que único na ocasião, hoje está acessível para mais de três bilhões de pessoas através de diversos dispositivos que acessam a Internet em todo mundo - grande parte deles móveis e todo tempo presentes na vida destas pessoas. 
Esta massificação dos dispositivos de transmissão de conteúdo digital interativo abriu uma porta para introdução de novas experiências relevantes na área de educação (GARRISON, 2003). As fronteiras entre os métodos de instrução tradicionais e métodos online vêm progressivamente sendo reduzidas (YOUNG, 2002). Fatores críticos como acessibilidade, disponibilidade e falta de engajamento, colocados inicialmente como entraves (WILLIAMS, 2002), dão sinais claros que estão sendo resolvidos (MEANS et. al., 2004). O acesso a aparatos digitais e infraestrutura criaram uma cultura de compartilhamento da informação, interatividade e engajamento social na rede. As discussões realizadas nos mais diversos tipos de fóruns públicos na internet são registros permanentes e contínuos no tempo. A experiência de aprendizado híbrida surge como um método educacional que se apoia em ferramentas digitais e presenciais (BONK, 2006). Os MOOC são um exemplo concreto desta confluência tecnológica.

Como um primeiro passo no estudo da fundamentação dos MOOC, propomos o estudo da chamada "Teoria do Conectivismo", elaborada pelo pesquisador canadense George Siemens, há cerca de uma década atrás (SIEMENS, 2005). As ideias propostas por Siemens neste artigo podem ser consideradas uma primeira tentativa de criação de um arcabouço teórico que originou os MOOC. Apesar das ideias do conectivismo de Siemens não terem evoluído muito mais do que a produção deste trabalho, não há como estudar esta modalidade de curso sem entender as ideias do conectivismo, que serviram como uma fagulha inicial. O pano de fundo para o surgimento desta teoria foi descrito nesta introdução. O Community Memory foi o embrião para esta nova forma de lidar com a informação e o conhecimento de maneira colaborativa. A internet é a estrutura tecnológica que viabilizou a sua reprodução em massa e os smartphones foram os aparatos que deram mobilidade e instantaneidade a este acesso. A união destas tecnologias estimulou o instinto de compartilhamento de ideias entre as pessoas e o seu senso de interatividade. A Teoria do Conectivismo (SIEMENS, 2005) se propõe a olhar o processo de aprendizagem sob este novo paradigma, que começou a dar os primeiros sinais de vida na década de 60 , veio ao mundo na década de 90 e atinge sua maturidade na segunda década do século XXI. Nada disso estava previsto quando as tradicionais teorias de aprendizagem foram escritas. Isso abre margem para a discussão promovida com a proposta Conectivista. Estamos realmente diante de uma nova realidade que alterou de 
maneira estrutural a forma como aprendemos? Ou estaríamos diante de mais um tipo de mídia que foi tão impactante quanto as anteriores, como a imprensa escrita e a televisão? Precisamos realmente de uma nova teoria para explicar a forma como aprendemos ou podemos analisar a nova realidade a partir das teorias existentes como o construtivismo? Seria o conectivismo realmente uma nova teoria ou somente um vestígio do passado?

\section{2 \\ Teoria do Conectivismo}

A Teoria do Conectivismo traz na sua essência a ideia de que o conhecimento está distribuído em redes de conexão. Portanto, o processo de aprendizagem consiste na habilidade de construir e acessar estas redes de conexão (SIEMENS, 2005). Segundo o Conectivismo, o conhecimento não é somente o conteúdo armazenado e processado no cérebro de um indivíduo. Ele é também a soma dos aplicativos disponíveis em dispositivos externos como os smartphones, as conexões com as pessoas acessíveis em listas de contatos, as páginas disponíveis para consulta na internet, dentre muitas outras formas. A rede em si torna-se o conhecimento (SIEMENS, 2005). Neste cenário, a educação é entendida como um processo de formação de conexões com o objetivo de acessar o conhecimento distribuído.

Siemens apresenta uma crítica às teorias de aprendizagem tradicionais baseadas no cognitivismo, behaviorismo e construtivismo. Segundo ele, estas teorias foram criadas antes da era digital, caracterizada pela abundância e instantaneidade das informações (SIEMENS, 2005). O cenário anterior era muito diferente do atual, pois adotava uma premissa que o acesso à informação era, de certa forma, um recurso escasso. Com a era digital, emergiu um novo mundo de acesso à informação instantânea de forma abundante e até mesmo excessiva, fazendo com que os mecanismos de filtragem se tornassem um fator crítico no processo de aprendizagem (BARBER et al., 2013). Para o conectivismo, tem mais valor identificar os meios de aquisição do conhecimento do que o esforço para internalização do conhecimento no indivíduo (SIEMENS, 2005). Essa é uma mudança de paradigma radical e as competências individuais derivadas desta mudança apontam especialmente para o desenvolvimento de habilidades de 
formar conexões com as fontes de conhecimento. Desta forma, Siemens (2005) entende e propõe que o principal objetivo do processo de aprendizagem deixa de ser a obtenção do conhecimento propriamente dito e passa a ser a busca pela forma de conexão com o conhecimento distribuído.

Outro elemento utilizado por Siemens (2005) para justificar a criação de uma nova teoria é uma ideia em comum que todas as teorias anteriores compartilhavam. Essa ideia seria a de que o conhecimento somente ocorre dentro de um indivíduo. A Teoria do Conectivismo lança a ideia de conhecimento acontecendo fora do indivíduo - por exemplo, o conhecimento que é armazenado e manipulado por artefatos tecnológicos. Esta ideia é muito parecida com a conceito de Externalismo Ativo (CLARK \& CHALMERS, 1998), na qual objetos espalhados pelo ambiente de inserção do indivíduo funcionam como parte da sua mente. Essa ideia, um tanto controversa, foi um dos principais pontos de ataque da crítica ao Conectivismo, especialmente com a chegada das mais novas tecnologias de aprendizagem de máquina e os avanços no campo da inteligência artificial. Entretanto, fica claro que estes novos campos, apesar dos longos anos investidos em pesquisa, ainda estão nos seus primórdios e caracterizam-se por serem áreas de exploração nas fronteiras de descoberta da ciência.

\section{3 \\ Informação e Conhecimento}

Como se pode notar na introdução deste capítulo, Siemens (2005) pode se mostrar um tanto ambíguo ao tratar os conceitos de informação e conhecimento. Não que haja um consenso para definição destes conceitos, mas a argumentação de Siemens parece não fazer sentido em alguns momentos, por talvez não ter trabalhado previamente a distinção entre informação e conhecimento.

Até o momento só criamos mecanismos para acesso instantâneo e resgate das informações da nossa mente, em nossa rede de neurônios, presente em nosso cérebro. Com a nova lógica de conexão, podemos criar mecanismos também de acesso instantâneo a outras redes, sejam elas residentes em pessoas ou dispositivos. A capacidade de saber mais é aumentada pela adição de novos nós em nossa rede pessoal e pelo aprendizado de como usá-los adequadamente. Por outro lado, a consciência continua individual e o julgamento final de valor é do indivíduo. 
Se o conhecimento for entendido como um produto da consciência, então deveríamos mudar a argumentação anterior e substituir a palavra conhecimento por informação. A fim de alinhar os conceitos utilizados neste trabalho, estamos considerando como conhecimento a informação que pode ser acessada, resgatada de forma instantânea pelo sujeito e submetida à sua interpretação. Portanto, uma informação em um livro pode ou não ser considerada conhecimento. Se o sujeito tiver capacidade de acessar este livro, na página certa, de forma instantânea, e ainda conseguir gerar compreensão e julgamento de valor para esta informação, a consideramos como conhecimento. O mesmo vale para a mente. Uma informação que um dia foi armazenada na sua memória e ainda está acessível e compreensível de maneira instantânea, pode ser considerada conhecimento. Entretanto, não é possível se dizer que conhece algo que não se consegue resgatar da memória e submeter ao julgamento da própria mente. Por exemplo, o sujeito estuda o código penal para fazer uma prova de direito. Ele leu todos os artigos do código. Entretanto, na hora da prova ele não lembrou de um determinado artigo e não conseguiu responder à questão. Por mais que tenha esta informação na cabeça, ele não conseguiu acessá-la na hora que precisava e, portanto, neste momento, aquela informação não podia ser considerada conhecimento. Por outro lado, ela também não poderia ser considerada como inexistente, porque está registrada na mente do indivíduo, que por sua vez não consegue acessá-la naquele momento. Logo após a prova, passada a pressão do exame e todos os ruídos que o impediram de acessar aquela informação, o candidato lembra do artigo em questão. Neste momento, aquela informação está acessível e ele entende seu significado, sabe como usá-la, tem aplicação prática. Esta informação é elevada à categoria de conhecimento. $\mathrm{O}$ sujeito pode afirmar - "eu conheço este artigo".

A visão que aqui propomos para o conhecimento, com fins de eliminar a ambiguidade de Siemens neste tópico, inclui a dimensão temporal. "Eu conheço agora, mas não posso garantir que conhecerei amanhã”. Sob esta perspectiva, fazemos uma proposta de compreensão do conceito de conhecimento a partir de três características-chave: 
a. Acessível (sei onde está e como chegar até ela, neste instante)

b. Resgatável (consigo ver seu conteúdo e submetê-lo ao meu raciocínio)

c. Compreensível (posso gerar significados úteis a partir dela)

Uma mesma informação pode ou não se tornar conhecimento dependendo do momento em que um sujeito realize o acesso. Este é o aspecto temporal do conhecimento. Se em determinado momento o sujeito tem a demanda de uma informação e consegue ao mesmo tempo encontrá-la (acessível), submetê-la ao seu raciocínio (resgatável) e gerar significados úteis a partir dela (compreensível), classificamos esta informação, para efeitos deste trabalho, como conhecimento. O esquema abaixo ilustra estas possíveis configurações. Procure observá-la da direita para a esquerda.

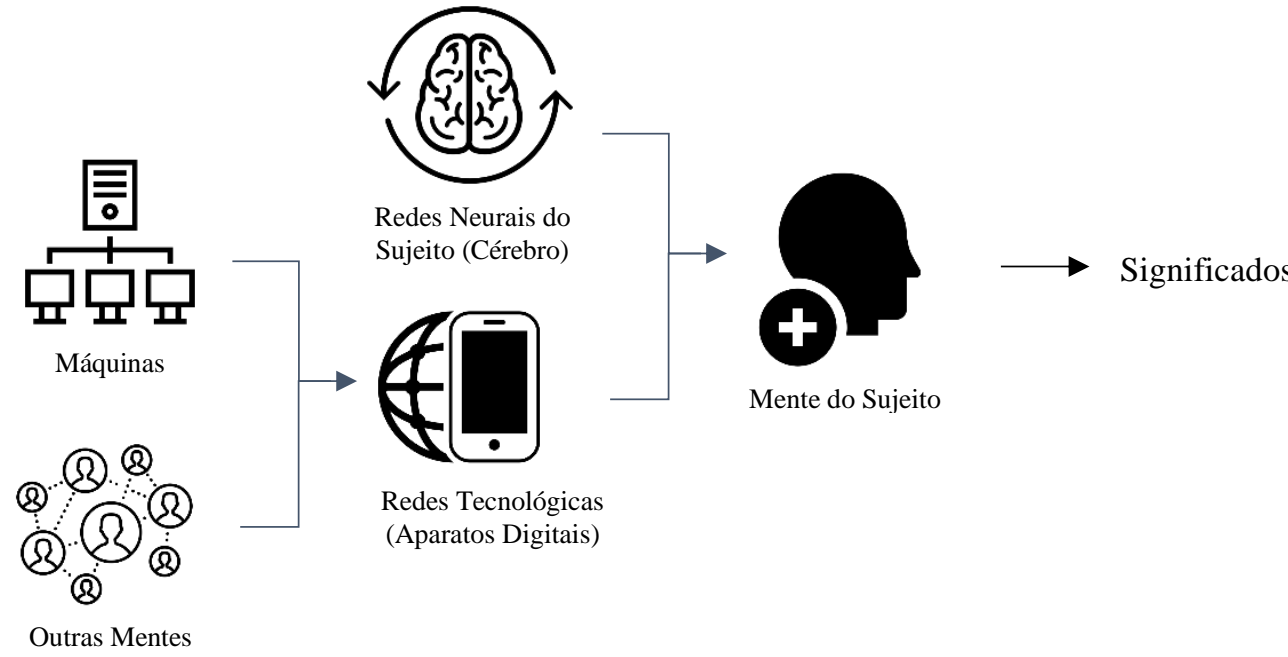

Figura 3 - Conhecimento através da nova lógica de conexão. Autoria própria.

Adotando como verdadeiras estas três caraterísticas-chaves do conhecimento, podemos aplicá-las à teoria do Conectivismo e testar sua validade no que tange a ideia de conhecimento armazenado em dispositivos externos. Tomemos um exemplo trivial, como uma simples receita de um bolo. Como um primeiro cenário fictício, pensemos em um confeiteiro que recebe uma encomenda para fazer um bolo de chocolate. Ele tem a receita completa em sua mente e consegue chegar a ela instantaneamente (acessível). Também consegue visualizar mentalmente a receita e submeter cada elemento ao seu raciocínio (resgatável), gerando significados práticos para sua intenção inicial de fazer um bolo 
(compreensível). Desta forma, podemos inferir que a receita de bolo de chocolate é um conhecimento que ele tem.

No segundo cenário, pensemos no mesmo confeiteiro recebendo uma encomenda para um bolo de uma fruta exótica da região andina, chamada Chirimoya. Estamos no ano de 1960 e o confeiteiro não conhece esta receita, porém o cliente que encomendou o bolo também informou que a receita existe em um livro de receitas raras, localizado na biblioteca pública. Apesar de existir esta informação, não podemos dizer que o confeiteiro a conhece. Ele sabe como chegar a ela, portanto, podemos afirmar que está acessível, mas não instantaneamente. Transformar esta informação em conhecimento dependerá do deslocamento do cozinheiro até a biblioteca pública e isso iria infringir a restrição temporal. Depois de visitar a biblioteca e memorizar a receita, ou talvez levando o livro emprestado, o cozinheiro terá transformado a informação em conhecimento.

Pensemos agora o mesmo caso citado no parágrafo anterior, mas em um outro momento, mais precisamente no ano de 2017. O confeiteiro recebe o pedido e imediatamente digita o nome da receita em seu smartphone conectado à internet. Em menos de cinco segundos ele tem a receita completa na tela de seu aparelho. Segundo os critérios que definimos, esta informação está acessível, resgatável e compreensível. Será que não podemos considerá-la conhecimento? Será que podemos dizer que o cozinheiro não conhecia a receita simplesmente porque ela não estava previamente em sua mente? Quanto de conhecimento conseguimos armazenar em nossas mentes e quanto de espaço cada uma destas peças ocupa em nosso cérebro? Será que a simples ligação entre um dispositivo digital portátil e o acesso instantâneo à informação demandada não poderiam ser elevados ao status de um tipo de conhecimento não internalizado na memória do sujeito? Qual a diferença entre eles? O tempo de acesso é quase o mesmo - memória versus dispositivo externo. $\mathrm{O}$ que falar de falhas no momento em que tentamos buscar as informações no nosso cérebro? Seria correto afirmar que o confeiteiro conhece a receita do bolo de chocolate caso ele a tivesse esquecido? E quando lembrasse, a informação muda de condição?

Considerando que os aparatos digitais interconectados estão cada vez mais presentes em nossas vidas, não poderíamos considera-los como uma extensão do nosso cérebro? Pelo simples fato de existirem, mudamos nosso comportamento e deixamos de armazenar certas informações em nossas mentes, como por exemplo 
os contatos de telefone. Transferimos para as máquinas certas habilidades cognitivas importantes como as de cálculo, mas confiamos tanto no acesso instantâneo a estes dispositivos que na maioria dos casos não consideramos mais a hipótese de retornar este conhecimento para o nosso cérebro. O que vemos agora é uma expansão ainda maior destas oportunidades de conexão, se considerarmos a disponibilidade permanente de acesso à internet através dos dispositivos móveis, importando cada vez menos a nossa localização.

O que pensar então sobre outras aplicações não tão triviais, como os exemplos citados anteriormente, que resgatam uma informação bastante objetiva ("receita de bolo")? Seria possível atribuir a um dispositivo externo uma parte da nossa capacidade de julgamento? Até que ponto nosso histórico de decisões e escolhas não pode ser base para criação de padrões? Recorrendo a um exemplo prático, podemos observar certo grau de acerto nos algoritmos de predição de palavras aplicados aos teclados de dispositivos móveis. Seu nível de acerto nas sugestões da próxima palavra que será digitada é bastante grande. A teoria do Conectivismo considera as teorias de caos e incertezas como uma das vias para predição de características de julgamento inerentes ao nosso processo de raciocínio e escolha.

Uma outra questão referente ao aspecto temporal levantada por Siemens (2005) é a questão da validade do conhecimento. Esse aspecto deixa ainda mais relevante a decisão de armazenar ou não o conhecimento em nosso cérebro, que poderíamos aqui chamar de um dispositivo interno, para efeitos comparativos com os dispositivos externos ao nosso corpo. O tempo de obsolescência do conhecimento está sendo reduzido de forma inversamente proporcional ao aumento da capacidade de processamento e armazenamento. $\mathrm{O}$ conhecimento que antes demorava décadas para caducar foi encurtado para meses. Isso está sendo provocado pelo aumento da capacidade humana de conceber, armazenar e compartilhar novas ideias. Isso não é um aumento somente quantitativo, mas também um aumento qualitativo. A produção científica por assim dizer, está em pleno crescimento no aspecto teórico e vemos as consequências em campos práticos como a medicina, a engenharia, a economia, por exemplo. Isso tem provocado um aumento na chamada obsolescência do conhecimento, considerando que o mesmo não é infalível. Como lidar com todo este volume de 
conhecimento que tem enorme valor em termos de história, mas que em termos de prática não faz mais sentido?

É neste novo cenário de hiperconectividade, abundância de informação e rápida obsolescência que a Teoria do Conectivismo é concebida. Segundo o próprio autor, mais importante que a internalização do conhecimento, é a conexão com os canais que levam ao conhecimento (SIEMENS, 2005).

\section{4 \\ Críticas ao Conectivismo}

Como mencionado anteriormente, esta nova abordagem teórica proposta por Siemens tem gerado diversas críticas. As principais, argumentam que o Conectivismo nada mais é do que uma forma de construtivismo social (KOP e HILL, 2008), já preconizada anteriormente na teoria de Vygotsky. Kerr reforça a ideia que esta teoria já apontava para a distinção de conhecimento interno e externo muito antes que qualquer embasamento teórico do Conectivismo (KERR, 2007). Ele apresenta a ideia de descontinuidade radical, que basicamente é o choque de cultura de duas gerações de alunos - uma que nasceu antes da era digital e outra que nasceu nesta era e por natureza, mais conectada. Conforme esta geração conectada for aumentando de proporção, irá naturalmente substituir a geração "papel e caneta", causando fricção nos ambientes atuais de aprendizado tipicamente salas de aula em instituições de ensino. Entretanto, esta mudança de paradigma não garante às contribuições do Conectivismo o tratamento de uma nova teoria da aprendizagem. Verhagen (2006) critica o embasamento filosófico que diferencia a nova teoria das anteriormente existentes. Em sua visão, o entendimento do Conectivismo como uma estrutura de rede para aquisição do conhecimento não é suficiente para formulação de uma nova teoria. Seguindo as críticas de Kerr e Verhagen, Kop propõe um encaixe do Conectivismo no nível pedagógico e curricular, considerando que as ideias apresentadas expressam características da nova geração dos millenials $^{5}$ e o desafio de navegação e filtragem do enorme conteúdo de conhecimento disponível (KOP, 2008).

\footnotetext{
${ }^{5}$ Termo usado para definir a geração nascida depois de 1980, na sua maioria filhos de baby boomers. Também são chamados de geração $\mathrm{Y}$ e sua principal característica é ter crescido usando tecnologia digital e ferramentas interativas de comunicação em massa.
} 
Autores da Psicologia cultural também fazem uma crítica direta ao Conectivismo como teoria de aprendizagem (CLARÀ E BARBERÀ, 2013), argumentando que a concepção de aprendizagem por ela apresentada é inadequada e problemática. Os mesmos propõem a psicologia cultural como arcabouço teórico para explicar o processo de aprendizagem na era digital, estando este totalmente baseado no trabalho de Vygotsky. O campo da Psicologia Cultural, também chamado de Teoria da Atividade Histórico-Cultural (CHAT), segundo Clarà e Barberà, é mais amplo do que o trabalho de Vygotsky, operando no eixo de produção formado pelos autores Vygotsky-Leontiev-GalperinDavydov-Cole-Engeström. Na justificativa das autoras para defender o melhor encaixe desta teoria no contexto da aprendizagem na era digital em relação a teoria do conectivismo, está fixada a ideia de que o conhecimento, identificado como representações, é uma ferramenta psicológica para mediação entre um sujeito e um objeto. Estas representações não estão originalmente localizadas dentro do sujeito - sua origem é externa. Além disso, elas só existem quando estão em uso e, portanto, o conhecimento não é algo que o sujeito tem, mas sim algo que o sujeito utiliza em relação a determinado objeto. Além disso, estas representações estão distribuídas, ou seja, presentes e disponíveis, em comunidades e sistemas de atividades (CLARÀ E BARBERÀ, 2013). Esta ideia não está longe do que é proposto pela teoria do Conectivismo. Na realidade, está alinhada com as ideias de Siemens (2005) e com as ideias do Externalismo Ativo (CLARK \& CHALMERS, 1998), citado anteriormente. O que diferencia então as duas abordagens é que segundo a escola da Psicologia Cultural, a aprendizagem consiste na internalização do uso do conhecimento em relação ao objeto, por parte do sujeito aprendiz. Esta internalização só é possível se o aprendiz tem a oportunidade de usar a representação em conjunto com mediadores dentro da zona de desenvolvimento proximal ${ }^{6}$. Como consequência de sua participação nesta atividade conjunta, ocorre a internalização pelos aprendizes, que finalmente podem usar a representação por si mesmos (CLARÀ E BARBERÀ, 2013).

\footnotetext{
${ }^{6}$ A Zona de Desenvolvimento Proximal, também conhecida pelo acrônimo de ZDP, é um conceito desenvolvido por Vygotsky, definido como "a distância entre o nível de desenvolvimento atual determinado pela resolução independente de problemas e o nível de desenvolvimento potencial determinado pela resolução de problemas sob orientação ou em colaboração com parceiros mais capazes" (Vygotsky, 1987)
} 
Segundo o conectivismo, esta internalização não acontece necessariamente, sendo a questão chave a criação da conexão com a fonte de aprendizagem.

O tubo é mais importante do que o conteúdo que passa dentro do tubo. Nossa habilidade de aprender o que vamos precisar para amanhã é mais importante do que aquilo que sabemos hoje. Um desafio real para qualquer teoria de aprendizagem é o de saber o conhecimento no ponto de aplicação. Quando o conhecimento é necessário, porém não conhecido, a habilidade de plugar nas fontes passa a ser uma habilidade vital. Conforme o conhecimento continua a crescer e se desenvolver, o acesso ao que é necessário é mais importante do que a aquisição do conhecimento pelo aprendiz. (SIEMENS, 2005)

$\mathrm{Na}$ prática, este argumento reflete um ponto crítico, que muitos participantes sentem em cursos MOOC, especialmente aqueles que não tem muita capacidade de autonomia. Sentem-se perdidos, sem direção e sem suporte (KOP, 2011). Isso fica evidenciado em um dos primeiros estudos feitos a partir do curso CCK08, considerado o primeiro MOOC. Nele alunos relataram exatamente este sentimento de estarem perdidos dentro de um ambiente pouco estruturado em termos de currículo (MACKNESS et al., 2010).

\section{5 \\ A criação do primeiro MOOC}

A partir de uma tentativa de explicar e tornar mais tangível a Teoria do Conectivismo, emergiu um novo formato de curso que foi chamado de MOOC acrônimo em inglês das palavras Massive Online Open Courses. Em 2008, George Siemens ${ }^{7}$ e Stephan Downes ${ }^{8}$ lançaram um curso chamado "Connectivism and Connective Knowledge". Este curso explorava a temática do próprio conectivismo e ao mesmo tempo tentava experimentar na prática algumas das ideias deste novo arcabouço teórico, proposto pelos mesmos autores no ano de $2005^{9}$. O curso, que era uma disciplina regular e presencial oferecida na

\footnotetext{
${ }^{7}$ George Siemens é um teórico dos processos de aprendizagem na era digital. Ele é professor assistente no Centro de Educação à Distância na Universidade de Athabasca, no Canadá. Fonte: https://pt.wikipedia.org/wiki/George_Siemens <link acessado em 30 de janeiro de 2018>

${ }^{8}$ Stephen Downes (6 de abril de 1959) é um designer e comentador no campo da aprendizagem utilizando as tecnologias digitais. Downes tem explorado e promovido o uso educacional de computadores e de tecnologias ligadas à Internet desde 1995. Suas ideias podem ser visualizadas no link http://www.downes.ca. Fonte: https://pt.wikipedia.org/wiki/Stephen_Downes < acessado em 30 de janeiro de 2018>

${ }^{9}$ Trata-se aqui do artigo original que propôs a ideia da "Teoria do Conectivismo", referenciado em seção anterior neste trabalho.
} 
universidade de Manitoba com o código CCK08, teve sua matrícula aberta para qualquer interessado em participar, através de uma modalidade online. A adesão externa foi surpreendente e além dos 24 alunos estudantes da universidade matriculados na turma da disciplina, cerca de outras duas mil pessoas se matricularam de forma livre. $\mathrm{O}$ curso aconteceu com uma perspectiva inédita, ainda não experimentada anteriormente. Todo conteúdo do curso foi disponibilizado via Feeds ${ }^{10}$ do tipo RSS e os alunos podiam participar com a sua escolha de ferramentas como discussões mediadas no ambiente virtual de aprendizagem com base a plataforma Moodle, postagens em Blog, jogos em ambientes virtuais e por reuniões online sincronizadas. Diferente de outras experiências de educação online em massa ocorridas anteriormente, existia no CCK08 um conceito de turma, ou seja, de sincronicidade. É importar destacar este aspecto desde já porque isso será alvo de discussão posterior quando tratarmos da classificação dos formatos de MOOC atualmente existentes.

O acrônimo MOOC surge como uma forma de descrever este primeiro experimento. A versão não oficial, porém, mais divulgada e aceita na internet, é que o termo teria sido cunhado por Dave Cornier ${ }^{11}$ durante uma conversa por Skype com George Siemens. Dave, participante da equipe que desenvolvia a estrutura pedagógica do curso, teria espontaneamente, na conversa com Siemens, citado a expressão "Massive Online Open Course" para descrever de forma resumida o que estava acontecendo na experiência do CCK08. Inicialmente este termo e o próprio curso não surtiram muita repercussão na mídia não especializada. Entretanto, nos círculos de educação mais próximos a Siemens e Downes, alguns começaram a enxergar este evento como um marco importante na criação de uma nova era de acesso livre e abundante a educação

\footnotetext{
${ }^{10}$ A sigla RSS tem mais de um significado. Alguns a definem como RDF Site Summary, outros a denominam Really Simple Syndication. Há ainda os que a entendem como Rich Site Summary. RSS é um padrão desenvolvido em linguagem XML que permite aos responsáveis por sites e blogs divulgarem notícias ou novidades destes. Para isso, o link e o resumo daquela notícia (ou a notícia na íntegra) é armazenado em um arquivo de extensão .xml, .rss ou .rdf (é possível utilizar outras extensões). Este arquivo é conhecido como feed ou feed RSS. Uma pessoa interessada em obter as notícias ou as novidades de um site deve incluir o link do feed deste em um programa ou serviço leitor de RSS (também chamado de agregador). Este software (ou serviço, se for um site) tem a função de ler o conteúdo dos feeds que indexa e mostrá-lo em sua interface.

(Fonte: http://www.infowester.com/rss.php)

11 Fonte: http://davecormier.com/edblog/2008/10/02/the-cck08-mooc-connectivism-course-14way/
} 
institucionalizada ${ }^{12}$, que até então estavam restritos a poucos. Nos anos que seguiram o marco inicial dos MOOC, uma quantidade enorme de cursos começou a ser lançada sob esta modalidade. A quantidade de pessoas que se inscreviam nestes cursos também foi aumentando rapidamente, atingindo uma quantidade que não deixava dúvida sobre o termo "Massivo", que representa a primeira letra do acrônimo MOOC. Um dos casos mais conhecidos foi o curso de Inteligência Artificial da Universidade de Stanford, ministrado em 2011 pelo professor Sebastian Thrun ${ }^{13}$. Cerca de 160.000 estudantes de 190 países diferentes se matricularam no curso. A partir daí muitas outras instituições começaram a olhar de forma mais séria para este fenômeno que estava nascendo. Ao mesmo tempo, começou um questionamento quase que paralelo sobre a validade dos MOOC, muito no sentido de eficácia desta nova modalidade de ensino. Um dos principais alvos de crítica passou a ser a taxa de conclusão do curso. No caso do curso de Inteligência Artificial de Stanford, cerca de 22.000 alunos concluíram efetivamente o curso - uma taxa de cerca de $14 \%$ dos inscritos, algo quase que impensável em uma experiência de ensino presencial. O mesmo cenário de baixa conclusão se manteve em outros cursos da época. No curso de Circuitos e Eletrônica do MIT, foram cerca de 155.000 matriculados de 160 países diferentes. Deste total, cerca de 23.000 fizeram o primeiro dever do curso, 9.000 completaram a avaliação intermediária e 7.517 efetivamente concluíram o curso. Ou seja, uma proporção de cerca de $5 \%$ do total inicial de matriculados.

Em estudo mais recente do ano de 2014, Alcorn e Christensen (2014) mostram um panorama dos MOOC existentes que reforça as dúvidas sobre o caráter efetivamente inclusivo deste tipo de modalidade de ensino. Segundo a pesquisa realizada pelos autores, dois terços dos participantes de MOOC se originam em países desenvolvidos, essencialmente dos Estados Unidos e outros

\footnotetext{
${ }^{12}$ Entenda-se por este termo "educação institucionalizada" uma forma de conglomerar a educação, especialmente de ensino superior, oferecida por instituições de ensino. Quando se pensa nas possibilidades de acesso, um dos maiores desafios é a restrição de quantidade de vagas nas turmas. Já existia certamente a oferta de cursos à distância por estas instituições, porém as experiências de interatividade com outros membros da turma e professores era bastante restrita.

${ }^{13}$ Sebastian Thrun é alemão, naturalizado norte-americano, professor da Universidade de Stanford. Ele foi um dos primeiros a experimentar cursos no formato MOOC. A partir desta experiência, fundou uma empresa para explorar uma plataforma própria de MOOC chamada Udacity. Este empreendimento atraiu muitos investidores e apareceu na mídia como um dos principais casos de MOOC. Thrun acabou aparecendo também como um precursor da modalidade MOOC e foi bastante criticado por focar mais no modelo econômico com foco no resultado financeiro do que efetivamente no desenvolvimento de um modelo de aprendizagem que funcionasse.
} 
países integrantes da OECD. Se somados, estes países representam menos de $20 \%$ da população mundial. Eles também levantaram na mesma pesquisa que mais de $80 \%$ dos estudantes eram portadores de diploma de ensino superior, mesmo sendo muitos deles moradores de regiões do mundo onde menos de $10 \%$ da população adulta tem esta formação. Se somarmos isso a um outro dado da pesquisa que atesta que cerca de $70 \%$ dos participantes de MOOC estão empregados, percebese claramente indícios de que a questão de inserção de excluídos ainda é um ponto longe da realidade dos cursos MOOC, até o momento. Considerando que não há pré-requisito para matrícula nestes cursos, que atualmente cerca da metade da população do planeta tem acesso à internet e ainda que uma educação de qualidade está associada a melhores empregos e renda, pode-se questionar porque não houve uma participação maior de um perfil de estudante de regiões onde há menos acesso à educação. Dificuldades com idioma? Grau de complexidade dos cursos? Falta de tempo? Falta de incentivos? Dificuldades associadas a questão de tecnologia e infraestrutura? Qual o ingrediente que falta para que a promessa dos MOOC como um modelo de educação inclusiva mostre mais evidências de estar funcionando?

Talvez ainda seja um pouco cedo para julgar algo conclusivo em relação a eficácia dos MOOC como modalidade de ensino e como via de inclusão para uma educação de qualidade. No momento, o que se pode fazer é dar uma descrição do cenário atual dos MOOC. Tipicamente, as inscrições em um MOOC ficam acima de mil alunos, chegando, em alguns casos extremos, a ultrapassar a barreira de cem mil alunos. O maior registro que se tem até o momento é de cento e oitenta mil alunos (KOLOWICH, 2014). Em termos de incentivos para se cursar um MOOC, as motivações residem em uma das quatro categorias abaixo (BELANGER \& THORNTON, 2013):

- Aprendizagem continuada e entendimento de tópicos específicos, sem uma expectativa específica de completar o curso ou conquistar uma aprovação;

- Diversão, entretenimento, experiência social e estímulo intelectual;

- Conveniência de acesso aos cursos, algumas vezes em conjunto com barreiras à outras opções de educação tradicional; 
- Desejo de explorar ou experimentar um formato de educação no ambiente online.

Grover, Franz, Schneider and Pea (2013) acreditam que o perfil e intenção dos alunos expressa diversos tipos de engajamento, o que seria um subproduto da natureza aberta dos MOOC e do seu caráter de novidade. Baseado na pesquisa dos autores em alguns MOOC, um percentual grande se inscreve no curso com objetivos tão diversos quanto "curiosidade sobre o tópico", "afinar habilidades de trabalho", "diversão" e "desafio". Isso requer uma abordagem customizada no modelo de aprendizagem e significa que as medidas tradicionais de resultado, como a taxa de concluintes, pode não representar de forma precisa o engajamento dos alunos de MOOC. Esse argumento dos autores pode ser um tanto controverso. Seria o mesmo que aceitar em aula um aluno disperso, que vaga de sala em sala observando um certo conteúdo sendo apresentado, mas muito pouco ou nada levando para si. Como atribuir algum tipo de nota ao final do curso? Até que ponto este aluno não atrapalha o restante? Ou será que deveríamos deixar os "curiosos" simplesmente olharem e apostar que existe uma semente positiva sendo plantada neste olhar? Seria ele mais um número que somente ajuda a fortificar o caráter massivo dos MOOC? Se for isso, qual a diferença entre ter uma turma com duas mil pessoas inscritas e engajadas e uma outra turma com cem mil inscritos e noventa e oito mil curiosos? O quanto é desperdiçado com essa massa não ativa na experiência de aprendizagem? (Capacidade de processamento, consumo de energia elétrica, investimento em servidores, funcionalidades de automação implementadas para servir aos grandes números, etc.). 


\title{
A evolução na primeira década dos MOOC
}

\begin{abstract}
"Em 1841, o inventor do quadro negro foi declarado por Josiah F. Bumstead em seu livro "O Quadro Negro na Escola Primária" como "um dos melhores colaboradores da aprendizagem e ciência, se não entre os maiores benfeitores da humanidade" (Krause, 2000). A Educação sempre contou com ferramentas, como lápis, livros e quadros-negros para entregar conteúdo. Atualmente, a lista cresceu e inclui as Tecnologias de Informação e Comunicação como computadores e mais recentemente, as plataformas online como os MOOC". (Smith and Eng, 2013, página)
\end{abstract}

$\mathrm{Na}$ seção anterior fizemos uma breve descrição dos fundamentos dos MOOC, sua ligação com a Teoria do Conectivismo e o primeiro curso experimental que deu origem ao termo. Neste capítulo faremos uma revisão da primeira década dos MOOC, ou seja, o período compreendido entre o lançamento do curso CCK08 por Siemens e Downes em 2008 - considerado o marco inicial dos MOOC - até o presente ano de 2018 quando este trabalho está sendo escrito. Independentemente do que vai se tornar esta tecnologia nos próximos anos, ela certamente está contribuindo fortemente com a inserção das TIC na agenda de instituições públicas e privadas, tanto na esfera governamental quanto do mercado. Um bom exemplo são as sucessivas referências aos MOOC nos últimos relatórios Horizon da New Media Consortium ${ }^{14}$.

Nas universidades, que são uma das categorias institucionais mais atingidas pelos MOOC, a discussão está bastante ativa. Professores, reitores, decanos, pesquisadores, coordenadores e departamentos estão sendo provocados a entender o funcionamento e os efeitos desta nova tecnologia no processo de aprendizagem. Também estão tentando entender as consequências nos seus modelos de organização e planejamento acadêmico, que até o momento são guiados essencialmente pelo sistema de hora aula. Neste sistema, cujas aulas ocorrem tipicamente no formato presencial, um professor ministra uma disciplina para uma turma de algumas dezenas de alunos, em um horário pré-definido, normalmente compatível com a janela de tempo de um semestre.

${ }^{14} \mathrm{O}$ New Media Consortium (NMC) é um consórcio internacional não lucrativo, formado por mais de 250 faculdades, universidades, museus, empresas e outras organizações focadas em aprendizagem contínua e dedicadas e explorar o uso de novas mídias e tecnologias. As instituições membros da NMC estão localizadas na maior parte dos estados Norte-Americanos, Canadá, Europa, América Latina, Ásia e Austrália. O relatório Horizon é um dos produtos da NMC, através da sua iniciativa Horizon Project, que tem o objetivo de analisar novas tecnologias emergentes aplicadas no contexto de educação. 
No ensino fundamental e médio, que formam a base da pirâmide da educação formal, a discussão ao redor da aplicação das TIC no modelo de aprendizagem se torna ainda mais complexa por se tratar de crianças e adolescentes ainda em formação. Alguns colégios ${ }^{15}$ já se arriscam a trabalhar na inserção de tecnologias que acabaram emergindo a partir das experiências com MOOC, como é o caso da aprendizagem híbrida e do ensino adaptativo. Estas iniciativas, algumas vezes adotadas por gestores escolares sob o rótulo de "o futuro que chegou na sala de aula", ainda se provam insipientes ao analisar os resultados práticos desta aplicação. Ainda parece ser muito cedo para dar a palavra final no julgamento da eficácia das novas tecnologias digitais na educação, especialmente os MOOC que são alvo deste trabalho.

Este capítulo está estruturado em três tópicos de análise. O primeiro faz uma análise da difusão dos MOOC como uma tecnologia educacional. Para isso usaremos o Gartner Hype Cycle, que é um framework de análise de evolução tecnológica. No segundo tópico, discutimos uma forma de classificação tipológica, que consiga trazer critérios para melhor definição da enorme quantidade de cursos ofertados em todo mundo como MOOC. No terceiro e último tópico deste capítulo, fazemos uma análise crítica dos resultados atingidos até o momento nesta primeira década, que pode ser olhada como uma espécie de fase de experimentação com esta nova e emergente tecnologia educacional.

\section{1}

\section{A difusão dos MOOC como tecnologia}

Um recurso que aqui utilizamos para medir o grau de evolução dos MOOC é o conceito de análise de ciclo de vida. Considerando que as tecnologias apresentam um ciclo que vai desde o seu nascimento até a sua obsolescência, saber em que estágio se encontra a tecnologia em questão pode ser uma informação relevante tanto para interpretar o que aconteceu desde o nascimento da tecnologia até o presente momento, quanto para fazer inferências sobre o futuro da mesma. No caso específico desta pesquisa, a análise do ciclo de vida mostrou-se

\footnotetext{
${ }^{15}$ Um exemplo aqui considerado são as parcerias realizadas entre a Khan Academy e algumas escolas piloto na Califórnia. Mas informações podem ser encontradas no link abaixo: https://www.sri.com/sites/default/files/publications/khan-academy-implementation-report-201404-15.pdf
} 
particularmente interessante por se tratar de uma tecnologia considerada emergente e com alto grau de incerteza. Como veremos mais adiante, a escolha por se realizar uma pesquisa exploratória está ligada ao estágio de maturação da tecnologia no seu ciclo de vida.

Existem diversas metodologias para análise de ciclo de vida de novas tecnologias. Seguiremos aqui com uma metodologia identificada como o Hype Cycle, desenvolvida pelo Grupo Gartner ${ }^{16}$. Esta metodologia foi desenvolvida para representar a maturidade, adoção e aplicação social de novas tecnologias da informação. Ela cruza essencialmente duas variáveis para traçar uma curva de evolução da tecnologia, que segundo a metodologia da Gartner, é uma espécie de padrão, quando se olha para novas tecnologias emergentes. A primeira variável é o tempo e a segunda a visibilidade. Por isso o título "Hype", que é aplicado no sentido de visibilidade de uma nova tecnologia no mercado. As variações na intensidade da visibilidade da tecnologia, por sua vez, promovem alterações nos padrões de adoção e aplicação da tecnologia, formando assim uma curva de maturação, que se torna útil para análise e decisões práticas em relação a tecnologia em questão.

O Hype Cycle, certamente não explora de forma detalhada todos os estágios do ciclo de vida de uma nova tecnologia. Isso fica evidente ao se perceber que as fases nele incorporadas, que serão descritas mais à frente, se concentram nos momentos iniciais de adoção - ou seja, o nascimento da tecnologia. Estas fases não tratam, por exemplo, da questão da substituição da tecnologia e sua eventual obsolescência. Para se analisar o ciclo completo, incluindo as fases finais de adoção, recomendamos uma composição do Hype Cycle com a metodologia desenvolvida por Everet Rogers (2010) para a Difusão de Inovações. No caso dos MOOC, por se tratar de uma tecnologia muito recente e ser o alvo deste estudo, focaremos nos estágios iniciais de maturação, descritos de forma bastante ilustrativa no "Hype Cycle" da Gartner.

Apresentando a metodologia propriamente dita, mostramos a seguir uma visualização do Hype Cycle e, posteriormente, uma descrição das expectativas em relação a tecnologia, ante o grau de visibilidade em cada estágio da curva de maturação.

16 O Grupo Gartner é uma firma de pesquisa e consultoria focada na área de tecnologia da informação, fundada em 1979 nos Estados Unidos. Atualmente com presença global, o grupo emprega mais de 7.000 pessoas, sendo que grande parte delas dedicas a área de pesquisa. O Hype Cycle é uma metodologia desenvolvida pela Gartner para representar graficamente os estágios de maturidade, adoção e aplicação social de tecnologias específicas. 


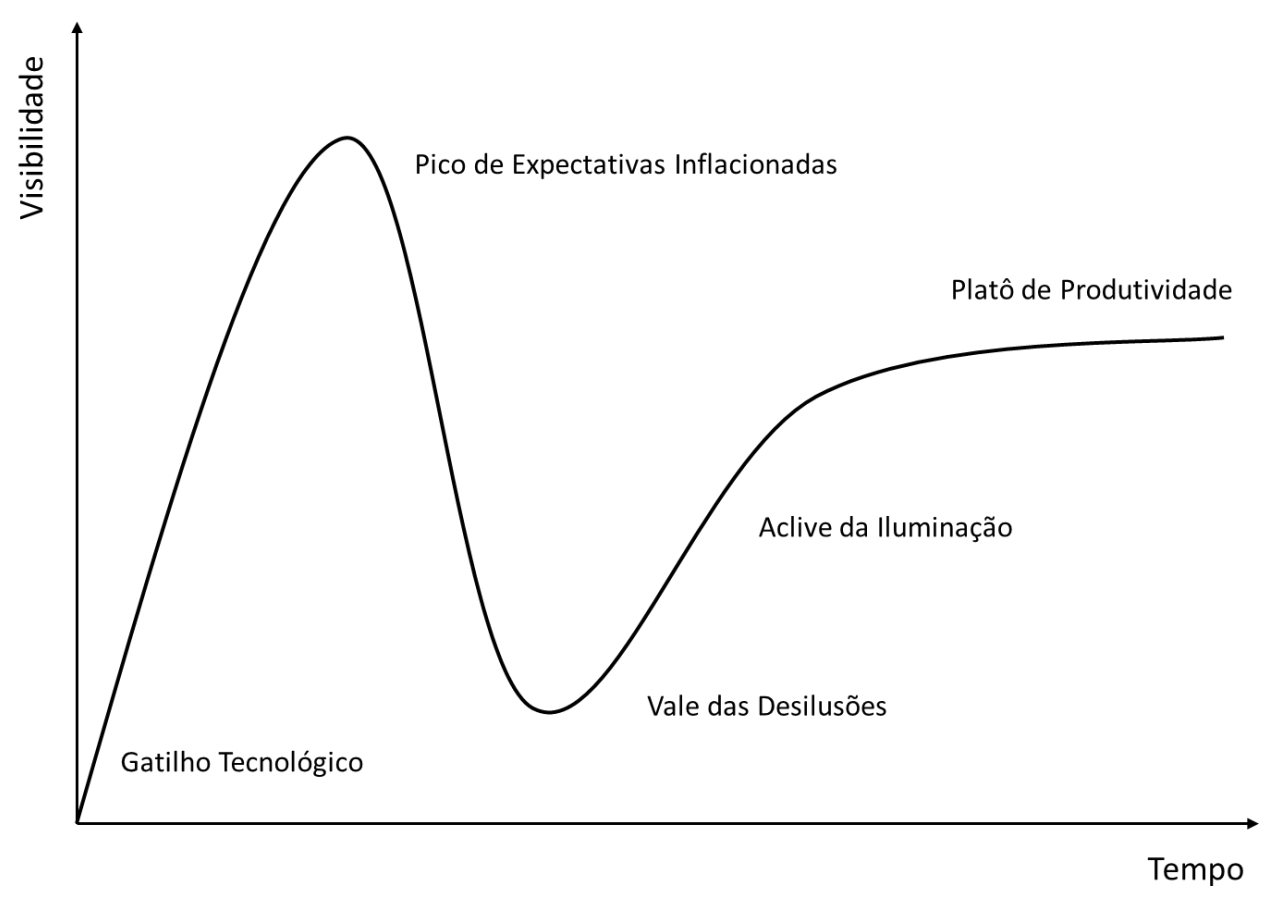

Figura 4 - Modelo do Hype Cycle proposto pela Gartner e suas cinco fases

O gráfico é dividido em cinco fases que caracterizam o ciclo de vida de uma nova tecnologia, até atingir um estágio de difusão. Cabe ressaltar que nem todas as tecnologias conseguem efetivamente atingir um estágio de difusão e se caracterizarem assim como uma inovação. Existem riscos neste processo, mas neste trabalho não nos cabe analisar os riscos de falha no processo de difusão dos MOOC. Porém, se a tecnologia MOOC caminhar na linha da difusão, segundo o "Hype Cycle", ela passará pelas seguintes fases:

1. Gatilho Tecnológico: uma potencial tecnologia inovadora inicia o ciclo. Provas de conceito e casos de sucesso disparam um gatilho de publicidade na mídia. Ainda não existe produtos bem desenvolvidos e a viabilidade econômica ainda não é comprovada.

2. Pico de Expectativas Inflacionadas: A publicidade inicial produz mais casos de sucesso - frequentemente acompanhados de falhas também. Algumas empresas começam a aparecer, mas não muitas.

3. Vale das Desilusões: Os interesses começam a minguar conforme os experimentos e implantações começam a falhar nas suas entregas. Os produtores da tecnologia saem ou falham. Os investimentos continuam somente se os fornecedores que sobreviverem melhorarem seus produtos para a satisfação dos adotantes iniciais.

4. Aclive da Iluminação: Mais opções aparecem de como a tecnologia pode ser benéfica. Elas começam a se cristalizar e a serem efetivamente 
compreendidas. Novos fornecedores percebem incentivos e produtos de segunda e terceiras geração começam a aparecer. Mais empreendimentos financiam experimentos piloto. As empresas conservadoras permanecem cautelosas.

5. Platô de Produtividade: Adoção começa a decolar e se populariza. Critérios para avaliar a viabilidade dos fornecedores são definidos de forma mais clara. A aplicação da tecnologia de forma mais ampla no mercado e a sua relevância estão claramente valendo a pena.

A Gartner aponta ainda alguns eventos que normalmente acontecem em cada um dos estágios. Estes eventos, além de preditivos, também servem de evidência do estágio de maturação da tecnologia. Ou seja, servem como um localizador de posição para a tecnologia na linha do tempo. A figura a seguir mostra o posicionamento dos eventos genéricos, que são por eles identificados como "expectativas", no sentido que: "espera-se que isso aconteça, neste momento".

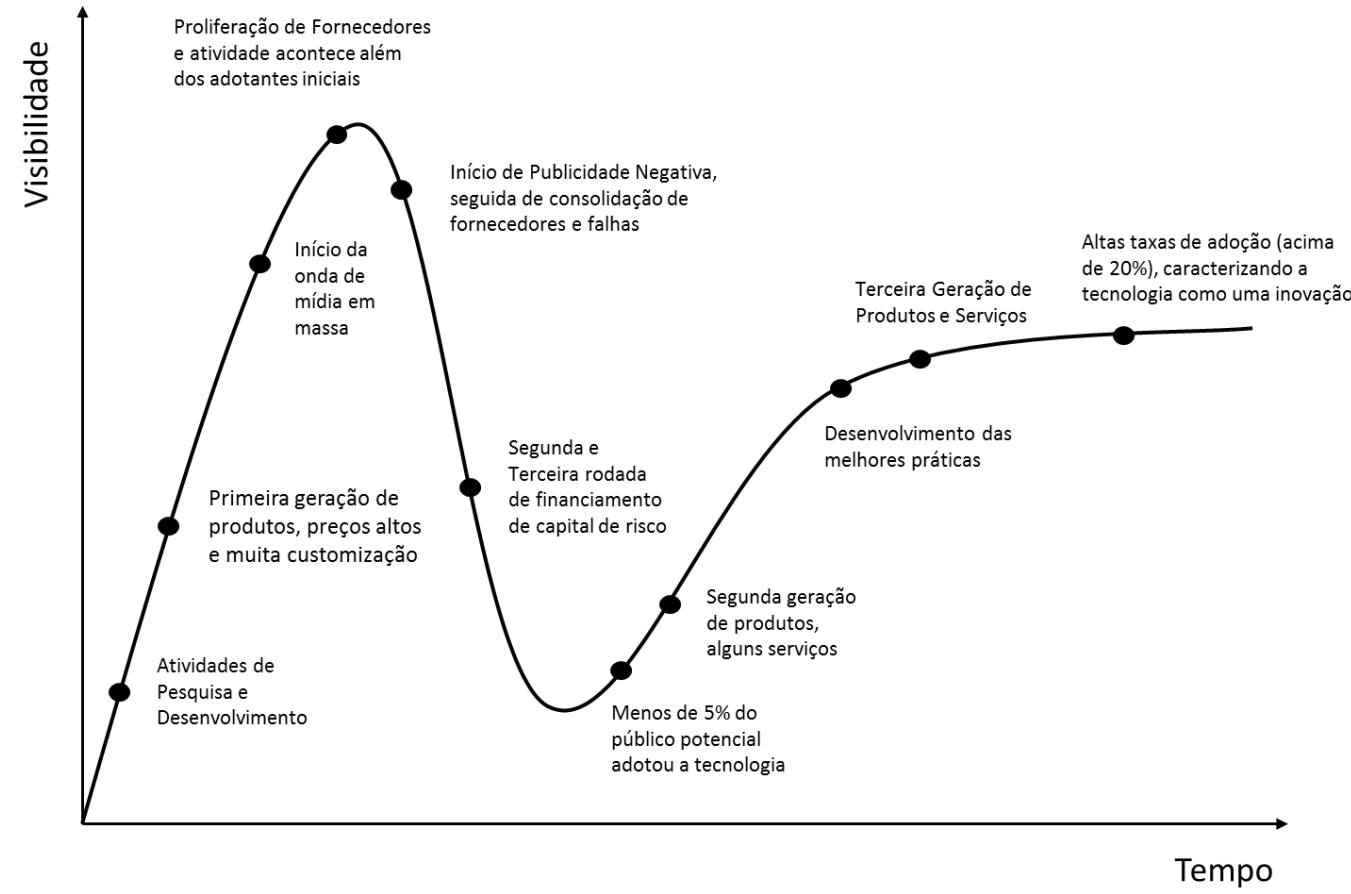

Figura 5 - Eventos esperados em cada fase do Hype Cycle 
Façamos então uma análise dos MOOC a partir do "Hype Cycle". Esperase aqui encontrar os eventos previstos dentro do intervalo de tempo entre os anos de 2008 e 2017, que marca o período entre o nascimento dos MOOC com o curso de Siemens e Downey no ano de 2008 e a presente data quando fazemos a análise, no caso o ano de 2017. O quadro a seguir capta evidências de eventos ocorridos que podemos encontrar em notícias e outras formas de registro (visibilidade). São evidências da passagem pelas fases do "Hype Cycle".

\begin{tabular}{|c|c|c|}
\hline Ano & Expectativa & Evidências \\
\hline $2008-2009$ & $\begin{array}{l}\text { Atividades de Pesquisa e } \\
\text { Desenvolvimento }\end{array}$ & $\begin{array}{l}\text { Siemens e Downey, lançam o primeiro MOOC como um } \\
\text { experimento acadêmico, baseado na Teoria do Conectivismo, que } \\
\text { ambos haviam publicado quatro anos antes. }\end{array}$ \\
\hline 2009-2011 & $\begin{array}{l}\text { Primeira geração de } \\
\text { produtos, preços altos e } \\
\text { muita customização }\end{array}$ & $\begin{array}{l}\text { Universidades de elite começam a lançar seus próprios MOOC } \\
\text { (Harvard, MIT, Stanford, etc.). Altos investimentos para produzir os } \\
\text { cursos. } \\
\text { https://onlinelearninginsights.wordpress.com/tag/costs-of-developing-a-mooc/ }\end{array}$ \\
\hline 2011-2012 & $\begin{array}{l}\text { Início da onda de mídia em } \\
\text { massa }\end{array}$ & $\begin{array}{l}\text { O ano de } 2012 \text { foi considerado pelo jornal norte-americano New } \\
\text { York Times como o ano dos MOOC, na edição de novembro de } \\
2012 \text {. } \\
\text { http://www.nytimes.com/2012/11/04/education/edlife/massive-open-online-courses- } \\
\text { are-multiplying-at-a-rapid-pace.html?pagewanted=all\& } r=0 \\
\text { A revista Time Magazine dedicou a capa da edição de outubro de } \\
2012 \text { a uma série de reportagens sobre a reinvenção da educação e } \\
\text { os MOOC figuravam como uma das principais vias de análise. } \\
\text { http://content.time.com/time/magazine/europe/0,9263,901121029,00.html }\end{array}$ \\
\hline $2012-2013$ & $\begin{array}{l}\text { Proliferação de } \\
\text { Fornecedores e atividade } \\
\text { acontece além dos } \\
\text { adotantes iniciais }\end{array}$ & $\begin{array}{l}\text { Fundação do Cousera, EdX, Udacity, MiriadaX e FutureLearn no } \\
\text { final do ano de 2012. Juntos em 2014, eles respondem por mais de } \\
15 \text { milhões de alunos cadastrados e representam mais de } 60 \% \text { da } \\
\text { oferta de cursos na modalidade MOOC. } \\
\text { https://www. edsurge.com/news/2014-12-26-moocs-in-2014-breaking-down-the- } \\
\text { numbers }\end{array}$ \\
\hline
\end{tabular}

Quadro 1 - Cronograma de Acontecimentos (Evidência de passagem pelos eventos previstos no Hype Cycle) - Período 2008 a 2013 


\begin{tabular}{|c|c|c|}
\hline Ano & Expectativa & Evidências \\
\hline 2013-2014 & $\begin{array}{lr}\text { Início de } \quad \text { Publicidade } \\
\text { Negativa, seguida } & \text { de } \\
\text { consolidação } & \text { de } \\
\text { fornecedores e falhas } & \end{array}$ & $\begin{array}{l}\text { O próprio Jornal New York Times que havia colocado os MOOC na } \\
\text { mais alta posição em 2012, volta a tratar do tema, mas agora com } \\
\text { uma conotação negativa, sob o título da reportagem } \\
\text { "Desmistificando os MOOC", que veio a público na edição de } \\
\text { outubro de } 2014 \text {. } \\
\text { http://www.nytimes.com/2014/11/02/education/edlife/demystifying-the-mooc.html } \\
\text { Na academia a discussão fica ainda mais acalorada, tendo como } \\
\text { epicentro a Universidade de São José na Califórnia, que faz um } \\
\text { experimento de substituição de algumas disciplinas do formato } \\
\text { presencial para o formato online através da plataforma MOOC EdX. } \\
\text { O resultado é um índice de reprovação muito maior do que a } \\
\text { contrapartida presencial. O experimento, considerado um erro, } \\
\text { desperta uma discussão entre acadêmicos sobre a eficácia dos } \\
\text { MOOC e sua real motivação. Esta discussão é bem resumida em } \\
\text { uma postagem de blog de George Siemens e nas cartas anexadas } \\
\text { dos professores do departamento de filosofia da Universidade de } \\
\text { São José (SJSU) e do professor Michael Sandel, da Universidade } \\
\text { de Harvard (consultar os anexos I e II). A promessa inicial dos } \\
\text { MOOC de "resolver os problemas da educação" parece ser falha. } \\
\text { https://allmoocs.wordpress.com/2013/12/23/2013-in-moocs-which-event-best- } \\
\text { defined-the-quest-to-solve-education/\#more-574 }\end{array}$ \\
\hline 2014-2016 & $\begin{array}{l}\text { Segunda e Terceira rodada } \\
\text { de financiamento de capital } \\
\text { de risco / Menos de } 5 \% \text { do } \\
\text { público potencial adotou a } \\
\text { tecnologia }\end{array}$ & $\begin{array}{l}\text { Coursera, Udacity, entre outros provedores de MOOC em todo } \\
\text { mundo recebem rodadas de capital de risco para acelerar } \\
\text { crescimento. } \\
\text { https://techcrunch.com/2015/11/11/udacity-raises-105-million-series-d-bringing- } \\
\text { valuation-to-1-billion/ } \\
\text { https://techcrunch.com/2015/08/25/coursera-raises-49-5m-series-c-funding-led-by- } \\
\text { nea-expects-second-closing-will-bring-total-to-60m/ }\end{array}$ \\
\hline $2016-\ldots$ & $\begin{array}{l}\text { Segunda geração de } \\
\text { produtos, alguns serviços }\end{array}$ & <fase em curso, evidências a serem coletadas no futuro próximo $>$ \\
\hline
\end{tabular}

Quadro 2 - Cronograma de Acontecimentos (Evidência de passagem pelos eventos previstos no Hype Cycle) - Período 2013 a 2017

De acordo com o "Hype Cycle", o processo de maturação dos MOOC estaria no final da terceira fase (indicado na próxima figura). Depois de passar pela primeira fase do Gatilho Tecnológico nos anos de 2008 a 2011, em seguida pela segunda fase do Pico de Expectativas Inflacionadas nos anos 2012 a 2013 e mais recentemente pela terceira fase do Vale das Desilusões de 2014 a 2017, o 
ciclo começa a dar sinais da chegada da próxima fase a partir do ano de 2018. Ainda é cedo para afirmar que a curva descendente atingiu seu ponto de inflexão. Estas análises só podem ser feitas com uma janela maior de tempo a partir do nascimento da tecnologia. Entretanto, a expectativa, segundo o "Hype Cycle" é que uma segunda geração de produtos comece a aparecer, consertando alguns erros da geração anterior e melhorando a experiência dos adotantes - tanto as instituições de ensino quanto alunos e professores.

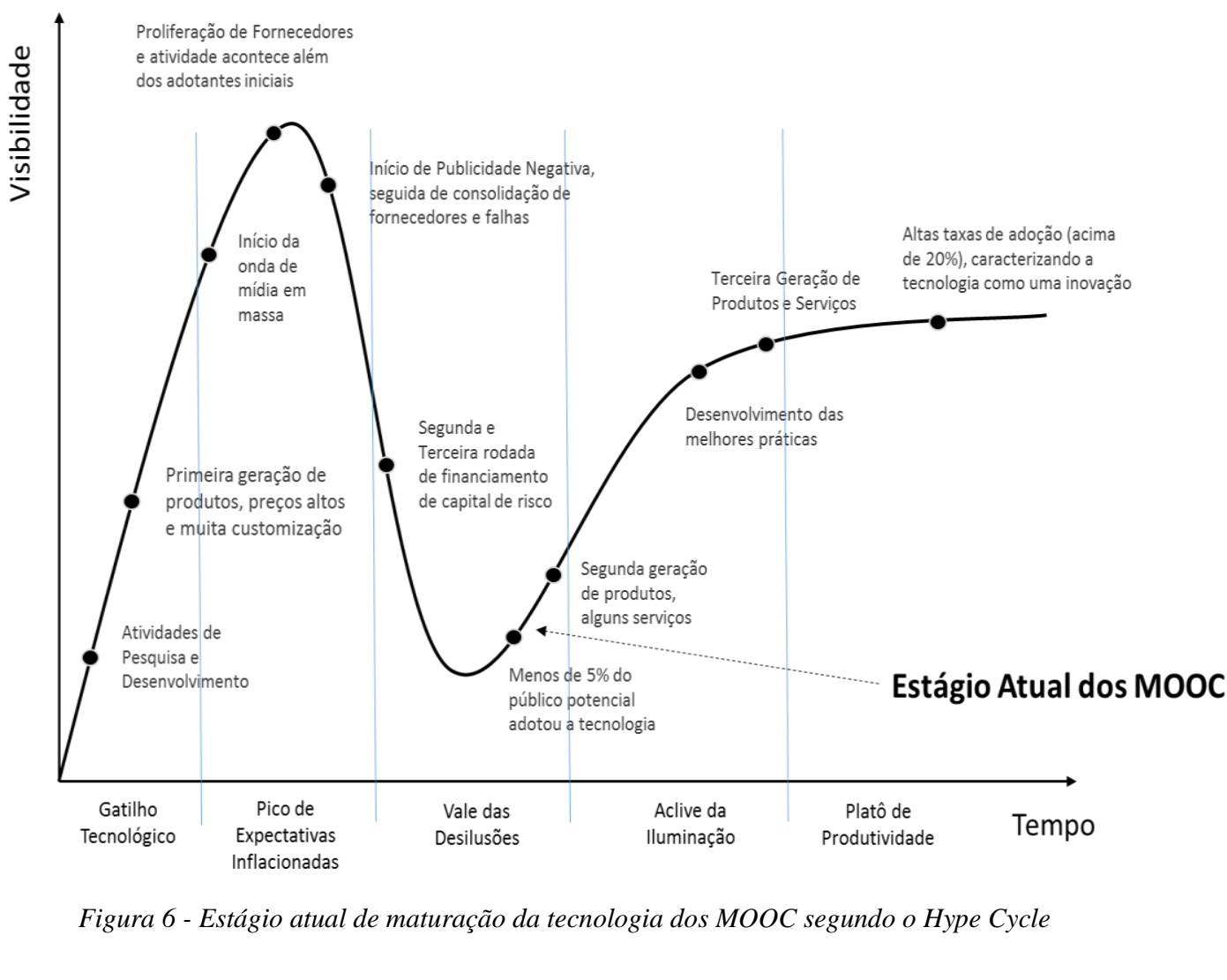

Passamos agora para a tarefa de cobrir o espectro de atuação dos MOOC, utilizando para isso um sistema de classificação que diferencie os formatos de MOOC atualmente disponíveis.

\section{2}

\section{Classificação taxonômica dos MOOC}

A tarefa de criar classificações de novas tecnologias, apesar de um processo muito útil para organizar a pesquisa e desenvolvimento, pode ser bastante complexa e controversa. O artigo "A typology and dimensions of a description framework for MOOCs" (ROSSELLE, M. et al, 2014), deixa isso bastante explícito ao tentar fazer um apanhado das classificações existentes até o 
ano de 2014 e ainda se propõe a criar seus próprios arranjos. No final, os próprios autores afirmam que "este estudo nos ensina que estas tipologias confundem as pessoas" (ROSSELLE, M. et al, 2014). Os tipos mencionados, literalmente dezenas deles, vão de nomes como xMOOC, cMOOC, tMOOC, transferMOOC, synchMOOC, iMOOC, alphaMOOC, bMOOC, groupMOOC, que criam variações a partir da adição de letras e prefixos ao acrônimo original MOOC, até versões que partem para classificações adicionando novos nomes como "Scene MOOC", "Cockpit MOOC", "Public Space MOOC", "Ecosystem MOOC”, dentre outros. Se ainda formos entrar nas dimensões criadas para gerar estas classes, a confusão fica ainda maior, alternando entre a falta de critério e a busca por referências um tanto remotas para ancorar os conceitos. Registrando rapidamente algumas delas, podemos citar as dimensões humana, contextual, instrucional, avaliativa, funcional, além de outros métodos específicos (ROSSELLE, M. et al, 2014). Ou seja, pouca parcimônia e ao mesmo tempo dificuldades de se criar alguma explicação dos modelos.

Entretanto, como já citado anteriormente, fazer uma classificação dos MOOC é algo importante para organizar a pesquisa e o desenvolvimento de novas ideias, especialmente neste trabalho que se propõe a adotar um caráter normativo quanto a critérios de avaliação da qualidade na comunicação em MOOC. Estariam estes critérios sendo prescritos para todo tipo de MOOC? Caberiam eles em qualquer produto de MOOC que se encontra atualmente disponível? A resposta só seria sim, caso houvesse pouca variância entre os formatos de MOOC existentes e, desta forma, não seria tão perigoso trabalhar sem uma classificação. Mas este não é o caso, ao menos no cenário de ofertas de MOOC que vemos atualmente à disposição de alunos de todo mundo. Existe uma variação estrutural, no nível pedagógico, que diferencia drasticamente os produtos de MOOC.

Seguiremos então dois formatos de classificação neste trabalho. A primeira, uma classificação tipológica, que serve para gerar uma diferenciação básica das estruturas pedagógicas utilizadas nos MOOC. A segundo, uma classificação taxonômica, que serve para gerar um conjunto de meta-dados (metadata) úteis no processo de informação, filtragem e seleção de MOOC. A taxonomia, conforme aqui trabalhamos, é um conjunto mais abrangente e inclui dentro dele o conjunto tipológico. Entretanto, a tipologia é o elemento mais importante, ao menos para este trabalho, por ser o traço de diferenciação entre os produtos de MOOC. Para 
explorar estes dois formatos de classificação, vamos nos basear em dois trabalhos, ambos publicados no ano de 2013. O primeiro, com o título "MOOCs: A Learning Journey", aborda os aspectos da tipologia (Smith e Eng, 2013). O segundo, com o título "Welcome to the moocspace: a proposed theory and taxonomy for Massive open online courses", aborda aspectos da taxonomia (Schneider, 2013).

\subsection{1 \\ Tipologia}

Segundo Smith e Eng (2013), com a proliferação dos MOOC, houve uma clara separação de dois modelos pedagógicos distintos. A primeira categoria, baseada na Teoria do Conectivismo, é chamada de cMOOC. A segunda categoria, baseada na Teoria Cognitivista-Comportamental, é chamada de xMOOC. O quadro a seguir lista as principais características de cada uma das duas categorias, baseadas em quatro critérios de análise.

\begin{tabular}{|c|c|c|}
\hline Critério & cMOOC & xMOOC \\
\hline Conteúdo do Curso & $\begin{array}{l}\text { - Conteúdo não definido e não controlado } \\
\text { - Natureza exploratória } \\
\text { - Conteúdo inicial postado como um ponto de } \\
\text { partida } \\
\text { - Alunos são encorajados a compartilhar, } \\
\text { contribuir e ampliar o material do curso }\end{array}$ & $\begin{array}{l}\text { - Conteúdo específico, definido, } \\
\text { empacotado e de certa forma } \\
\text { controlado } \\
\text { - Abordagem similar a sala de } \\
\text { aula tradicional } \\
\text { - Todo material do curso postado } \\
\text { online }\end{array}$ \\
\hline Interação & $\begin{array}{l}\text { - Predominantemente entre pares e } \\
\text { monitorada pelos instrutores do curso } \\
\text { - Encorajada a participar em fóruns } \\
\text { descentralizados e plataformas de mídias } \\
\text { sociais }\end{array}$ & $\begin{array}{l}\text { - Feedback do instrutor e dos } \\
\text { pares } \\
\text { - Fóruns de discussão na sua } \\
\text { maioria centralizados na página } \\
\text { do curso }\end{array}$ \\
\hline Métodos de Avaliação & $\begin{array}{l}\text { - Formativo } \\
\text { - Somativa } \\
\text { - Instrutor dá a nota } \\
\text { - Avaliação entre pares }\end{array}$ & $\begin{array}{l}\text { - Formativo } \\
\text { - Somativa } \\
\text { - Automatizado } \\
\text { - Avaliação entre pares }\end{array}$ \\
\hline Papel do Instrutor/Aluno & $\begin{array}{l}\text { - Não tradicional: "distribuído, caótico, } \\
\text { emergente" } \\
\text { - Espera-se que os alunos cresçam, } \\
\text { expandam seus domínios e compartilhem } \\
\text { sentido através da criação de artefatos } \\
\text { - Aprendizagem autônoma }\end{array}$ & $\begin{array}{l}\text { - Tradicional: lógica de } \\
\text { transferência e aquisição do } \\
\text { conhecimento pelos alunos }\end{array}$ \\
\hline Pedagogia & Conectivista & Cognitivo-Comportamental \\
\hline
\end{tabular}

Quadro 3 - Comparação das características dos cMOOC e xMOOC (Smith e Eng, 2013) 
Como se pode perceber na tabela, existe uma diferença entre as características das duas modalidades de MOOC, segundo os critérios estabelecidos por Smith e Eng (2013). Entretanto estes critérios não são objetivos o suficiente para se fazer uma distinção inquestionável sobre a classificação tipológica de um MOOC. Mas se pensarmos com uma lógica de uma escala contínua de medida classificatória onde os tipos estão em dois polos opostos, podemos medir de alguma forma a aproximação dos polos. Esta escala é apresentada por Yousef et al (2014):

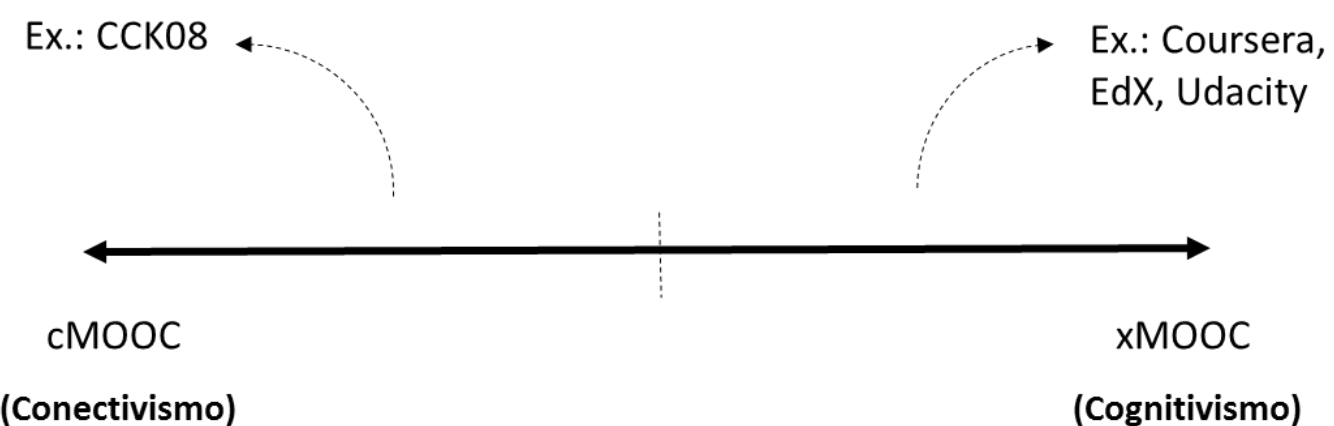

Figura 7 - Escala classificatória dos MOOC segundo Yousef (2014)

Abaixo tecemos alguns comentários sobre a tabela tipológica de Smith e Eng:

- O critério de "Conteúdo do Curso" parece fornecer os traços mais marcantes de distinção entre os dois tipos - os xMOOC tem um currículo definido e válido para toda a turma, enquanto os cMOOC não. Pelo fato de ter um currículo, um xMOOC pode trabalhar no desenvolvimento prévio de um conteúdo didático - seja ele próprio ou selecionado de fontes externas. No caso dos cMOOC o conteúdo tem uma natureza mais exploratória e dinâmica, ou seja, os participantes exploram o campo na busca ou desenvolvimento de conteúdo para o curso. Este aspecto da natureza do conteúdo é um exemplo de uma característica não muito clara e objetiva. Até que ponto um xMOOC também não estimula a exploração de novas fontes? E até que ponto um cMOOC também não trabalha com conteúdo previamente definido, como foi bem citado na tabela, um conteúdo que sirva "como ponto de partida". Desta forma, o traço marcante de identificação da tipologia no que tange o critério de conteúdo 
é a existência ou não de um currículo (ou programa de curso) previamente definido e a sua abrangência com relação aos alunos do curso.

- Os critérios de "interação" e "papel do instrutor/aluno", no nosso entendimento, apresentam certa sobreposição. O elemento essencial que está subjacente aos dois critérios é o formato de comunicação. Nos parece razoável aglutinar ambos os critérios dentro de um único critério mais amplo. Yousef et al (2014), que também faz uma análise das tipologias, utilizou o termo "Comunicação" para descrever estes critérios. Entretanto, ele coloca o provedor do sistema de comunicação como característica chave de diferenciação entre as tipologias - dentro ou fora da plataforma MOOC. Esta característica não parece ser muito explicativa, se considerarmos, por exemplo, que ambos os tipos de MOOC utilizam o Google Hangout como plataforma de comunicação em vídeo conferências. Além disso, Siemens desenvolveu uma plataforma ${ }^{17}$ de cMOOC que integrava ferramentas de comunicação baseadas em murais de notícias, mensagens instantâneas curtas e organização de tópicos por palavraschave. Isso é mais uma evidência que a inserção ou não da ferramenta de comunicação na plataforma MOOC não seria um fator de determinação da tipologia. Entretanto, existe sim uma forma de se distinguir os padrões de comunicação nos dois diferentes formatos de MOOC. Para isso, é necessário analisar todo tipo de comunicação que ocorre na esfera do MOOC e não somente nas chamadas "ferramentas" de comunicação. Isso significa que o conteúdo didático do curso também é comunicativo. Lições em texto, vídeo, áudio ou qualquer outra mídia também devem ser inseridas na análise de comunicação e não somente as mensagens produzidas em fóruns, chats e outros formatos de troca de mensagens instantâneas ou não. Este é o paradigma que deve ser quebrado. Como é tratado, na esfera do curso, por exemplo, um vídeo de cinco minutos com o professor explicando um determinado tópico? Ele faz parte de um diálogo mais amplo e serviu para fomentar a comunicação entre os

\footnotetext{
${ }^{17}$ Em 2013, Siemens reuniu uma equipe com a missão de construir uma plataforma de MOOC baseada nas ideias do conectivismo, ou seja, um cMOOC. Esta plataforma foi lançada em versão beta no ano de 2014 e nomeada Prosolo. Uma das suas principais funcionalidades era associada a ideia de gestão de competências. Aparentemente o projeto da plataforma não seguiu adiante baseado em busca na internet em 29/03/2016. Alguns registros do projeto Prosolo podem ser encontrados no link de um blog http://blog.prosolo.ca/
} 
participantes do curso? Isso inclui os professores, tutores, instrutores e qualquer outro personagem participativo, além dos alunos. Atualmente, conteúdo e comunicação não se misturam na análise. Propomos que, para a classificação das tipologias de MOOC, passe a valer o entendimento que o currículo é traço de distinção do critério de conteúdo, e o tipo de comunicação gerada a partir do conteúdo é o traço de distinção do tipo de interação que acontece no ambiente do MOOC.

- O critério de "Métodos de Avaliação", segundo a análise de características feitas por Smith e Eng (2013), apresenta várias sobreposições e aponta como traço de diferenciação o método de geração de notas pelo lado do provedor do MOOC. Segundo a análise das autoras, os cMOOC teriam notas geradas pela equipe de docência (professores, instrutores, tutores, etc.), enquanto os XMOOC teriam um sistema automatizado de geração de notas (baseada na correção automática de exames como o de múltipla escolha, por exemplo). As outras características (avaliação Formativa, Somativa e por pares) aparece presente em ambos os tipos e, portanto, não tem capacidade explicativa da tipologia. Qualquer MOOC que apresente, por exemplo, um sistema de avaliação entre pares, poderia ser classificado tanto como xMOOC quanto cMOOC. Apresentamos aqui um argumento favorável ao uso dos métodos de avaliação como um critério de definição tipológico. Entretanto, propomos uma definição mais clara que possa distinguir os modelos.

- Considerando a distinção curricular que existe entre as modalidades de MOOC (generalizada versus individualizada), propomos uma abordagem predominantemente formativa para os cMOOC. Seguindo a classificação de Bloom para formas de avaliação (Bloom et. al, 1971), a avaliação formativa é aquela realizada durante todo o curso, com o objetivo de verificar se os alunos estão conquistando a proficiência nos objetivos de aprendizagem para cada etapa. Esta avaliação provê feedback instantâneo para o direcionamento do aluno nos seus próximos passos no processo de ensino. Ela difere da avaliação Somativa, que tem como objetivo a classificação dos alunos de acordo com níveis de aproveitamento previamente estabelecidos, normalmente para certificação ou passagem para o próximo nível. 
- Propomos ainda a criação de um quarto critério, não tratado na tipologia de Smith e Eng, que explora a questão temporal do curso. Tipicamente, os xMOOC replicam uma lógica de aula baseada em cursos baseados em um programa com carga horária definida. Em um modelo mais adaptativo, como é o caso do cMOOC, a restrição temporal perde o sentido - tanto para mais quanto para menos carga horária em relação ao programa padrão. Ou seja, alguns alunos vão atingir a proficiência de forma mais rápida e outros menos. Sendo assim, propomos uma distinção no critério duração, onde o xMOOC tem uma duração padronizada para toda a turma enquanto o cMOOC tem uma duração diversificada dependendo do avanço de cada aluno dentro dos objetivos de aprendizagem.

A partir da classificação tipológica de Smith e Eng (2013), a revisão de tipologias feita por Youssef et al (2014) e os comentários acima descritos, propomos uma nova visualização das tipologias de MOOC, a ser representada no quadro a seguir:

\begin{tabular}{|c|c|c|}
\hline Critério & xMOOC & cMOOC \\
\hline Conteúdo & $\begin{array}{c}\text { Currículo Estático e } \\
\text { Generalizado }\end{array}$ & $\begin{array}{c}\text { Currículo Dinâmico e } \\
\text { Individualizado }\end{array}$ \\
\hline Interação & $\begin{array}{c}\text { Predominantemente } \\
\text { Monológica }\end{array}$ & $\begin{array}{c}\text { Predominantemente } \\
\text { Dialógica }\end{array}$ \\
\hline Avaliação & $\begin{array}{c}\text { Predominantemente } \\
\text { Somativa }\end{array}$ & $\begin{array}{c}\text { Predominantemente } \\
\text { Formativa }\end{array}$ \\
\hline Duração & Padronizada & Diversificada \\
\hline Pedagogia & Cognitivo-Comportamental & Conectivista \\
\hline
\end{tabular}

Quadro 4 - Comparação adaptada das características dos cMOOC e XMOOC. Desenvolvimento próprio dos autores. 


\subsection{2 Taxonomia}

No tópico anterior propusemos o uso da tipologia de Smith e Eng (2013) para classificação dos MOOC em xMOOC ou cMOOC. Entretanto, realizamos algumas adaptações nos critérios utilizados pelas autoras, de forma a refletir uma distinção mais clara e efetiva entre os dois tipos de MOOC. A partir desta classificação tipológica, seguimos agora para uma classificação taxonômica, que inclui a tipologia e outras informações objetivas do curso que estiver sofrendo a análise. Estas informações somadas, formam o conjunto de meta-dados, que pode ser útil em processos de filtragem e seleção de cursos MOOC. Segundo Schneider (2013), a criação de um sistema taxonômico para os MOOC tem o objetivo de desenvolver uma linguagem compartilhada para pesquisadores e aqueles que projetam MOOC. Fazemos aqui uma extensão da utilidade da taxonomia também para aqueles que distribuem os cursos e para aqueles que vão participar dos MOOC (sejam eles docentes ou discentes). A taxonomia engloba características gerais dos cursos, da sua estrutura e do perfil da audiência. Ela se torna instrumental para viabilizar a comparação entre os produtos de MOOC, que podem ter uma variação enorme entre eles.

Schneider (2013) propõe dois grandes blocos para se definir a taxonomia. O primeiro deles, que a autora chama de "Estrutura Geral", lista uma série de categorias e subcategorias objetivas para classificação dos MOOC, entre elas o nome, o autor, a plataforma, entre outros. A fim de criar esta lista, utiliza uma terminologia criada anteriormente em uma pesquisa e registrada sob o nome de LRMI (Grover, Franz, Schneider e Pea, 2013), cujo acrônimo significa Learning Resource Metadata Initiative e pode ser traduzido como "Iniciativa de MetaDados para Recursos de Aprendizagem". Schneider adiciona algumas outras classes que julgou complementares aos Meta-Dados originais propostos pela LRMI. A lista completa é apresentada no quadro a seguir. 


\begin{tabular}{|c|c|}
\hline Categoria & Descrição \\
\hline Nome (LRMI) & $<$ Nome do curso $>$ \\
\hline $\begin{array}{l}\text { Identificação Numérica (geração } \\
\text { automática pelo sistema) }\end{array}$ & <Código de identificação do curso proposto pela instituição de ensino> \\
\hline Autor (LRMI) & $<$ Nome do autor $>$ \\
\hline Instituição (LRMI) & $<$ Nome da instituição afiliada ao curso $>$ \\
\hline Plataforma & <Nome da Plataforma de distribuição do curso> \\
\hline Idioma (LRMI) & $\begin{array}{l}\text { <|dioma primário do curso, que tipicamente é utilizado tanto na } \\
\text { descrição quanto nas instruções iniciais do curso> }\end{array}$ \\
\hline Domínio & $\begin{array}{l}\text { <Palavras-Chave que identifiquem domínios cobertos pelo curso, } \\
\text { exemplos: matemática, ciências, computação, humanas, ciências } \\
\text { sociais, profissional, pessoal, etc.> }\end{array}$ \\
\hline Nível & $\begin{array}{l}\text { <Nível da escolaridade proposta pelo curso, variando entre ensino } \\
\text { fundamental, ensino médio, ensino técnico, ensino superior, extensão, } \\
\text { educação continuada, ensino livre> }\end{array}$ \\
\hline Público-Alvo & $\begin{array}{l}\text { <Estudantes, profissionais de uma determinada área, educação } \\
\text { continuada, etc.> }\end{array}$ \\
\hline Uso & <Educacional, evento, público, etc.> \\
\hline Passo & $\begin{array}{l}\text { <Baseado em turmas versus individual, carga de trabalho esperada, } \\
\text { etc.> }\end{array}$ \\
\hline Acreditação & <Disponibilidade de certificados, transferência de créditos> \\
\hline
\end{tabular}

Quadro 5 - Lista completa de meta dados (SCHNEIDER, 2013)

O segundo bloco é identificado como "Elementos do Ambiente Interativo de Aprendizagem" ou ILE (Interactive Learning Environments), lista categorias associadas a questões pedagógicas do curso, não tão objetivas, como por exemplo a modalidade de instrução e o formato do conteúdo. A lista completa é apresentada no quadro a seguir. 


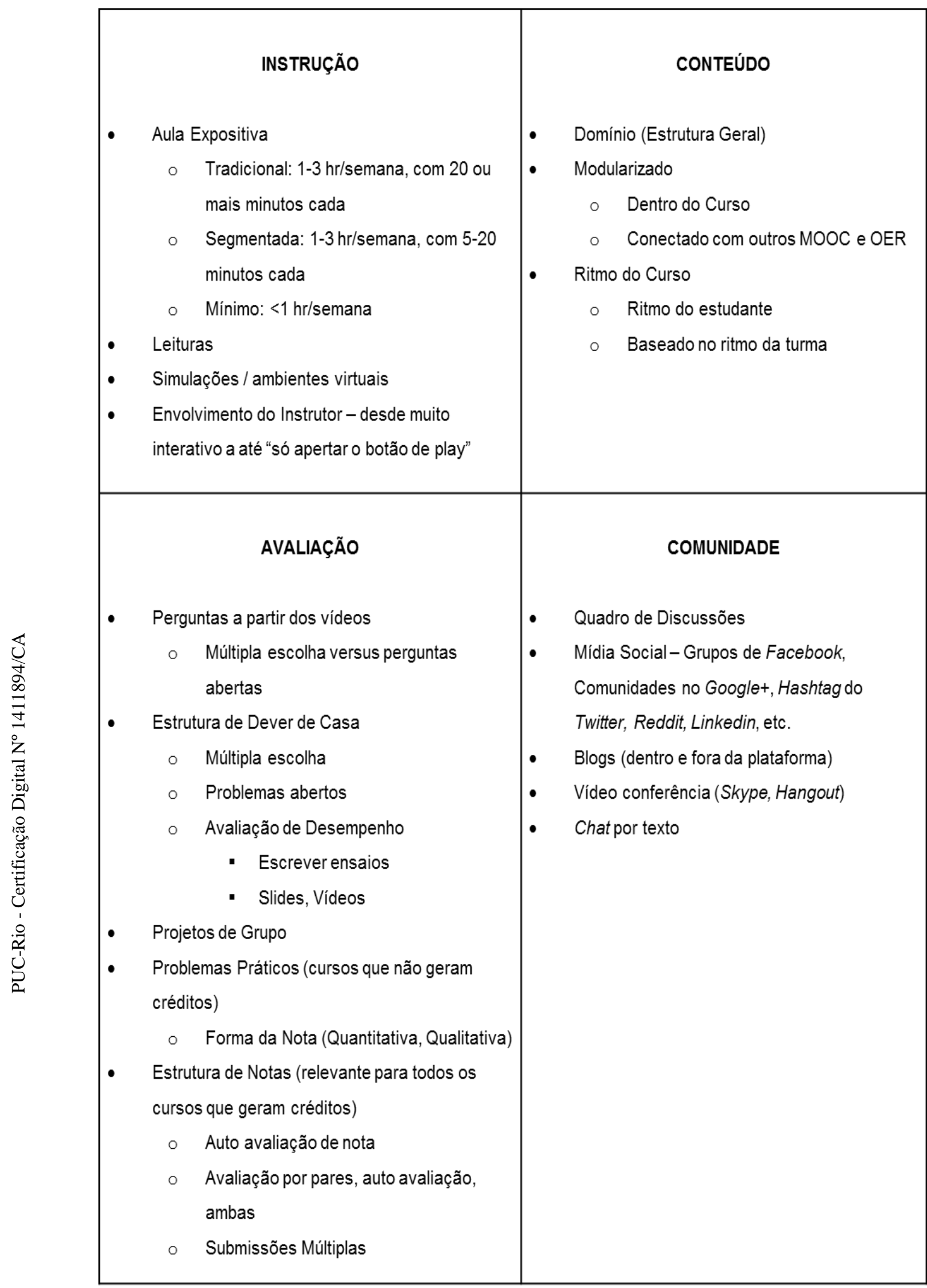

Quadro 6 - Lista de Elementos do Ambiente Interativo de Aprendizagem (SCHNEIDER, 2013) 
Schneider fez um trabalho de consolidação bastante interessante, mas que julgamos ainda um tanto complexo de preenchimento. São muitas categorias e subcategorias, incluindo algumas delas não tanto objetivas. Propomos a seguir uma Taxonomia mais enxuta e que ao mesmo tempo incorpora a Tipologia, que inicialmente poderia ser interpretada como "concorrente" a taxonomia.

Uma primeira alteração que propomos é relativa ao nome dos dois blocos. O primeiro bloco passa a se chamar "Meta-dados", que é um conceito mais conhecido e uniforme em diversas áreas de conhecimento, tanto acadêmico quanto leigo. Dentro desta categoria, mantivemos todas as classes cuja avaliação mostrase bastante objetiva, ou seja, não há muita margem para respostas ambíguas. Todas as categorias não objetivas, que geralmente coincidem com aquelas associadas a prática pedagógica do curso, devem ser respondidas pelo segundo bloco.

Uma segunda alteração foi em relação a identificação numérica do curso, que Schneider propõe como um código gerado automaticamente pelo sistema de taxonomia. Entretanto, este campo não tem nenhuma utilidade na distinção dos MOOC, sendo somente um mero campo identificador chave na base de dados. Acreditamos, que este campo não precisaria ser listado como uma categoria, pois só faria sentido se houvesse uma plataforma única de classificação taxonômica, o que não parece ser o caso. Portanto, convertemos o campo de identificação numérica para registrar o código utilizado pela instituição provedora para identificar o curso. Este código pode ser útil na busca e seleção de um curso. Por exemplo, o código CCK08 ficou conhecido e muitas pessoas buscam o curso diretamente por este código e não pelo nome.

Uma terceira alteração que propomos é no campo Domínio proposto por Schneider. Este campo, apesar de muito importante, é um dos campos mais complexos de padronizar. Dentro dele seria possível inserir toda a lista de domínios científicos e leigos de conhecimento. Cabem nomes como matemática, desenho, humanidades, medicina, justiça, inteligência artificial, barbearia, gastronomia, dentre milhares de outros nomes. Esse campo expressa toda a variedade de temas explorados nos MOOC. Schneider propõe uma abordagem por quatro classes pré-definidas (Computação/STEM ${ }^{18}$, Humanísticas, Profissional e Pessoal) aglutinadas com subclasses a serem elegidas de forma livre (ex.:

\footnotetext{
${ }^{18}$ STEM, acrônimo em inglês para os termos Ciências, Tecnologia, Engenharia e Matemática
} 
profissional-negócios). Este formato utilizado não parece permitir a inclusão de toda a diversidade dos MOOC. Além disso parece restritivo com relação a cursos que tratem de mais de um tópico. Nossa abordagem, neste ponto, propõe um sistema de palavras-chave, similar ao que se usa para organizar conteúdo em serviços massivos como o Youtube, Blogs, etc. A abordagem por palavras-chave não é perfeito e pode gerar confusão considerando que a pessoa que estiver fazendo a classificação utilizará termos compatíveis com suas experiências prévias e seu próprio nível de conhecimento específico na área. Por outro lado, não há como pensar taxonomia para conteúdo sem informações para domínio. Talvez haja uma solução mais interessante do que essa de palavras-chave que estamos aqui propondo.

Uma quarta alteração que propomos é em relação ao campo acreditação. Schneider propõe que este campo deveria registrar a disponibilidade de certificado e a questão de transferência de créditos. Propomos aqui quebrar este campo em três campos distintos, sendo o primeiro dedicado a registrar o modelo de acreditação, o segundo de certificação e o terceiro a transferência de créditos. Certificação e Acreditação não tem o mesmo significado, especialmente no contexto de educação. Qualquer curso pode emitir um certificado, no mínimo, de participação. Alguns podem emitir certificados que valem como diploma e tem maior reconhecimento público. Porém, a acreditação é um elemento externo a instituição - algo que ela pode conquistar, mas não pode repassar, pois se fosse este o caso ela não seria uma instituição de ensino, mas sim uma instituição acreditadora.

A partir da proposta de Taxonomia de Schneider e das propostas de alteração descritas acima, chegamos ao seguinte quadro de Meta-dados, registrado no quadro a seguir. 


\begin{tabular}{|c|c|}
\hline Categoria & Descrição \\
\hline Nome & $<$ Nome do curso $>$ \\
\hline Identificação Numérica & <Código de identificação do curso proposto pela instituição de ensino> \\
\hline Autor & $<$ Nome do autor $>$ \\
\hline Instituição & $<$ Nome da instituição afiliada ao curso $>$ \\
\hline Plataforma & <Nome da Plataforma de distribuição do curso> \\
\hline Idioma Primário & $\begin{array}{l}\text { <|dioma primário do curso, que tipicamente é utilizado tanto na descrição } \\
\text { quanto nas instruções iniciais do curso> }\end{array}$ \\
\hline Domínio & $<$ Palavras-Chave que identifiquem domínios cobertos pelo curso $>$ \\
\hline Nível & $\begin{array}{l}\text { <Nível da escolaridade proposta pelo curso, variando entre ensino } \\
\text { fundamental, ensino médio, ensino técnico, ensino superior, extensão, } \\
\text { educação continuada, ensinolivre> }\end{array}$ \\
\hline Acreditação & <Sistemas de acreditação do curso> \\
\hline Certificação Institucional & $<$ Sim/Não $>$ \\
\hline Transferência de Créditos & $\begin{array}{l}\text { <Listagem das instituições ou sistemas que reconhecem como válidos os } \\
\text { créditos do curso> }\end{array}$ \\
\hline
\end{tabular}

Quadro 7 - Proposta de Campos para Meta-Dados. Autoria própria.

É interessante perceber que nenhuma das categorias excluídas ou que sofreram alteração, fazia parte do grupo previamente listado no LRMI. Na nossa concepção, Schneider tentou ampliar o trabalho do LRMI para incluir mais categorias específicas dos MOOC, entretanto, ela não manteve o viés da objetividade na seleção destes critérios - algo que parece ter sido bastante considerado na criação do LRMI. O que fizemos até então foi de certa forma restringir o trabalho de Schneider a critérios objetivos, que produzam taxonomias mais claras e uniformes para os MOOC.

Seguimos agora para o segundo bloco, que Schneider definiu como Interactive Learning Environment (ILE). Conforme mencionamos anteriormente no texto, decidimos chamar este bloco de Tipologia. Isso foi feito porque ao analisar as dimensões propostas por Schneider para este bloco, percebemos que elas praticamente coincidem com as categorias estabelecidas anteriormente por 
Smith e Eng (2013). Estas últimas, optamos por consolidar em somente duas categorias (xMOOC e cMOOC) onde cada uma delas incorpora elementos pedagógicos que as diferenciam. Portanto, isso que está sendo chamado de segundo bloco, é na realidade uma categoria de análise, que vamos chamar simplesmente de Tipologia. Ou seja, a taxonomia dos MOOC é composta por uma série de Meta-Dados e uma classificação de Tipologia.

A seguir apresentamos dois quadros. O primeiro deles resume nossa proposta para os campos de classificação taxonômica de cursos MOOC e o segundo quadro mostra dois exemplos de classificação taxonômica baseados nesta proposta, a partir de produtos de MOOC existentes atualmente.

\begin{tabular}{|c|c|}
\hline Categoria & Descrição \\
\hline Nome & $<$ Nome do curso $>$ \\
\hline Identificação Numérica & <Código de identificação do curso proposto pela instituição de ensino> \\
\hline Autor & $<$ Nome do autor $>$ \\
\hline Instituição & <Nome da instituição afiliada ao curso> \\
\hline Plataforma & <Nome da Plataforma de distribuição do curso> \\
\hline Idioma Primário & $\begin{array}{l}\text { <ldioma primário do curso, que tipicamente é utilizado tanto na descrição } \\
\text { quanto nas instruções iniciais do curso> }\end{array}$ \\
\hline Domínio & $<$ Palavras-Chave que identifiquem domínios cobertos pelo curso $>$ \\
\hline Nível & $\begin{array}{l}\text { <Nível da escolaridade proposta pelo curso, variando entre ensino } \\
\text { fundamental, ensino médio, ensino técnico, ensino superior, extensão, } \\
\text { educação continuada, ensino livre> }\end{array}$ \\
\hline Acreditação & $<$ Sistemas de acreditação do curso $>$ \\
\hline Certificação Institucional & $\langle$ Sim/Não $>$ \\
\hline Transferência de Créditos & $\begin{array}{l}\text { <Listagem das instituições ou sistemas que reconhecem como válidos os } \\
\text { créditos do curso> }\end{array}$ \\
\hline Tipologia & $<\mathrm{XMOOC}$ ou cMOOC $>$ \\
\hline
\end{tabular}

Quadro 8 - Proposta de Campos para Classificação Taxonômica de MOOC. Autoria própria. 


\begin{tabular}{|c|c|c|}
\hline Nome & $\begin{array}{c}\text { Connectivism and Connective } \\
\text { Knowledge }\end{array}$ & $\begin{array}{l}\text { Introduction to Artificial } \\
\text { Intelligence }\end{array}$ \\
\hline Identificação Numérica & CCK08 & CS221 \\
\hline Autor & $\begin{array}{l}\text { George Siemens } \\
\text { Richard Downes }\end{array}$ & $\begin{array}{l}\text { Sebastian Thrun } \\
\text { Peter Norvig }\end{array}$ \\
\hline Instituição & Universidade de Manitoba & Universidade de Stanford \\
\hline Plataforma & Moodle & Udacity \\
\hline Idioma Primário & Inglês & Inglês \\
\hline Domínio & $\begin{array}{c}\text { Educação, Conectivismo, } \\
\text { Pedagogia, Aprendizagem } \\
\text { em Rede, Cognição } \\
\text { Distribuída }\end{array}$ & $\begin{array}{l}\text { Ciência da Computação, } \\
\text { Inteligência Artificial, }\end{array}$ \\
\hline Nível & Ensino Superior & Ensino Superior \\
\hline Acreditação & - & - \\
\hline Certificação Institucional & Não & Sim \\
\hline Transferência de Créditos & Não & Não \\
\hline Tipologia & cMOOC & xMOOC \\
\hline
\end{tabular}

Quadro 9 - Exemplos de classificação taxonômica baseados em produtos de MOOC existentes

Este sistema de taxonomia acima criado, será utilizado neste trabalho como forma de classificar os produtos de MOOC. A partir deste sistema de classificação esperamos poder comparar diversos cursos de MOOC existentes, sem cair no problema de comparar formatos diferenciados, por exemplo, um curso MOOC de matemática elementar, voltado para o ensino fundamental, oferecido pela Khan Academy, tipo xMOOC, com um outro curso, por exemplo, de Métricas de Aprendizagem, voltado para o ensino superior, oferecido pela Universidade do Texas, tipo cMOOC. Apesar de ambos serem exemplos de MOOC, não podem ser comparados em todos os aspectos. 


\section{3 Análise crítica dos resultados}

Ainda é bastante cedo para julgar de forma extensiva os resultados atingidos pelos MOOC até o momento, pois ainda estamos em um momento de experimentação. Formas diferentes de produtos de MOOC tem nascido a cada dia, enriquecendo o espaço de discussão, abrindo oportunidade para mais pesquisa e novas propostas pedagógicas.

Entretanto, a experiência acumulada até o momento já permite uma análise de alguns resultados baseados nos casos das diversas plataformas MOOC que surgiram nesta primeira década de existência. Como trata-se de um ambiente digital mediado por tecnologia, a quantidade de conjuntos de dados gerados e acumulados a partir de ambientes de aprendizagem para MOOC é enorme. Entretanto, a maior parte das plataformas é privada e os dados não são, em sua maioria, abertos. Desta forma, existe uma dependência dos provedores a fim de que abram estes dados para instituições afiliadas realizarem pesquisas e publicarem os resultados. Esse é o caso, por exemplo, da plataforma EdX, afiliada às Universidades de Harvard e ao MIT. Posteriormente outras universidades entraram no consórcio. Já plataformas privadas como o Coursera e Udacity, que apesar de terem sido fundadas por professores e manterem relação direta com diversas instituições de ensino, liberam uma parcela pequena de dados de forma aberta para pesquisa.

A seguir, referenciamos ao trabalho de Bates (2016), que explora algumas das questões pedagógicas dos MOOC. Para contextualizar estas práticas, é importante comentar inicialmente o público que vem sendo atraído para os MOOC. Inicialmente se pensou que os MOOC seriam uma forma de educação livre e aberta que teria uma adesão enorme em regiões com poucas oportunidades de ensino e com baixo acesso à educação formal. Este cenário, de certa forma esperado pela simples definição do que seria um MOOC, ainda não aconteceu na prática. O aluno típico de MOOC até então, está longe de ser um sujeito sem escolaridade, morador de áreas rurais de países pobres, sem oportunidade escolar. Em uma pesquisa de Ho et al. (2014), pesquisadores da Universidade de Harvard e MIT descobriram que nos primeiros dezessete cursos oferecidos na plataforma EdX, 66\% dos participantes tinham ensino superior (diploma de bacharelado e/ou 
especialização, mestrado ou doutorado). Se analisado somente o perfil dos alunos que concluíram o curso, este percentual subia para $74 \%$. Essa informação parece não coincidir com a proposta inicial dos MOOC de democratizar a educação. Os pesquisadores Hollands e Tirthali, da Universidade de Columbia, em um estudo com oitenta entrevistados oriundos de sessenta e duas instituições provedoras de cursos em plataformas MOOC, argumentam que, apesar das plataformas MOOC estarem de fato provendo oportunidades de educação para milhões de alunos em todo mundo, a maior parte deles já são sujeitos bem-educados e empregados (HOLLANDS E TIRTHALI, 2014). Segundo os autores, até o presente momento, os MOOC podem estar contribuindo mais para o aumento das diferenças no acesso à educação do que o inverso - que era inicialmente esperado e continua sendo. Até o momento, na prática, os MOOC seguem o padrão de outros programas universitários de educação continuada, que tipicamente atraem um público com maior nível educacional e inseridos economicamente na sociedade (BATES, 2016).

Outro aspecto importante do perfil de aluno dos MOOC é a questão do comprometimento com o curso, que pode refletir diferentes graus de atenção e dedicação ao conteúdo ou somente a persistência em concluir o curso - como muito se vê na experiência presencial de educação, não mediada por tecnologia. Como se viu anteriormente na análise de ciclo de vida da tecnologia, foi citado o exemplo do curso da Udacity junto com a Universidade de São José, na Califórnia. Mesmo valendo créditos-aula, o grau de comprometimento com o curso foi muito inferior à sua contraparte que era oferecida em sala de aula. $\mathrm{O}$ nível de fracasso tanto em conclusão quanto aproveitamento do curso foi muito acima do mesmo curso tradicionalmente oferecido com um formato de instrução presencial, em turmas síncronas, em um ambiente físico compartilhado. Esta constatação não foi exclusiva da experiência com a Udacity - praticamente todas as plataformas apresentaram resultados semelhantes, dando início a um debate sobre a eficácia dos MOOC como uma prática pedagógica (BATES, 2016).

Saindo da discussão sobre a eficácia ou não dos MOOC e evidenciando fatos, pode-se observar um padrão no tipo de engajamento com os MOOC. Na mesma pesquisa citada anteriormente, Ho identificou quatro níveis de comprometimento a partir da observação de dezessete cursos oferecidos na plataforma EdX (HO ET AL, 2014). São eles: 
- Somente registro (35\%) - alunos que se registraram, mas nunca acessaram o material do curso;

- Observadores (56\%) - alunos não certificados que acessaram menos da metade dos materiais disponíveis do curso;

- Somente exploratório (4\%) - alunos não certificados que acessaram mais da metade dos materiais disponíveis do curso;

- Certificados (5\%) - alunos que obtiveram o certificado do curso.

Engle encontrou padrões similares nos MOOC da Universidade de British Columbia, na plataforma Coursera. De forma resumida, somente 5-10\% completam as atividades do curso e receberam a certificação (ENGLE, 2014). De qualquer forma, cabe notar que mesmo sendo uma proporção pequena que recebe o certificado, este número, se observado de forma absoluta, ainda é muito grande. Juntando os dados da pesquisa citada no EdX (17 cursos) com a de British Columbia (4 cursos), o total de alunos que completaram os cursos e receberam certificado foi de 51.000 pessoas. Ou seja, uma média de aproximadamente 2.500 certificados por curso (ENGLE, 2014).

Um aspecto interessante é que os estudos mencionados acima, baseados nas plataformas EdX e Coursera, são constituídos tipicamente de cursos no formato xMOOC. Poderíamos questionar se o mesmo estaria acontecendo com o formato cMOOC que, a priori, requer mais engajamento dos alunos para seu funcionamento. Entretanto, segundo a análise de Milligan existe um padrão similar de comprometimento nos cMOOC. Apesar de ter trabalhado com uma amostra pequena de vinte e nove pessoas participantes de um cMOOC, Miligan encontrou um padrão parecido de comprometimento (MILLIGAN, 2013):

- Participantes passivos - aqueles que se sentiam perdidos e raramente acessaram o curso;

- Observadores Passivos - aqueles que estavam seguindo o curso, mas não se engajaram em nenhuma das atividades;

- Participantes ativos - aqueles que estavam de fato engajados com o curso.

Ho produziu o seguinte diagrama para representar os diferentes níveis de engajamento em MOOC. 


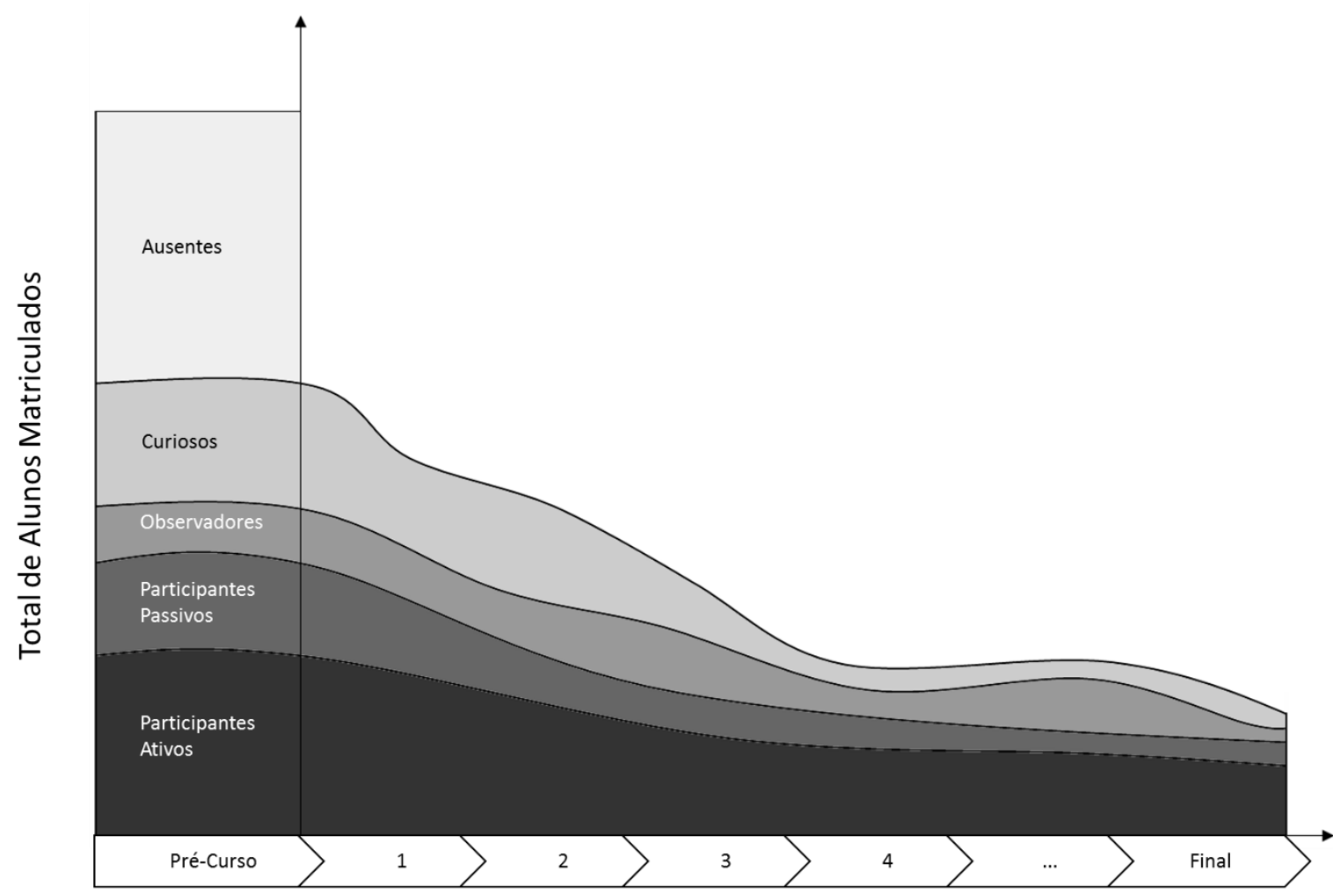

Número de Semanas passadas no MOOC

Figura 8 - Padrões Estudantis emergentes em xMOOC de acordo com diferentes graus de engajamento nos cursos (Ho et al., 2014)

Baseado neste baixo padrão de engajamento, Bates faz uma analogia interessante com a transmissão de programas educativos que já existiram no passado via meios de comunicação em massa como a televisão e rádio:

No centro da esfera está um grupo de estudantes comprometidos que trabalham ao longo de todo o curso e, quando disponível, realizam uma avaliação ao final do curso. Em volta deste centro da esfera está uma segunda camada mais ampla de estudantes que não fazem nenhuma avaliação ao final do curso, mas se inscrevem em uma classe local ou ensino por correspondência. Pode existir até mesmo uma camada ainda maior de estudantes que, além de ver e ouvir as aulas, também compra livros didáticos, mas não se inscrevem em nenhum curso. Depois, de longe o maior grupo, estão aqueles que somente assistem ou ouvem os programas. Mesmo dentro deste grupo pode haver variações daqueles que assistem os programas com regularidade daqueles que só assistem a um ou dois programas. (Bates, 1984)

Esta analogia, que faz referência a esta citação do autor em 1984, nos faz pensar o quanto os MOOC não estariam replicando esta mesma lógica de transmissão massiva que já ocorreu no passado. Se isso for verdadeiro, os MOOC poderiam ser considerados uma contribuição útil para a educação não formal continuada, mas não seriam exatamente algo transformador. A partir desta 
analogia, Bates sumariza os principais pontos fortes e fracos dos MOOC na listagem abaixo (BATES, 2016):

Pontos Fortes:

- Os MOOC, especialmente no formato XMOOC, oferecem um conteúdo de alta qualidade de algumas das mais renomadas universidades do mundo, para qualquer um, em qualquer lugar do mundo com um computador e uma conexão à internet;

- Os MOOC podem ser úteis para dar acesso a conteúdo de alta qualidade, especialmente em países em desenvolvimento, mas para isso requerem uma boa dose de adaptação e investimentos substanciais em suporte local e parcerias;

- Os MOOC são valiosos para desenvolver aprendizagem conceitual básica e para criar grandes comunidades online de interesses e práticas;

- Os MOOC são uma boa forma de promover a aprendizagem contínua por toda a vida;

- Os MOOC forçaram as universidades convencionais, especialmente aquelas de elite, a repensar suas estratégias de aprendizagem online e aberta;

- As universidades tiveram uma boa chance de mostrar suas competências e áreas de especialização para um público mais amplo;

- Uma proposta interessante que pode ser originada a partir dos MOOC envolve a questão de redução de custos da educação, que em algumas camadas como o ensino superior, tem apresentado uma escalada grande de crescimento nos últimos anos.

\section{Pontos Fracos:}

- O número alto de inscrições em MOOC pode ser um tanto ilusório se considerarmos as baixas taxas de engajamento e altas taxas de abandono. Somente uma proporção muito pequena dos inscritos, cerca de 5\%, efetivamente conclui o curso. Entretanto, em números absolutos a quantidade é muito grande;

- Os MOOC tendem a atrair estudantes que já possuem um nível alto de educação formal ao invés de promover mais acesso; 
- A questão da avaliação nos MOOC continua um desafio a ponto dos provedores de MOOC não aceitarem os créditos-aula em seus próprios cursos;

- Os materiais didáticos dos MOOC podem ser limitados se considerarmos as questões de propriedade intelectual - poucos são tratados como recursos educacionais abertos.

Um outro aspecto chave que emerge desta análise crítica é discussão acerca da presença social no ambiente online. Em ambientes de aprendizagem presenciais o senso de pertencimento social é representado pela presença física na turma. Isso acontece porque a comunicação não é mediada - o aluno está em um ambiente de imersão comunicativa com a turma. Em ambientes de aprendizagem virtuais, o desenvolvimento destas capacidades é sempre uma opção para o aluno, já que a comunicação é mediada por artefatos digitais e, a qualquer momento, ele pode simplesmente cortar o meio de comunicação - desligar o aparelho, trocar o canal. Isso não tem necessariamente a ver com a questão da presença social, porque é possível sentir-se presente em ambientes mediados por artefatos tecnológicos. Biocca define a percepção da presença social como:

O nível mínimo de presença social acontece quando os usuários sentem que uma forma, comportamento ou experiência sensorial, indica a presença de uma outra forma de inteligência. $\mathrm{O}$ montante de presença social é o grau que um usuário sente o acesso a inteligência, intenções e impressões sensoriais uns dos outros. (BIOCCA, 1997, página 18)

A questão chave que levantamos aqui nesta discussão é, portanto, a continuidade da comunicação. Fazendo uma analogia, é como se uma turma fosse transferida de uma sala onde acontece uma aula de biologia para um grande centro de exposições com a mesma temática, onde todos os alunos tivessem a liberdade de visitar qualquer estande, a qualquer momento. Como manter a turma coesa em um ambiente destes? Como promover o sentimento de pertencimento social a este grupo, mesmo sabendo que cada um se direcionou para um estande diferente na exposição? O fato de estarem todos vestindo o mesmo uniforme escolar não confere a eles a capacidade de entendimento e não assegura algum tipo de coordenação social para atingir este objetivo. A solução normalmente adotada passa pelo estabelecimento de algum tipo de relação de poder, conferindo a força de coesão do grupo ao professor, ao currículo, ou ambos. Cria-se um roteiro de 
visita na feira e todos permanecem sob a mira do professor, que por sua vez estabelece algum tipo de incentivo para que todos cumpram este roteiro. Práticas orientadas a manter a coesão do grupo não significam necessariamente uma declaração de fracasso no processo de aprendizagem. Eventualmente, dependendo até mesmo do nível de maturidade dos alunos, esta solução pode ser até mesmo desejável.

Os MOOC detêm certa similaridade com o exemplo da feira de biologia, onde os alunos, apesar de fazerem parte da mesma turma, não estão necessariamente no mesmo ambiente ao mesmo tempo. Porém, a prática de forçar a coesão não funciona da mesma forma que na feira - as relações de poder são muito diferentes. Por sua natureza aberta (“O” de Open), a opção de pertencimento ou não ao grupo específico representado pela turma é tão simples como o apertar de um botão. Este fato ficou evidenciado anteriormente neste capítulo através da pesquisa que mostra que cerca de $95 \%$ dos alunos não conclui o MOOC (HO ET AL, 2014). É como se na analogia que fizemos, 95\% dos alunos que entraram juntos no pavilhão da exposição de biologia tivessem abandonado o pavilhão ou concluído somente uma parte do trajeto recomendado pelo professor. Esta é uma situação impensável quando se fala em uma turma presencial - se isso acontecesse de fato, professores nunca levariam alunos em exposições de qualquer natureza. Porém, este é o cenário típico dos cursos MOOC. Passamos agora a discutir a questão da participação e da mediação em cursos online. 


\section{4 \\ Participação e Mediação em Cursos Online}

Passamos agora a descrever os processos de participação e de mediação pedagógica no contexto de EAD, baseados na relação entre os processos de ensino e de aprendizagem. Como citado inicialmente nos objetivos deste trabalho, faremos nos próximos capítulos uma avaliação dos efeitos da inserção de um mediador de fóruns de discussão na participação e desempenho dos estudantes de um curso online. Portanto, cabe agora explorar algumas perspectivas conceituais sobre a participação e mediação pedagógica. Ao mesmo tempo definir quais destas perspectivas estaremos adotando para preparação da pesquisa de campo, análise e discussão dos resultados.

\section{1}

\section{Participação em Cursos Online}

Em uma pesquisa envolvendo 1.406 estudantes de cursos online na Universidade Estadual de Nova Iorque, chegou-se à conclusão que os três elementos que mais contribuíram para a eficácia na aprendizagem, medidos a partir da percepção dos alunos, foram a interação com os professores, os níveis de participação no curso e a interação com os colegas de turma (FREDERICKSEN, et al., 2000). Outro estudo com 354 estudantes de cursos online na Universidade da Geórgia, apontou para uma grande influência da participação dos alunos nos resultados, medidos a partir de um grau final (MORRIS, et al., 2005). Neste último estudo, as variáveis de participação, medidas em termos de frequência (ex.: número de postagens em fóruns) e tempo (ex.: tempo gasto no conteúdo de uma página), explicaram $31 \%$ da variância nos graus finais do curso. Sobre a participação específica em fóruns de discussão, um recente estudo realizado no Brasil com um curso MOOC sobre a Língua Portuguesa, apontou fortes indícios que a participação em fóruns de discussão promoveu um efeito positivo de engajamento na realização de outras atividades do curso (RODRIGUES et. Al, 2016).

Estes três estudos sugerem que a participação, no contexto de cursos online, é um precursor de resultados de aprendizagem. Estudos similares realizados na área apontam para resultados parecidos, também sugerindo a ideia 
de que alunos mais participativos tem melhores resultados em cursos online (DAVIES e GRAFF, 2005). Entretanto, o conceito de participação pode ser um tanto difuso, sem uma definição uniforme, remetendo a diversas formas de interpretação. Três tipos de interação em cursos podem nos servir de guia para o mapeamento das formas de participação em cursos online - a interação alunoinstrutor, aluno-conteúdo e aluno-aluno (MOORE, 1989). As concepções de participação originadas a partir destes três tipos de interação, podem ser observadas em dois níveis diferentes. Concepções de participação online de baixo nível se referem a participação com uma conotação mais quantitativa (ex.: número de vezes que o aluno acessou a plataforma), enquanto as concepções de alto nível enfatizam a perspectiva social da aprendizagem, que incluem eventos mais subjetivos (HRASTINSKI, 2008). Ou seja, segundo a concepção de alto nível, participar significa se juntar a um diálogo para uma aprendizagem engajada e ativa (VONDERWELL e ZACHARIAH, 2005). É mais do que somente o número total de postagens em um fórum de discussão, mas também incluem ela.

Participação de estudantes online é um processo de aprendizagem a partir do protagonismo e manutenção do relacionamento com outras pessoas. É um processo complexo que inclui ação, comunicação, pensamento, sentimento e pertencimento, ocorrendo tanto online quanto offline. (HRASTINSKI, 2008)

Apesar da perspectiva de alto nível ser mais abrangente e, muito provavelmente, ter a capacidade de melhor explicar as nuances da participação, as pesquisas na área tendem a utilizar concepções de participação de baixo nível, baseadas na contagem de frequências como medidas de participação (HRASTINSKI, 2008). Muito provavelmente isso ocorre por questões meramente práticas, associadas a facilidade de coleta de dados quantitativos no ambiente online. A contagem da quantidade de mensagens enviadas, tanto em fóruns de discussão quanto nos sistemas de chat entre alunos, é a unidade de medida mais recorrente nas pesquisas sobre participação. Logo em seguida vem as medidas associadas a esquemas de classificação da qualidade destas mensagens. Em terceiro lugar, vem o uso das percepções dos próprios estudantes sobre a sua participação e de seus colegas no curso. Em quarto lugar, medidas de tamanho das mensagens, normalmente expressas em caracteres. Em quinto lugar, a quantidade de acessos ou logins no ambiente virtual de aprendizagem. Finalmente, em sexto e 
sétimo lugar, respectivamente, estão a leitura das mensagens e o tempo gasto no consumo do material de estudo do curso (HRASTINSKI, 2008).

Todas estas unidades de medida de participação citadas acima estão associadas a uma concepção de participação orientada para aspectos de baixo nível, que podem ser coletados com certa facilidade a partir de dimensões quantitativas. Este tipo de unidade de medida de participação, coincide com o estudo de Parsons e Taylor (2011) que identificou três principais modelos de engajamento, nomeados pelos autores como comportamental, cognitivo e emocional.

O engajamento comportamental está relacionado à noção de participação e é associado a comportamentos mais facilmente observáveis como participação efetiva do estudante nas atividades curriculares e extracurriculares propostas. O engajamento comportamental costuma ser tradicionalmente mensurado a partir de aspectos quantitativos, como: frequência, eficácia e tempo despendido na realização de atividades e notas obtidas em testes. (RODRIGUES et. Al, 2016)

Apesar do questionamento possa emergir acerca da validade $\mathrm{e}$ aplicabilidade deste formato mais quantitativo, a maior parte da pesquisa sobre participação vem sendo feita desta forma. No presente estudo, estaremos adotando uma abordagem similar. Portanto, para efeito de classificação deste trabalho, definimos participação dos alunos em cursos online como o grau de interação com elementos quantificáveis no ambiente virtual de aprendizagem do curso em questão. Exemplos de elementos quantificáveis são todos aqueles que possam derivar medidas de frequência (ex.: quantidade de visualização de videoaulas), medidas de tempo (ex.: tempo de permanência no ambiente virtual de aprendizagem no curso) e medidas de escala (ex.: notas nos exames de avaliação).

Entendemos a importância da utilização de concepções de participação de alto nível, que incluam aspectos associados a socialização dos alunos nos cursos, o sentimento de presença no ambiente virtual de aprendizagem, o grau de comprometimento com a aprendizagem da temática do curso, dentre outros aspectos de que demandam um maior grau de complexidade e abstração. No entanto, o desafio de definição destes conceitos de uma maneira prática e de criação de instrumentos de medida confiáveis, nos fazem optar por seguir a maioria dos pesquisadores e adotar uma definição de participação de estudantes em cursos online a partir de uma perspectiva mais simples e objetiva. 


\section{2 \\ Mediação Pedagógica em Cursos Online}

Peixoto entende que a mediação é um aspecto primordial da psicologia histórico-cultural, caracterizando o fato de que os seres humanos não agem diretamente sobre o mundo. A mediação não estaria somente centrada nos artefatos materiais e tecnológico, mas também na dinâmica dos indivíduos e suas relações sociais.

As ações são mediadas por ferramentas sócio-semióticas (tais como a linguagem ou a matemática), bem como por artefatos materiais e tecnologias. A esse aspecto, soma-se o entendimento de que a mediação se efetiva no bojo dos processos históricos, institucionais e discursivos, constituindo-se pela atividade prática e simbólica de um sujeito. (PEIXOTO, 2011)

Esta ideia é levada a um nível ainda mais alto no aspecto social por Molon que, seguindo a perspectiva Vigotskiana, caracteriza a mediação como um processo. No seu entender, a mediação não está entre dois termos que estabelecem uma relação, pois a mediação seria a própria relação.

A mediação é processo, não é o ato em que alguma coisa se interpõe; mediação não está entre dois termos que estabelece uma relação. É a própria relação. A mediação pelos signos, as diferentes formas de semiotização, possibilita e sustenta a relação social, pois é um processo de significação que permite a comunicação entre as pessoas e a passagem da totalidade às partes e vice-versa. A mediação não é a presença física do outro, não é a corporeidade do outro que estabelece a relação mediatizada, mas ela ocorre através dos signos, da palavra, da semiótica, dos instrumentos de mediação. A presença corpórea do outro não garante a mediação. (MOLON, 2000)

Este argumento em torno da mediação como processo considera as tecnologias de forma mais ampla, como um sistema simbólico construído em torno das relações que se formam. Isso pode causar certa confusão entre as partes "hard" e "soft" deste processo. As TIC são normalmente entendidas como os artefatos, as tecnologias, que estamos nos referindo com a parte "hard". Entretanto, nesta compreensão de mediação como um processo social, o papel das TIC parece não ter um espaço tão claro na mediação. Estariam elas de fato inseridas na mediação? Seriam elas os elementos chave da mediação? Grande parte da literatura internacional sobre o tema de mediação se sobrepõe com o conceito de mídia (no sentido "hard"). Para evitar esta confusão, Daniel Peraya faz uma interessante proposta de separar os processos de midiatização e mediação (PERAYA, 2006). No seu entender, estes processos fazem referência a objetos 
distintos. A midiatização trataria de forma específica dos dispositivos de comunicação, que poderíamos entender como as mídias, ou seja, as TIC propriamente ditas. No contexto de EAD, estaríamos falando do ambiente virtual de aprendizagem, suas funcionalidades e todo desenho instrucional (design) projetado para o curso. Trata-se de observar, de analisar e de compreender os efeitos dos dispositivos midiáticos, dos instrumentos sobre os comportamentos cognitivos e relacionais. (PERAYA, 2006)

Essa distinção tem o papel de lembrar que todo ato pedagógico, assim como qualquer ato de comunicação, comporta um importante aspecto relacional. A relação pedagógica pode ser objeto de midiatização. Mas essa distinção implica em uma ambiguidade: os processos de mediação cognitiva, que dizem respeito, particularmente, às características próprias das mídias, como o impacto dos sistemas de representação sobre os processos de aprendizagem, encontram-se, assim, relegados à dimensão da midiatização, impondo dificuldades teóricas e metodológicas. (PEIXOTO, 2011)

Uma das características dos cursos online e das tecnologias de informação e comunicação, de forma geral, é o seu potencial de convergir diferentes componentes, meios e funções. Esta convergência fica explícita no ambiente virtual de aprendizagem e a figura do mediador serve como um elemento de referência e ação para o estudante, podendo-se assim considerar que a mediação é um elemento da relação pedagógica. Prado defende a ideia de uma educação à distância orientada para a proximidade entre os participantes do curso, enfatizando o acompanhamento e a orientação constante do professor nas diversas situações de aprendizagem dos alunos. Segundo a autora, esta abordagem - o estar junto virtual - tem norteado os grupos de docentes e pesquisadores no desenvolvimento de cursos de formação de professores para o uso pedagógico da informática

\begin{abstract}
Nessa perspectiva, as ferramentas computacionais do ambiente virtual não se restringem a serem um meio de viabilização do curso, elas também podem e devem ser integradas nas estratégias da mediação pedagógica. Consequentemente, isto implica repensar a mediação pedagógica considerando os elementos constituintes do contexto de um curso (os materiais, as atividades e as interações) e as novas possibilidades de ampliação que ocorrem por meio da integração das ferramentas computacionais do próprio ambiente virtual. Essa integração, portanto, permite o redimensionamento da mediação pedagógica, evidenciando aspectos próprios da educação a distância, que potencializam uma nova forma de ensinar e de aprender. (PRADO, 2006)
\end{abstract}

Masetto traz uma perspectiva similar, ao afirmar que a mediação pedagógica é a atitude, o comportamento do professor que se coloca como um incentivador ou 
motivador da aprendizagem, como uma ponte rolante entre o aprendiz e a aprendizagem, destacando o diálogo, a troca de experiências, o debate e a proposição de situações (MASETTO, 2000). A partir desta perspectiva que foi construído o papel do mediador no curso objeto deste estudo. Entendemos que em ambientes virtuais de aprendizagem, esta atuação se faz não somente para os aspectos didáticos de conteúdo do curso como também para o uso da ferramenta tecnológica em si. O mediador tem um papel importante ao favorecer o diálogo e a participação ativa dos estudantes, a partir de suas estratégias de interação didática. Na perspectiva do estudantes e professores, a utilização das TIC demanda tanto o desenvolvimento de capacidades de operação das ferramentas e dispositivos de comunicação (smartphones, fóruns, chats e outros serviços de mensagem) quanto a promoção da interação e colaboração entre os participantes - momento este da construção participativa do conhecimento. Entretanto, cada um destes dispositivos exige habilidades mediadoras diferenciadas que, naturalmente, podem originar diferentes estratégias pedagógicas.

No capítulo seguinte faremos uma descrição da pesquisa de campo realizada, mas adiantamos aqui nesta seção a forma como fizemos a seleção e preparação do mediador para atuar na moderação dos fóruns de discussão realizados durante o curso que foi base para a pesquisa de campo.

A seleção do mediador partiu das seguintes premissas:

i. Experiência prévia com mediação, tutoria, suporte e/ou geração de conteúdo para cursos em ambientes virtuais de aprendizagem. A formação para atuação em cursos online pode ser um tanto complexa e demorada, por isso optamos por buscar um mediador que já fosse experiente neste tipo de ambiente, linguagem e recursos. $\mathrm{O}$ treinamento do mediador se limitou a algumas seções de orientação em relação ao formato de ação durante o curso;

ii. Experiência com fóruns de discussão. A atuação do mediador foi diretamente nos fóruns de discussão. Portanto, uma segunda premissa é que o candidato a mediador também tivesse uma experiência específica com moderação de debates em fóruns de discussão online.

iii. Perfil de proatividade. O mediador teve uma atuação ativa nos debates, exigindo uma postura segura e confortável de interferir no discurso, mesmo não sendo necessariamente um especialista no tópico do curso. 
A partir destas premissas preparamos uma listagem, por conveniência, de pessoas ligadas a rede da PUC-Rio, que poderiam desempenhar este papel. Após realizar alguns convites e conversar com possíveis candidatos, selecionamos uma funcionária da própria $\mathrm{CCEAD}$, com muita experiência com ambientes virtuais de aprendizagem e o perfil proativo, necessário para atuar no papel de mediação. Sua experiência com ambientes virtuais de aprendizagem é de cerca de cinco anos, incluindo funções de suporte, tutoria, desenho instrucional, geração de conteúdo digital e moderação de fóruns de discussão.

Após a seleção, fizemos algumas reuniões de orientação com a mediadora para descrever os objetivos do curso e sua forma de atuação junto aos participantes do curso. Além disso, desenvolvemos uma ferramenta digital que foi inserida nos fóruns de discussão do curso, cujas funcionalidades permitam que o mediador fornecesse um feedback bastante objetivo (1-clique) a partir das postagens dos participantes. Sendo assim, acreditamos que o mediador eleito para participar da pesquisa detinha as devidas qualificações. A figura a seguir ilustra esta ferramenta de feedback. Cabe destacar que esta ferramenta era somente uma forma adicional de interação para a mediadora. Ela não perdeu ou foi desencorajada a postar suas interferências no debate em formato de texto. Pelo contrário, sua principal fonte de interação foi através de mensagens postadas no fórum de discussão online.

3. Re: Bitcoin é ou nào é dinheiro?

Mas servir como forma de investimento, pra ti, năo serve como "moeda"? Por que essa distinç̧ơ?

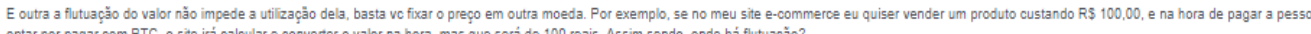
De 0 sine irá calcular e converter o valor na hora, mas que será de 100 reais. Assim sendo, onde há flutuaçăo?

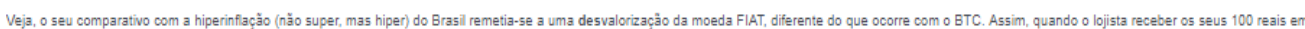

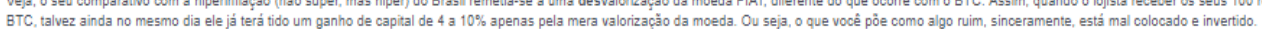

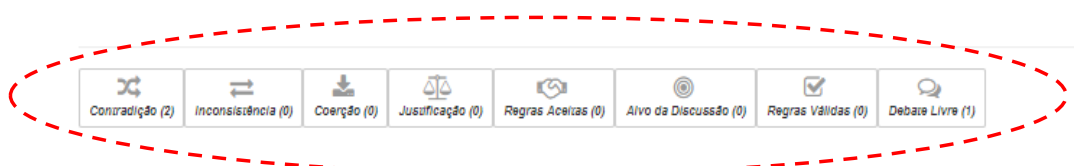

Figura 9 - Ferramenta de Feedback para o Mediador nos fóruns de discussão do curso

Passamos agora ao próximo capítulo que trata da descrição metodológica da pesquisa aplicada, além de descrever todo processo de criação do MOOC, a execução do curso, a coleta de dados, preparação das bases, tratamento e análise dos resultados. 


\section{5 \\ Metodologia}

\section{1}

\section{Linha de Pesquisa}

A metodologia adotada segue uma linha pesquisa exploratória quantitativa, utilizando técnicas de análise estatística. Seguindo a classificação de Vergara (1991), uma pesquisa pode ser dividida em relação à intenção (fins) e os meios de investigação. Com relação à intenção, é uma pesquisa descritiva porque tenta descrever as características de uma população (participantes do curso) e tenta estabelecer relações entre certas variáveis definidas. Com relação aos meios, é uma pesquisa de campo na linha experimental, mas seria melhor definida como quasi-experimental, já que não trabalhamos com uma amostra não probabilística. É uma pesquisa de campo porque a investigação será realizada no local onde ocorre o fenômeno e que dispõe dos elementos para poder explicá-lo - no nosso caso, o local será o próprio ambiente virtual online do curso. É experimental porque é uma investigação empírica na qual faremos a manipulação e controle de variáveis independentes com o objetivo de observar as variações que tal manipulação e controle produzirão em algumas variáveis dependentes. Neste sentido, as intervenções no ambiente do curso nos permitirão observar e analisar o fenômeno sob condições determinadas.

\section{2}

\section{Universo e Seleção da Amostra}

O Universo da educação online no Brasil é composto de alunos que frequentam basicamente dois tipos de curso: os cursos regulamentados e os cursos livres. Os cursos regulamentados são tipicamente aqueles oferecidos por instituições de ensino cadastradas no MEC, com ofertas de cursos nas modalidades totalmente à distância ou semipresenciais, com contagem de crédito para fins de emissão de diplomas. Já os cursos livres, são oferecidos por instituições públicas e privadas, cadastradas ou não no MEC, com ofertas de cursos nas modalidades totalmente à distância ou semipresenciais, sem contagem 
de crédito para fins de emissão de diplomas. Segundo o censo ABED para o ano de 2015, foram contabilizadas 5.048.912 matrículas nos cursos online no Brasil, somadas as modalidades regulamentos e livres. As duas figuras abaixo ilustram e fornecem mais detalhes sobre o universo de pesquisa.

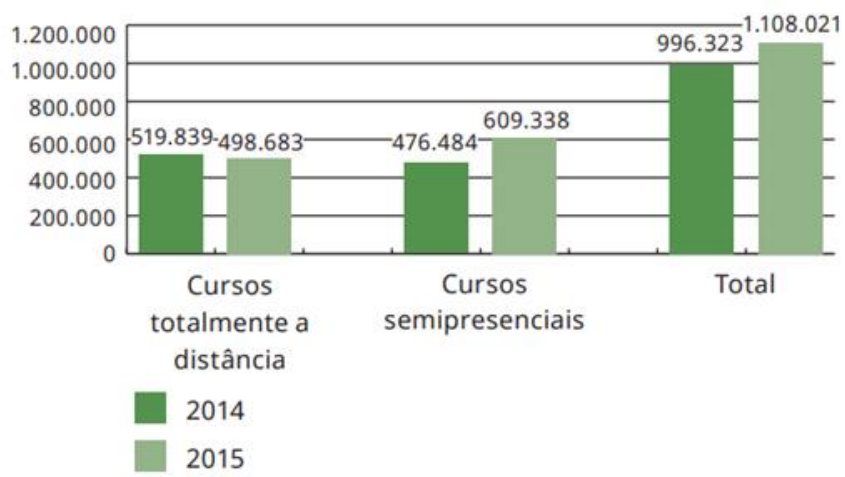

Figura 10 - Matrículas em cursos regulamentados totalmente a distância ou semipresenciais, segundo o censo EAD.BR do ano de 2015 (em números absolutos)

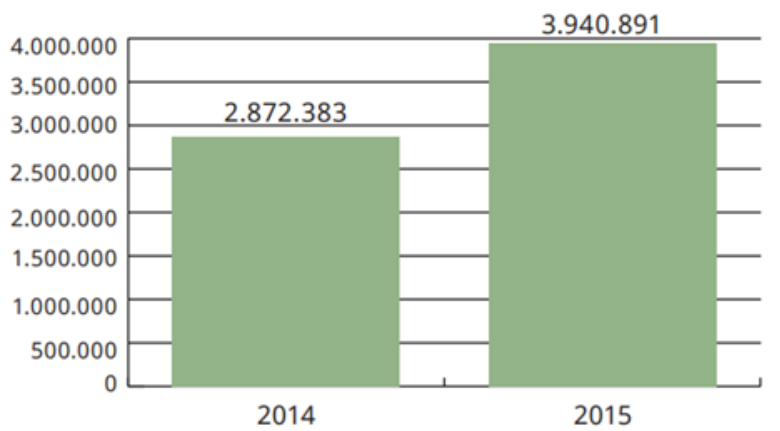

Figura 11 - Matrículas em cursos livres, segundo o censo EAD.BR do ano de 2015 (em números absolutos)

O número real de brasileiros matriculados em cursos online certamente é maior do que este apontado pela $\mathrm{ABED}$, considerando que existem muitos cursos no exterior que dão acesso a alunos de todo mundo, mas que não foram contabilizados nesta pesquisa. Por outro lado, parte desta falta de contabilização é amortecida pelas inscrições de alunos estrangeiros em cursos brasileiros que foram contabilizados. Acreditamos que este número não seja tão grande quanto o primeiro caso, mas já ajuda a reduzir a distorção. De qualquer maneira, este número "mínimo" de alunos matriculados nos cursos online no Brasil já dá uma dimensão do universo que estamos trabalhando nesta pesquisa. 
Dentro deste universo de alunos, trabalhamos com uma amostra não probabilística, dentro de um ambiente próprio de um curso livre, com um tópico específico na área de tecnologia e aberto para o público sem pré-requisitos de entrada. Portanto, a amostra que utilizamos na pesquisa, foi composta especificamente por alunos deste curso de tecnologia, oferecido em conjunto pela $\mathrm{CCE}^{19}$ e $\mathrm{CCEAD}^{20}$ da PUC-Rio e que, no momento da matrícula, estiverem de acordo em compartilhar seus dados sejam utilizados para pesquisa - naturalmente mantendo seu anonimato e preservando as regras e diretrizes aprovadas pela comissão de ética e pesquisa da PUC-Rio. Trata-se, portanto, de uma seleção por conveniência, neste caso expressa pela livre escolha dos alunos de participar ou não do curso.

A unidade de análise é o aluno e seus registros de participação (atividades do curso) que foram arquivados em uma base de dados do curso, armazenada no $\mathrm{RDC}^{21}$ e acessível a partir de ferramentas de pesquisa tipo Query. Todo material do curso foi disponibilizado em português, idioma oficial nos fóruns de discussão. Registramos a presença de alguns alunos internacionais, mas estes vinham de países de língua portuguesa, portanto, não houve nenhum registro no curso em idioma outro que não o português. O mesmo vale para recursos adicionais do curso, tendo em vista que o curso disponibilizou como recurso adicional alguns links para filmes no tema que foi discutido. Os registros associados a estes filmes estrangeiros não foram utilizados para fins da pesquisa.

Ao final, o curso teve 1.200 alunos inscritos. Deste total realizamos selecionamos 565 como amostra para a pesquisa. O procedimento de seleção é descrito posteriormente no item de tratamento de dados.

\footnotetext{
${ }^{19}$ A CCE (Coordenação Central de Extensão) é o órgão responsável na PUC-Rio pela oferta de cursos de extensão na PUC-Rio e pode ser acessada através do site www.cce.puc-rio.br.

20 A CCEAD (Coordenação Central de Educação a Distância) é o núcleo de tecnologias educacionais da PUC-Rio. Ao atuar em Ensino, Pesquisa e Extensão, a CCEAD desenvolve e implementa práticas voltadas para auxiliar professores e alunos a estender as possibilidades do aprendizado. Desse modo, torna possível a propagação de saberes sem os limites de tempo e espaço. A CCEAD também participa da criação e implementação de novos modelos pedagógicos e recursos educacionais para a modalidade a distância e apoio ao presencial. Além disso, elabora cursos de extensão, graduação, especialização e corporativos, visando à formação e capacitação de públicos diversos em todas as regiões do país, com a mesma excelência da universidade.

${ }^{21} \mathrm{O}$ RDC é um Órgão de Apoio da Universidade, subordinado à Vice-Reitoria para Assuntos Acadêmicos, que provê serviços de informática e de comunicação de dados, em apoio às atividades acadêmicas e administrativas da Universidade.
} 


\section{3 Pesquisa de Campo}

O curso online utilizado na pesquisa de campo foi lançado na internet em outubro de 2017, com início marcado para novembro do mesmo ano e duração prevista de três semanas no programa. Seguindo a taxonomia descrita no capítulo 3 , o curso pode ser classificado conforme a tabela a seguir:

\begin{tabular}{|c|c|}
\hline Nome & Introdução às Criptomoedas \\
\hline Identificação Numérica & CCE13173 \\
\hline Autores & $\begin{array}{c}\text { Luís Felipe Carvalho } \\
\text { Felipe Van de Sande Araújo } \\
\text { David Gibbin }\end{array}$ \\
\hline Insti tuição & PUC-Rio \\
\hline Plataforma & Moodle \\
\hline Idioma Primário & Português \\
\hline Domínios & Informática e Economia \\
\hline Nível & Ensino Superior \\
\hline Acreditação & - \\
\hline Certificação Institucional & Não \\
\hline Transferência de Créditos & xMOOC \\
\hline Tipologia &
\end{tabular}

Quadro 10 - Classificação Taxonômica do MOOC de Introdução às Criptomoedas

Inicialmente cabe uma ressalva em relação a escolha pelo formato xMOOC. Ao longo deste trabalho demos grande destaque ao formato original dos MOOC, a partir da experiência de Siemens e Downes, identificado como cMOOC. A ideia inicial era rodar a pesquisa de campo tendo como base este formato Conectivista. Entretanto, alguns fatores foram determinantes para a adoção do formato xMOOC. O primeiro deles é a restrição temporal. Para se aplicar um cMOOC a janela de tempo deveria ser bastante larga, não sendo viável dentro das restrições de tempo aplicadas ao cronograma de confecção de uma Tese de Doutorado. O segundo fator foi a dificuldade de coleta de dados em ambientes distribuídos. Considerando que ainda não existe um ambiente virtual de 
aprendizagem projetado especificamente para o formato cMOOC, este tipo de curso acontece na prática usando plataformas e funcionalidades distintas. Isso tornaria extremamente complexa a tarefa de coleta de dados para a equipe de pesquisa. Por último, um terceiro fator que contribuiu para a adoção de um formato $\mathrm{xMOOC}$, foi o simples fato que a grande maioria dos dados comparativos de pesquisa é baseada neste formato. Poucos foram os cursos cMOOC e poucos são os dados sobre eles. Além disso, por sua maior dificuldade de aplicação, os cMOOC ainda são uma promessa teórica. Os próprios autores deste trabalho tiveram a oportunidade de cursar em 2016 um cMOOC organizado por George Siemens e observar as dificuldades na organização e conclusão do curso.

Com relação ao tema ${ }^{22}$, este foi selecionado devido ao seu potencial de atração de uma quantidade grande de alunos em um espaço curto de tempo, utilizando somente canais gratuitos de divulgação, especialmente as mídias sociais - que tem grande potencial de propagação da peça de divulgação. Além disso, a PUC-Rio é pioneira na oferta de cursos neste tema de Criptomoedas. Em 2016 foi lançada para alunos da graduação, uma disciplina eletiva neste tema, através do domínio adicional de empreendedorismo (código EMP1120). Em 2017 foram ofertadas mais duas turmas na graduação (EMP1116), além de uma outra turma no programa de pós-graduação do departamento de administração de empresas da PUC-Rio. Em paralelo, foram ofertadas mais oito turmas abertas na modalidade de extensão através da CCE (Coordenação Central de Extensão), neste mesmo ano de 2017. Também foram realizados dois ciclos de palestras no tema, como iniciativas da Agência de Inovação da PUC-Rio (AGI) e do Laboratório de Engenharia de Software (LES) do Departamento de Informática. Portanto, já existia um ecossistema favorável a este tópico dentro da PUC-Rio e isso é importante para conferir certa credibilidade a um curso aberto online no tema, no que tange aspectos de divulgação do curso.

22 "Introdução às Criptomoedas" 
O procedimento de matrícula no curso foi realizado através do site da CCE'Puc-Rio, representado parcialmente na impressão de tela feita na figura a seguir.

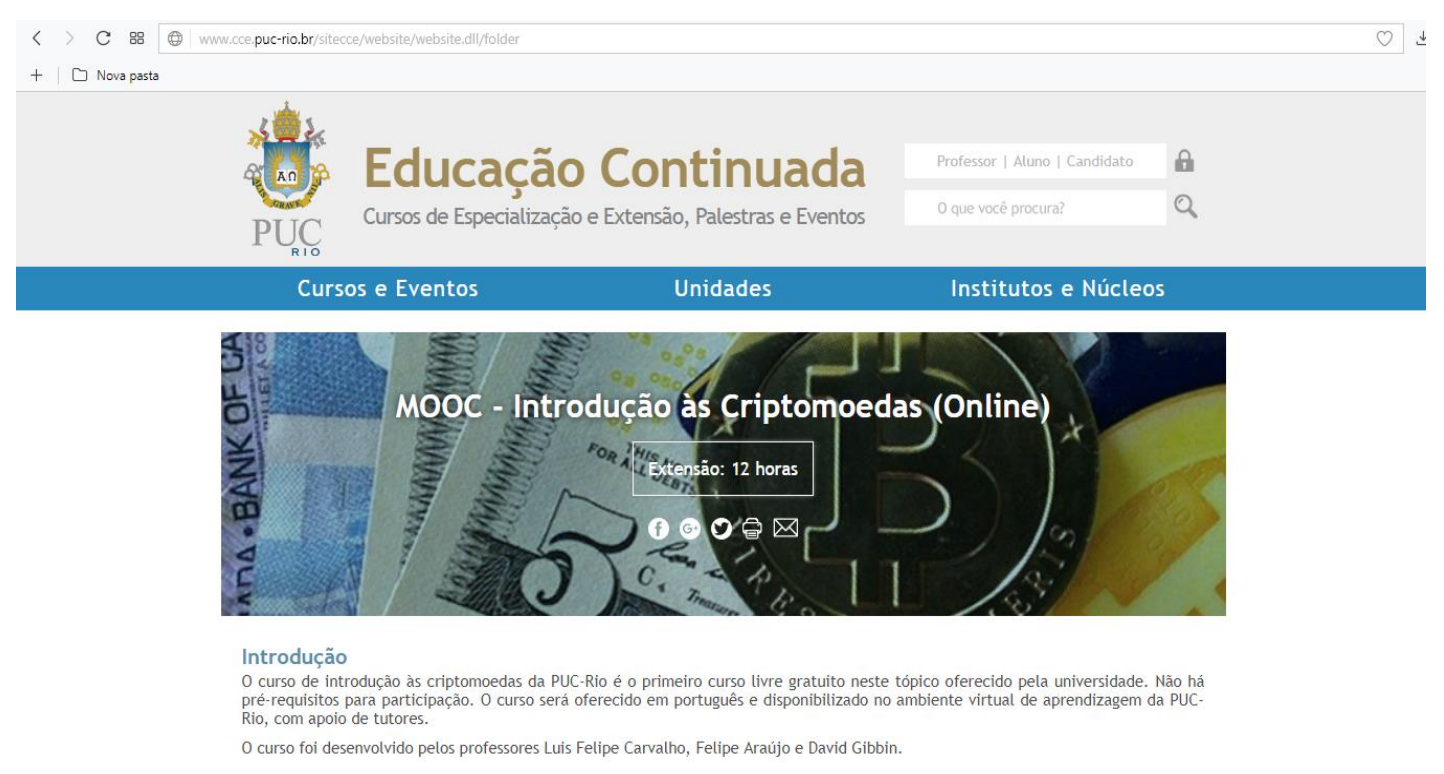

Inicialmente foram alocadas 1.000 vagas no sistema, que se esgotaram em 72 horas, fazendo com que o sistema abrisse automaticamente um recurso de fila de espera, antes de desabilitar o botão de inscrição e finalizar a possibilidade de novas inscrições. Para acomodar as pessoas que ficaram na fila de espera foram abertas mais 200 vagas no curso, totalizando assim 1.200 alunos matriculados no curso. A partir deste momento os alunos matriculados foram direcionados para o Ambiente Virtual de Aprendizagem da CCEAD.

A plataforma base do curso foi o Moodle, onde os alunos receberam as orientações iniciais sobre o funcionamento do curso, o material de estudo, os fóruns de debate, as avaliações e recursos adicionais de apoio. Os servidores do RDC ficarão responsáveis por prover o acesso ao curso via internet e pelo armazenamento dos registros de navegação dos alunos durante o período do curso. 
Os alunos que acessaram a plataforma online do curso, visualizavam um pequeno texto introdutório e tinham como primeiro passo responder ao "Termo de consentimento livre e esclarecido para pesquisa online". Este documento foi aprovado pela Comissão de Ética e Pesquisa da PUC-Rio e o seu texto descrito está na íntegra no Anexo III. Dentro do ambiente do curso, esta tela com o termo de consentimento de pesquisa está representada na figura a seguir. Conforme podemos ver na figura a seguir, o termo de consentimento era o único menu disponível na página principal do curso. Portanto, esta era a sua única opção de escolha.

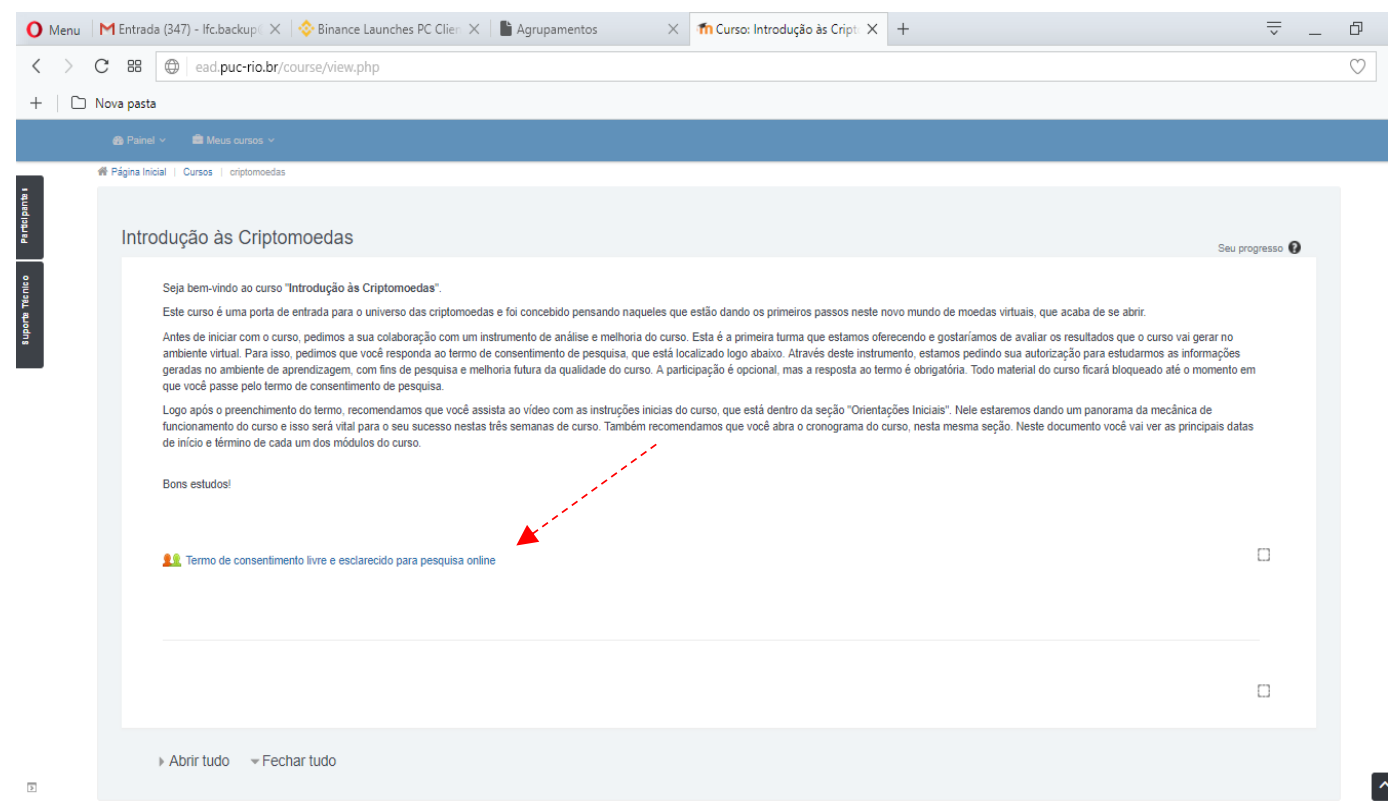

Figura 13 - Tela da página inicial do curso de Introdução às Criptomoedas

Após clicar na opção, o participante tinha acesso a tela do termo, representada na figura a seguir. Feita a leitura do termo, o participante do curso deveria realizar a sua escolha de autorizar ou não o uso de seus dados, de forma anônima, para fins de pesquisa. 


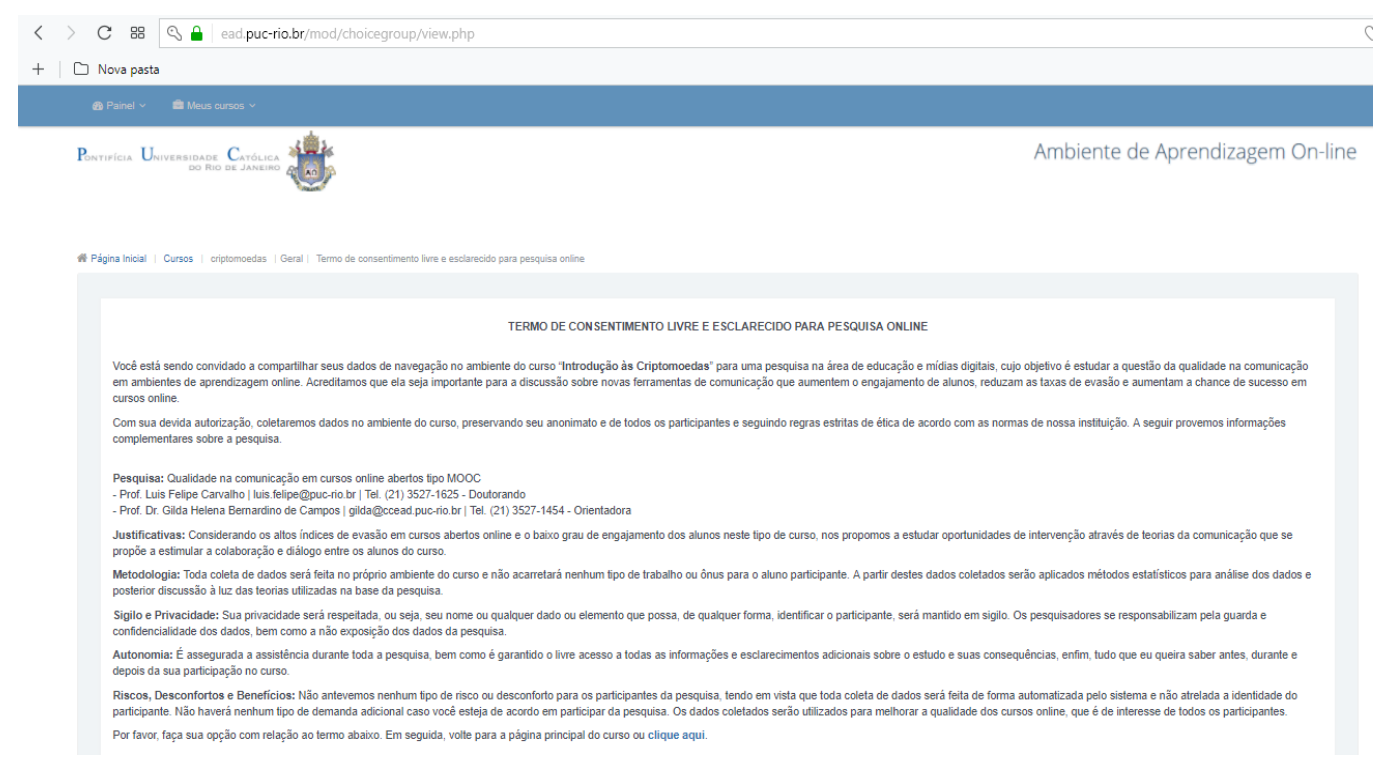

Figura 14 - Tela com o termo de consentimento livre e esclarecido para pesquisa online

As duas opções de resposta eram mutuamente exclusivas, portanto, não existia a possibilidade de um participante marcar as duas opções. No momento que ele fizesse sua escolha, poderia retornar a página principal do ambiente de aprendizagem e encontraria disponibilizado acesso a todo material do curso. Entretanto, se o participante por algum motivo retornasse à página principal do curso sem marcar uma das alternativas, ele não encontraria nada além da opção de responder ao termo de consentimento de pesquisa. A figura a seguir é a impressão da tela com as opções de resposta para o termo.

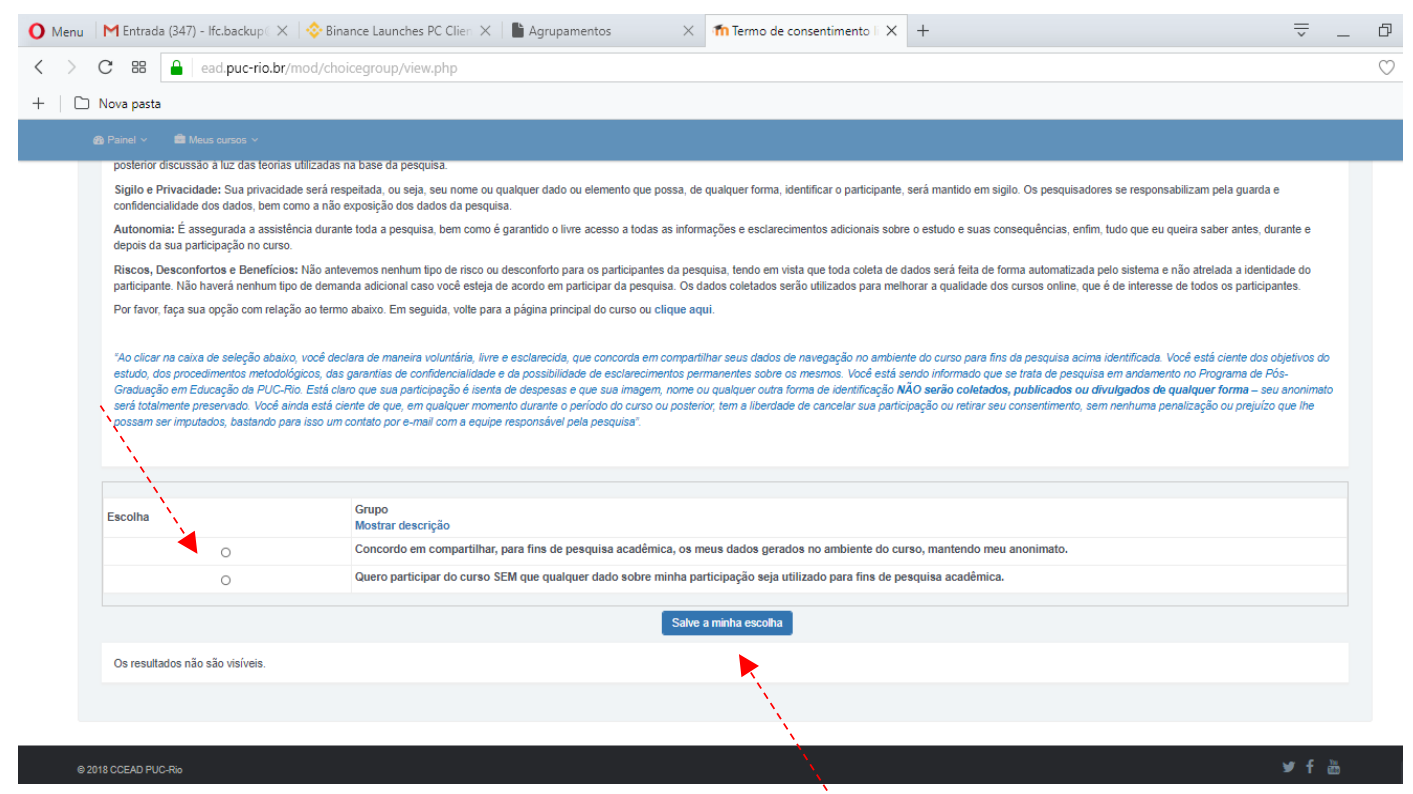

Figura 15 - Tela com as opções de resposta ao termo da pesquisa 
Se o participante concordasse com os termos da pesquisa ele deveria escolher a primeira alternativa na caixa de seleção com botões radiais. Caso ele discordasse, deveria selecionar a segunda alternativa. Feito isso, ele poderia prosseguir para a página na inicial do curso e, independente da sua escolha, todo material do curso estaria disponibilizado, conforme impressão parcial de tela na figura a seguir.

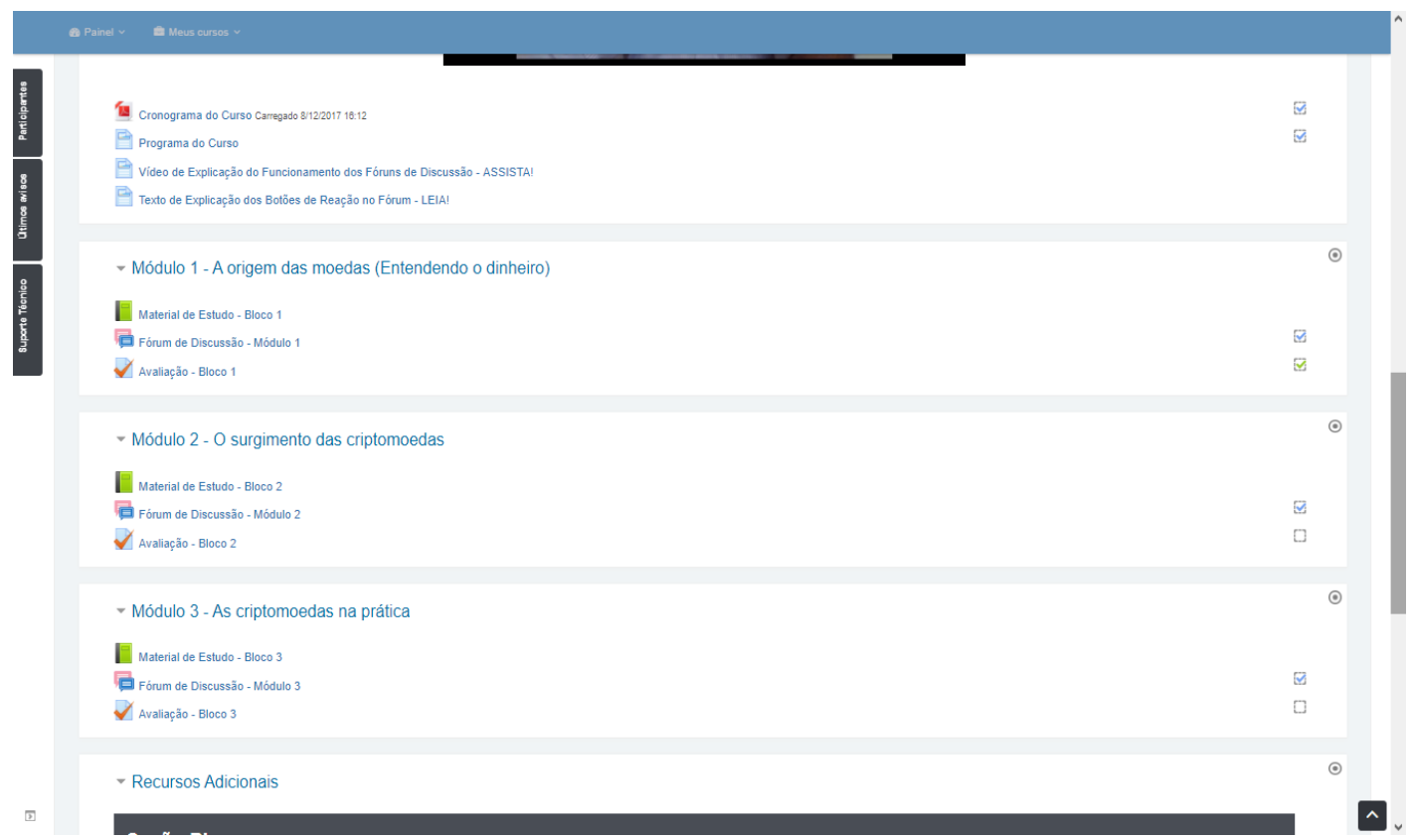

Figura 16 - Tela principal do curso após escolha do Termo de participação na pesquisa

A partir deste ponto, o curso pode ser resumido em três grandes blocos:

- Instruções Iniciais (programa do curso, cronograma, fórum de apresentação dos participantes do curso, vídeo com a explicação da mecânica do curso e vídeo de instruções sobre a participação nas discussões nos fóruns)

- Material de Estudo (bloco dividido em três módulos, cada uma delas contendo videoaulas, fórum de discussão sobre o tema da seção, uma hora de seminário ao vivo com os professores e exame de avaliação da seção)

- Recursos Adicionais (conteúdo que não faz parte da avaliação, mas está ligado ao tema do curso - estudo opcional) 
A maior parte do conteúdo do curso está presente no bloco de material de estudo. É também neste bloco onde foram gerados a maioria dos registros de navegação dos participantes, pois engloba tanto as variáveis associadas ao engajamento do aluno no curso (videoaulas e fóruns), quanto as variáveis de desempenho do aluno no curso (resultado da avaliação). Reforçando a explicação do parágrafo anterior, a seção de material de estudos foi dividida em três módulos com temas de estudo distintos e organizado em torno dos seguintes recursos educacionais digitais (RED):

- Videoaulas

- Fóruns de Discussão

- Seminários ao vivo

- Questionários de Avaliação

Exploramos agora um panorama de cada um destes RED utilizados no MOOC de Introdução às Criptomoedas. As videoaulas foram gravadas pelos três professores do curso. Cada um deles ficou responsável por um dos módulos. No total foram produzidos 22 vídeos, cada um deles contendo em média 10 minutos de aula. Ou seja, o tempo total de duração dos vídeos foi de aproximadamente 220 minutos. O formato das videoaulas seguiu um padrão tipo slides narrados. O professor realizava uma explicação falada enquanto passava slides com imagens e algumas animações, conforme exemplificado na figura a seguir.

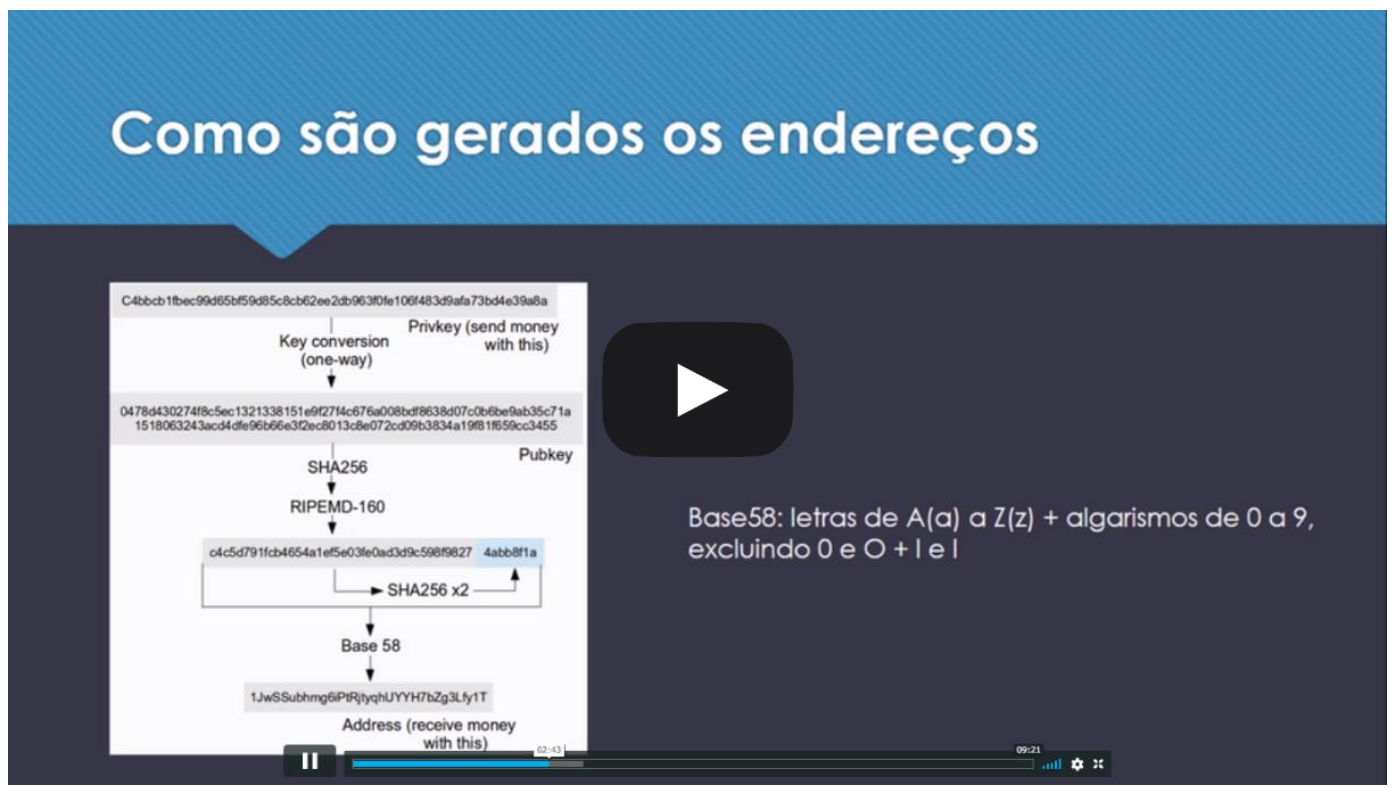

Figura 17 - Exemplo de formato de uma videoaula do curso 
Na primeira semana de aula só estava disponível o material de estudo do módulo 1. O participante conseguia enxergar que haviam mais dois módulos no curso, porém o conteúdo destes estava bloqueado para acesso. A liberação de conteúdo era feita de acordo com o cronograma do curso, que inicialmente previa um módulo de estudo por semana. Este cronograma teve que sofrer uma pequena revisão devido ao agendamento dos seminários com transmissão ao vivo com os professores e, na prática, cada módulo acabou durando 10 dias. Essa se demonstrou uma das vantagens da experiência online - a possibilidade de adaptação de forma simples do cronograma ao longo do curso.

Os fóruns eram liberados sempre dois dias depois da liberação dos vídeos. Por exemplo, se o material de estudo do módulo 2 foi liberado em um sábado, o fórum de discussão seria aberto na segunda-feira. Cada módulo tinha somente um fórum de discussão e este sempre iniciava com um enunciado criado pelo professor do módulo e eventualmente algum material suplementar de estudo. Este enunciado era automaticamente enviado pela plataforma do curso para a caixa de e-mail dos alunos, que ali tinham acesso ao link do fórum e eram convidados a participar com suas opiniões. A figura a seguir mostra a tela referente ao enunciado do fórum de discussão do módulo 1.

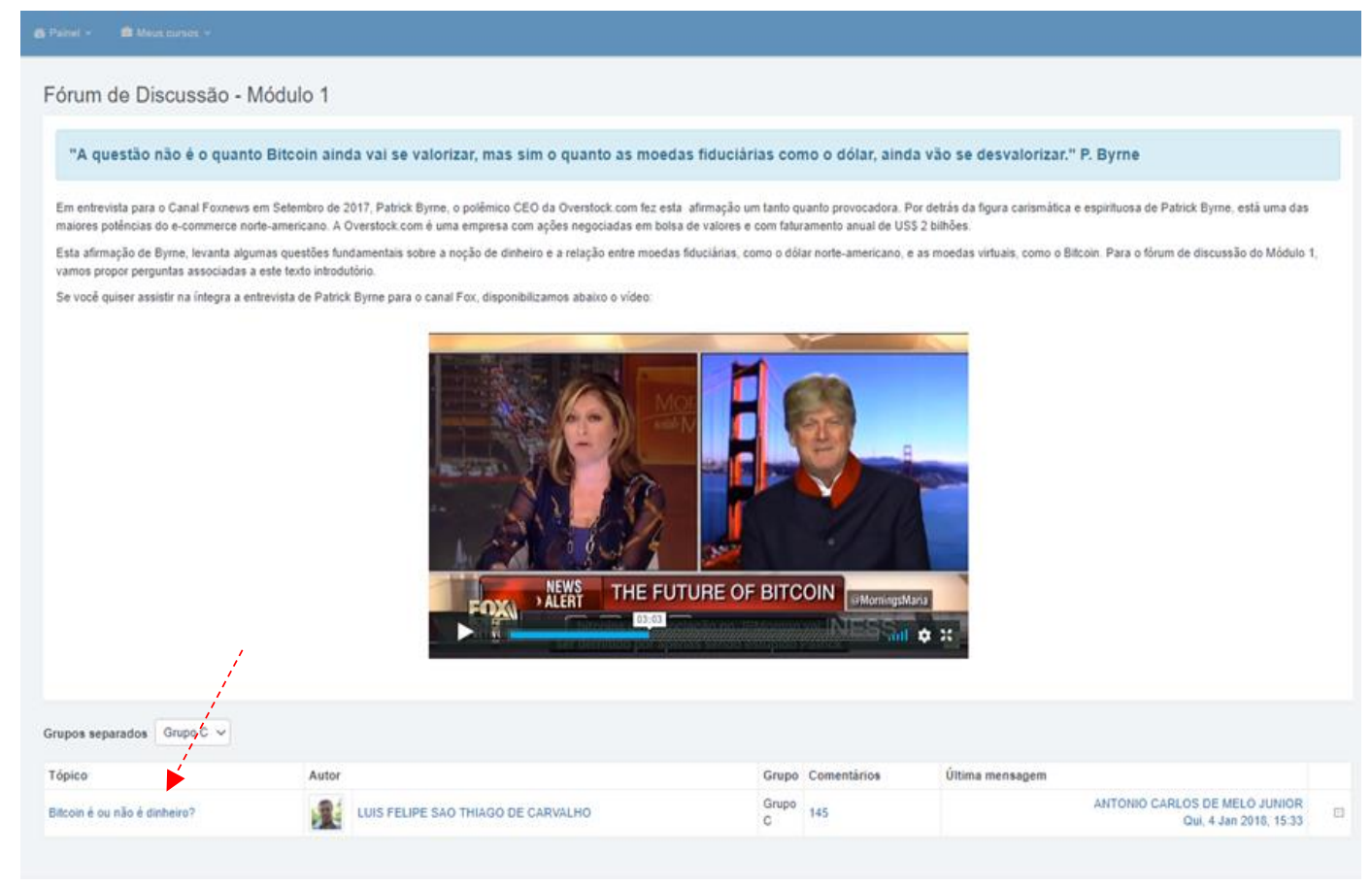

Figura 18 - Tela referente ao enunciado do Fórum de discussão do módulo 1 
A seta sobreposta na imagem indica a pergunta específica feita pelo professor para a turma. Esta pergunta, refere-se ao enunciado dado no fórum e funciona como uma espécie de recorte para a discussão - um tema de debate. Quando os alunos clicavam nesta pergunta feita pelo professor, eles eram direcionados para a área de discussão do fórum, onde efetivamente podiam colocar suas opiniões e postar para a turma. A figura a seguir apresenta um recorte do espaço de debate do fórum do módulo 1, que totalizou 145 comentários.

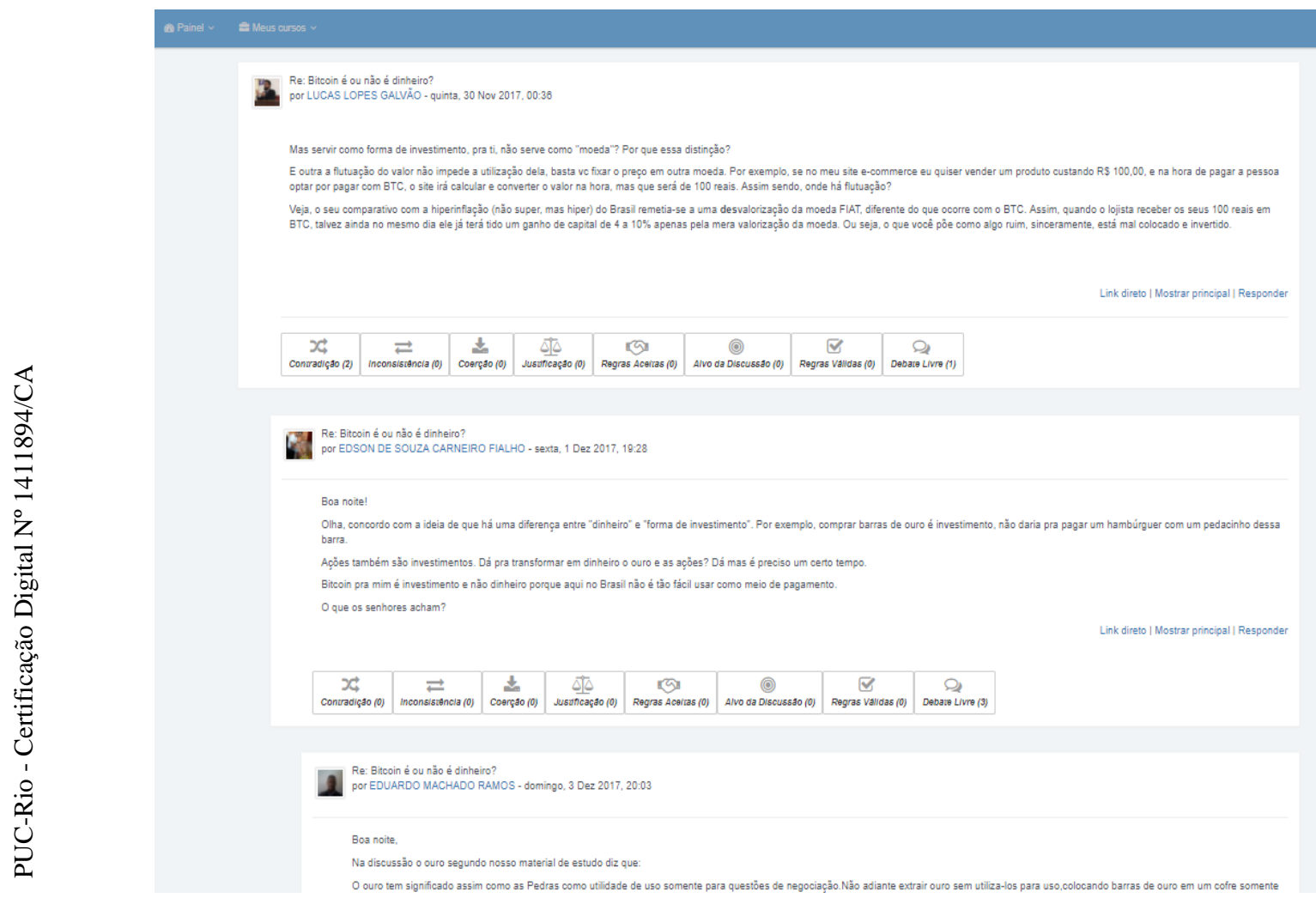

Figura 19 - Tela de exemplo com trecho da discussão no Fórum do módulo 1

Os seminários ao vivo foram realizados através do recurso de vídeo da plataforma Facebook, conhecido como "Facebook Live". Este recurso permite que uma pessoa inicie uma transmissão ao vivo de um vídeo a partir de um dispositivo móvel como um tablet ou telefone celular. No caso do curso, estas transmissões foram feitas a partir de um grupo fechado no Facebook, com hora marcada. Os alunos foram convidados a partir da plataforma do curso a se cadastrar neste grupo e acessar o mural do grupo no horário agendado para o seminário. Fazendo isso, a Live aparecia automaticamente a partir do momento que os professores do 
curso iniciassem a transmissão. As figuras abaixo ilustram a chamada na página do grupo e uma impressão da tela no meio de uma das sessões ao vivo.

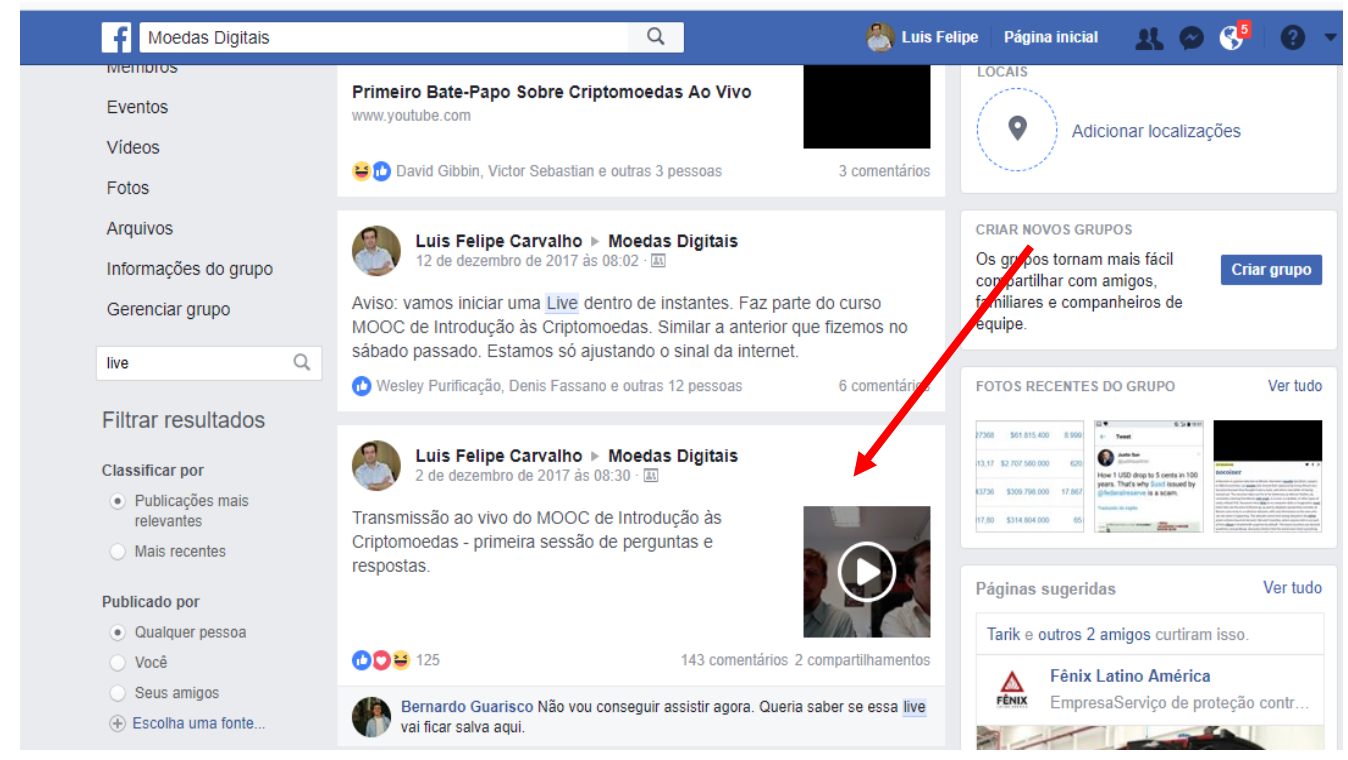

Figura 20 - Chamada para a Facebook Live dentro de página de grupo fechado no Facebook

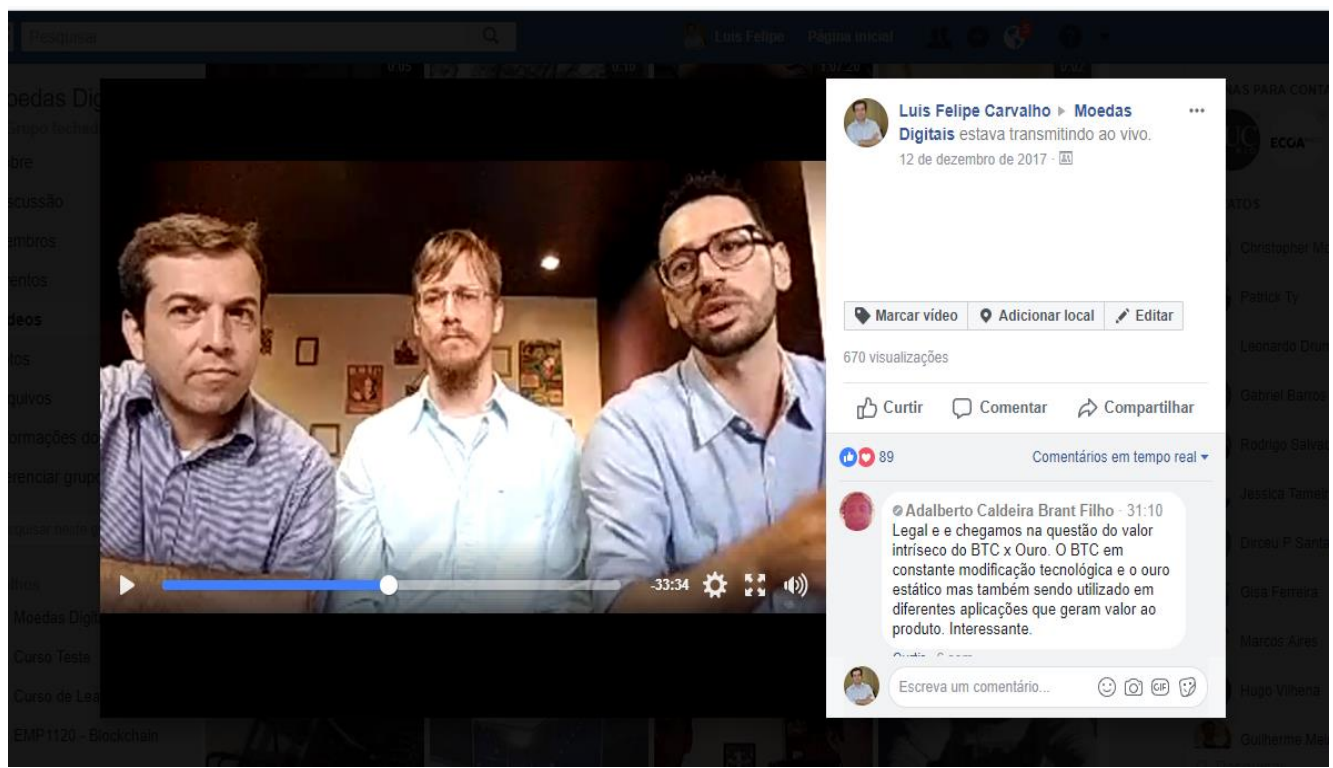

Figura 21 - Impressão de Tela de trecho da terceira transmissão ao vivo com os professores do curso (Facebook Live)

Como pode-se notar na imagem, esta transmissão teve alcance de 670 visualizações, entretanto, no momento da transmissão ao vivo, estavam presentes cerca de 40 participantes. Como como o vídeo fica público no Facebook, ele continua sendo distribuído mesmo depois do término da transmissão. Inclusive, pessoas externas ao curso poderiam participar do seminário ao vivo e interagir. 
Isso dificultou a coleta de dados, tendo e vista que tanto os dados de visualizações quanto de interações via curtidas ou postagens, pode ter sido influenciado por pessoas que não eram participantes do curso. Sendo assim, decidimos não utilizar estes dados na pesquisa, mas fica o registro deste recurso que foi utilizado ao longo do curso e ao que tudo indica, foi uma ferramenta bastante útil no contexto do MOOC.

Por último, as avaliações de desempenho dos alunos no curso foram feitas através de um exame. Este exame acontecia dentro do próprio ambiente do curso, onde o aluno era exposto a um questionário com multiplicas opções de escolha na resposta. O questionário era autoexplicativo e com correção automática pela plataforma do curso. A figura a seguir ilustra trecho do primeiro exame de avaliação.

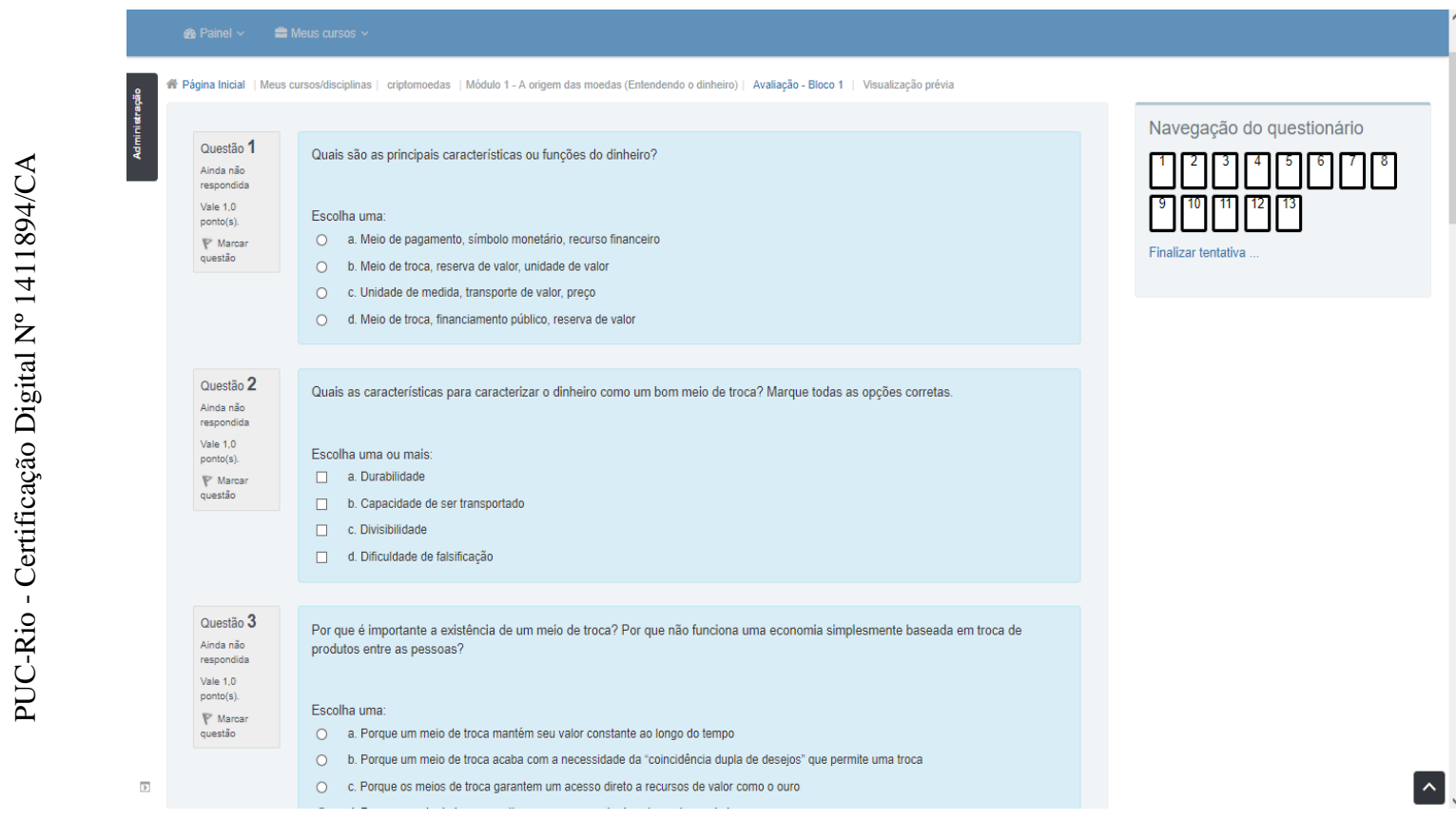

Figura 22 - Impressão de tela com trecho do exame de avaliação do módulo 1 do curso

O sistema foi configurado para permitir múltiplas tentativas de realização do exame. Portanto, cada vez que o aluno finalizava o exame ele recebia instantaneamente a sua nota e a correção. Se ele não fosse aprovado (nota mínima de 6,0), poderia tentar novamente o questionário. $O$ sistema rodava automaticamente um procedimento de mudança na ordem das questões e das alternativas de resposta, de forma que o aluno precisava entender a resposta do gabarito para realizar o acerto na segunda tentativa. 


\section{4 Coleta de Dados, Harmonização e Seleção das Variáveis}

Tratando agora da coleta de dados para pesquisa, toda ela foi realizada no ambiente online, a partir de duas fontes primárias. A primeira é o sistema de matrículas da CCE, que coletou os dados de identificação dos participantes, como idade, sexo, curso de formação, dentre outros. A segunda fonte e principal, foi a plataforma Moodle, que coletou todos os dados de atividade dos participantes ao longo do curso. Todos os dados registrados foram armazenados nos servidores do RDC e foram acessados via aplicativos de consulta à base de dados.

A partir dos dados coletados no servidor do RDC, foi criada uma base de dados filtrada para posterior análise. Estes dados nada mais são do que a resposta quantificada para cada uma das variáveis selecionadas. Antes do início da análise, foi feito um trabalho de harmonização dos dados para verificar qualquer inconsistência na base (ex.: espaços em branco, caracteres não identificados, etc.) e para ajustar erros semânticos, tendo em vista que alguns campos de identificação eram de texto livre para o participante. Por exemplo, o campo de instituição de ensino (ex.: alguns alunos escreveram USP, outros Universidade de São Paulo, outros FEA-USP, etc.). Também foi feita uma transformação de dados de algumas variáveis categóricas binárias que estavam no formato texto para o formato numérico (dummy). Um exemplo desta transformação foi no campo referente ao preenchimento ou não, por parte do aluno, do formulário de avaliação do curso. Os valores importados eram "Não" e "Sim", tendo sido estes transformados para 0 e 1. Por último, foi feita uma transformação do campo de nome, que a partir de uma função de concatenação de dados, gerou um código único de identificação para cada participante. O objetivo desta transformação era o de manter o anonimato dos participantes na pesquisa.

Ao final a base contabilizou 49.770 registros, distribuídos em 1.185 linhas e 42 colunas de dados coletados no MOOC de Introdução às Criptomoedas. A figura ilustra um pequeno trecho da base. 


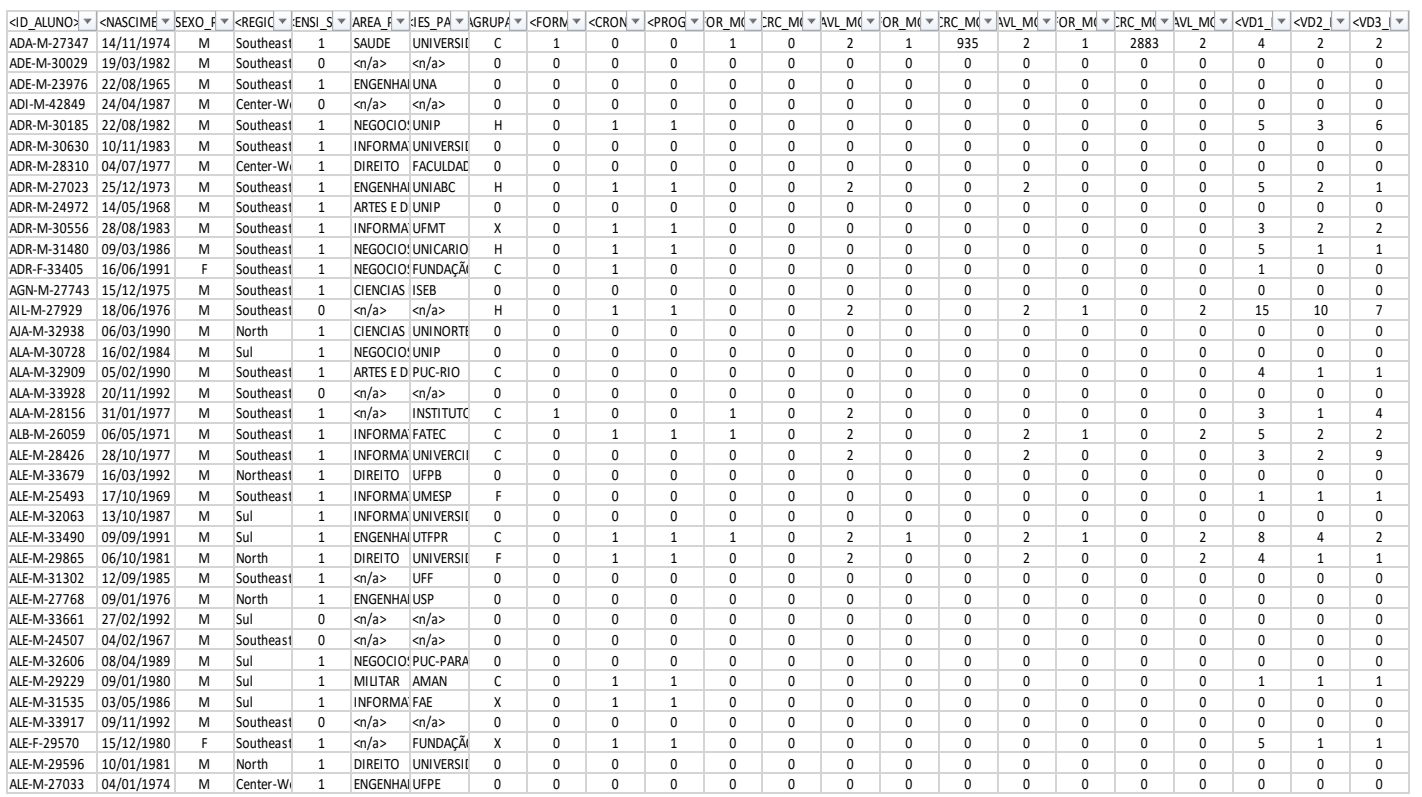

Figura 23 - Impressão de Tela referente a um extrato da base de dados do MOOC de Introdução às Criptomoedas

De forma resumida, apresentamos o processo de coleta de dados na figura a seguir, que inclui as suas três etapas chave.

Definição das Variáveis de Análise, a partir das dimensões teóricas exploradas na revisão bibliográfica

Coleta dos Dados na Página de Inscrição do Curso a partir do seu lançamento e durante o período do curso no Ambiente Virtual de Aprendizagem (Moodle)
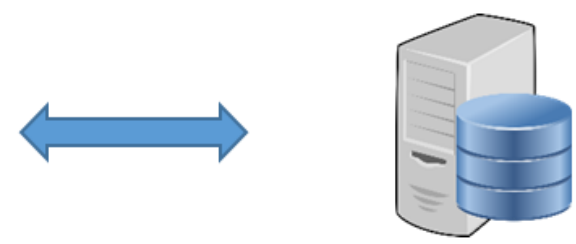

Importação e transformação dos dados coletados nos servidores do RDC em uma base de dados de trabalho e com os dados harmonizados

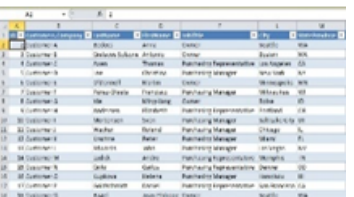

Figura 24 - Processo de Coleta de Dados 
Passamos agora para a descrição das variáveis selecionadas para integrar a base de pesquisa, iniciando pelas variáveis demográficas. Os dados para formação destas variáveis, todas elas independentes, foram coletadas no formulário de matricula do aluno no curso, através da página de inscrição no site da CCE/PucRio. Algumas delas foram geradas diretamente a partir do dado original coletado, outras foram resultado de transformação de dados e algumas outras acabaram não sendo utilizadas na pesquisa devido a qualidade dos dados gerados. O detalhamento destas modificações será descrito na seção seguinte, que fala sobre o processo de filtragem e harmonização dos dados. O quadro a seguir lista estas variáveis.

\begin{tabular}{|c|l|l|l|}
\hline Código da Variável & Descrição da Variável & Tipo de Dado & Valores \\
\hline <ID_ALUNO> & Código de indetificação do participante & Alfanumeric & Dado concatenado para manter anonimato \\
\hline <NASCIMEN> & Idade do participante & Numeric & Data de Nascimento \\
\hline <SEXO_PAR> & Sexo do participante & Text & M = Masculino; F = Feminino \\
\hline <REGION> & Localização do participante & Text & Sul, Sudeste, Leste, Oeste, Norte, Nordeste \\
\hline <ENSI_SUP> & Ensino Superior & Numeric & 0 = Não; $1=$ Sim \\
\hline <AREA_PAR> & Área de Estudo & Text & Nome da Área \\
\hline <IES_PART> & Instituição de Ensino & Text & Nome da IE \\
\hline
\end{tabular}

Quadro 11 - Lista de Variáveis Demográficas selecionadas para pesquisa

Passamos agora a descrever esta importante variável responsável pelo agrupamento dos alunos com vias de formar um grupo experimental e um grupo de controle. Esta variável, classificada como independente e categórica, foi chamada de Grupo de Controle e codificada como <AGRUPAME>.

\begin{tabular}{|c|l|l|l|}
\hline Código da Variável & Descrição da Variável & Tipo de Dado & Valores \\
\hline <AGRUPAME $>$ & Grupo de Controle & Numeric & $\mathrm{H}, \mathrm{C}, \mathrm{F}$ ou $\mathrm{X}\left({ }^{*}\right)$ \\
\hline
\end{tabular}

Quadro 12 - Variável de Agrupamento

(*) $H=$ Mediador, $C=$ Controle, $F=$ Fora da Pesquisa, $X=$ Não preenchido

Conforme descrito anteriormente, no primeiro acesso ao ambiente do curso, os participantes deveriam responder ao termo de consentimento de pesquisa online. Haviam duas opções de escolha (participar ou não participar da pesquisa) e qualquer uma das escolhas que o participante fizesse, ele teria acesso completo ao ambiente do curso. Enquanto ele não fizesse uma escolha, o acesso ao ambiente do curso ficava restrito à esta tela. 
Os participantes que fizeram uma escolha, foram alocados em três diferentes grupos. O primeiro grupo, identificado como "F", contém os participantes que optaram por não compartilhar seus dados para fins de pesquisa. Portanto, qualquer dado gerado no ambiente do curso a partir das atividades dos participantes deste grupo, foi descartado da pesquisa.

O segundo e terceiro grupo, identificados como "H" e "C", contém os participantes que optaram por compartilhar seus dados para fins de pesquisa. A separação entre estes dois grupos foi feita automaticamente pelo sistema de maneira randômica, ou seja, uma escolha aleatória. Os dois grupos tiveram acesso ao mesmo conteúdo do curso, porém um grupo não tinha acesso a atividade do outro. A diferença entre os dois grupos é que nos fóruns de discussão do grupo "H" estava presente o mediador, que é o nosso constructo de pesquisa, conforme descrito no capítulo anterior. Nos fóruns do grupo "C" não estava presente o mediador ou qualquer outro tipo de interferência externa. Somente estavam presentes os participantes alocados no grupo "C", que para fins da pesquisa se estabelece como o grupo de controle. A partir da análise da diferença entre os resultados nas variáveis de comportamento, tentamos medir os efeitos da inserção de um mediador na participação dos alunos no curso online e os efeitos sobre os resultados das avaliações.

Por último, os participantes do curso que não fizeram nenhuma escolha não tiveram o acesso concedido ao ambiente do curso e na variável agrupamento receberam o valor " $X$ ". Evidentemente este grupo não gerou nenhum tipo de registro de atividade no curso, com exceção dos dados demográficos coletados no momento da matrícula e que serão utilizados somente para fins de estatística descritiva no nível curso. Felizmente a maior parte dos participantes foi alocado nos grupos "H" e "C", viabilizando uma base útil e relevante para análise dos dados. No capítulo de análise dos resultados apresentamos uma tabela contabilizando o número de participantes em cada grupo. As variáveis associadas às atividades do participante no curso expressam, de forma resumida, o engajamento e o desempenho dos alunos no curso. Além de possibilitar a análise descritiva do comportamento dos participantes no MOOC, elas também nos permitiram medir as diferenças entre os participantes dos grupos " $\mathrm{C}$ " e "H". A partir disso avaliamos os efeitos da inserção do mediador nas atividades deste 
grupo de alunos no curso, por exemplo, nos fóruns de discussão do curso e nos resultados dos exames de avaliação do curso.

A seguir, passamos a descrever as variáveis associadas a estas atividades do curso. O quadro a seguir apresenta uma lista destas variáveis incluindo o código utilizado, a sua descrição, tipo de dado e os possíveis valores de atribuição.

\begin{tabular}{|c|c|c|c|}
\hline Código da Variável & Descrição da Variável & Tipo de Dado & Valores \\
\hline$\langle$ FORM_AVA $>$ & Formulário de avaliação do curso & Numeric & 0 = não preenchido; 1 = preenchido \\
\hline 〈CRONOGRA〉 & Visualização do cronograma do curso & Numeric & 0 = não visualizado; $1=$ visualizado \\
\hline 〈PROGRAMA> & Visualização do programa do curso & Numeric & 0 = não visualizado; 1 = visualizado \\
\hline$\langle$ FOR_MOD1> & Participação no fórum de discussão do módulo 1 & Numeric & 0 = não participou; \# = quantidade de postagens \\
\hline 〈CRC_MOD1> & Quantidade de caracteres postados no fórum & Numeric & \# = quantidade total de caracteres no fórum \\
\hline$\langle$ AVL_MOD1> & Exame de avaliação do Módulo 1 & Numeric & 0 = não concluído; 1 = concluído; 2 = concluído e aprovado \\
\hline$\langle$ FOR_MOD2> & Participação no fórum de discussão do módulo 2 & Numeric & 0 = não participou; \# = quantidade de postagens \\
\hline$\langle$ CRC_MOD2> & Quantidade de caracteres postados no fórum & Numeric & \# = quantidade total de caracteres no fórum \\
\hline$\langle$ AVL_MOD2> & Exame de avaliação do Módulo 2 & Numeric & 0 = não concluido; 1 = concluído; 2 = concluído e aprovado \\
\hline$\left\langle F O R \_M O D 3\right\rangle$ & Participação no fórum de discussão do módulo 3 & Numeric & 0 = não participou; \# = quantidade de postagens \\
\hline 〈CRC_MOD3> & Quantidade de caracteres postados no fórum & Numeric & \# = quantidade total de caracteres no fórum \\
\hline <AVL_MOD3> & Exame de avaliação do Módulo 3 & Numeric & 0 = não concluído; 1 = concluído; 2 = concluído e aprovado \\
\hline$\langle$ VD1_MOD1〉 & Visualização da Aula 1 do Módulo 1 & Numeric & 0 = não visualizado; $\#$ = quantidade de visualizações \\
\hline$\langle\mathrm{VD2}$ MOD1 $\rangle$ & Visualização da Aula 2 do Módulo 1 & Numeric & 0 = não visualizado; $\#=$ quantidade de visualizaçôes \\
\hline$\langle$ VD3_MOD1> & Visualização da Aula 3 do Módulo 1 & Numeric & 0 = não visualizado; \# = quantidade de visualizaçôes \\
\hline$\langle$ VD4_MOD1> & Visualização da Aula 4 do Módulo 1 & Numeric & 0 = não visualizado; $\#=$ quantidade de visualizaçôes \\
\hline$\langle$ VD5_MOD1> & Visualização da Aula 5 do Módulo 1 & Numeric & 0 = não visualizado; $\#$ = quantidade de visualizações \\
\hline$\langle$ VD6_MOD1> & Visualização da Aula 6 do Módulo 1 & Numeric & 0 = não visualizado; $\#=$ quantidade de visualizações \\
\hline$\langle$ VD7_MOD1> & Visualização da Aula 7 do Módulo 1 & Numeric & 0 = não visualizado; $\#=$ quantidade de visualizações \\
\hline$\langle$ VD8_MOD1> & Visualização da Aula 8 do Módulo 1 & Numeric & 0 = não visualizado; $\#=$ quantidade de visualizaçôes \\
\hline$\langle$ VD9_MOD1> & Visualização da Aula 9 do Módulo 1 & Numeric & 0 = não visualizado; $\#=$ quantidade de visualizaçôes \\
\hline$\left\langle V D 1 \_M O D 2\right\rangle$ & Visualização da Aula 1 do Módulo 2 & Numeric & 0 = não visualizado; $\#=$ quantidade de visualizaçôes \\
\hline$\langle$ VD2_MOD2> & Visualização da Aula 2 do Módulo 2 & Numeric & 0 = não visualizado; \# = quantidade de visualizações \\
\hline$\langle$ VD3_MOD2> & Visualização da Aula 3 do Módulo 2 & Numeric & 0 = não visualizado; $\#=$ quantidade de visualizações \\
\hline$\langle$ VD4_MOD2> & Visualização da Aula 4 do Módulo 2 & Numeric & 0 = não visualizado; $\#$ = quantidade de visualizações \\
\hline$\langle$ VD5_MOD2> & Visualização da Aula 5 do Módulo 2 & Numeric & 0 = não visualizado; $\#=$ quantidade de visualizaçôes \\
\hline$\langle$ VD6_MOD2> & Visualização da Aula 6 do Módulo 2 & Numeric & 0 = não visualizado; \# = quantidade de visualizações \\
\hline$\left\langle V D 1 \_M O D 3\right\rangle$ & Visualização da Aula 1 do Módulo 3 & Numeric & 0 = não visualizado; $\#$ = quantidade de visualizações \\
\hline$\langle V D 2$ MOD3> & Visualização da Aula 2 do Módulo 3 & Numeric & 0 = não visualizado; $\#=$ quantidade de visualizações \\
\hline$\langle$ VD3_MOD3> & Visualização da Aula 3 do Módulo 3 & Numeric & 0 = não visualizado; $\#=$ quantidade de visualizações \\
\hline$\langle$ VD4_MOD3> & Visualização da Aula 4 do Módulo 3 & Numeric & 0 = não visualizado; \# = quantidade de visualizaçốes \\
\hline$\langle$ VD5_MOD3> & Visualização da Aula 5 do Módulo 3 & Numeric & 0 = não visualizado; \# = quantidade de visualizaçôes \\
\hline$\langle$ VD6_MOD3> & Visualização da Aula 6 do Módulo 3 & Numeric & 0 = não visualizado; \# = quantidade de visualizações \\
\hline 〈VD7_MOD3> & Visualização da Aula 7 do Módulo 3 & Numeric & 0 = não visualizado; $\#=$ quantidade de visualizações \\
\hline 〈ACTIVITY> & Define se o participante realizou alguma atividade & Numeric & $0=$ nenhuma atividade no curso; 1 = pelo menos uma atividade \\
\hline
\end{tabular}

Quadro 13 - Lista de Variáveis associadas a atividades do participante no curso

As três primeiras variáveis são relativas ao trecho introdutório do curso e o fato do aluno ter visualizado esta parte, demonstra que ele fez uma preparação mínima para entender o funcionamento do curso. Representado por estas variáveis, estão as atividades de estudo do cronograma do curso, visualização do vídeo do professor explicando a mecânica de funcionamento do curso, o estudo do 
programa do curso. Também incluímos uma avaliação final da qualidade do curso (não é um exame) e os alunos que preencheram demonstram uma maior atenção com o planejamento do curso.

As nove variáveis seguintes são, na verdade, três variáveis que se repetem para cada um dos três módulos do curso. Duas delas podem ser resumidas a participação do aluno no fórum de cada um dos módulos (tanto em termos de número de postagens quanto de tamanho das postagens). A terceira reflete o desempenho do participante no exame de avaliação do módulo.

O bloco final com 22 variáveis está associado ao material didático do curso, mais uma vez dividido em três módulos. Cada uma das variáveis é uma aula no curso e os valores possíveis de resposta são o número de vezes que o participante visualizou a aula. Todas as aulas foram feitas no formato de vídeo, com cerca de 10 minutos de duração, conforme descrito na seção anterior. As aulas do módulo foram agrupadas com um recurso chamado pela plataforma como um livro. A imagem abaixo demonstra a estrutura do livro com as 9 aulas do módulo 1.

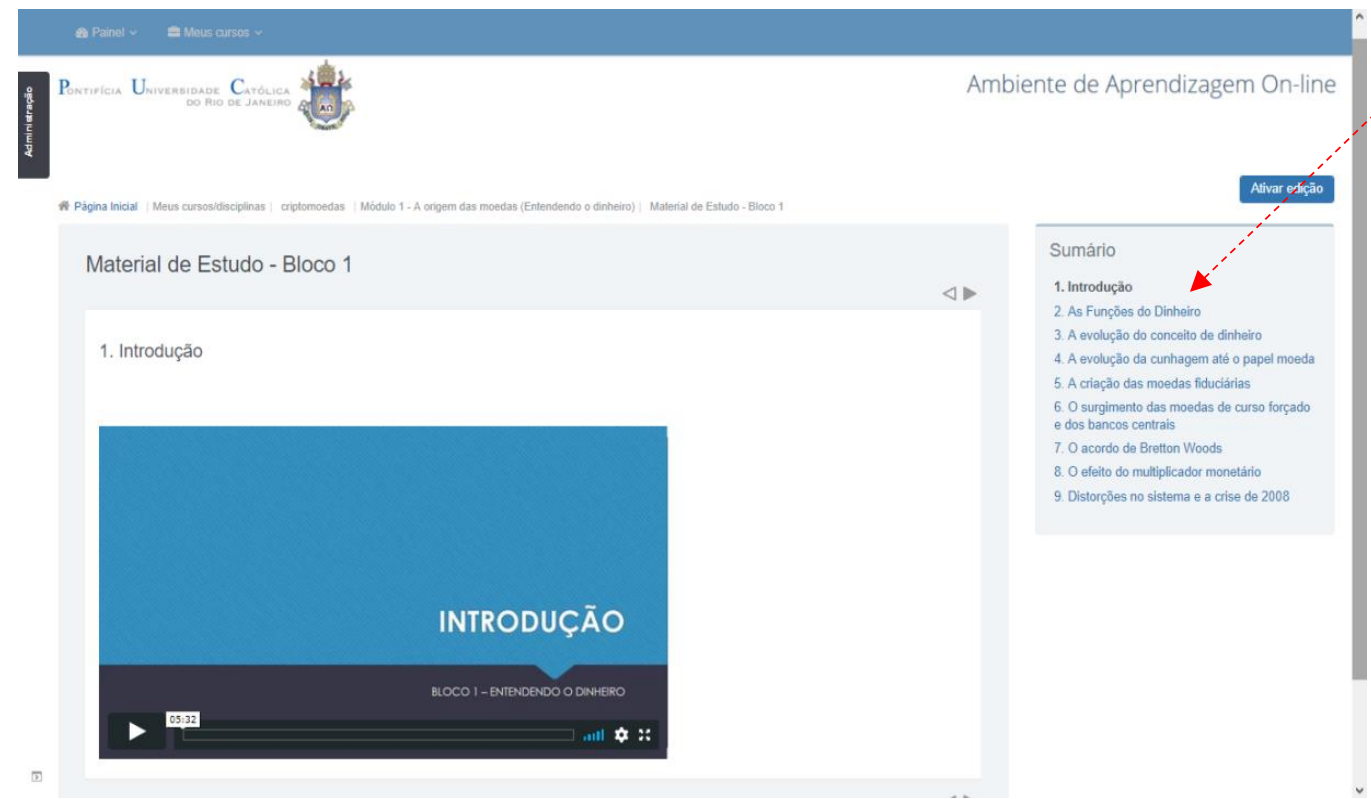

Figura 25 - Primeira página do Livro com o material de estudos do Módulo 1 do curso

Passamos agora para a descrição do procedimento de tratamento dos dados, com o objetivo de verificar a adequação aos procedimentos de análise estatística que serão aplicados e a descrição dos métodos de análise utilizados. 


\section{5 Tratamento dos Dados}

Conforme mencionado anteriormente, após o trabalho de harmonização dos dados, a base contabilizava 49.770 registros, distribuídos em 1.185 linhas de observações (alunos) e 42 colunas de variáveis. Entretanto, muitos destes campos estavam incompletos com registros de dados não disponíveis (n/a). Além disso, também incluíam diversos registros de alunos que não acessaram o curso depois de terem se matricula - ou seja, não geraram nenhum dado de atividade no curso. Para estes alunos só haviam os dados demográficos, que não tem relevância neste estudo, pois não podem ser cruzados com os dados de atividade e desempenho no curso. A seguir descrevemos o procedimento de filtragem e redução da base.

\subsection{1}

\section{Filtragem da Base}

O primeiro passo foi a remoção dos registros dos participantes que não acessaram o ambiente do curso e, portanto, não geraram nenhum registro de atividade. No total, foram contabilizados 537 destes casos, ou seja, pessoas que somente fizeram a matrícula no curso, mas nunca acessaram a plataforma, ou acessaram a plataforma do curso, mas não responderam ao termo de consentimento de pesquisa, que era mandatório para acessar o ambiente com as atividades do curso. Sendo assim, a base passou a contar com 648 registros.

Em seguida foi feita a extração dos casos de participantes que optaram por responder ao termo de consentimento com uma negativa de autorização do uso de seus dados na pesquisa. Estes participantes tiveram total acesso ao curso e ao material didático, mesmo não tendo consentido em compartilhar seus dados de atividades. No total foram contabilizados 83 destes casos, que também foram excluídos da base de pesquisa. Sendo assim, a base passou a contar com 565 observações válidas para pesquisa.

O último passo na filtragem foi feito na análise da qualidade dos registros gerados para as variáveis. De forma geral, o trabalho prévio de harmonização dos dados já havia eliminado o risco de informações iguais estarem registradas em formatos diferentes. Por exemplo, uma pessoa escreveu o nome da cidade de São 
Paulo com acento e outra escreveu sem acento. Isso seria interpretado como dois valores diferentes pelos softwares de análise dos dados. Entretanto, apesar do trabalho de harmonização, ainda percebemos a presença de alguns dados que poderiam confundir a análise.

Uma primeira substituição que fizemos foi dos campos cidade e estado por um campo de região. A quantidade de municípios no Brasil é muito grande e os gráficos de análise estavam ficando muito grandes, dificultando a visualização da distribuição geográfica dos participantes. Com a mudança para região, a visualização foi reduzida para cinco possíveis valores de dados (Sul, Sudeste, Norte, Nordeste, Sul e Centro-Oeste).

Uma segunda modificação foi feita no campo de formação do participante. Este seria um dado bastante útil para a análise, pois se refere ao perfil de formação (Engenharia, Administração, Medicina, etc.). Entretanto, cerca de $30 \%$ dos participantes não preencheram este campo na matrícula no curso. Sendo assim, decidimos descartar esta variável na pesquisa. O mesmo foi feito em relação a identificação da instituição de ensino do participante, que também tinha uma quantidade muito grande de campos não preenchidos. Esta variável também foi descartada.

Uma terceira modificação foi no campo de data de nascimento, sendo este substituído por um campo de idade. Esta informação é mais interessante para análise posterior. Por último, para fechar as modificações na base de pesquisa, foi criado um registro novo, contendo a informação de presença ou não de atividade do aluno no curso - no que tange o acesso ao material didático. Este registro, com valores numéricos e binários (0 ou 1), deu origem a uma nova variável utilizada para mapear os alunos se matricularam, acessaram a plataforma, foram alocados em um grupo, visualizaram o ambiente, mas não acessaram nenhum dos Recursos Educacionais Didáticos do curso. Fazendo uma analogia, são os alunos que foram à aula, mas "ficaram dormindo" o curso todo.

Concluído o processo de filtragem e modificações, a base final ficou composta de 565 casos observados (alunos do curso), com 22.560 registros, distribuídos em 40 variáveis para análise. A seguir traçamos um perfil da base de pesquisa, que naturalmente reflete o perfil dos alunos do curso. 


\section{5 .2 Metodologia de Análise}

O objetivo desta pesquisa é realizar um estudo de campo para compreender o funcionamento de um MOOC direcionado para o público brasileiro, atribuindo um olhar especial para a questão da comunicação no ambiente de aprendizagem. De forma mais específica, queremos medir os efeitos da mediação na participação e desempenho dos estudantes em cursos MOOC. Quais os efeitos deste mediador na participação dos alunos nas atividades do curso (fóruns, vídeo aulas, material de apoio)? Quais os efeitos deste mediador no desempenho dos alunos no curso (exames)? Também queremos entender se as categorias demográficas que temos acesso (idade, sexo e região) tem algum efeito no engajamento e desempenho dos alunos no curso.

Considerando a amostra selecionada de alunos do curso MOOC de Introdução às criptomoedas $(\mathrm{N}=565)$ e o conjunto de variáveis selecionados para coleta de dados, aplicamos técnicas estatísticas para analisar estes dados e subsidiar uma discussão em relação aos resultados encontrados. Foram definidos dois tipos de variáveis, sendo o primeiro tipo as variáveis numéricas (quantidade de postagens, tamanho das postagens, visualização do material do curso) e o segundo tipo as variáveis categóricas (idade, sexo, região, agrupamento, aprovação no curso). A partir destas variáveis desenvolvemos as seguintes análises:
a) Estatísticas descritivas do curso
b) Teste de normalidade das variáveis numéricas (Testes qui-quadrado e Kolmogorov-Smirnov)
c) Análise da Influência de Grupo nas atividades do curso (ANOVA)
d) Influência de Grupo nos exames de cada módulo (Teste qui-quadrado)
e) Verificação dos Efeitos das características demográficas nas atividades do curso (ANOVA)
f) Análise da correlação entre idade e atividades do curso (Análise de Regressão Linear)




\section{6 Limitações do Método}

O método utilizado, baseado em análises quantitativas de dados, apresenta diversas limitações. Elas devem ser consideradas ao se extrair conclusões a partir dos resultados obtidos. Inferências devem ser feitas com muita parcimônia, evitando generalizações a partir dos resultados obtidos nos testes. Algumas destas limitações também abrem uma série de oportunidades para pesquisas futuras, agregando novos métodos, tanto de coleta quanto de análise dos dados. Propostas de pesquisa futura serão feitas no capítulo de conclusão.

Listamos abaixo, de forma objetiva e pontual, algumas das limitações que percebemos na pesquisa realizada:

- A qualidade da análise está intrinsicamente ligada a qualidade dos dados coletados. No caso deste curso, muitos dos instrumentos de coleta de dados estavam pré-formatados e não puderam ser alterados para fins desta pesquisa. Um bom exemplo é o sistema de matrícula do curso, cujo formulário não utiliza valores harmonizados em diversos campos. Com isso muitos dados tiveram que ser descartados, reduzindo o escopo de análise de dados. Como exemplo, não pudemos utilizar os dados de instituição de ensino e nem o curso de formação dos participantes.

- A amostra selecionada para pesquisa, que corresponde aos participantes selecionados no curso (pesquisa de campo), não é probabilística. Considerando que os participantes foram originados a partir de uma divulgação dos próprios professores do curso em suas mídias sociais e em grupos de interesse, é bastante provável que a o perfil de formação da amostra de participantes do curso tenha sido influenciada pela própria rede de divulgação do curso.

- Existem diversas variáveis não observadas que podem ter efeitos no perfil de atividade, participação e desempenho dos alunos em cursos online. Uma simples mudança no tema do curso, por exemplo, pode alterar radicalmente os resultados obtidos. No momento, o tema de Moedas Digitais está com alta visibilidade despertando grande 
interesse nas pessoas. Talvez, o mesmo formato de curso, só que em outro tema, poderia alterar completamente os resultados.

- A mesma limitação citada no ponto anterior também vale para a escolha das ferramentas tecnológicas. Este curso foi baseado na plataforma aberta Moodle que, assim como toda ferramenta digital, apresenta vantagens e desvantagens. Por exemplo, o recurso utilizado pelo Moodle para gerenciar os Fóruns de discussão no curso, carece de funções de redes sociais como o recurso de marcação $\left(\operatorname{tag}^{23}\right)$. Este simples recurso pode aumentar drasticamente o engajamento de pessoas em fóruns de discussão. Portanto, o componente ferramental pode afetar significativamente a variância. Isso se estende de maneira análoga a própria opção pedagógica feita no curso. $\mathrm{O}$ formato de videoaula, também tem suas limitações e influencia diretamente nos resultados.

- A inserção de um Grupo de Controle só feita para as atividades de fórum, portanto, os efeitos da mediação só foram medidos a partir desta atividade pedagógica. Outras atividades mediadas do curso não foram sujeitas ao grupo de controle. Por exemplo, nas trocas privadas de mensagens, nas interações a partir das transmissões ao vivo no Facebook, dentre outros.

\footnotetext{
${ }^{23} \mathrm{O}$ recurso de marcação, chamado de inglês de tag, é um recurso muito utilizado em ferramentas de comentários de redes sociais como o Facebook ou Twitter. Inserindo um caractere “@” em frente do nome de outro participante da conversa, o usuário realiza a marcação deste participante. Normalmente esta função dispara um e-mail para a caixa da pessoa marcada, avisando que alguém a mencionou no debate. Ela também aciona notificações, que muitas vezes vão direto para a tela do telefone do usuário marcado. Este recurso aumenta drasticamente a chance do usuário marcado retornar ao fórum de discussão e prosseguir com novos comentários.
} 


\section{6 \\ Análise dos Resultados}

Neste capítulo vamos analisar os resultados baseados nos testes estatísticos realizados a partir dos dados gerados na pesquisa de campo, realizada no ambiente virtual de aprendizagem do MOOC de Introdução às Criptomoedas da PUC-Rio realizado nos meses de novembro e dezembro de 2017.

\section{1 \\ Estatísticas descritivas do curso}

As estatísticas descritivas do curso foram geradas a partir da amostra selecionada com $\mathrm{N}=565$. Elas são visualizadas a partir de gráficos e tabelas, seguidas de uma breve explicação. Inicialmente fazemos uma descrição das variáveis categóricas, na sua maioria com gráficos de frequência

\subsection{1 \\ Variáveis categóricas}

A primeira variável a ser descrita refere-se a região geográfica onde o participante estava localizado. A figura a seguir mostra que a grande maioria dos participantes vem da região sudeste, mais precisamente dos estados do Rio de Janeiro e São Paulo. Esta estatística está relacionada diretamente aos locais onde o curso foi anunciado. Primeiramente no grupo de moedas digitais ${ }^{24}$ do Facebook, que resultou no maior fluxo de inscrições do curso. Analisando a página de moedas digitais, percebemos que $61 \%$ dos membros vem da região sudeste, o que se aproxima da distribuição do curso com $64 \%$ dos participantes vindo da região sudeste. O mesmo aconteceu com a distribuição de sexo, que no caso do grupo são $81 \%$ de homes e $19 \%$ de mulheres. No curso, como se pode notar na figura a seguir, a distribuição ficou ainda mais enviesada para o público masculino,

${ }^{24}$ O Grupo de Moedas Digitais é um grupo de estudos no Facebook, que na data de 22/01/2018 contava com 2.042 membros. Este grupo foi uma das principais fontes de divulgação do curso na época das matrículas. Membros deste grupo compartilharam o link de divulgação do curso em outros grupos, criando propagação rápida da mensagem fazendo com que em três dias após a divulgação inicial as inscrições do curso já estavam esgotadas. Portanto, espera-se que o perfil dos membros seja, de alguma forma, similar ao perfil dos membros do grupo. 
totalizando um percentual de $88,3 \%$ para homens e $11,7 \%$ para mulheres. Esta informação deve ser levada em consideração na generalização dos resultados deste curso, tendo em vista que a distribuição de sexo apresentada no curso não é representativa da distribuição de sexo na educação online de maneira mais ampla. Segundo o censo da ABED (CENSO ABED, 2016) as mulheres são a maioria na educação online, com uma parcela de cerca de $56 \%$ do total de participantes. Portanto, a amostra analisada se difere do perfil da maioria dos cursos online brasileiros e acreditamos que este perfil mais masculino possa ser atribuído ao tema de criptomoedas. Chegamos nesta conclusão porque, segundo experiência do autor da tese durante o ano de 2017, ministrando dez turmas presenciais no curso de criptomoedas que totalizaram 350 alunos, a distribuição foi muito parecida os resultados do curso online.

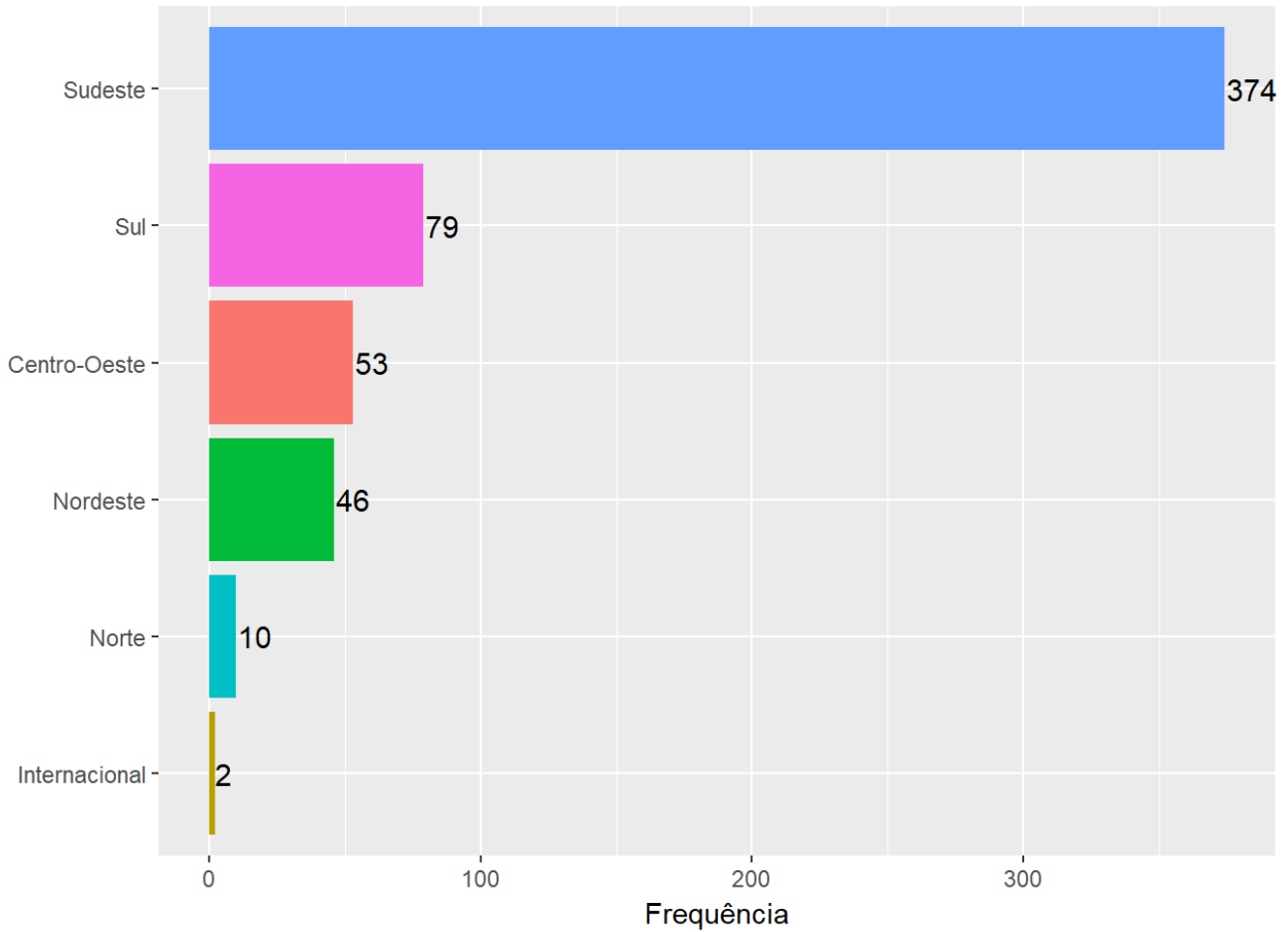

Figura 26 - Gráfico de Barras com a distribuição dos participantes do curso por região geográfica 


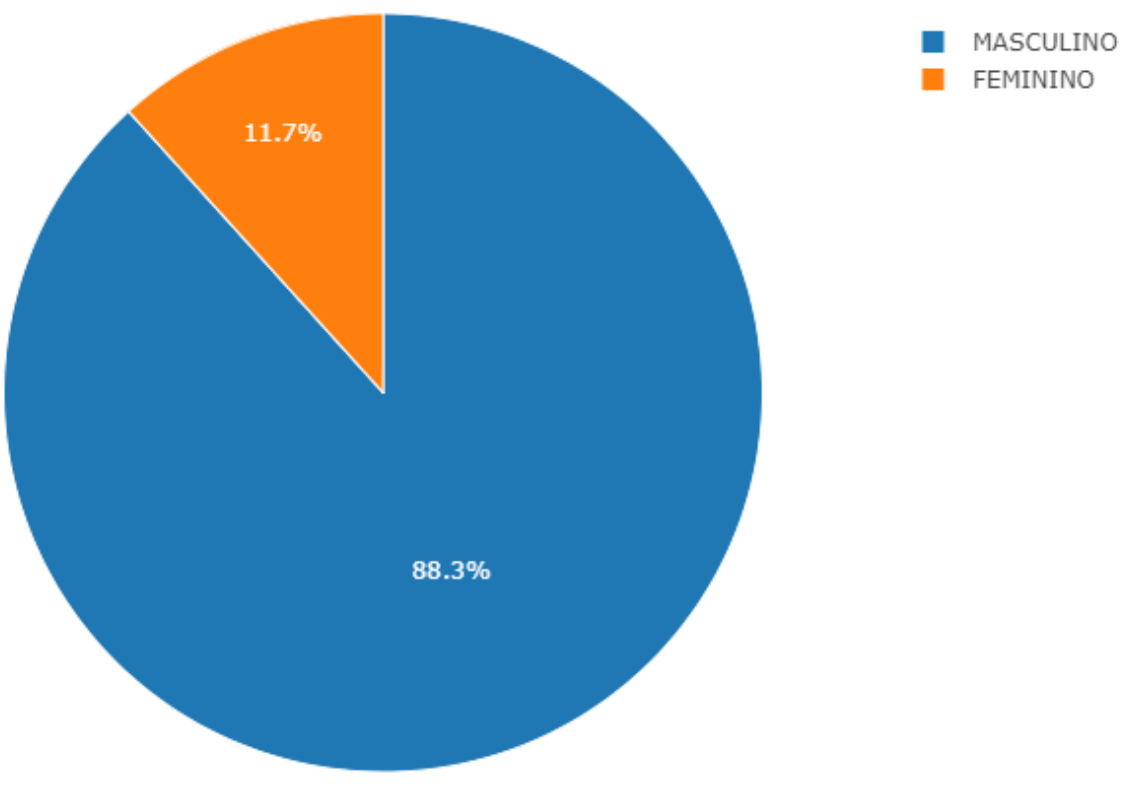

Figura 27 - Distribuição dos participantes do curso por sexo

Passamos agora para uma descrição das visualizações de duas atividades básicas no curso, que integram o material de preparação. O cronograma e o programa do curso foram disponibilizados logo no início do conteúdo e eram uma peça chave para o aluno concluir com sucesso o curso. Eles foram representados pelas variáveis <PROGAMA $>$ e $\langle$ CONOGRA $\rangle$, tendo possibilidade de valor como "Sim" (visualizado ao menos uma vez) ou "Não" (nunca visualizado). As figuras abaixo mostram os resultados de visualização.
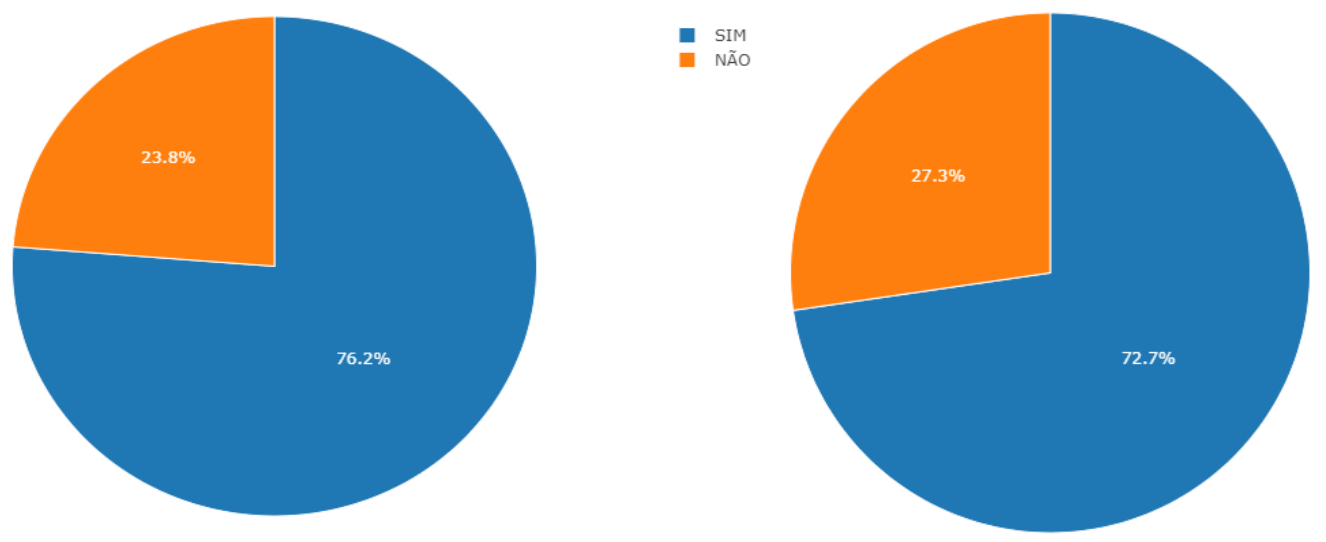
o Cronograma do Curso

Figura 29 - Percentual dos alunos que visualizaram o programa do curso 
Como se pode notar nas figuras acima, cerca de três quartos dos alunos do curso visualizaram o material de preparação. Apesar de ser a maioria, nos perguntamos como um aluno participa de um curso sem ler o material de preparação. Mais à frente na parte de estatística inferencial vamos avaliar se houve alguma correlação entre estas variáveis e o desempenho no curso.

Passamos agora a descrever o perfil de idade do curso. Analisando o histograma abaixo, é possível perceber uma maior concentração de alunos com idade próxima a 30 anos. Este percentual também se assemelha ao perfil do grupo de moedas digitais do Facebook, que originou grande parte dos alunos. Neste grupo, o percentual de participantes entre 24-34 anos é de 39\%. Entretanto, em relação ao perfil de idade do aluno online, o perfil de alunos do curso ficou um pouco abaixo. O censo ABED (CENSO ABED, 2016) aponta que 37\% dos alunos online estão em uma faixa de 31-40 anos, ou seja, um pouco acima. Acreditamos que esta diferença também se deva ao tópico do curso, que tem atraído uma geração mais nova, tradicionalmente menos conservadora em relação a aspectos de inovação na área financeira.

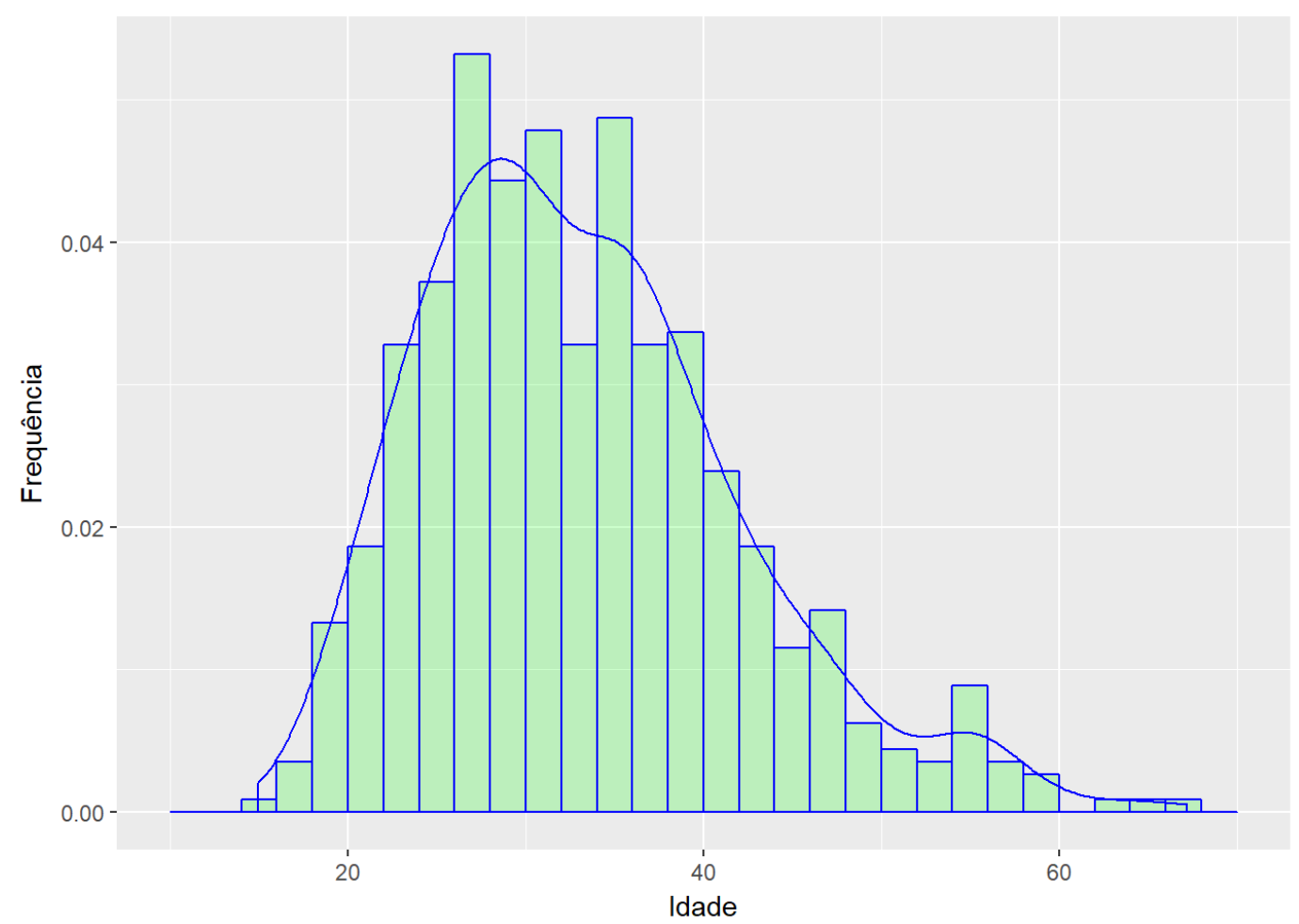

Figura 30 - Histograma de distribuição de idade dos participantes no curso 
Com relação ao agrupamento dos alunos, houve uma maior concentração no grupo de Controle. Reforçamos que esta seleção de grupo foi feita automaticamente pelo sistema. As figuras abaixo demonstram a separação, ficando o grupo Hipótese com 260 integrantes $(46,1 \%)$ e o grupo de controle com 305 integrantes $(53,9 \%)$.

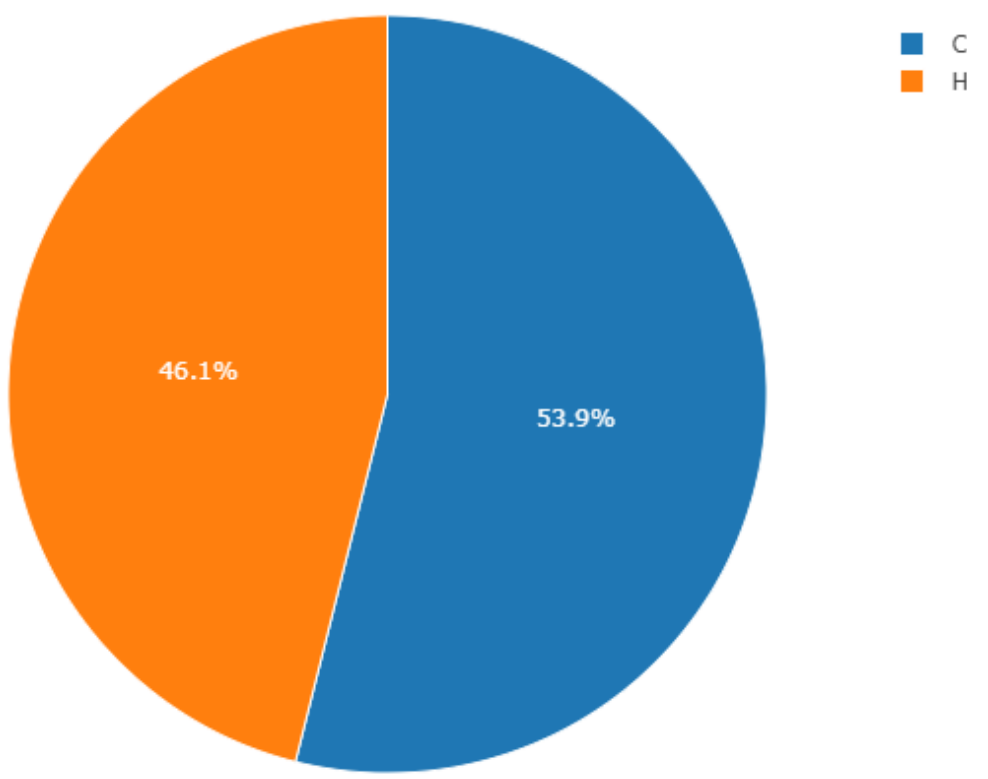

Figura 31 - Distribuição percentual dos participantes do curso por agrupamento (C-Controle, $\mathrm{H}$-Mediador $)$

Também foi feita uma verificação da distribuição de idade, que é uma variável importante de análise. Teoricamente o processo automático de seleção de grupos deveria distribuir aleatoriamente os integrantes, sendo assim a média de idade deveria ser parecida. O gráfico de Boxplot ilustrado na figura a seguir demonstra que a distribuição de idades entre os grupos foi bastante próxima, não causando assim qualquer distorção na análise em relação a esta variável específica. 


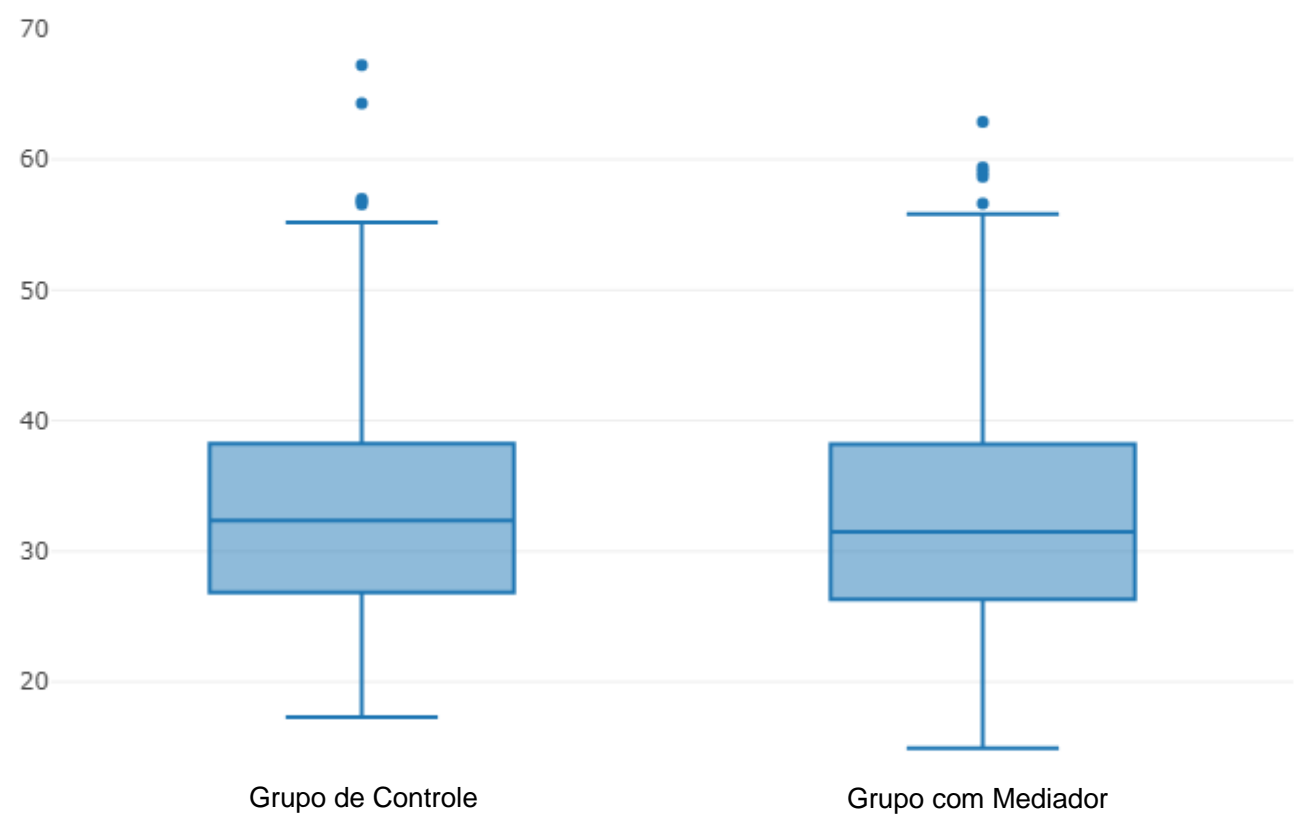

Figura 32 - Boxplot da distribuição dos agrupamentos por frequência de idade

\section{1 .2 \\ Variáveis numéricas}

Passamos agora para a descrição das variáveis numéricas através de tabelas com as estatísticas de Média, Mediana e Desvio Padrão. A primeira delas descreve a participação na discussão dos módulos 1, 2 e 3. Esta participação está medida em número de postagens entre os 565 participantes do curso e apontou para uma média de 0,37 postagens no módulo 1 , sucedida por 0,27 postagens no módulo 2 e por último 0,33 postagens no módulo 3. Isso demonstra que muitos participantes não postaram nada, pois as médias ficaram abaixo de 1 e a mediana ficou zerada, ou seja, a maior frequência foi dos participantes que não fizeram nenhuma postagem. Somados todos os fóruns, o número médio de postagens ficou próximo a 1, o que na nossa interpretação demonstra, de forma geral, um engajamento baixo com as atividades de discussão no curso. Também é importante mencionar que nós não consideramos na análise as postagens feitas pelos alunos no fórum de apresentação do curso, onde os mesmos têm a chance de se apresentar pessoalmente para a turma. Neste fórum, o índice de participação foi alto, mas julgamos que o conteúdo não seria relevante para o curso e poderia distorcer os dados reais de participação nos tópicos efetivos do curso. 
Statistics

\begin{tabular}{|l|r|r|r|r|}
\hline & $\begin{array}{c}\text { Participation } \\
\text { on the } \\
\text { discussion } \\
\text { forum of the } \\
\text { Module } 1\end{array}$ & $\begin{array}{c}\text { Participation } \\
\text { on the } \\
\text { discussion } \\
\text { forum of the } \\
\text { Module 2 }\end{array}$ & $\begin{array}{c}\text { Participation } \\
\text { on the } \\
\text { discussion } \\
\text { forum of the } \\
\text { Module } 3\end{array}$ & $\begin{array}{c}\text { Total amount } \\
\text { of forum } \\
\text { posts }\end{array}$ \\
\hline V Malid & 565 & 565 & 565 & 565 \\
Mean & 0 & 0 & 0 & 0 \\
Median &, 37 &, 27 &, 33 &, 9628 \\
Std. Deviation &, 00 &, 00 &, 00 &, 0000 \\
Minimum &, 483 &, 443 & 0 & 1,24643 \\
Maximum & 0 & 0 & 1 &, 00 \\
\hline
\end{tabular}

Quadro 14 - Estatísticas Participação dos alunos nos fóruns de discussão

Com relação ao tamanho das postagens, medidas pelo somatório de caracteres digitados pelo participante, a média ficou em 59, 40 e 31, para os fóruns dos módulos 1, 2 e 3, respectivamente. Isso equivaleria a cerca de 10 palavras por postagem, se consideramos uma média de 4 caracteres por palavra. Entretanto, este valor está distorcido pela grande quantidade de participantes que não fizeram nenhuma postagem. Isso fica claro ao olhar o desvio padrão, que é cerca de 6 vezes o valor da média. Usando o somatório da média com o 1 desvio padrão, vamos chegar a 433,66 caracteres para o módulo 1, seguido de 217,02 caracteres para o módulo 2 e por último 246,55 caracteres para o terceiro módulo. Este valor é mais realístico em relação ao perfil das postagens que foram efetivamente feitas pelos participantes ativos do curso. $\mathrm{O}$ quadro a seguir demonstra estes valores.

Statistics

\begin{tabular}{|l|r|r|r|r|}
\hline & $\begin{array}{c}\text { Amount of } \\
\text { characters } \\
\text { posted on } \\
\text { forum of the } \\
\text { Module 1 }\end{array}$ & $\begin{array}{c}\text { Amount of } \\
\text { characters } \\
\text { posted on } \\
\text { forum of the } \\
\text { Module 2 }\end{array}$ & $\begin{array}{c}\text { Amount of } \\
\text { characters } \\
\text { posted on } \\
\text { forum of the } \\
\text { Module 3 }\end{array}$ & $\begin{array}{c}\text { Total amount } \\
\text { of characters } \\
\text { on forum }\end{array}$ \\
\hline $\mathrm{N} \quad$ Valid & 565 & 565 & 565 & 565 \\
Missing & 0 & 0 & 0 & 0 \\
Median & 59,02 & 40,03 & 31,05 & 130,1044 \\
Std. Deviation & 374,642 &, 00 &, 00 &, 0000 \\
Minimum & 0 & 216,987 & 215,500 & 498,88567 \\
Maximum & 5814 & 0 & 0 &, 00 \\
\hline
\end{tabular}

Quadro 15 - Estatísticas de tamanho das postagens nos fóruns dos módulos 1, 2 e 3 
Quanto ao número de visualizações de vídeo, as estatísticas demonstram uma média aproximada de 17, 7 e 6 visualizações respectivamente para os módulos 1, 2 e 3 . Ou seja, houve uma queda progressiva no número de visualizações conforme o cronograma do curso avançava. Cabe reforçar que o número de visualizações não necessariamente reflete o número de vezes que o aluno tocou o vídeo ("plays"). Estes vídeos estavam embutidos nas páginas do curso, sendo alimentados pela plataforma Vimeo, que é similar ao conhecido Youtube. Portanto, a contagem de visualização representa a quantidade de vezes que o participante acessou a página da videoaula. Apesar de não garantir a visualização do vídeo, assume-se que o participante acessou a página pois teve interesse em ver o vídeo. Um pouco mais adiante, vamos apresentar algumas estatísticas de "plays" para os vídeos a partir de dados gerados pelo Vimeo. Eles mostram que o número de "plays" dos vídeos é superior a quantidade de visualizações de página, portanto, inferimos que os participantes efetivamente tocaram o vídeo ao acessar a página.

Statistics

\begin{tabular}{|l|r|r|r|r|}
\hline & \multicolumn{1}{|c|}{$\begin{array}{c}\text { Video } \\
\text { visualization } \\
\text { Module 1 }\end{array}$} & $\begin{array}{c}\text { Video } \\
\text { visualization } \\
\text { Module 2 }\end{array}$ & $\begin{array}{c}\text { Video } \\
\text { visualization } \\
\text { Module 3 }\end{array}$ & $\begin{array}{c}\text { Total amount } \\
\text { of videos } \\
\text { visualized }\end{array}$ \\
\hline $\mathrm{N} \quad$ Valid & 565 & 565 & 565 & 565 \\
Mean & 0 & 0 & 0 & 0 \\
Median & 17,6637 & 6,8655 & 5,7628 & 30,2920 \\
Std. Deviation & 16,0000 & 6,0000 & 2,0000 & 29,0000 \\
Minimum & 14,30755 & 8,54730 & 7,89966 & 26,94441 \\
Maximum &, 00 &, 00 &, 00 &, 00 \\
\hline
\end{tabular}

Quadro 16 - Estatísticas de visualização de vídeos para os módulos 1, 2 e 3

No que tange os exames de avaliação do curso, pode-se notar na tabela a seguir que a média de avaliação foi caindo progressivamente conforme os módulos avançavam. No primeiro Módulo a média foi 0,59, passando para 0,50 no segundo módulo e 0,40 no terceiro módulo, sendo 0 não aprovado e 1 aprovado. Isso é compatível com a variável anterior de visualização das aulas. É natural que no início do curso a maioria dos alunos esteja mais animado e conforme o cronograma avança, os curiosos começam a reduzir suas atividades. 
Isso também abre uma oportunidade de adotar ações de contenção para estimular os curiosos a prosseguir com os próximos módulos.

Statistics

\begin{tabular}{|l|r|r|r|r|}
\hline & \multicolumn{1}{|c|}{$\begin{array}{c}\text { Exam } \\
\text { passing } \\
\text { Module 1 }\end{array}$} & \multicolumn{1}{|c|}{$\begin{array}{c}\text { Exam } \\
\text { passing } \\
\text { Module 2 }\end{array}$} & $\begin{array}{c}\text { Exam } \\
\text { passing } \\
\text { Moudle 3 }\end{array}$ & $\begin{array}{c}\text { Total amount } \\
\text { of exams } \\
\text { passed }\end{array}$ \\
\hline $\mathrm{N} \quad$ Valid & 565 & 565 & 565 & 565 \\
Mean & 0 & 0 & 0 & 0 \\
Median &, 5929 &, 5027 &, 4035 & 1,4991 \\
Std. Deviation & 1,0000 & 1,0000 &, 0000 & 1,0000 \\
Minimum &, 49173 &, 50044 &, 49104 & 1,35482 \\
Maximum &, 00 &, 00 &, 00 &, 00 \\
\hline
\end{tabular}

Quadro 17 - Estatísticas de aprovações nas avaliações dos Módulos 1, 2 e 3

\subsection{3 \\ Dados agregados de acesso às videoaulas}

As figuras abaixo foram extraídas da plataforma $\mathrm{Vimeo}^{25}$, onde foi feita a hospedagem e streaming de todas as videoaulas. A primeira figura aponta para o tempo total de transmissão dos vídeos, somados todos os alunos e todos os vídeos. Isso dá um senso de como que um MOOC, mesmo com características modestas em termos de tempo e material de estudo, tem de fato um caráter massivo. Ao todo, foram transmitidos um total aproximado de 72 dias de visualização de conteúdo. Ou seja, se alguém fosse replicar o tempo de transmissão das 22 videoaulas do curso para os alunos, precisaria gastar cerca de 2 meses e meio em frente à tela do computador, de forma ininterrupta.

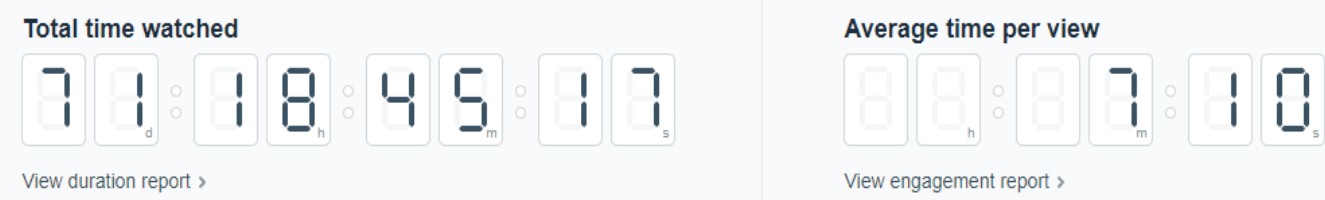

Figura 33 - Tempo total de visualização e tempo média de visualização das videoaulas do curso (Fonte: Vimeol

25 Vimeo é uma plataforma de transmissão de vídeos online, similar a conhecida plataforma Youtube e pode ser acessada através do link www.vimeo.com 
Outro interessante indicador de tempo, gerado pelo Vimeo e apresentado nesta mesma figura, refere-se ao tempo médio que os alunos gastaram em cada visualização. O resultado desta média foi 7 minutos por vídeo. Considerando a escala massiva do curso, a diversidade dos alunos e de conteúdo, este tempo de 7 minutos pode ser considerado um bom indicador para o tempo de duração ideal para uma videoaula. No MOOC, o tempo médio real de duração das videoaulas foi de 10 minutos. Para outras edições de curso, sugere-se que o valor alvo de duração das videoaulas seja inferior, mais próximo a 7 minutos.

$\mathrm{Na}$ figura a seguir pode-se ter uma visualização um pouco diferente da mesma informação de visualização de vídeos, não mais por tempo, mas sim por data. O eixo vertical representa "número de visualizações da videoaula" e o eixo horizontal a "data de visualização". A linha azul representa a quantidade de vezes que o vídeo foi tocado ("plays") e a linha azul representa a quantidade de vezes que o vídeo tocado foi finalizado, ou seja, o aluno assistiu todo o conteúdo do vídeo.

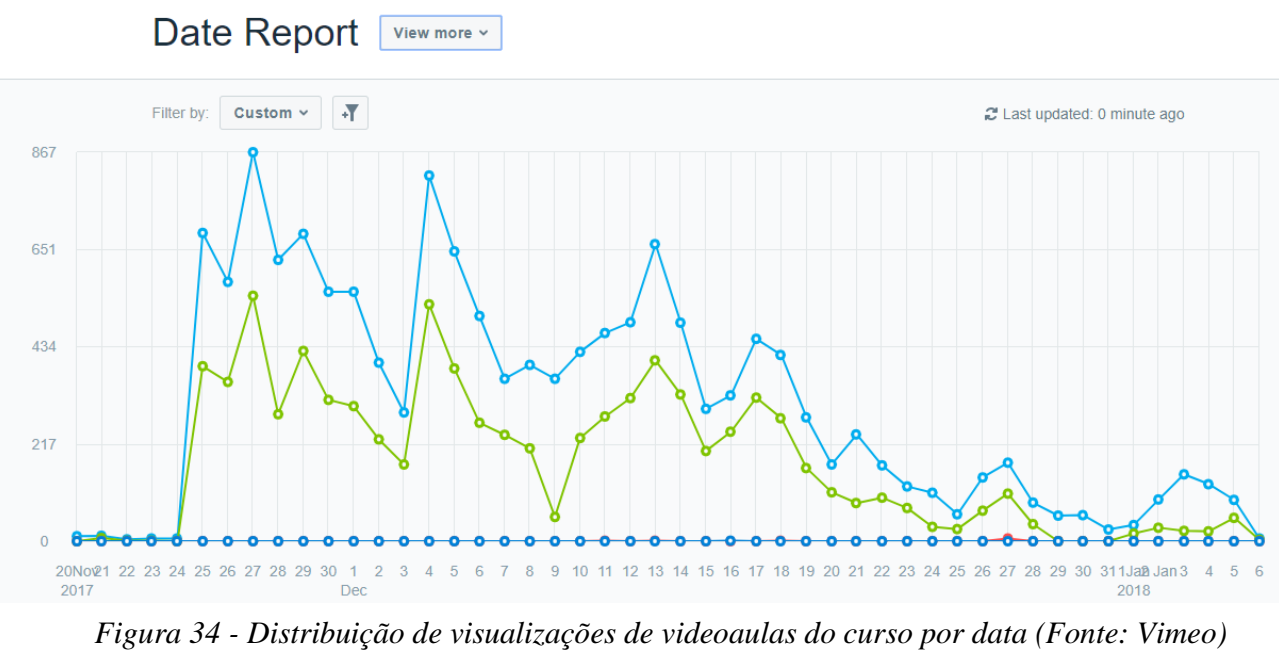

Como se pode notar na figura, houve mais plays do que términos, o que parece ser algo lógico, considerando que muitos alunos iniciam e abandonam o vídeo antes de terminar. Quanto mais próximas as linhas verde e azul, melhor. A leitura que fizemos deste gráfico mostra que, apesar de haver abandono de parte dos vídeos, houve uma taxa significativa de visualizações por completo. Ou seja, podemos afirmar que muitos alunos assistiram as videoaulas. Isso é positivo para a análise futura de relação entre as variáveis de videoaulas e o desempenho no curso. Como será explicado mais adiante na seção de análise das variáveis numéricas, os dados coletados referentes a quantidade de visualizações dos vídeos 
foram gerados a partir da quantidade de vezes que o aluno acessava a página da videoaula no curso e não a efetiva transmissão do conteúdo do vídeo. Portanto, o resultado da análise poderia estar comprometido caso os alunos não tivessem assistido aos vídeos. Felizmente, este gráfico evidencia que houve a transmissão efetiva do conteúdo das videoaulas para os alunos do curso.

Um outro indicador interessante é a ordenação das videoaulas a partir do número de visualizações, representada na figura a seguir.

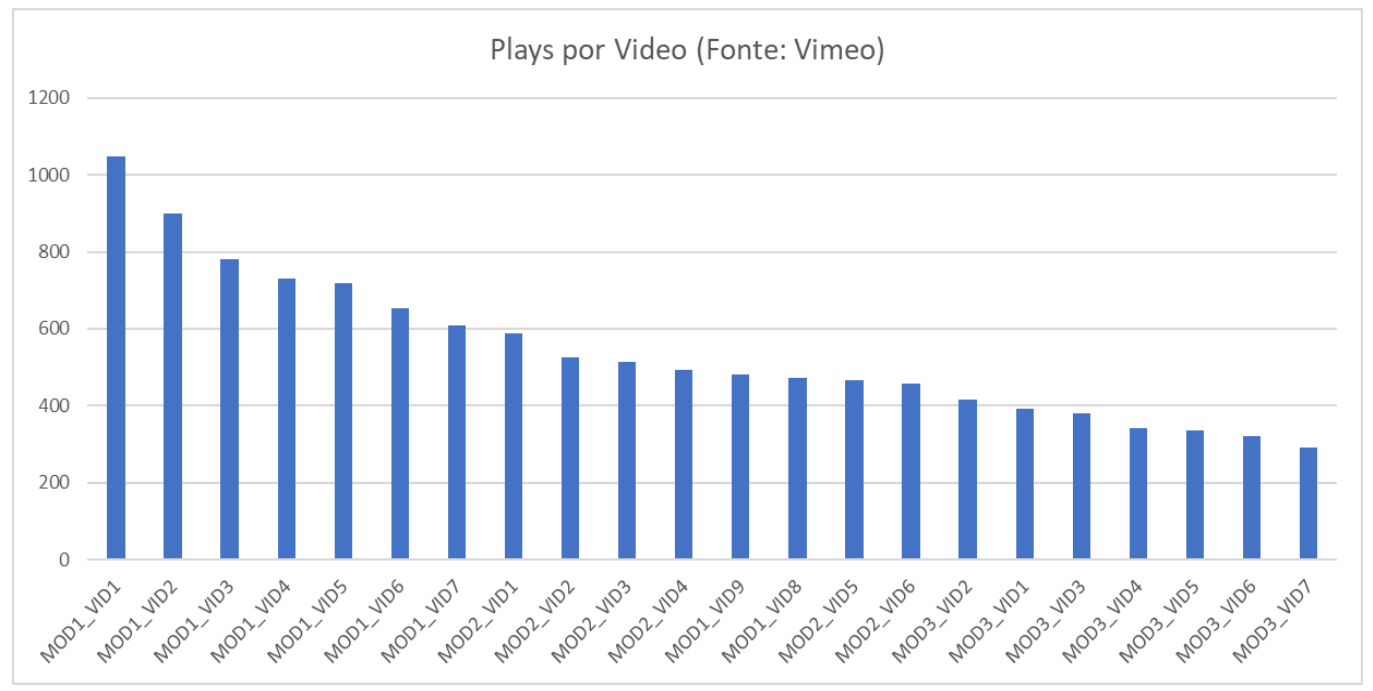

Figura 35 - Número de "plays" por videoaula do curso (Fonte: Vimeo)

Note que a ordenação ficou quase que perfeita em relação a cronologia das aulas. $\mathrm{Na}$ extrema esquerda, com maior número de visualizações, a primeira videoaula do curso (aula 1, módulo 1). As barras vão se sucedendo na mesma ordem cronológica dos vídeos até atingir na extrema direita, com o menor número de visualizações, a última videoaula do curso (aula 7, módulo 3). O formato do gráfico de barras replica uma escada descendente. Isso significa que a taxa de redução da quantidade de visualizações de vídeo se mostrou quase que perfeitamente constante ao longo do tempo de curso. Esta diminuição do grau de atenção, expressa em um curso online como visualização das videoaulas, acontece em praticamente todo tipo de curso - seja ele presencial ou à distância. O interessante é ver esta medida quantificada a partir dos registros online. Este padrão deve ser considerado para montagem do design didático em edições futuras de cursos MOOC, assim como mecanismos de retenção e estímulo a atenção que aumentam de intensidade ao longo do cronograma. Esta prescrição seria interessante para anular este efeito de redução da atenção ao longo do tempo. 
Um último indicador a ser destacado a partir dos gráficos gerados pela plataforma Vimeo é o tipo de dispositivo utilizado pelo participante do curso. A figura a seguir ilustra a distribuição entre computadores pessoais (desktops e laptops), dispositivos móveis de telefonia (smartphone) e outros dispositivos móveis (tablet). Surpreendentemente, os computadores pessoais foram, disparado, a maior fonte de visualização do curso - bem diferente das estatísticas de acesso a internet, que tem uma parcela mais bem distribuída entre os três tipos de dispositivos.

\section{Device Report view more r}

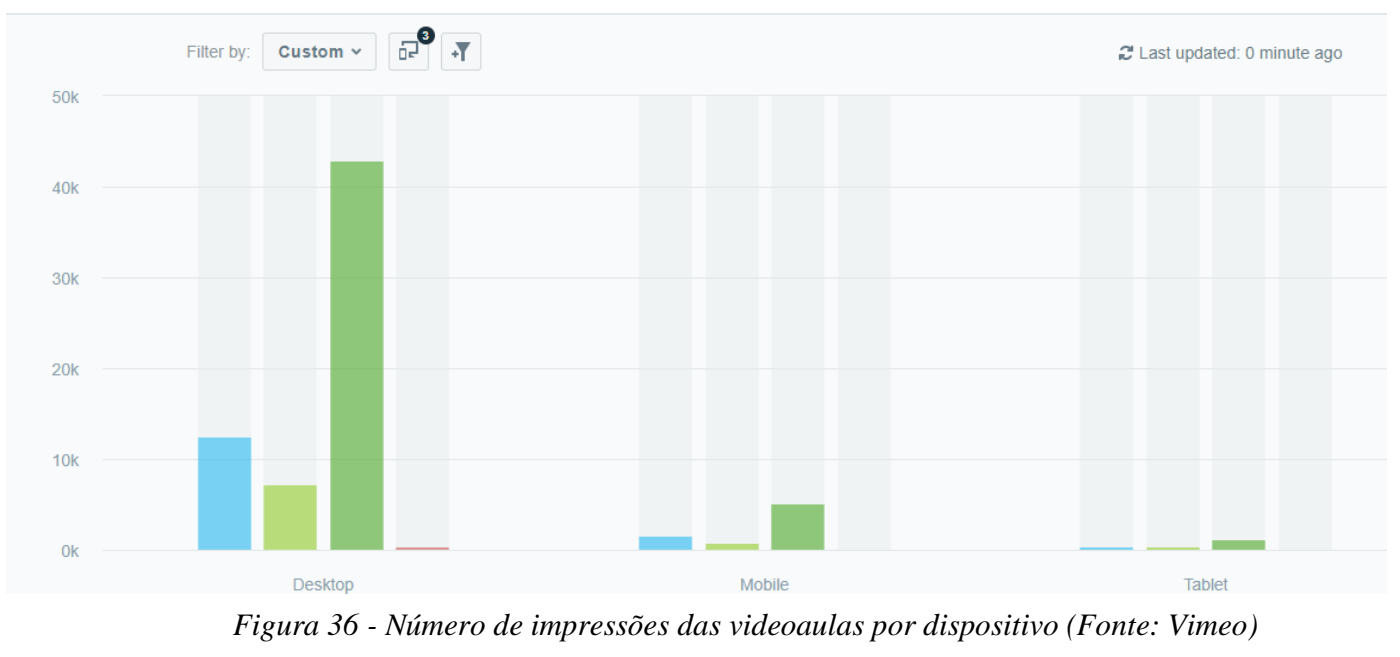

Acreditamos que isso possa ser explicado pelo fato de que os vídeos só podiam ser acessados via o ambiente virtual de aprendizagem do curso, construído em cima da plataforma Moodle. Esta plataforma é primariamente otimizada para computadores pessoais, sendo a experiência a partir de dispositivos móveis um tanto ruim.

$\mathrm{O}$ fato do acesso ser feito majoritariamente a partir de computadores pessoais, também significa que poucas pessoas fizeram o curso em trânsito, por exemplo, no transporte público ou em áreas de lazer externas. Tipicamente, os alunos do curso realizaram as atividades em locais fechados fixos como na residência ou no trabalho. Como uma sugestão de pesquisa futura, apontamos para a ideia de replicar este curso a partir de uma outra plataforma que viabilize de forma mais conveniente o acesso via dispositivos móveis. Seria interessante medir os efeitos do uso de dispositivos móveis tanto no engajamento nas atividades do curso quanto no desempenho dos alunos. 


\section{2}

\section{Teste de normalidade das variáveis numéricas}

Antes de iniciar com a análise dos resultados propriamente ditos, realizamos testes para avaliar a normalidade dos dados coletados como valores das variáveis numéricas, que são também as variáveis dependentes no estudo. Foram conduzidos dois testes para cada uma destas variáveis dependentes, com diferentes equações para avaliação da normalidade (teste qui-quadrado e Kolmogorov-Smirnov). Ambos os resultados serão apresentados e cabe notar que valores de significância abaixo de 0,05 indicam a distribuição não é normal (Asymp. Sig. $(2$-tailed) <,05). Ou seja, a hipótese nula que a variável tem distribuição normal é rejeitada se os valores de $p$ são inferiores a 0,05. Caso as distribuições não sejam normais, aplicaremos métodos de transformação dos dados para que sejam normalizados e possam ser utilizados nas análises principais.

\subsection{1}

\section{Participação nos fóruns de discussão}

<FOR_MOD1>, <FOR_MOD2> e <FOR_MOD3>

\section{Test Statistics}

\begin{tabular}{|l|r|r|r|r|}
\hline & $\begin{array}{c}\text { Participation } \\
\text { on the } \\
\text { discussion } \\
\text { forum of the } \\
\text { Module 1 }\end{array}$ & $\begin{array}{c}\text { Participation } \\
\text { on the } \\
\text { discussion } \\
\text { forum of the } \\
\text { Module 2 }\end{array}$ & $\begin{array}{c}\text { Participation } \\
\text { on the } \\
\text { discussion } \\
\text { forum of the } \\
\text { Module 3 }\end{array}$ & $\begin{array}{c}\text { Total amount } \\
\text { of forum } \\
\text { posts }\end{array}$ \\
\hline Chi-Square & $39,294^{\text {a }}$ & $122,423^{\text {a }}$ & $67,301^{\text {a }}$ & $327,028^{\text {b }}$ \\
df & 1 & 1 & 1 & 3 \\
Asymp. Sig. &, 000 &, 000 &, 000 &, 000 \\
\hline
\end{tabular}

a. 0 cells $(0,0 \%)$ have expected frequencies less than 5 . The minimum expected cell frequency is 282,5 .

b. 0 cells $(0,0 \%)$ have expected frequencies less than 5 . The minimum expected cell frequency is 141,3 .

Quadro 18 - Teste Qui-quadrado para normalidade das variáveis de participação nos fóruns do curso 
One-Sample Kolmogorov-Smirnov Test

\begin{tabular}{|ll|r|r|r|r|}
\hline & $\begin{array}{c}\text { Participation } \\
\text { on the } \\
\text { discussion } \\
\text { forum of the } \\
\text { Module 1 }\end{array}$ & $\begin{array}{c}\text { Participation } \\
\text { on the } \\
\text { discussion } \\
\text { forum of the } \\
\text { Module 2 }\end{array}$ & $\begin{array}{c}\text { Participation } \\
\text { on the } \\
\text { discussion } \\
\text { forum of the } \\
\text { Module 3 }\end{array}$ & $\begin{array}{c}\text { Total amount } \\
\text { of forum } \\
\text { posts }\end{array}$ \\
\hline N & Mean & 565 & 565 & 565 & 565 \\
Normal Parameters ${ }^{\text {a,b }}$ & Std. Deviation &, 37 &, 27 &, 33 &, 9628 \\
Most Extreme Differences & Absolute &, 483 &, 443 &, 470 & 1,24643 \\
& Positive &, 409 &, 460 &, 430 &, 336 \\
Test Statistic & Negative &,- 409 &, 460 &, 430 &, 336 \\
Asymp. Sig. (2-tailed) & &, 273 &,- 273 &,- 251 &,- 220 \\
\end{tabular}

a. Test distribution is Normal.

b. Calculated from data.

c. Lilliefors Significance Correction.

Quadro 19 - Teste KS para normalidade das variáveis de participação nos fóruns do curso

Ambos os testes apresentaram um nível de significância $\mathrm{p}<0,05$ indicando que a distribuição não é normal, portanto, para estas variáveis deve ser aplicada uma transformação de forma a aproximar os dados de uma distribuição normal, antes de rodas as análises de variância.

\section{2 .2}

\section{Tamanho das postagens nos fóruns de discussão}

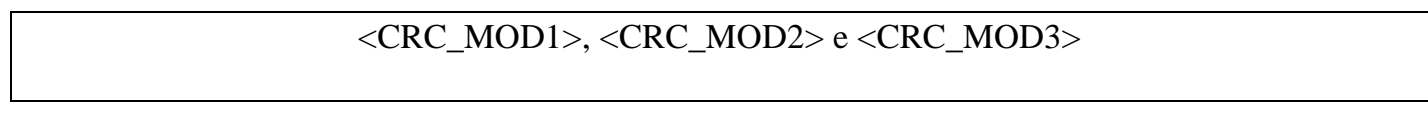

Test Statistics

\begin{tabular}{|l|r|r|r|r|}
\hline & $\begin{array}{c}\text { Amount of } \\
\text { characters } \\
\text { posted on } \\
\text { forum of the } \\
\text { Module 1 }\end{array}$ & $\begin{array}{c}\text { Amount of } \\
\text { characters } \\
\text { posted on } \\
\text { forum of the } \\
\text { Module 2 }\end{array}$ & $\begin{array}{c}\text { Amount of } \\
\text { characters } \\
\text { posted on } \\
\text { forum of the } \\
\text { Module 3 }\end{array}$ & $\begin{array}{c}\text { Total amount } \\
\text { of characters } \\
\text { on forum }\end{array}$ \\
\hline Chi-Square & $17335,283^{\mathrm{a}}$ & $17335,283^{\mathrm{a}}$ & $10958,989^{\mathrm{b}}$ & $33444,972^{\mathrm{c}}$ \\
df & 35 & 35 & 21 & 81 \\
Asymp. Sig. &, 000 &, 000 &, 000 &, 000 \\
\hline
\end{tabular}

a. 0 cells $(0,0 \%)$ have expected frequencies less than 5 . The minimum expected cell frequency is 15,7 .

b. 0 cells $(0,0 \%)$ have expected frequencies less than 5 . The minimum expected cell frequency is 25,7 .

c. 0 cells $(0,0 \%)$ have expected frequencies less than 5 . The minimum expected cell frequency is 6,9 .

Quadro 20 - Teste Qui-quadrado para normalidade das variáveis de tamanho de postagem nos fóruns do curso 
One-Sample Kolmogorov-Smirnov Test

\begin{tabular}{|ll|r|r|r|r|}
\hline & $\begin{array}{c}\text { Amount of } \\
\text { characters } \\
\text { posted on } \\
\text { forum of the } \\
\text { Module 1 }\end{array}$ & $\begin{array}{c}\text { Amount of } \\
\text { characters } \\
\text { posted on } \\
\text { forum of the } \\
\text { Module 2 }\end{array}$ & $\begin{array}{c}\text { Amount of } \\
\text { characters } \\
\text { posted on } \\
\text { forum of the } \\
\text { Module 3 }\end{array}$ & $\begin{array}{c}\text { Total amount } \\
\text { of characters } \\
\text { on forum }\end{array}$ \\
\hline N & Mean & 565 & 565 & 565 & 565 \\
Normal Parameters & a,b & 59,02 & 40,03 & 31,05 & 130,1044 \\
Most Extreme Differences & Absolute & 374,642 & 216,987 & 215,500 & 498,88567 \\
& Positive &, 501 &, 511 &, 520 &, 460 \\
Test Statistic & Negative &, 501 &, 511 &, 520 &, 460 \\
Asymp. Sig. (2-tailed) &,- 437 &,- 427 &,- 443 &,- 397 \\
\end{tabular}

a. Test distribution is Normal.

b. Calculated from data.

c. Lilliefors Significance Correction.

Quadro 21 - Teste KS para normalidade das variáveis de participação nas variáveis de tamanho das postagens

Assim como no conjunto de variáveis anteriores, ambos os testes também apresentaram um nível de significância $\mathrm{p}<0,05$ indicando que a distribuição não é normal, portanto, para estas variáveis deve ser aplicada uma transformação de forma a aproximar os dados de uma distribuição normal, antes de rodas as análises de variância.

\subsection{3}

\section{Quantidade de visualizações das videoaulas}

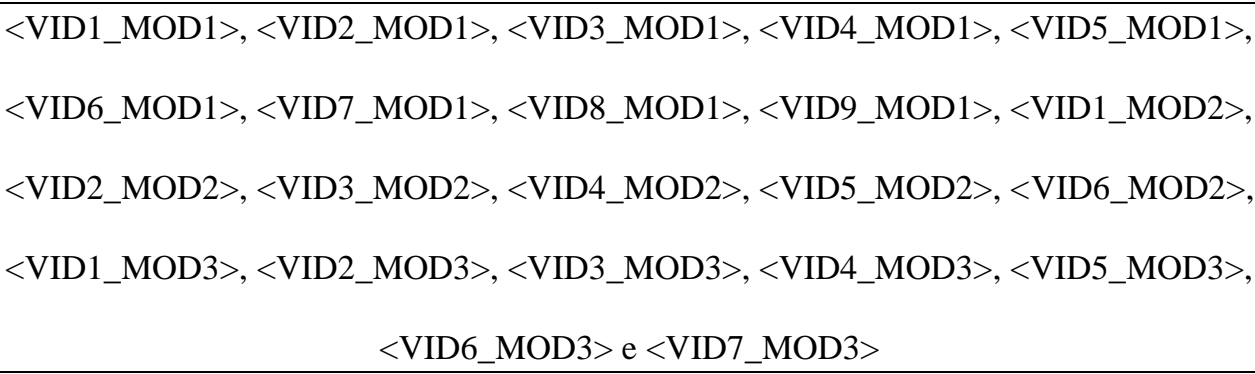


Test Statistics

\begin{tabular}{|l|r|r|r|r|}
\hline & \multicolumn{1}{|c|}{$\begin{array}{c}\text { Video } \\
\text { visualization } \\
\text { Module 1 }\end{array}$} & $\begin{array}{c}\text { Video } \\
\text { visualization } \\
\text { Module 2 }\end{array}$ & $\begin{array}{c}\text { Video } \\
\text { visualization } \\
\text { Module 3 }\end{array}$ & $\begin{array}{c}\text { Total amount } \\
\text { of videos } \\
\text { visualized }\end{array}$ \\
\hline Chi-Square & $524,133^{\mathrm{a}}$ & $2241,405^{\mathrm{b}}$ & $3949,018^{\mathrm{c}}$ & $490,965^{\mathrm{d}}$ \\
df & 63 & 30 & 35 & 91 \\
Asymp. Sig. &, 000 &, 000 &, 000 &, 000 \\
\hline
\end{tabular}

a. 0 cells $(0,0 \%)$ have expected frequencies less than 5 . The minimum expected cell frequency is 8,8 .

b. 0 cells $(0,0 \%)$ have expected frequencies less than 5 . The minimum expected cell frequency is 18,2 .

c. 0 cells $(0,0 \%)$ have expected frequencies less than 5 . The minimum expected cell frequency is 15,7 .

d. 0 cells $(0,0 \%)$ have expected frequencies less than 5 . The minimum expected cell frequency is 6,1 .

Quadro 22 - Teste Qui-quadrado para normalidade das variáveis de visualização das videoaulas do curso

One-Sample Kolmogorov-Smirnov Test

\begin{tabular}{|ll|r|r|r|r|}
\hline & \multicolumn{1}{|c|}{$\begin{array}{c}\text { Vide0 } \\
\text { visualization } \\
\text { Module 1 }\end{array}$} & $\begin{array}{c}\text { Vide0 } \\
\text { visualization } \\
\text { Module 2 }\end{array}$ & $\begin{array}{c}\text { Vide0 } \\
\text { visualization } \\
\text { Module 3 }\end{array}$ & $\begin{array}{c}\text { Total amount } \\
\text { of videos } \\
\text { visualized }\end{array}$ \\
\hline $\mathrm{N}$ & Mean & 565 & 565 & 565 & 565 \\
Normal Parameters & a,b & 17,6637 & 6,8655 & 5,7628 & 30,2920 \\
& Std. Deviation & 14,30755 & 8,54730 & 7,89966 & 26,94441 \\
Most Extreme Differences & Absolute &, 110 &, 211 &, 233 &, 130 \\
& Positive &, 110 &, 154 &, 217 &, 085 \\
Test Statistic & Negative &,- 108 &,- 211 &,- 233 &,- 130 \\
Asymp. Sig. (2-tailed) &, 110 &, 211 &, 233 &, 130 \\
\hline
\end{tabular}

a. Test distribution is Normal.

b. Calculated from data.

c. Lilliefors Significance Correction.

Quadro 23 - Teste KS para normalidade das variáveis de visualização das videoaulas do curso

Os testes de normalidade para as variáveis de visualização de vídeos também apresentaram um nível de significância $\mathrm{p}<0,05$ indicando que a distribuição não é normal, portanto, para estas variáveis também deve ser aplicada uma transformação de forma a aproximar os dados de uma distribuição normal, antes de rodas as análises de variância. 


\subsection{4}

Aprovação nos exames de avaliação

\section{$<$ AVL_MOD1>, <AVL_MOD2> e <AVL_MOD3>}

Test Statistics

\begin{tabular}{|l|r|}
\hline & $\begin{array}{r}\text { Total amount } \\
\text { of exams } \\
\text { passed }\end{array}$ \\
\hline Chi-Square & $191,637^{\text {a }}$ \\
df & 3 \\
Asymp. Sig. &, 000 \\
\hline
\end{tabular}

a. 0 cells $(0,0 \%)$ have

expected frequencies less

than 5 . The minimum

expected cell frequency is

141,3 .

One-Sample Kolmogorov-Smirnov Test

\begin{tabular}{|c|c|c|}
\hline & & $\begin{array}{c}\text { Total amount } \\
\text { of exams } \\
\text { passed }\end{array}$ \\
\hline N & & 565 \\
\hline \multirow[t]{2}{*}{ Normal Parameters ${ }^{a, b}$} & Mean & 1,4991 \\
\hline & Std. Deviation & 1,35482 \\
\hline \multirow[t]{3}{*}{ Most Extreme Differences } & Absolute &, 262 \\
\hline & Positive & 260 \\
\hline & Negative &,- 262 \\
\hline Test Statistic & &, 262 \\
\hline Asymp. Sig. (2-tailed) & &, $000^{\mathrm{c}}$ \\
\hline
\end{tabular}

a. Test distribution is Normal.

b. Calculated from data.

c. Lilliefors Significance Correction.

Quadro 25 - Teste KS para normalidade das variáveis de avaliação do curso 
Os testes da análise de normalidade aplicados na última variável de avaliação também apresentaram um nível de significância $\mathrm{p}<0,05$ indicando que a distribuição também não é normal. Portanto, para todas as variáveis dependentes associadas às atividades dos alunos no curso deverá ser aplicada uma transformação de forma a aproximar os dados de uma distribuição normal, antes de rodar as análises de variância.

\section{3}

\section{Análise da Influência de Grupo nas atividades do curso}

Nesta seção vamos aplicar técnicas de Análise da variância (ANOVA) para medir a influência do grupo Hipótese e do grupo de Controle, ambas variáveis categóricas independentes, nas atividades do curso.

Os testes de análise de variância ANOVA têm como condição a normalidade dos dados. Como atestado na seção anterior, os dados não estão normalizados, cabendo então a aplicação de algum método de transformação. O software SPSS, utilizado nesta pesquisa para computação dos resultados, disponibiliza alguns métodos de aproximação da normalidade dos dados. Utilizamos a fórmula de Blom, que realiza uma transformação matemática baseada em ranking para aproximar a distribuição de uma curva normal. Sendo assim, todas as tabelas com os resultados dos testes de variância (ANOVA) e as análises de regressões, apresentadas nas seções a seguir, já incorporam a função de transformação de Blom para aproximação da normalidade dos dados. Com relação às tabelas de apresentação das estatísticas descritivas, preservamos os dados originais, sem a transformação de normalidade para simplificar a interpretação. 


\subsection{1}

\section{Número de postagens no fórum de discussão do módulo 1}

\begin{tabular}{|c|}
\hline VARIÁVEL INDEPENDENTE: <AGRUPAME> \\
'"VARIÁVEL DEPENDENTE: $<$ FOR_MOD1> \\
\hline
\end{tabular}

Descriptive Statistics

Dependent Variable: Participation on the discussion forum of the Module 1

\begin{tabular}{|c|r|r|r|}
\hline Group & \multicolumn{1}{|c|}{ Mean } & Std. Deviation & N \\
\hline $\mathrm{H}$ &, 33 &, 471 & 260 \\
$\mathrm{C}$ &, 40 &, 491 & 305 \\
Total &, 37 &, 483 & 565 \\
\hline
\end{tabular}

Quadro 26 - Estatísticas descritivas para o número de postagens por grupo no fórum de discussão do módulo 1

Tests of Between-Subjects Effects

Dependent Variable: Normal Score of FOR_MOD1 using Blom's Formula

\begin{tabular}{|l|r|r|r|r|r|r|}
\hline Source & \multicolumn{1}{|c|}{$\begin{array}{c}\text { Type III Sum } \\
\text { of Squares }\end{array}$} & \multicolumn{1}{c|}{ df } & Mean Square & \multicolumn{1}{c|}{ F } & \multicolumn{1}{c|}{ Sig. } & \multicolumn{1}{c|}{$\begin{array}{c}\text { Partial Eta } \\
\text { Squared }\end{array}$} \\
\hline Corrected Model & $1,278^{\text {a }}$ & 1 & 1,278 & 2,897 &, 089 &, 005 \\
Intercept &, 343 & 1 &, 343 &, 778 &, 378 &, 001 \\
AGRUPAME & 1,278 & 1 & 1,278 & 2,897 &, 089 &, 005 \\
Error & 248,401 & 563 &, 441 & & & \\
Total & 250,139 & 565 & & & & \\
Corrected Total & 249,679 & 564 & & & & \\
\hline
\end{tabular}

a. $\mathrm{R}$ Squared $=, 005$ (Adjusted R Squared $=, 003$ )

Quadro 27 - Resultados da ANOVA para os efeitos de grupo nas postagens no fórum de discussão do módulo 1

A análise da variância demonstra que houve um efeito pouco significativo do grupo no número de postagens no fórum de discussão do módulo $1(\mathrm{~F}(1,563)=$ 2,897, $\mathrm{p}=0,089)$. Entretanto, a designação do participante em um dos dois grupos explica somente $0,5 \%$ da variância no número de postagens $(\eta 2=0,005)$. Considerando que a homogeneidade das variâncias é uma das condições para se tirar conclusões sobre uma ANOVA e a mesma não foi atingida ( $F$ de Levene $(1,563)=11,533, p=0,01)$, conduzimos um Teste $t$ para amostras independentes de forma a ter certeza que o efeito dos grupos foi marginal. Este teste provê correção dos graus de liberdade (DF) permitindo assim conclusões não distorcidas por variâncias não homogêneas. 


\begin{tabular}{|c|c|c|c|c|c|c|c|c|c|c|}
\hline \multicolumn{11}{|c|}{ Independent Samples Test } \\
\hline & & \multicolumn{2}{|c|}{$\begin{array}{l}\text { Levene's Test for Equality of } \\
\text { Variances }\end{array}$} & \multicolumn{7}{|c|}{ t-test for Equality of Means } \\
\hline & & \multirow[b]{2}{*}{$\mathrm{F}$} & \multirow[b]{2}{*}{ Sig. } & \multirow[b]{2}{*}{$t$} & \multirow[b]{2}{*}{ df } & \multirow[b]{2}{*}{ Sig. (2-tailed) } & \multirow{2}{*}{$\begin{array}{l}\text { Mean } \\
\text { Differencen }\end{array}$} & \multirow{2}{*}{$\begin{array}{l}\text { Std. Error } \\
\text { Difference }\end{array}$} & \multicolumn{2}{|c|}{$\begin{array}{l}\text { 95\% Confidence Interval of the } \\
\text { Difference }\end{array}$} \\
\hline & & & & & & & & & Lower & Upper \\
\hline \multirow{2}{*}{$\begin{array}{l}\text { Patricipation on the } \\
\text { discussion forum of the } \\
\text { Module } 1\end{array}$} & $\begin{array}{l}\text { Equal variances } \\
\text { assumed }\end{array}$ & \multirow[t]{2}{*}{11,533} & \multirow[t]{2}{*}{.001 } & 1,702 & 563 & . 089 & .069 & .041 & . & 149 \\
\hline & $\begin{array}{l}\text { Equal variances not } \\
\text { assumed }\end{array}$ & & & 1,707 & 555,012 & ,088 & ,069 & ,041 & . & ,149 \\
\hline
\end{tabular}

Quadro 28 - Resultados do Teste t para participação por grupo no fórum de discussão do módulo 1

O Teste $\mathrm{t}$ replicou os resultados da ANOVA com $\mathrm{t}(555,012)=1,707 \mathrm{e} \mathrm{p}=$ 0,088 .

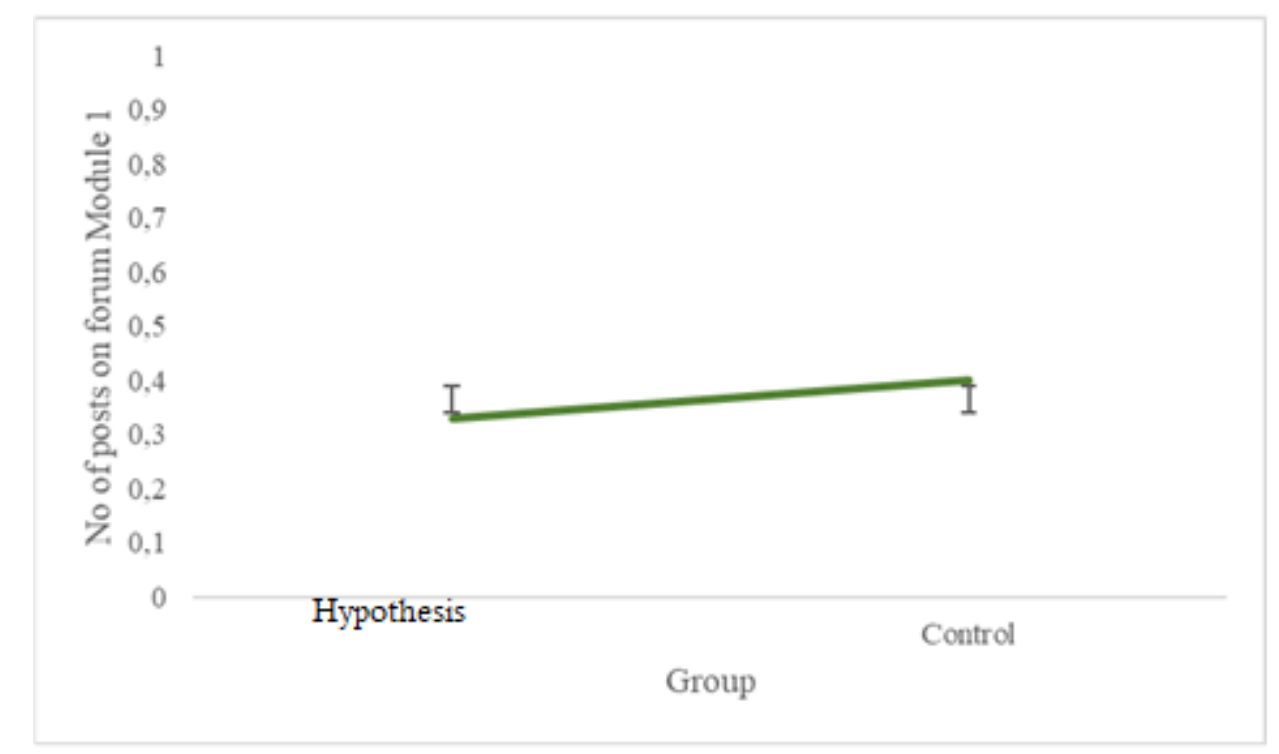

Figura 37 - Diferença entre os grupos no total de postagens no fórum de discussão do módulo 1

\subsection{2}

Número de postagens no fórum de discussão do módulo 2

\section{VARIÁVEL INDEPENDENTE: <AGRUPAME> \\ VARIÁVEL DEPENDENTE: <FOR_MOD2>}

\section{Descriptive Statistics}

Dependent Variable: Participation on the discussion forum of the Module 2

\begin{tabular}{|c|r|r|r|}
\hline Group & \multicolumn{1}{|c|}{ Mean } & Std. Deviation & N \\
\hline $\mathrm{H}$ &, 22 &, 417 & 260 \\
$\mathrm{C}$ &, 30 &, 461 & 305 \\
Total &, 27 &, 443 & 565 \\
\hline
\end{tabular}

Quadro 29 - Estatísticas descritivas para o mimero de postagens por grupo no fórum de discussão do módulo 2 
Tests of Between-Subjects Effects

Dependent Variable: Normal Score of FOR_MOD2 using Blom's Formula

\begin{tabular}{|l|r|r|r|r|r|r|}
\hline Source & \multicolumn{1}{|c|}{$\begin{array}{c}\text { Type III Sum } \\
\text { of Squares }\end{array}$} & \multicolumn{1}{c|}{ df } & Mean Square & F & \multicolumn{1}{c|}{ Sig. } & \multicolumn{1}{c|}{$\begin{array}{c}\text { Sartial Eta } \\
\text { Squared }\end{array}$} \\
\hline Corrected Model & $1,976^{\text {a }}$ & 1 & 1,976 & 4,825 &, 028 &, 008 \\
Intercept &, 965 & 1 &, 965 & 2,357 &, 125 &, 004 \\
AGRUPAME & 1,976 & 1 & 1,976 & 4,825 &, 028 &, 008 \\
Error & 230,644 & 563 &, 410 & & & \\
Total & 233,826 & 565 & & & & \\
Corrected Total & 232,621 & 564 & & & & \\
\hline
\end{tabular}

Quadro 30 - Resultados da ANOVA para os efeitos de grupo nas postagens no fórum de discussão do módulo 2

A análise da variância mostrou uma diferença significativa entre os grupos no número de postagens no fórum de discussão do módulo $2(\mathrm{~F}(1,563)=4,825, \mathrm{p}=$ 0,028). Entretanto, a designação do participante em um dos dois grupos explicou somente $0,8 \%$ da variância no número de postagens $(\eta 2=0,008)$, o que significa que, apesar de existente, o efeito grupo não deveria ser considerado. Similar a análise anterior com a variável <FOR_MOD1〉, a homogeneidade não foi atingida $(F$ de Levene $(1,563)=19.933, \mathrm{p}=0,00)$. Sendo assim conduzimos um Teste $\mathrm{t}$ com correção dos graus de liberdade (DF), confirmando os resultados da ANOVA com $\mathrm{t}(561,006)=2,214$ e $\mathrm{p}=0,027$.

\begin{tabular}{|c|c|c|c|c|c|c|c|c|c|c|}
\hline \multicolumn{11}{|c|}{ Independent Samples Test } \\
\hline & & \multicolumn{2}{|c|}{$\begin{array}{l}\text { Levene's Test for Equality of } \\
\text { Variances }\end{array}$} & \multicolumn{7}{|c|}{ t-test for Equality of Means } \\
\hline & & \multirow{2}{*}{ 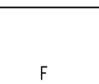 } & \multirow[b]{2}{*}{ Sig. } & \multirow[b]{2}{*}{$t$} & \multirow[b]{2}{*}{ df } & \multirow[b]{2}{*}{ Sig. (2-tailed) } & \multirow{2}{*}{$\begin{array}{c}\text { Mean } \\
\text { Difference }\end{array}$} & \multirow{2}{*}{$\begin{array}{l}\text { Std. Error } \\
\text { Difference }\end{array}$} & \multicolumn{2}{|c|}{$\begin{array}{l}95 \% \text { Confidence Interval of the } \\
\text { Difference }\end{array}$} \\
\hline & & & & & & & & & Lower & Upper \\
\hline $\begin{array}{l}\text { Participation on the } \\
\text { discussion forum of the }\end{array}$ & $\begin{array}{l}\text { Equal variances } \\
\text { assumed }\end{array}$ & \multirow[t]{2}{*}{19,933} & \multirow[t]{2}{*}{, 000} & 2,196 & 563 & .028 & 082 & , 037 & .009 &, 155 \\
\hline Module 2 & $\begin{array}{l}\text { Equal variances not } \\
\text { assumed }\end{array}$ & & & 2,214 & 561,006 & .027 & .082 & .037 & .009 &, 154 \\
\hline
\end{tabular}

Quadro 31 - Resultados do Teste t para participação por grupo no fórum de discussão do módulo 2

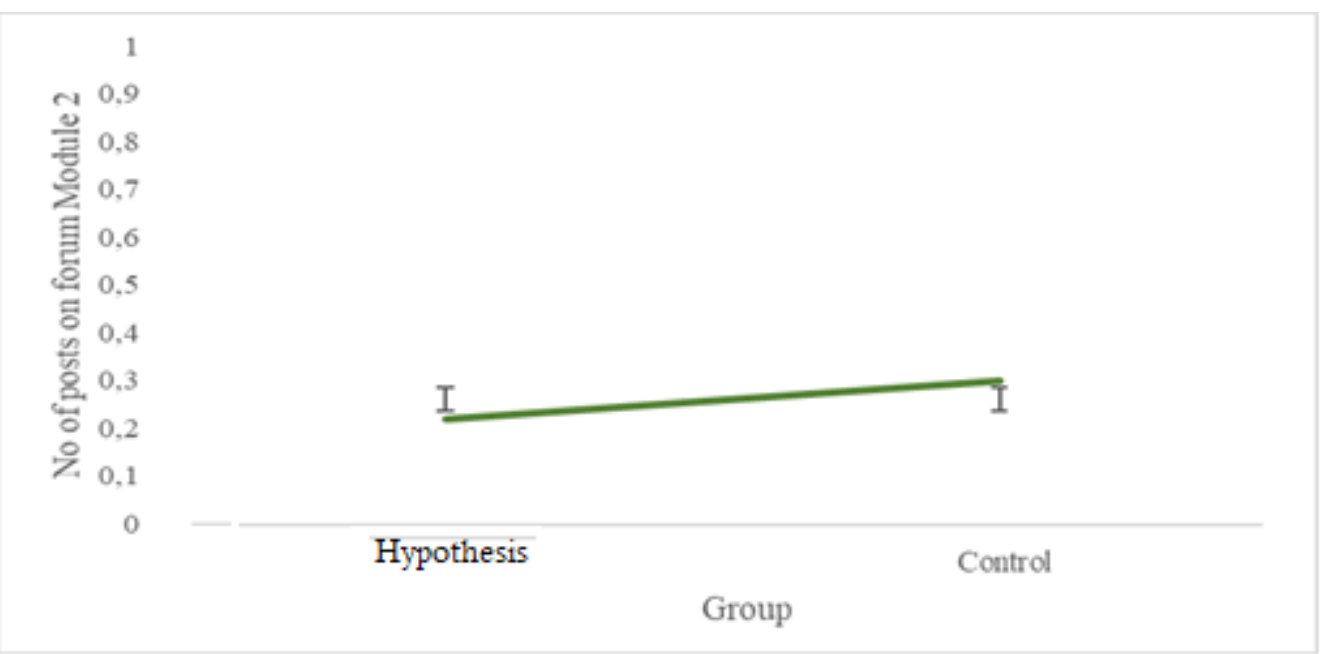

Figura 38 - Diferença entre os grupos no total de postagens no fónum de discussão do módulo 2 


\subsection{3}

\section{Número de postagens no fórum de discussão do módulo 3}

\begin{tabular}{|c|}
\hline VARIÁVEL INDEPENDENTE: $<$ AGRUPAME > \\
VARIÁVEL_DEPENDENTE: $<$ FOR_MOD3> \\
\hline
\end{tabular}

\section{Descriptive Statistics}

Dependent Variable: Participation on the discussion forum of the Module 3

\begin{tabular}{|l|r|r|r|}
\hline Group & \multicolumn{1}{|c|}{ Mean } & Std. Deviation & N \\
\hline Habermasian &, 28 &, 448 & 260 \\
Control &, 37 &, 484 & 305 \\
Total &, 33 &, 470 & 565 \\
\hline
\end{tabular}

Quadro 32 - Estatísticas descritivas para o número de postagens por grupo no fórum de discussão do módulo 3

Tests of Between-Subjects Effects

Dependent Variable: Rank of FOR_MOD3

\begin{tabular}{|l|r|r|r|r|r|r|}
\hline Source & \multicolumn{1}{|c|}{$\begin{array}{c}\text { Type III Sum } \\
\text { of Squares }\end{array}$} & df & Mean Square & \multicolumn{1}{c|}{ F } & \multicolumn{1}{c|}{ Sig. } & \multicolumn{1}{c|}{$\begin{array}{c}\text { Partial Eta } \\
\text { Squared }\end{array}$} \\
\hline Corrected Model & $98067,043^{\text {a }}$ & 1 & 98067,043 & 5,616 &, 018 &, 010 \\
Intercept & 44629371,47 & 1 & 44629371,47 & 2555,617 &, 000 &, 819 \\
AGRUPAME & 98067,043 & 1 & 98067,043 & 5,616 &, 018 &, 010 \\
Error & 9831807,957 & 563 & 17463,247 & & & \\
Total & 55180160,00 & 565 & & & & \\
Corrected Total & 9929875,000 & 564 & & & & \\
\hline
\end{tabular}

a. $R$ Squared $=, 010$ (Adjusted $R$ Squared $=, 008$ ) módulo 3

Quadro 33 - Resultados da ANOVA para os efeitos de grupo nas postagens no fórum de discussão do

Os resultados da ANOVA demonstraram um padrão similar à variável anterior. O efeito do agrupamento no total de postagens do fórum de discussão do módulo 3 foi significativo $(\mathrm{F}(1,563)=5.616, \mathrm{p}=0,018)$, tendo sido maior que nos outros dois módulos anteriores, mas ainda muito modesto pois explicou somente $1 \%$ da variância no número de postagens $(\eta 2=0,01)$. Considerando que a variância foi novamente heterogênea $(F$ de Levene $(1,563)=22.729, \mathrm{p}=0,000)$, conduzimos um Teste $\mathrm{t}$ com correção dos graus de liberdade. 


\begin{tabular}{|c|c|c|c|c|c|c|c|c|c|c|}
\hline \multicolumn{11}{|c|}{ Independent Samples Test } \\
\hline & & \multicolumn{2}{|c|}{$\begin{array}{l}\text { Levene's Test for Equality of } \\
\text { Variances }\end{array}$} & \multicolumn{7}{|c|}{ t-test for Equality of Means } \\
\hline & & \multirow[b]{2}{*}{$\mathrm{F}$} & \multirow[b]{2}{*}{ Sig. } & \multirow[b]{2}{*}{$t$} & \multirow[b]{2}{*}{ df } & \multirow[b]{2}{*}{ Sig. (2-tailed) } & \multirow{2}{*}{$\begin{array}{l}\text { Mean } \\
\text { Difference }\end{array}$} & \multirow{2}{*}{$\begin{array}{l}\text { Std. Error } \\
\text { Difference }\end{array}$} & \multicolumn{2}{|c|}{$\begin{array}{l}\text { 95\% Confidence Inteval of the } \\
\text { Difference }\end{array}$} \\
\hline & & & & & & & & & Lower & Upper \\
\hline $\begin{array}{l}\text { Participation on the } \\
\text { discussion forum of the }\end{array}$ & $\begin{array}{l}\text { Equal variances } \\
\text { assumed }\end{array}$ & 22,729 & , 000 & 2,370 & 563 & . 018 & ,094 & , 039 & .016 & 171 \\
\hline Module 3 & $\begin{array}{l}\text { Equal variances not } \\
\text { assumed }\end{array}$ & & & 2,384 & 559,052 & . 017 & ,094 & ,039 & ,016 & 171 \\
\hline
\end{tabular}

Quadro 34 - Resultados do Teste t para participação por grupo no fórum de discussão do módulo 3

O Teste $\mathrm{t}$ replicou os resultados da ANOVA com $\mathrm{t}(559,052)=2,384$ e $\mathrm{p}=$ 0,17 , confirmando que os estudantes alocados no grupo de controle postaram significativamente mais que os estudantes do grupo Hipótese.

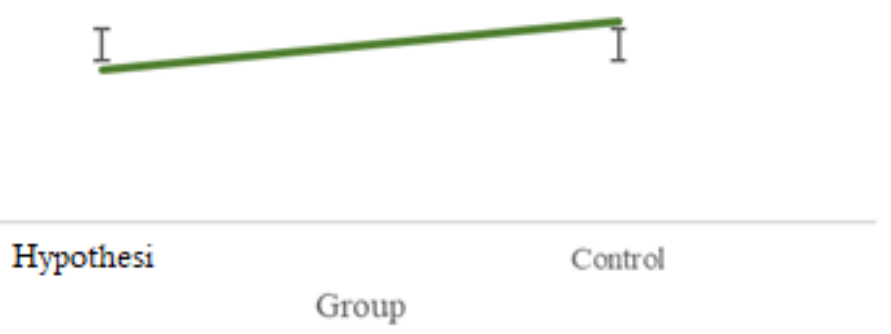

Figura 39 - Diferença entre os grupos no total de postagens no fónum de discussão do módulo 3

\subsection{4}

Número total de postagens em todos os fóruns de discussão

VARIÁ VEL INDEPENDENTE: <AGRUPAME>
VARIÁVEL DEPENDENTE: SOMA DAS VARIÁVEIS <FOR_MOD1 >, <FOR_MOD2>,
<FOR_MOD3>

\section{Descriptive Statistics}

Dependent Variable: Total amount of forum posts
\begin{tabular}{|l|r|r|r|}
\hline Group & \multicolumn{1}{|c|}{ Mean } & Std. Deviation & \multicolumn{1}{c|}{ N } \\
\hline H &, 8308 & 1,17331 & 260 \\
C & 1,0754 & 1,29684 & 305 \\
Total &, 9628 & 1,24643 & 565 \\
\hline
\end{tabular}

Quadro 35 - Estatisticas descritivas para o mimero total de postagens por grupo nos fóruns de discussão dos módulos 1,2 e 3 
Tests of Between-Subjects Effects

Dependent Variable: Normal Score of FOR_TOT using Blom's Formula

\begin{tabular}{|l|r|r|r|r|r|r|}
\hline Source & \multicolumn{1}{|c|}{$\begin{array}{c}\text { Type III Sum } \\
\text { of Squares }\end{array}$} & df & Mean Square & F & Sig. & $\begin{array}{c}\text { Partial Eta } \\
\text { Squared }\end{array}$ \\
\hline Corrected Model & $2,850^{\mathrm{a}}$ & 1 & 2,850 & 5,120 &, 024 &, 009 \\
Intercept &, 598 & 1 &, 598 & 1,074 &, 301 &, 002 \\
AGRUPAME & 2,850 & 1 & 2,850 & 5,120 &, 024 &, 009 \\
Error & 313,332 & 563 &, 557 & & & \\
Total & 317,011 & 565 & & & & \\
Corrected Total & 316,182 & 564 & & & & \\
\hline
\end{tabular}

a. R Squared $=, 009$ (Adjusted R Squared $=, 007$ )

Quadro 36 - Resultados da ANOVA para os efeitos de grupo nas postagens nos fóruns de discussão dos módulos 1, 2 e 3

Como era de se esperar, baseado nas análises prévias, a ANOVA mostrou que houve uma diferença significativa no total de postagens entre os grupos $(\mathrm{F}(1,563)=5,120, \mathrm{p}=0,024)$, entretanto, o grupo explicou somente $1 \%$ da variância no número de postagens $(\eta 2=0,01)$. Assim como nas análises prévias, a homogeneidade da variância não foi obtida $(F$ de Levene $(1,563)=8,998, \mathrm{p}=$ 0,003) e por isso conduzimos um Teste t com correção dos graus de liberdade para variâncias heterogêneas.

\begin{tabular}{|c|c|c|c|c|c|c|c|c|c|c|}
\hline \multicolumn{11}{|c|}{ Independent Samples Test } \\
\hline & & \multicolumn{2}{|c|}{$\begin{array}{l}\text { Levene's Test for Equality of } \\
\text { Variances }\end{array}$} & \multicolumn{7}{|c|}{ t-test for Equality of Means } \\
\hline & & \multirow[b]{2}{*}{$\mathrm{F}$} & \multirow[b]{2}{*}{ Sig. } & \multirow[b]{2}{*}{$t$} & \multirow[b]{2}{*}{ df } & \multirow[b]{2}{*}{ Sig. (2-tailed) } & \multirow{2}{*}{$\begin{array}{c}\text { Mean } \\
\text { Difference }\end{array}$} & \multirow{2}{*}{$\begin{array}{l}\text { Std. Error } \\
\text { Difference }\end{array}$} & \multicolumn{2}{|c|}{$\begin{array}{l}95 \% \text { Confidence Interval of the } \\
\text { Difference }\end{array}$} \\
\hline & & & & & & & & & Lower & Upper \\
\hline $\begin{array}{l}\text { Total amount of forum } \\
\text { posts }\end{array}$ & $\begin{array}{l}\text { Equal variances } \\
\text { assumed }\end{array}$ & 8,998 & ,003 & 2,334 & 563 &, 020 & ,24464 & 10480 & ,03880 & .45048 \\
\hline & $\begin{array}{l}\text { Equal variances not } \\
\text { assumed }\end{array}$ & & & 2,353 & 560,991 & .019 & ,24464 & 10397 & ,04043 & .44885 \\
\hline
\end{tabular}

Quadro 37 - Resultados do Teste t para participação por grupo no fórum de discussão dos módulos 1,2 e 3

Os resultados da ANOVA foram replicados, destacando que o grupo de controle teve mais postagens que o grupo com o Mediador $(\mathrm{t}(560,991)=2,353$; $\mathrm{p}$ $=0,019)$. 


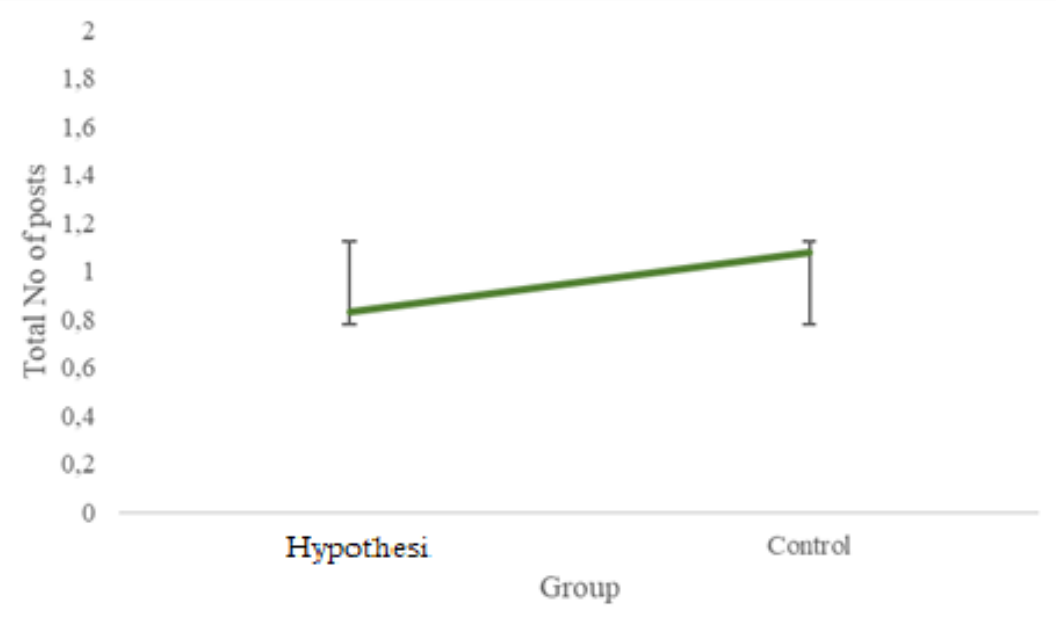

Figura 40 - Diferença entre os grupos no total de postagens no fórum de discussão dos módulol, 2 e 3

\subsection{5}

\section{Tamanho dos posts no fórum de discussão do módulo 1}

\section{VARIÁVEL INDEPENDENTE: 〈AGRUPAME〉}

VARIÁVEL DEPENDENTE: 〈CRC_MOD1>

\section{Descriptive Statistics}

Dependent Variable: Amount of characters posted on forum of the Module 1

\begin{tabular}{|l|r|r|r|}
\hline Group & \multicolumn{1}{|c|}{ Mean } & Std. Deviation & N \\
\hline H & 17,70 & 101,623 & 260 \\
C & 94,25 & 498,894 & 305 \\
Total & 59,02 & 374,642 & 565 \\
\hline
\end{tabular}

Quadro 38 - Estatisticas descritivas para o tamanho das postagens por grupo no förum de discussão do módulo I

\section{Tests of Between-Subjects Effects}

Dependent Variable: Normal Score of CRC_MOD1 using Blom's Formula

\begin{tabular}{|l|r|r|r|r|r|r|}
\hline Source & \multicolumn{1}{|c|}{$\begin{array}{c}\text { Type III Sum } \\
\text { of Squares }\end{array}$} & df & Mean Square & F & \multicolumn{1}{c|}{ Sig. } & $\begin{array}{c}\text { Partial Eta } \\
\text { Squared }\end{array}$ \\
\hline Corrected Model &, $835^{\text {a }}$ & 1 &, 835 & 3,348 &, 068 &, 006 \\
Intercept & 1,169 & 1 & 1,169 & 4,686 &, 031 &, 008 \\
AGRUPAME &, 835 & 1 &, 835 & 3,348 &, 068 &, 006 \\
Error & 140,422 & 563 &, 249 & & & \\
Total & 142,597 & 565 & & & & \\
Corrected Total & 141,257 & 564 & & & & \\
\hline
\end{tabular}

a. $\mathrm{R}$ Squared $=, 006$ (Adjusted R Squared $=, 004$ )

Quadro 39 - Resultados da ANOVA para os efeitos de grupo no tamanho das postagens no fórum de discussão do módulo 1 
Assim como no bloco anterior de análise da variância na quantidade de postagens, essa próxima sequência associada ao tamanho das postagens demonstrou resultado muito parecido. Nesta primeira variável pode-se perceber uma diferença marginal entre os grupos $(F(1,563)=3,348, p=0,068)$, explicando somente $0,6 \%$ da variância $\left(\eta^{2}=0,06\right)$. Devido à falta de homogeneidade nas variâncias $(F$ de Levene $(1,563)=22,717, p=0,000)$, conduzimos o Teste $\mathrm{t}$ com correção dos graus de liberdade e ficou evidenciado que os participantes do grupo de controle postaram significativamente mais que os participantes do grupo Hipótese $(t(333,387)=2,617, p=0,009)$.

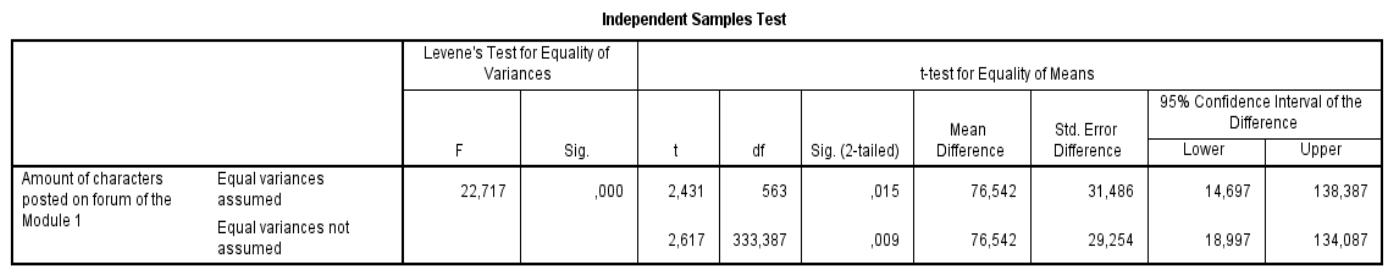
módulo 1

Quadro 40 - Resultados do Teste t para tamanho das postagens por grupo no fórum de discussão do

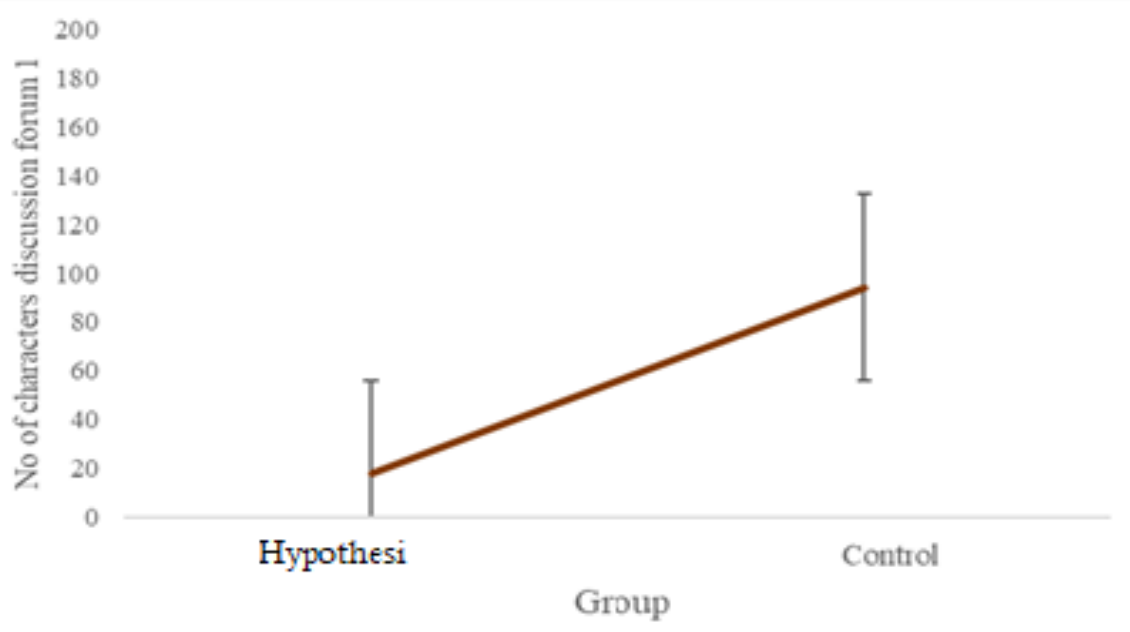

Figura 41 - Diferença entre os grupos no tamanho das postagens no fórum de discussão do módulo 1 


\title{
6.3.6
}

\section{Tamanho dos posts no fórum de discussão do módulo 2}

\author{
VARIÁVEL INDEPENDENTE: <AGRUPAME> \\ VARIÁVEL DEPENDENTE: <CRC_MOD2>
}

\section{Descriptive Statistics}

Dependent Variable: Amount of characters posted on forum of the Module 2

\begin{tabular}{|l|c|r|rr|}
\hline Group & Mean & Std. Deviation & N \\
\hline H & 12,70 & 73,422 & & 260 \\
C & 63,33 & 285,614 & 305 \\
Total & 40,03 & 216,987 & 565 \\
\hline
\end{tabular}

Quadro 4l - Estatísticas descritivas para o tamanho das postagens por grupo no förum de discussão do módulo 2

Tests of Between-Subjects Effects

Dependent Variable: Normal Score of CRC_MOD2 using Blom's Formula

\begin{tabular}{|l|r|r|r|r|r|r|}
\hline Source & \multicolumn{1}{|c|}{$\begin{array}{c}\text { Type III Sum } \\
\text { of Squares }\end{array}$} & \multicolumn{1}{c|}{ df } & Mean Square & F & Sig. & \multicolumn{1}{c|}{$\begin{array}{c}\text { Partial Eta } \\
\text { Squared }\end{array}$} \\
\hline Corrected Model & $1,795^{\text {a }}$ & 1 & 1,795 & 7,248 &, 007 &, 013 \\
Intercept & 1,097 & 1 & 1,097 & 4,427 &, 036 &, 008 \\
AGRUPAME & 1,795 & 1 & 1,795 & 7,248 &, 007 &, 013 \\
Error & 139,462 & 563 &, 248 & & & \\
Total & 142,597 & 565 & & & & \\
Corrected Total & 141,257 & 564 & & & & \\
\hline
\end{tabular}

a. R Squared $=, 013$ (Adjusted R Squared $=, 011$ )

Quadro 42 - Resultados da ANOVA para os efeitos de grupo no tamanho das postagens no fórum de discussão do módulo 2

A ANOVA demonstrou que houve uma diferença significativa no tamanho das postagens entre os grupos $(F(1,563)=7,248, p=0,007)$, mas eles explicam somente $1,3 \%$ da variância $\left(\eta^{2}=0,013\right)$. Como a condição de homogeneidade não foi atingida $(F$ de Levene $(1,563)=30,160, p=0,000)$, conduzimos o Teste $t$ com correção dos graus de liberdade.

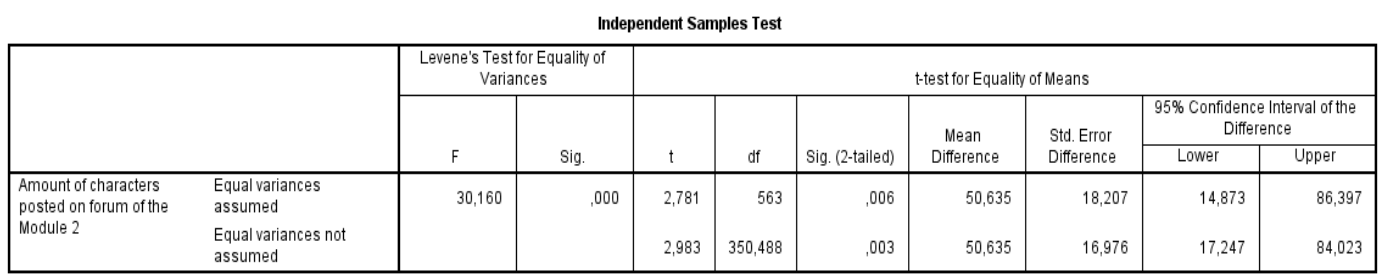
módulo 2

Quadro 43 - Resultados do Teste t para tamanho das postagens por grupo no fórum de discussão do 
A partir dos resultados do teste, ficou confirmado que os participantes do grupo de controle realizaram postagens significativamente maiores que os participantes do grupo Hipótese $(t(350,488)=2,983, p=0,003)$.

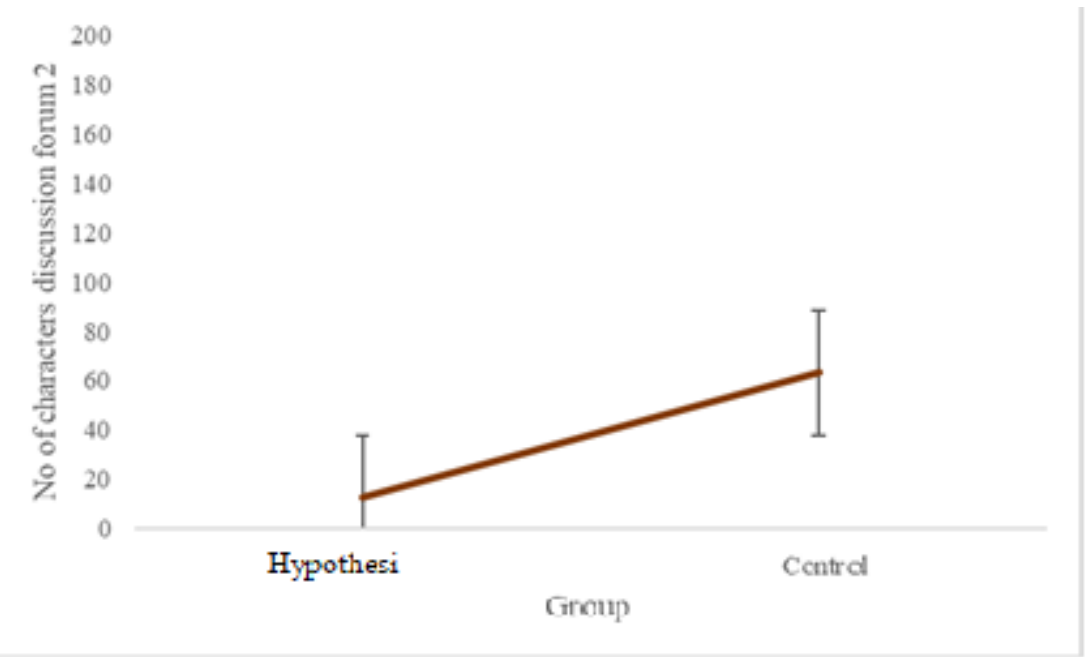

Figura 42 - Diferença entre os grupos no tamanho das postagens no fórum de discussão do módulo 2

\subsection{7}

Tamanho dos posts no fórum de discussão do módulo 3

\begin{tabular}{l} 
VARIÁVEL INDEPENDENTE: <AGRUPAME> \\
VARIÁVEL DEPENDENTE: <CRC_MOD3> \\
\hline
\end{tabular}

\section{Descriptive Statistics}

Dependent Variable: Amount of characters posted on forum of the Module 3

\begin{tabular}{|l|r|r|r|}
\hline Group & \multicolumn{1}{|c|}{ Mean } & Std. Deviation & \multicolumn{1}{|c|}{} \\
\hline H & 42,00 & 246,989 & 260 \\
C & 21,71 & 184,378 & 305 \\
Total & 31,05 & 215,500 & 565 \\
\hline
\end{tabular}

Quadro 44 - Estatisticas descritivas para o tamanho das postagens por grupo no förum de discussão do módulo 3

Tests of Between-Subjects Effects

Dependent Variable: Normal Score of CRC_MOD3 using Blom's Formula

\begin{tabular}{|l|r|r|r|r|r|r|}
\hline Source & $\begin{array}{c}\text { Type III Sum } \\
\text { of Squares }\end{array}$ & df & Mean Square & F & Sig. & $\begin{array}{c}\text { Partial Eta } \\
\text { Squared }\end{array}$ \\
\hline Corrected Model &, $375^{\text {a }}$ & 1 &, 375 & 2,083 &, 149 &, 004 \\
Intercept &, 805 & 1 &, 805 & 4,476 &, 035 &, 008 \\
AGRUPAME &, 375 & 1 &, 375 & 2,083 &, 149 &, 004 \\
Error & 101,238 & 563 &, 180 & & & \\
Total & 102,337 & 565 & & & & \\
Corrected Total & 101,613 & 564 & & & & \\
\hline
\end{tabular}

a. R Squared $=, 004$ (Adjusted R Squared $=, 002$ )

Quadro 45 - Resultados da ANOVA para os efeitos de grupo no tamanho das postagens no fórum de discussão do módulo 3 
A análise da variância não demonstrou nenhum efeito significativo de grupo no tamanho das postagens no fórum de discussão do módulo $3(F(1,563)=$ $2,083, p=0,149)$. Para nos certificar que a ausência de diferença entre grupos não foi causada pela heterogeneidade da variância $(F$ de Levene $(1,563)=4,647, p=$ 0,032), rodamos o Teste t.

\begin{tabular}{|c|c|c|c|c|c|c|c|c|c|c|}
\hline \multicolumn{11}{|c|}{ Independent Samples Test } \\
\hline & & \multicolumn{2}{|c|}{$\begin{array}{l}\text { Levene's Test for Equality of } \\
\text { Variances }\end{array}$} & \multicolumn{7}{|c|}{ t-test for Equality of Means } \\
\hline & & \multirow[b]{2}{*}{$\mathrm{F}$} & \multirow[b]{2}{*}{ sig. } & \multirow[b]{2}{*}{$t$} & \multirow[b]{2}{*}{ df } & \multirow[b]{2}{*}{ Sig. (2-tailed) } & \multirow{2}{*}{$\begin{array}{c}\text { Mean } \\
\text { Difference }\end{array}$} & \multirow{2}{*}{$\begin{array}{l}\text { Std. Error } \\
\text { Difference }\end{array}$} & \multicolumn{2}{|c|}{$\begin{array}{l}\text { 95\% Confidence Interval of the } \\
\text { Difference }\end{array}$} \\
\hline & & & & & & & & & Lower & Upper \\
\hline \multirow{2}{*}{$\begin{array}{l}\text { Amount of characters } \\
\text { posted on forum of the } \\
\text { Module } 3\end{array}$} & $\begin{array}{l}\text { Equal variances } \\
\text { assumed }\end{array}$ & \multirow[t]{2}{*}{4,647} & \multirow[t]{2}{*}{, 032} & $-1,116$ & 563 &, 265 & $-20,289$ & 18,186 & $-56,010$ & 15,432 \\
\hline & $\begin{array}{l}\text { Equal variances not } \\
\text { assumed }\end{array}$ & & & $-1,091$ & 472,649 &, 276 & $-20,289$ & 18,604 & $-56,845$ & 16,267 \\
\hline
\end{tabular}

Quadro 46 - Resultados do Teste t para tamanho das postagens por grupo no fórum de discussão do módulo 3

O Teste t confirmou que não houve diferença significativa entre os grupos de Controle e o grupo com o Mediador $(t(472,649)=-1,091, p=0,276)$.

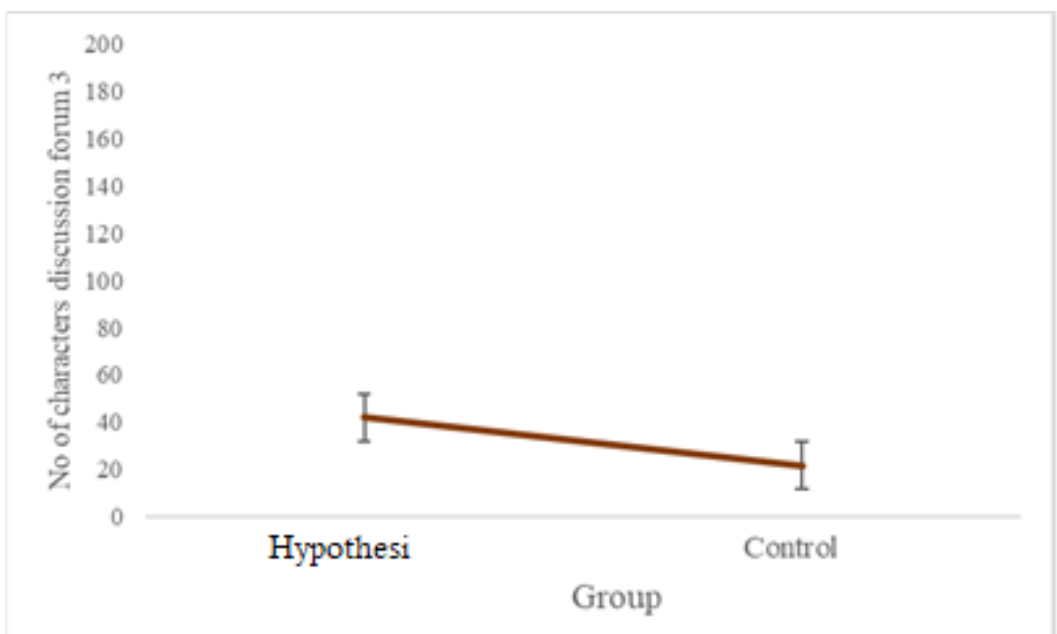

Figura 43 - Diferença entre os grupos no tamanho das postagens no fórum de discussão do módulo 3 


\title{
6.3.8
}

\section{Tamanho total das postagens nos fóruns de discussão dos módulos} 1,2 e 3

\author{
VARIÁVEL INDEPENDENTE: 〈AGRUPAME〉
}

VARIÁVEL DEPENDENTE: <CRC_MOD1>, <CRC_MOD2> e <CRC_MOD3>

\section{Descriptive Statistics}

Dependent Variable: Total amount of characters on forum
\begin{tabular}{|l|r|r|r|}
\hline Group & \multicolumn{1}{c|}{ Mean } & Std. Deviation & \multicolumn{1}{c|}{ N } \\
\hline H & 72,4038 & 277,72004 & 260 \\
C & 179,2918 & 625,11159 & 305 \\
Total & 130,1044 & 498,88567 & 565 \\
\hline
\end{tabular}

Quadro 47 - Estatisticas descritivas para o tamanho das postagens por grupo nos förum de discussão dos módulos 1.2 e 3

Tests of Between-Subjects Effects

Dependent Variable: Normal Score of CRC_TOT using Blom's Formula

\begin{tabular}{|l|r|r|r|r|r|r|}
\hline Source & \multicolumn{1}{|c|}{$\begin{array}{c}\text { Type III Sum } \\
\text { of Squares }\end{array}$} & df & Mean Square & F & \multicolumn{1}{c|}{ Sig. } & $\begin{array}{c}\text { Partial Eta } \\
\text { Squared }\end{array}$ \\
\hline Corrected Model & $1,258^{\text {a }}$ & 1 & 1,258 & 3,121 &, 078 &, 006 \\
Intercept & 2,526 & 1 & 2,526 & 6,267 &, 013 &, 011 \\
AGRUPAME & 1,258 & 1 & 1,258 & 3,121 &, 078 &, 006 \\
Error & 226,930 & 563 &, 403 & & & \\
Total & 231,024 & 565 & & & & \\
Corrected Total & 228,188 & 564 & & & & \\
\hline
\end{tabular}

a. $\mathrm{R}$ Squared $=, 006$ (Adjusted R Squared $=, 004$ )

Quadro 48 - Resultados da ANOVA para os efeitos de grupo no tamanho das postagens nos fóruns de discussão dos módulos 1, 2 e 3

Os resultados da ANOVA demonstraram que houve uma diferença marginal entre os grupos no que se refere ao tamanho total das postagens nos fóruns do curso, correspondentes ao somatório dos caracteres de todas as postagens, com $(F(1,563)=3,121, p=0,078)$. A alocação em um dos grupos explicou somente $0,6 \%$ da variância total no tamanho das postagens $\left(\eta^{2}=0,011\right) \mathrm{e}$ devido à falta de homogeneidade na distribuição $(F$ de Levene $(1,563)=23,125, p$ $=0,000)$, rodamos um Teste $\mathrm{t}$ com correção dos graus de liberdade, o que confirmou os testes anteriores indicando que o grupo de Controle produziu postagens significativamente maiores que o grupo Hipótese $(t(433,778)=2,691$, $p=0,007)$. 


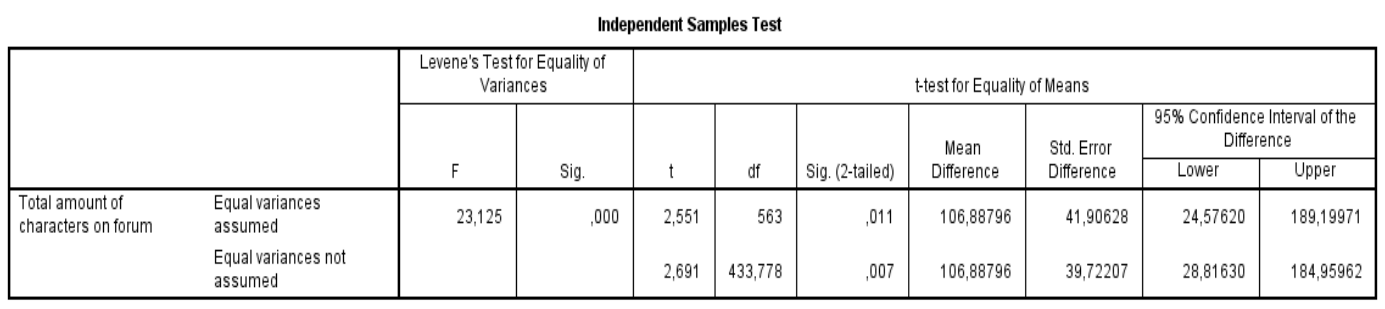

Quadro 49 - Resultados do Teste t para tamanho das postagens por grupo nos fóruns de discussão dos módulos 1, 2 e 3

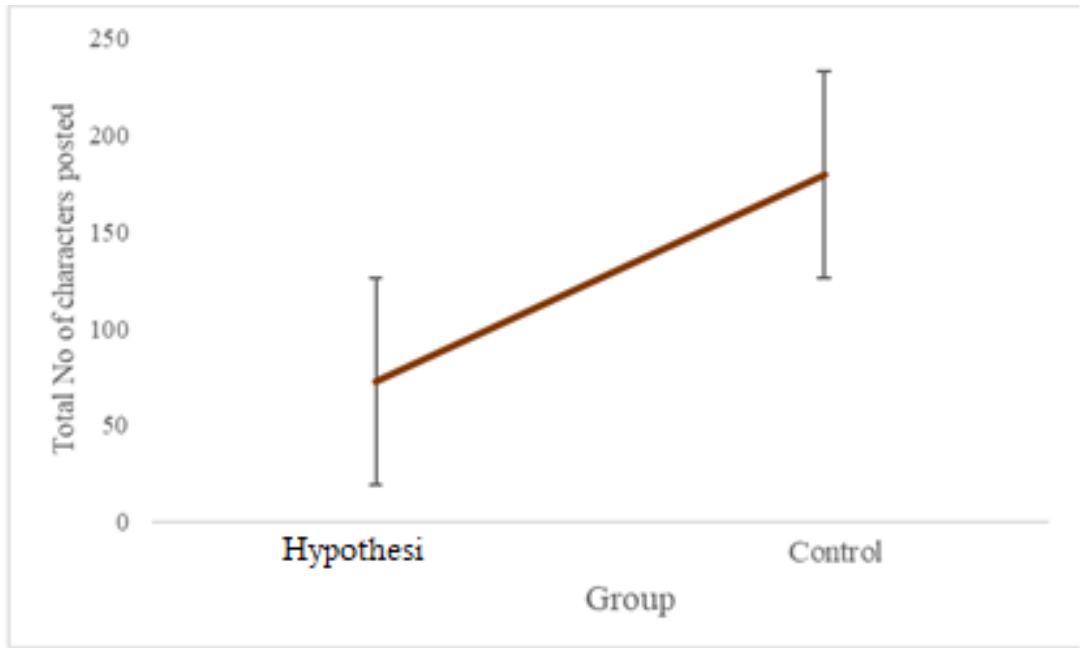

Figura 44 - Diferença entre os grupos no tamanho das postagens nos förzuns de discussão dos módulos 1,2 e 3

\subsection{9}

\section{Número total de visualizações de videoaulas do módulo 1}

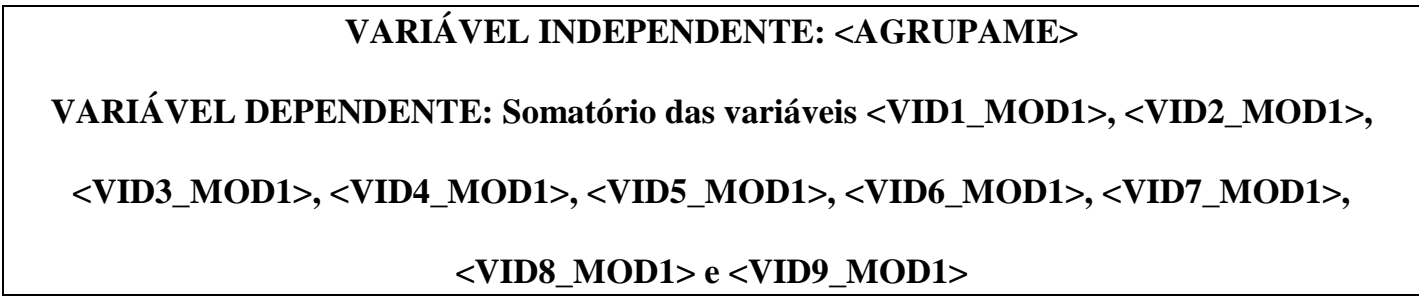

\section{Descriptive Statistics}

Dependent Variable: Video visualization Module 1
\begin{tabular}{|l|c|r|r|}
\hline Group & Mean & Std. Deviation & \multicolumn{1}{c|}{ N } \\
\hline H & 17,8462 & 13,98011 & 260 \\
C & 17,5082 & 14,60198 & 305 \\
Total & 17,6637 & 14,30755 & 565 \\
\hline
\end{tabular}

Quadro 50 - Estatísticas descritivas para quantidade de visualizações das videoaulas no Módulo I 
Tests of Between-Subjects Effects

Dependent Variable: Normal Score of Video_1 using Blom's Formula

\begin{tabular}{|l|r|r|r|r|r|r|}
\hline Source & $\begin{array}{r}\text { Type III Sum } \\
\text { of Squares }\end{array}$ & df & Mean Square & F & Sig. & $\begin{array}{c}\text { Partial Eta } \\
\text { Squared }\end{array}$ \\
\hline Corrected Model &, $061^{\mathrm{a}}$ & 1 &, 061 &, 063 &, 801 &, 000 \\
Intercept &, 037 & 1 &, 037 &, 039 &, 844 &, 000 \\
AGRUPAME &, 061 & 1 &, 061 &, 063 &, 801 &, 000 \\
Error & 539,633 & 563 &, 958 & & & \\
Total & 539,724 & 565 & & & & \\
Corrected Total & 539,694 & 564 & & & & \\
\hline
\end{tabular}

a. R Squared $=, 000$ (Adjusted R Squared $=-, 002$ )

Quadro 51 - Resultados da ANOVA para os efeitos de grupo na quantidade de visualizações das videoaulas no Módulo 1

A ANOVA demonstrou que não houve diferença significativa entre os grupos na quantidade de visualizações das videoaulas do Módulo $1(F(1,563)=$ $0,063, p=0,801)$. Neste caso as variâncias foram homogêneas ( $F$ de Levene $(1,563)=0,253, p=0,615)$, dispensando a necessidade de rodar teste adicionais para confirmação dos resultados da ANOVA.

30

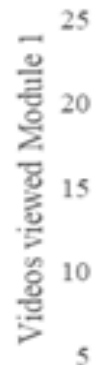

Hypothesi

Control

Group

Figura 45 - Diferença entre os grupos na quantidade de visualizações das videoaulas no Módulo I 
6.3.10

Número total de visualizações de videoaulas do módulo 2

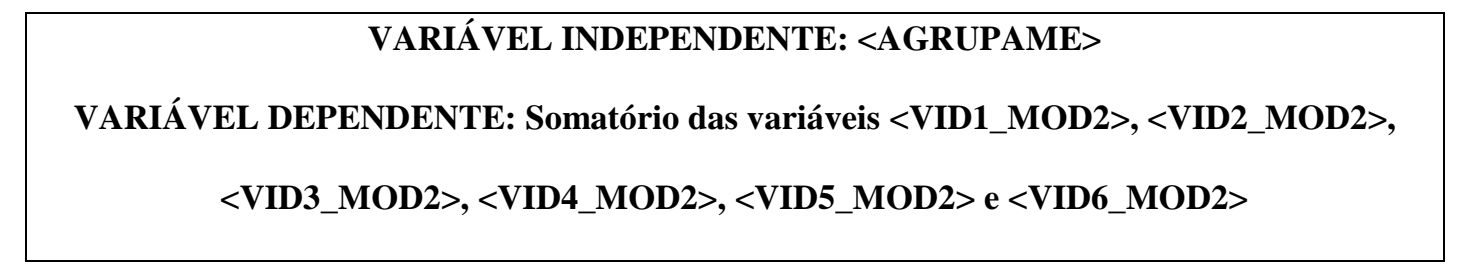

Descriptive Statistics

Dependent Variable: Video visualization Module 2

\begin{tabular}{|l|c|r|r|}
\hline Group & Mean & Std. Deviation & \multicolumn{1}{c|}{ N } \\
\hline H & 5,9808 & 6,38982 & 260 \\
C & 7,6197 & 9,97561 & 305 \\
Total & 6,8655 & 8,54730 & 565 \\
\hline
\end{tabular}

Quadro 52 - Estatísticas descritivas para quantidade de visualizações das videoaulas no Módulo 2

Tests of Between-Subjects Effects

Dependent Variable: Normal Score of Video_2 using Blom's Formula

\begin{tabular}{|l|r|r|r|r|r|r|}
\hline Source & \multicolumn{1}{|c|}{$\begin{array}{c}\text { Type III Sum } \\
\text { of Squares }\end{array}$} & df & Mean Square & F & \multicolumn{1}{c|}{ Sig. } & $\begin{array}{r}\text { Partial Eta } \\
\text { Squared }\end{array}$ \\
\hline Corrected Model & $3,504^{\mathrm{a}}$ & 1 & 3,504 & 4,413 &, 036 &, 008 \\
Intercept &, 815 & 1 &, 815 & 1,026 &, 312 &, 002 \\
AGRUPAME & 3,504 & 1 & 3,504 & 4,413 &, 036 &, 008 \\
Error & 447,048 & 563 &, 794 & & & \\
Total & 451,665 & 565 & & & & \\
Corrected Total & 450,552 & 564 & & & & \\
\hline
\end{tabular}

a. $\mathrm{R}$ Squared $=, 008$ (Adjusted R Squared $=, 006$ )

Quadro 53 - Resultados da ANOVA para os efeitos de grupo na quantidade de visualizações das videoaulas no Módulo 2

A diferença entre os grupos na quantidade de visualizações de vídeos no módulo 2 foi significativa $(F(1,563)=4,413, p=0,036)$. Mais precisamente, alunos que foram alocados no grupo de Controle tiveram mais visualizações de vídeo que os alocados no grupo Hipótese. Entretanto, a alocação de grupo explicou somente $0,8 \%$ da variância no total das visualizações de vídeo do módulo $2\left(\eta^{2}=0,009\right)$, ou seja, o efeito foi bastante modesto. Não houve necessidade de testes confirmatórios tendo em vista que a condição de homogeneidade foi atingida $(F$ de Levene $(1,563)=2,529, p=0,112)$. 


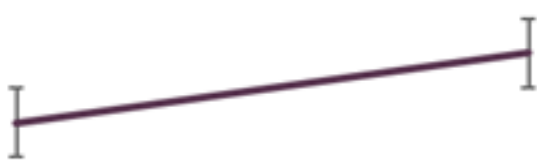

0

Hypothesi

Control

Group

Figura 46 - Diferença entre os grupos na quantidade de visualizações das videoaulas no Módulo 2

\subsubsection{1}

Número total de visualizações de videoaulas do módulo 3

VARIÁVEL INDEPENDENTE: <AGRUPAME>

VARIÁVEL DEPENDENTE: Somatório das variáveis <VID1_MOD3>, <VID2_MOD3>, <VID3_MOD3>, <VID4_MOD3>, <VID5_MOD3>, <VID6_MOD3> e <VID7_MOD3>

\section{Descriptive Statistics}

Dependent Variable: Video visualization Module 3

\begin{tabular}{|l|c|r|r|}
\hline Group & Mean & Std. Deviation & \multicolumn{1}{c|}{ N } \\
\hline H & 5,3000 & 6,71902 & 260 \\
C & 6,1574 & 8,77355 & 305 \\
Total & 5,7628 & 7,89966 & 565 \\
\hline
\end{tabular}

Quadro 54 - Estatisticas descritivas para quantidade de visualizações das videoaulas no Módulo 3

Tests of Between-Subjects Effects

Dependent Variable: Normal Score of Vldeo_3 using Blom's Formula

\begin{tabular}{|l|r|r|r|r|r|r|}
\hline Source & \multicolumn{1}{|c|}{$\begin{array}{c}\text { Type III Sum } \\
\text { of Squares }\end{array}$} & df & Mean Square & \multicolumn{1}{c|}{ F } & \multicolumn{1}{c|}{ Sig. } & \multicolumn{1}{c|}{$\begin{array}{c}\text { Partial Eta } \\
\text { Squared }\end{array}$} \\
\hline Corrected Model &, $617^{\text {a }}$ & 1 &, 617 &, 822 &, 365 &, 001 \\
Intercept & 1,540 & 1 & 1,540 & 2,051 &, 153 &, 004 \\
AGRUPAME &, 617 & 1 &, 617 &, 822 &, 365 &, 001 \\
Error & 422,728 & 563 &, 751 & & & \\
Total & 425,056 & 565 & & & & \\
Corrected Total & 423,346 & 564 & & & & \\
\hline
\end{tabular}

a. $\mathrm{R}$ Squared $=, 001$ (Adjusted R Squared $=, 000$ )

Quadro 55 - Resultados da ANOVA para os efeitos de grupo na quantidade de visualizações das videoaulas no Módulo 3 
A ANOVA demonstrou que não houve diferença significativa entre os grupos na quantidade de visualizações das videoaulas do Módulo $3(F(1,563)=$ $0,822, p=0,365)$. Neste caso as variâncias foram homogêneas ( $F$ de Levene $(1,563)=0,665, p=0,415)$, dispensando a necessidade de rodar teste adicionais para confirmação dos resultados da ANOVA.

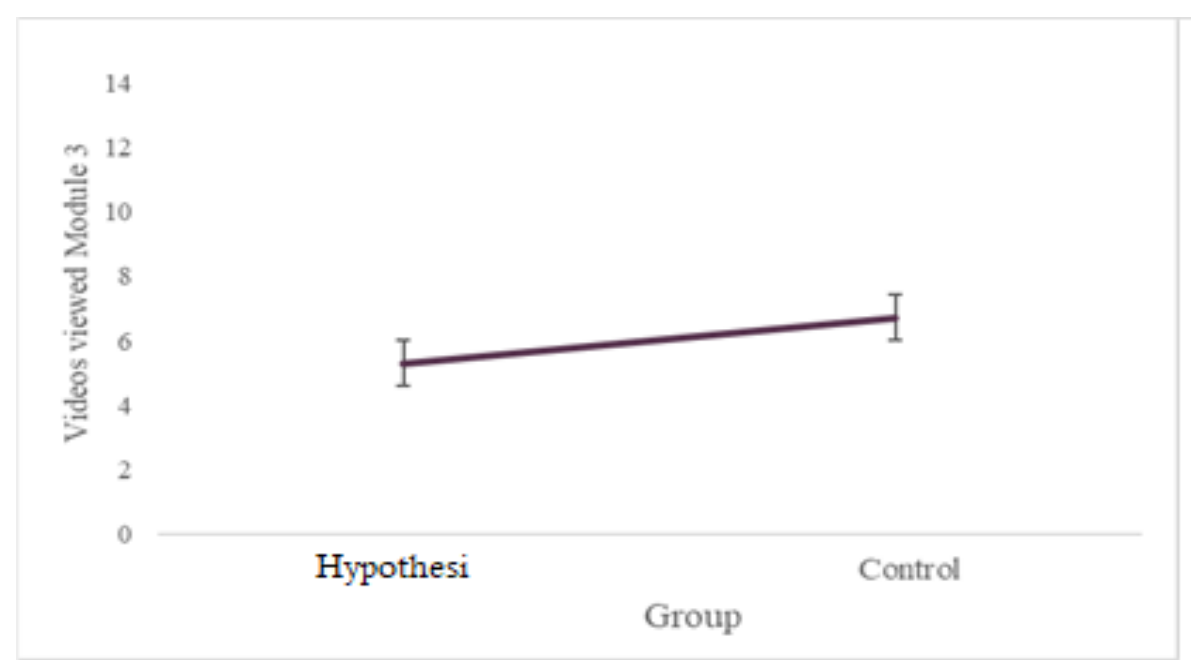

Figura 47 - Diferença entre os grupos na quantidade de visualizações das videoaulas no Módulo 3

\subsubsection{2 \\ Número total de visualizações de vídeo no curso}

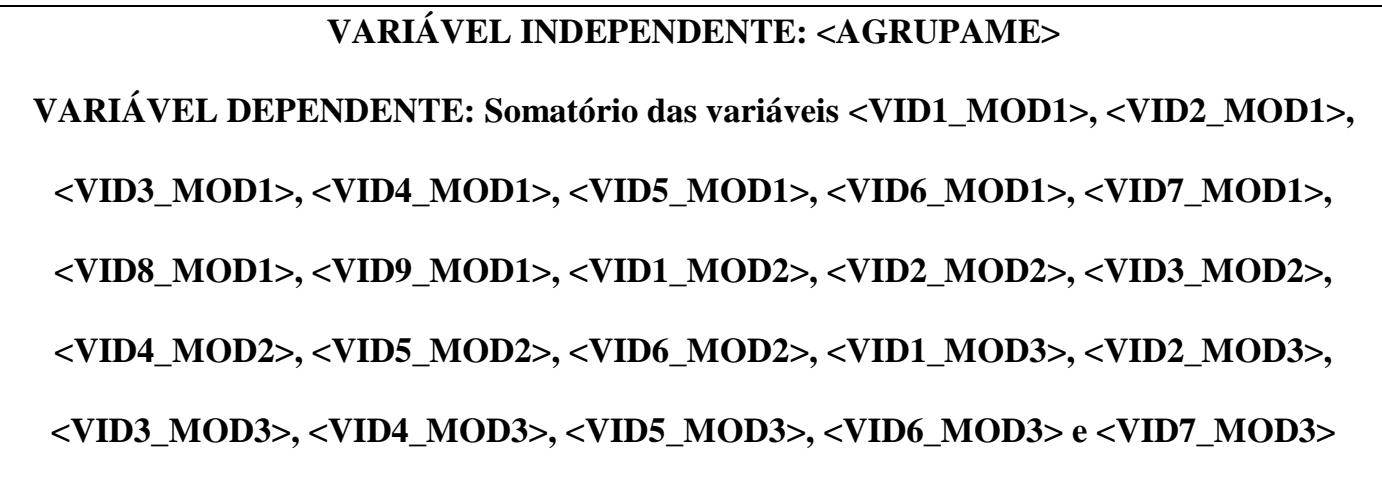

Descriptive Statistics

Dependent Variable: Total amount of videos visualized

\begin{tabular}{|l|c|r|r|}
\hline Group & Mean & Std. Deviation & \multicolumn{1}{c|}{ N } \\
\hline H & 29,1269 & 23,59052 & 260 \\
C & 31,2852 & 29,50659 & 305 \\
Total & 30,2920 & 26,94441 & 565 \\
\hline
\end{tabular}

Quadro 56 - Estatisticas descritivas para quantidade de visualizações total das videoaulas em todo curso 
Tests of Between-Subjects Effects

Dependent Variable: Normal Score of VIDEO_TOT using Blom's Formula

\begin{tabular}{|l|r|r|r|r|r|r|}
\hline Source & \multicolumn{1}{|c|}{$\begin{array}{c}\text { Type III Sum } \\
\text { of Squares }\end{array}$} & df & Mean Square & \multicolumn{1}{c|}{ F } & \multicolumn{1}{c|}{ Sig. } & \multicolumn{1}{c|}{$\begin{array}{c}\text { Sartial Eta } \\
\text { Squared }\end{array}$} \\
\hline Corrected Model &, $479^{\mathrm{a}}$ & 1 &, 479 &, 498 &, 480 &, 001 \\
Intercept &, 012 & 1 &, 012 &, 012 &, 912 &, 000 \\
AGRUPAME &, 479 & 1 &, 479 &, 498 &, 480 &, 001 \\
Error & 540,457 & 563 &, 960 & & & \\
Total & 540,962 & 565 & & & & \\
Corrected Total & 540,935 & 564 & & & & \\
\hline
\end{tabular}

a. R Squared $=, 001$ (Adjusted R Squared $=-, 001$ )

Quadro 57 - Resultados da ANOVA para os efeitos de grupo na quantidade de visualizações das videoaulas em todo curso

A Análise da Variância demonstrou que não houve diferença no total de vídeos visualizados pelos participantes do curso, ou seja, não houve efeito de grupo $(F(1,563)=0,498, p=0,480)$. Da mesma forma que nos casos anteriores onde a quantidade de visualização dos vídeos foi tomada como a variável dependente, as variâncias se mostraram homogêneas $(F$ de Levene $(1,563)=$ $0,223, p=0,637)$, dispensando assim a necessidade de análises adicionais.

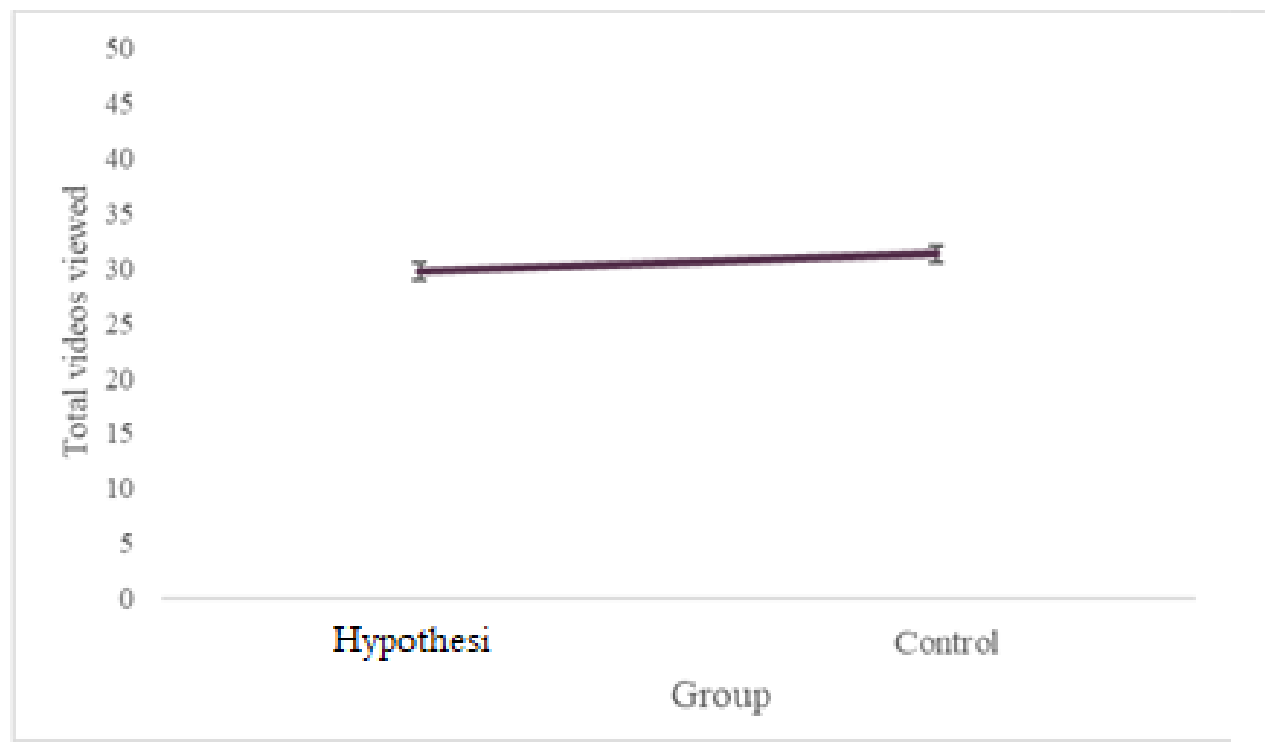

Figura 48 - Diferença entre os grupos na quantidade de visualizaçôes das videoaulas em todo curso 


\section{3 .13}

\section{Total de aprovações nos exames de avaliação}

VARIÁVEL INDEPENDENTE: <AGRUPAME>
VARIÁVEL DEPENDENTE: Somatório das variáveis de avaliação <AVL_MOD1>,
<AVL_MOD2> e <AVL_MOD3>

\section{Descriptive Statistics}

Dependent Variable: Total amount of exams passed

\begin{tabular}{|l|l|r|r|}
\hline Group & \multicolumn{1}{|c|}{ Mean } & Std. Deviation & \multicolumn{1}{c|}{$\mathrm{N}$} \\
\hline $\mathrm{H}$ & 1,3885 & 1,34102 & 260 \\
$\mathrm{C}$ & 1,5934 & 1,36158 & 305 \\
Total & 1,4991 & 1,35482 & 565 \\
\hline
\end{tabular}

Quadro 58 - Estatisticas descritivas para aprovaçz̃es nos exames de avaliação

Tests of Between-Subjects Effects

Dependent Variable: Normal Score of EXAM_TOT using Blom's Formula

\begin{tabular}{|l|r|r|r|r|r|r|}
\hline Source & \multicolumn{1}{|c|}{$\begin{array}{c}\text { Type III Sum } \\
\text { of Squares }\end{array}$} & df & Mean Square & \multicolumn{1}{c|}{ F } & \multicolumn{1}{c|}{ Sig. } & \multicolumn{1}{c|}{$\begin{array}{c}\text { Partial Eta } \\
\text { Squared }\end{array}$} \\
\hline Corrected Model & $2,024^{\text {a }}$ & 1 & 2,024 & 3,536 &, 061 &, 006 \\
Intercept &, 014 & 1 &, 014 &, 025 &, 876 &, 000 \\
AGRUPAME & 2,024 & 1 & 2,024 & 3,536 &, 061 &, 006 \\
Error & 322,256 & 563 &, 572 & & & \\
Total & 324,279 & 565 & & & & \\
Corrected Total & 324,279 & 564 & & & & \\
\hline
\end{tabular}

a. $R$ Squared $=, 006$ (Adjusted R Squared $=, 004$ )

Quadro 59 - Resultados da ANOVA para aprovações nos exames de avaliação

A análise da variância demonstrou um efeito de grupo marginalmente significante no número de aprovações nos exames do curso $(F(1,563)=3,536, p$ $=0,061)$. Alunos alocados no grupo de Controle tiveram um desempenho levemente superior em relação aos estudantes no grupo Hipótese. Entretanto, a alocação de grupo explicou somente $0,6 \%$ da variância total do número de aprovações $\left(\eta^{2}=0,006\right)$, portanto, este efeito não deveria ser considerado significativo. A homogeneidade das variâncias foi obtida $(F$ de Levene $(1,563)=$ $0,715, p=0,398)$, não demandado assim testes adicionais confirmatórios. 


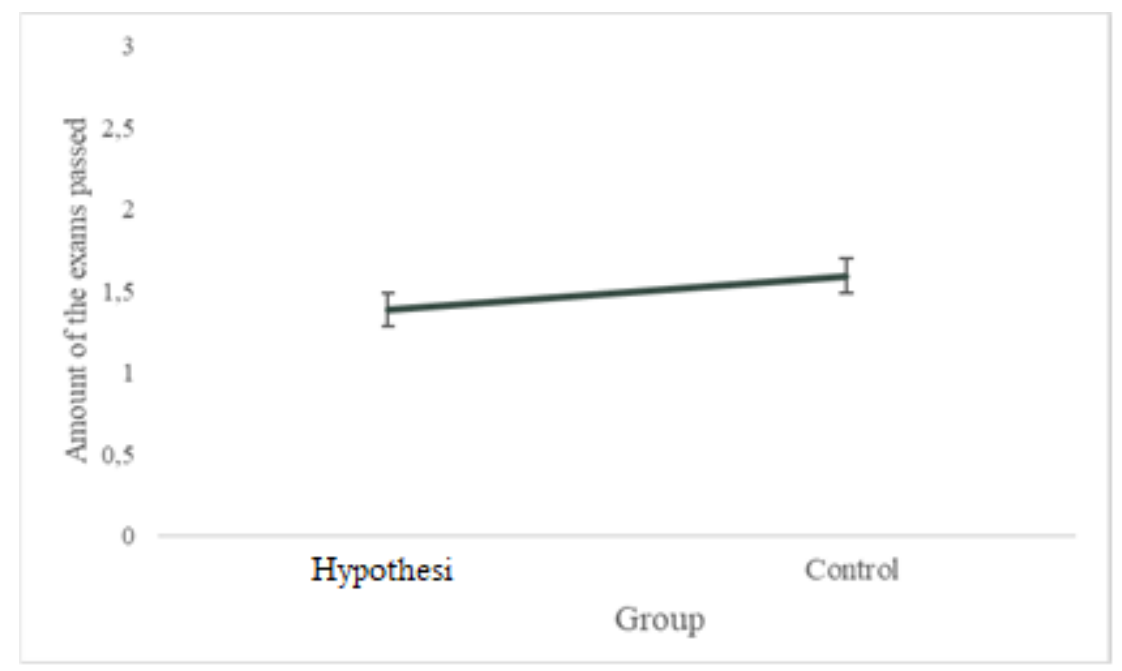

Figura 49 - Diferença entre os grupos na aprovação nos exames de avaliação

\section{4 Influência de Grupo nos exames de cada módulo}

Esta análise de contingência demonstra se houve diferenças significativas no sucesso em cada um dos exames entre o grupo com a presença do Mediador e grupo de Controle. Decidimos realizar esta segunda análise pois a anterior, baseada em ANOVA, foi aplicada somente no resultado agregado de aprovação, que incluía as três variáveis de avaliação dos exames. Nesta análise de contingência fazemos a aplicação do método para cada uma das três variáveis de avaliação, de forma independente. Para isso é feito um teste qui-quadrado da influência do grupo Hipótese e grupo de Controle, sendo ambas variáveis categóricas independentes, nos resultados dos exames de avaliação do curso (aprovação), que é uma variável categórica dependente. 


\subsection{1}

\section{Aprovação no exame de avaliação do módulo 1}

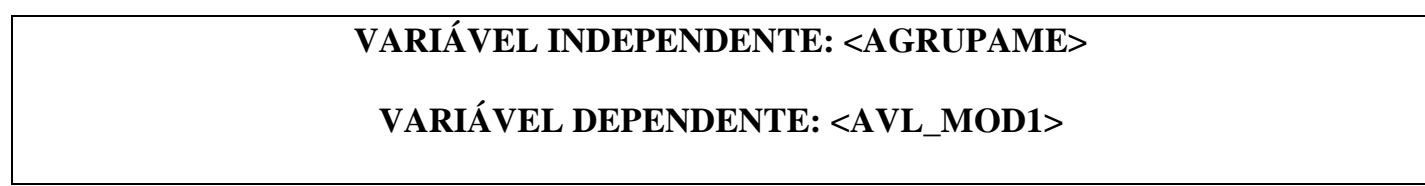

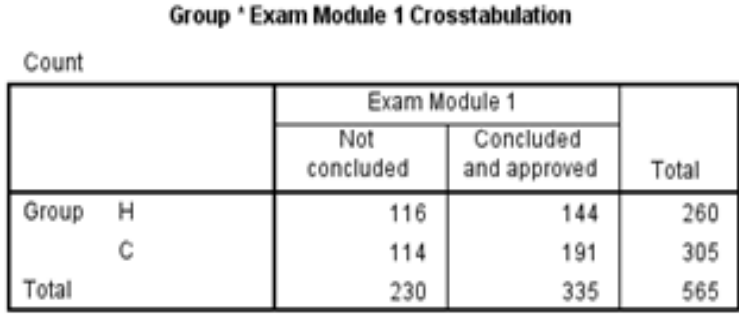

Quadro 60 - Tabela de Frequência de resultado nos exames dos gruoos na avaliacão do Módulo 1

\begin{tabular}{|l|r|r|r|}
\begin{tabular}{|ll|r|r|}
\hline \multicolumn{1}{|c|}{ Symmetric Measures } \\
\hline Nominal by Nominal & Phi & \multicolumn{1}{c|}{ Value } & Approx. Sig. \\
& Cramer's V &, 073 &, 081 \\
N of Valid Cases & & 565 &, 081 \\
\hline
\end{tabular}
\end{tabular}

Quadro 61 - Tabela de coeficientes de associação para os resultados dos grupos nos exames dos grupos na avaliação do Módulo 1

Chi-Square Tests

\begin{tabular}{|l|r|r|r|r|r|}
\hline & Value & df & \multicolumn{1}{|c|}{$\begin{array}{c}\text { Asymp. Sig. } \\
\text { (2-sided) }\end{array}$} & $\begin{array}{c}\text { Exact Sig. (2- } \\
\text { sided) }\end{array}$ & $\begin{array}{c}\text { Exact Sig. (1- } \\
\text { sided) }\end{array}$ \\
\hline Pearson Chi-Square & $3,047^{\text {a }}$ & 1 &, 081 & & \\
Continuity Correction $^{\text {b }}$ & 2,754 & 1 &, 097 & & \\
Likelihood Ratio & 3,045 & 1 &, 081 &, 086 &, 049 \\
Fisher's Exact Test & & & & & \\
Linear-by-Linear & 3,041 & 1 &, 081 & & \\
Association & 565 & & & & \\
N of Valid Cases & & & & & \\
\hline
\end{tabular}

a. 0 cells $(0,0 \%)$ have expected count less than 5 . The minimum expected count is 105,84 .

b. Computed only for a $2 \times 2$ table

Quadro 62 - Teste qui-quadrado para associação dos resultados nos exames por grupos na avaliação do Módulo 1

A análise de contingência demostrou efeito marginalmente significativo de alocação de grupo na aprovação no exame de avaliação do módulo $1(V=0,073$, $\left.\chi^{2}=3,047, p=0,081\right)$. A figura a seguir mostra que não houve diferença entre grupos no número de alunos que não concluíram o exame, mas também demonstra que houve mais alunos aprovados do grupo de Controle do que do grupo Hipótese. Como havia uma quantidade maior de estudantes no grupo de controle, é importante olhar como referência o valor baixo do coeficiente de associação de Cramer $(V)$, que é análogo ao coeficiente de correlação e indica que este efeito marginal não deveria ser considerado. 


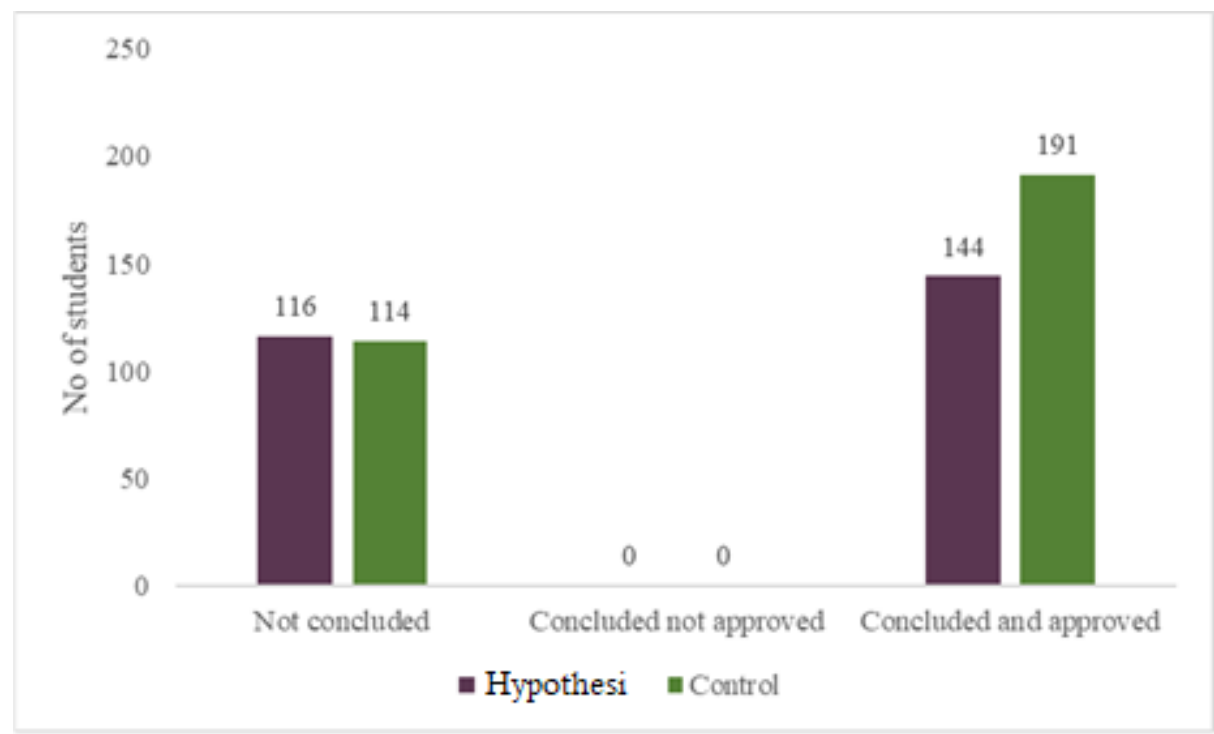

Figura 50 - Dî̉erença na frequência de resultados do exame do módulo I por grupo

\subsection{2 \\ Aprovação no exame de avaliação do módulo 2}

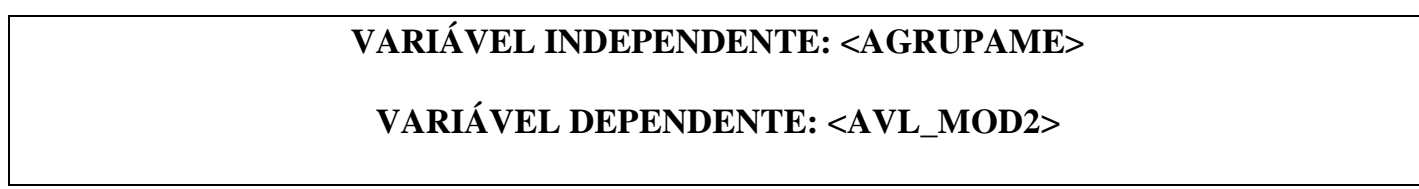

Group ' Exam Module 2 Crosstabulation

\begin{tabular}{|c|c|c|c|c|}
\hline & & \multicolumn{2}{|c|}{ Exam Module 2} & \multirow[b]{2}{*}{ Total } \\
\hline & & $\begin{array}{c}\text { Not } \\
\text { concluded }\end{array}$ & $\begin{array}{l}\text { Concluded } \\
\text { and approved }\end{array}$ & \\
\hline \multirow[t]{2}{*}{ Group } & $H$ & 137 & 123 & 260 \\
\hline & C & 144 & 161 & 305 \\
\hline Total & & 281 & 284 & 565 \\
\hline
\end{tabular}

Quadro 63 - Tabela de Frequência de resultado nos exames dos grupos na avaliação do Módulo 2
Symmetric Measures

\begin{tabular}{|ll|r|r|}
\hline & & \multicolumn{1}{|c|}{ Value } & Approx. Sig. \\
\hline Nominal by Nominal & Phi &, 055 &, 194 \\
& Cramer's V &, 055 &, 194 \\
N of Valid Cases & & 565 & \\
\hline
\end{tabular}

Quadro 64 - Tabela de coeficientes de associação para os resultados dos grupos nos exames dos grupos na avaliação do Módulo 2

Chi-Square Tests

\begin{tabular}{|c|c|c|c|c|c|}
\hline & Value & df & $\begin{array}{l}\text { Asymp. Sig. } \\
\text { (2-sided) }\end{array}$ & $\begin{array}{l}\text { Exact Sig. (2- } \\
\text { sided) }\end{array}$ & $\begin{array}{l}\text { Exact Sig. (1- } \\
\text { sided) }\end{array}$ \\
\hline Pearson Chi-Square & $1,686^{\mathrm{a}}$ & 1 &, 194 & \multirow{6}{*}{,206 } & \multirow{6}{*}{112} \\
\hline Continuity Correction ${ }^{\mathrm{b}}$ & 1,473 & 1 &, 225 & & \\
\hline Likelihood Ratio & 1,686 & 1 &, 194 & & \\
\hline Fisher's Exact Test & & & & & \\
\hline $\begin{array}{l}\text { Linear-by-Linear } \\
\text { Association }\end{array}$ & 1,683 & 1 &, 195 & & \\
\hline $\mathrm{N}$ of Valid Cases & 565 & & & & \\
\hline
\end{tabular}

a. 0 cells $(0,0 \%)$ have expected count less than 5 . The minimum expected count is 129,31 .

b. Computed only for a $2 \times 2$ table

Quadro 65 - Teste qui-quadrado para associação dos resultados nos exames por grupos na avaliação do Módulo 2 
A análise de contingência demonstrou que não houve efeito de grupo na aprovação no exame do Módulo $2\left(V=0,055, \chi^{2}=1,686, p=0,194\right)$. A figura a seguir mostra que não houve uma diferença muito pequena entre grupos no número de alunos que não concluíram o exame, mas também demonstra visualmente que houve mais alunos aprovados do grupo de Controle do que do grupo Hipótese. Como havia uma quantidade maior de estudantes no grupo de controle, é importante olhar como referência o valor baixo do coeficiente de associação de Cramer ( $V$ ) para interpretação dos resultados, que apontam efeito marginal e, por isso, não deveriam ser considerados.

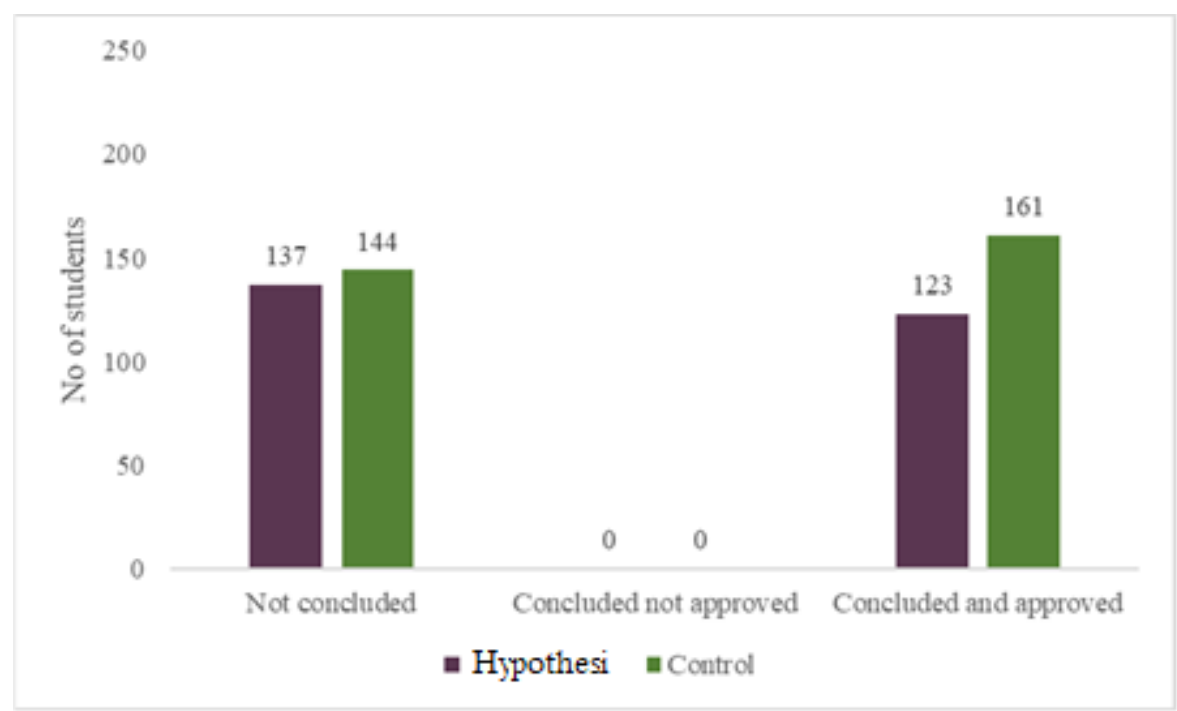

Figura 5l - Diferença na frequência de resultados do exame do módulo 2 por grupo

\subsection{3}

\section{Aprovação no exame de avaliação do módulo 3}

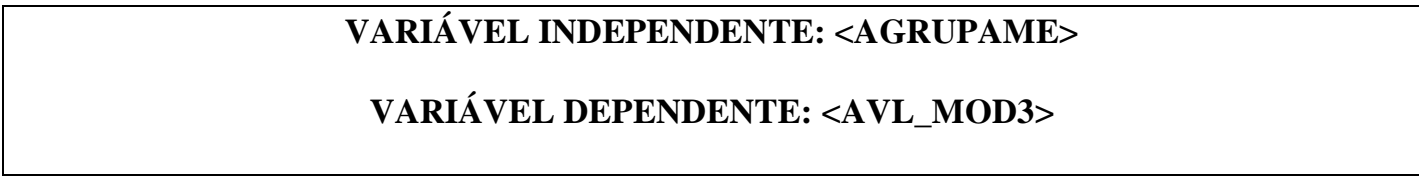

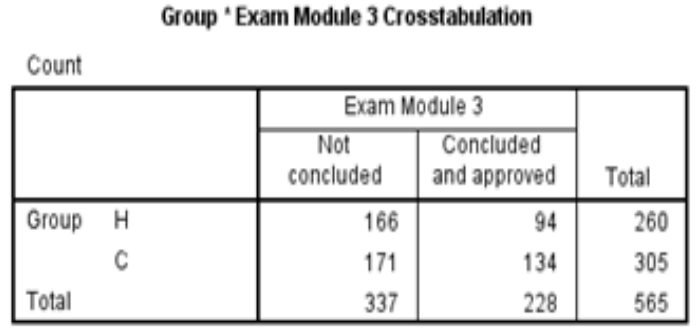

Quadro 66 - Tabela de Frequência de resultado nos exames dos grupos na avaliação do Módulo 3

\begin{tabular}{|ll|r|r|}
\hline \multicolumn{3}{|c|}{ Symmetric Measures } \\
\hline Nominal by Nominal & Phi & \multicolumn{1}{c|}{ Value } & Approx. Sig. \\
& Cramer's V &, 079 &, 060 \\
N of Valid Cases & & 5679 &, 060 \\
\hline
\end{tabular}

Quadro 67 - Tabela de coeficientes de associação para os resultados dos grupos nos exames dos grupos na avaliação do Módulo 3 
Chi-Square Tests

\begin{tabular}{|c|c|c|c|c|c|}
\hline & Value & df & $\begin{array}{l}\text { Asymp. Sig. } \\
\text { (2-sided) }\end{array}$ & $\begin{array}{l}\text { Exact Sig. (2- } \\
\text { sided) }\end{array}$ & $\begin{array}{l}\text { Exact Sig. (1- } \\
\text { sided) }\end{array}$ \\
\hline Pearson Chi-Square & $3,530^{\mathrm{a}}$ & 1 &, 060 & & \\
\hline Continuity Correction ${ }^{\text {b }}$ & 3,214 & 1 &, 073 & & \\
\hline Likelihood Ratio & 3,540 & 1 &, 060 & & \\
\hline Fisher's Exact Test & & & &, 071 &, 036 \\
\hline $\begin{array}{l}\text { Linear-by-Linear } \\
\text { Association }\end{array}$ & 3,524 & 1 &, 060 & & \\
\hline $\mathrm{N}$ of Valid Cases & 565 & & & & \\
\hline
\end{tabular}

a. 0 cells $(0,0 \%)$ have expected count less than 5 . The minimum expected count is 104,92 .

b. Computed only for a $2 \times 2$ table

Quadro 68 - Teste qui-quadrado para associação dos resultados nos exames por grupos na avaliação do Módulo 3

A análise de contingência demonstrou efeito marginal da alocação de grupo na aprovação no exame de avaliação do Módulo $3\left(V=0,079, \chi^{2}=3,530, p\right.$ $=0,06)$. De maneira análoga à análise feita para o exame do modulo 1 , o valor do coeficiente de associação foi bastante modesto, portanto, este efeito marginal não deveria ser considerado significante.

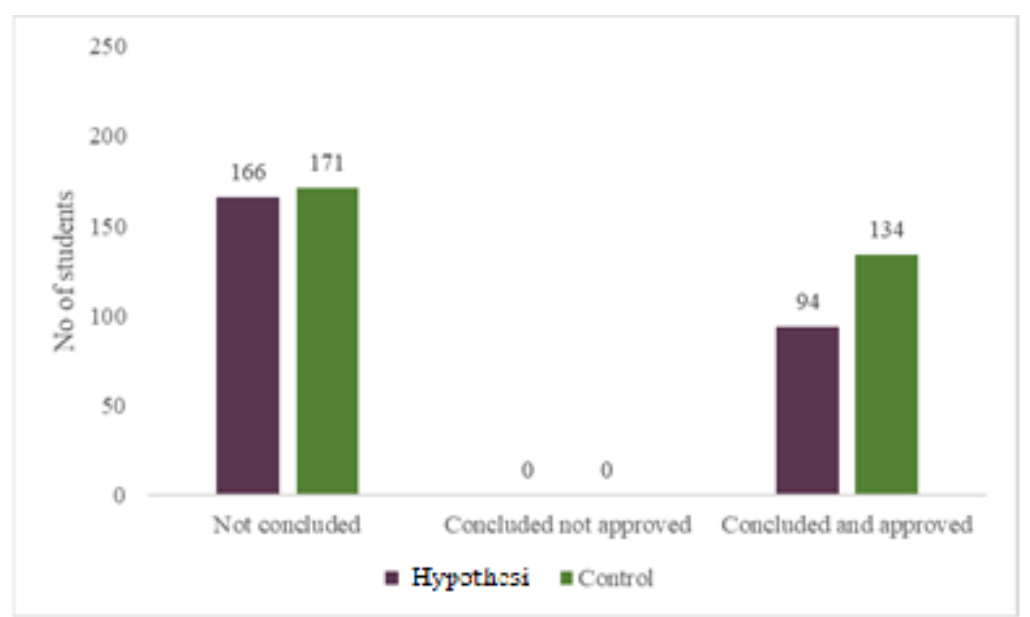

Figura 52 - Diferença na frequência de resultados do exame do módulo 3 por grupo

\section{5 \\ Verificação dos Efeitos das características demográficas nas atividades}

A seguir realizamos uma análise da variância (ANOVA) para medir a influência do sexo, grau de formação e localização geográfica regional, todas variáveis categóricas independentes, nas atividades do curso (Fóruns, videoaulas e exames). 


\subsection{1}

\section{Número total de postagens nos fóruns de discussão}

\subsubsection{1}

Sexo

VARIÁVEL INDEPENDENTE: $<$ SEX_PAR>
VARIÁVEL DEPENDENTE: Somatório das variáveis <FOR_MOD1 >, <FOR_MOD2>e
<FOR_MOD3>

\section{Descriptive Statistics}

Dependent Variable: Total amount of forum posts

\begin{tabular}{|l|r|r|r|}
\hline GENDER & \multicolumn{1}{|c|}{ Mean } & Std. Deviation & \multicolumn{1}{|c|}{ N } \\
\hline M &, 9679 & 1,25270 & 499 \\
F &, 9242 & 1,20653 & 66 \\
Total &, 9628 & 1,24643 & 565 \\
\hline
\end{tabular}

Quadro 69 - Média de postagens por sexo nos fóruns dos módulos 1, 2 e 3

Tests of Between-Subjects Effects

Dependent Variable: Normal Score of FOR_TOT using Blom's Formula

\begin{tabular}{|l|r|r|r|r|r|r|}
\hline Source & $\begin{array}{c}\text { Type III Sum } \\
\text { of Squares }\end{array}$ & df & Mean Square & F & \multicolumn{1}{c|}{ Sig. } & $\begin{array}{c}\text { Partial Eta } \\
\text { Squared }\end{array}$ \\
\hline Corrected Model &, $009^{\text {a }}$ & 1 &, 009 &, 016 &, 899 &, 000 \\
Intercept &, 262 & 1 &, 262 &, 467 &, 495 &, 001 \\
SEXO_PAR &, 009 & 1 &, 009 &, 016 &, 899 &, 000 \\
Error & 316,173 & 563 &, 562 & & & \\
Total & 317,011 & 565 & & & & \\
Corrected Total & 316,182 & 564 & & & & \\
\hline
\end{tabular}

a. $R$ Squared $=, 000$ (Adjusted R Squared $=-, 002$ )

Quadro 70 - Resultados da ANOVA para as diferenças na quantidade postagens por sexo nos fóruns de discussão para os módulos 1,2 e 3

\section{Levene's Test of Equality of Error Variances ${ }^{a}$}

Dependent Variable: Normal Score of FOR_TOT using Blom's Formule

\begin{tabular}{|c|c|c|cc|}
\hline $\mathrm{F}$ & $\mathrm{df1}$ & $\mathrm{df} 2$ & Sig. \\
\hline, 630 & 1 & 563 & &, 428 \\
\hline
\end{tabular}

Tests the null hypothesis that the error variance of the dependent variable is equal across groups.

a. Design: Intercept + SEXO_PAR

Quadro 71 - Teste de homogeneidade da variância na quantidade total de postagens nos fóruns do curso por sexo 
A análise da variância mostrou que não existe diferença significativa por sexo na quantidade total de postagens nos fóruns de discussão $(F(1,563)=0,016$, $\mathrm{p}=0,899)$. Dado que as variâncias se mostraram homogêneas ( $F$ de Levene $(1,563)=0,630, p=0,428)$, não houve a necessidade de testes confirmatórios.

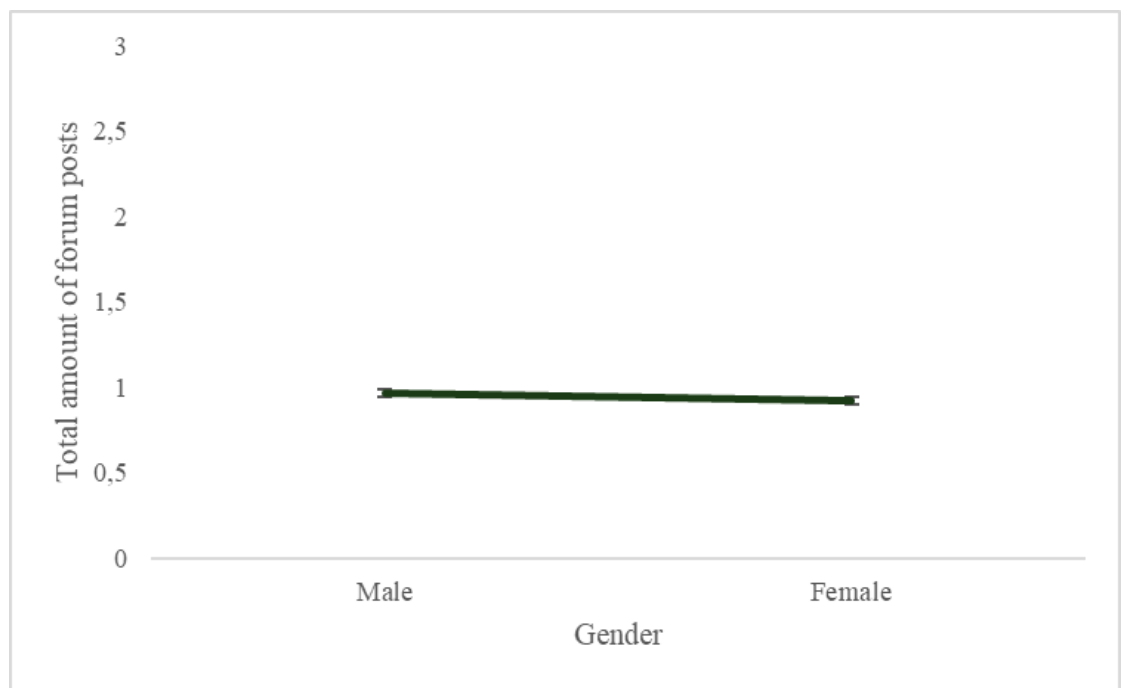

Figura 53 - Diferença na quantidade de postagens nos fóruns de discussão entre os sexos

\subsubsection{2}

\section{Grau de Formação}

VARIÁVEL INDEPENDENTE: <ENSI_SUP>
VARIÁVEL DEPENDENTE: Somatório das variáveis <FOR_MOD1>, <FOR_MOD2 > e
<FOR_MOD3>

\section{Descriptive Statistics}

Dependent Variable: Total amount of forum posts

\begin{tabular}{|l|r|r|r|}
\hline Undergraduate & \multicolumn{1}{|c|}{ Mean } & Std. Deviation & \multicolumn{1}{c|}{$\mathrm{N}$} \\
\hline High school & 1,0855 & 1,29703 & 117 \\
College &, 9306 & 1,23373 & 447 \\
Total &, 9628 & 1,24753 & 564 \\
\hline
\end{tabular}

Quadro 72 - Média de postagens nos módulos 1, 2 e 3 por grau de formação 
Tests of Between-Subjects Effects

Dependent Variable: Normal Score of FOR_TOT using Blom's Formula

\begin{tabular}{|l|r|r|r|r|r|r|}
\hline Source & \multicolumn{1}{|c|}{$\begin{array}{c}\text { Type III Sum } \\
\text { of Squares }\end{array}$} & \multicolumn{1}{c|}{ df } & Mean Square & \multicolumn{1}{c|}{ F } & \multicolumn{1}{c|}{ Sig. } & \multicolumn{1}{c|}{$\begin{array}{c}\text { Partial Eta } \\
\text { Squared }\end{array}$} \\
\hline Corrected Model &, $822^{\text {a }}$ & 1 &, 822 & 1,465 &, 227 &, 003 \\
Intercept & 1,581 & 1 & 1,581 & 2,818 &, 094 &, 005 \\
ENSI_SUP &, 822 & 1 &, 822 & 1,465 &, 227 &, 003 \\
Error & 315,261 & 562 &, 561 & & & \\
Total & 316,886 & 564 & & & & \\
Corrected Total & 316,083 & 563 & & & & \\
\hline
\end{tabular}

a. R Squared $=, 003$ (Adjusted R Squared $=, 001$ )

Quadro 73 - Resultados da ANOVA para efeito do grau de formação na quantidade de postagens nos fóruns dos Módulos 1, 2 e 3

\section{Levene's Test of Equality of Error Variances ${ }^{a}$}

Dependent Variable: Normal Score of FOR_TOT using Blom's Formu

\begin{tabular}{|c|r|r|rr|}
\hline $\mathrm{F}$ & $\mathrm{df1}$ & $\mathrm{df} 2$ & \multicolumn{2}{c|}{ Sig. } \\
\hline 1,064 & 1 & 562 & &, 303 \\
\hline
\end{tabular}

Tests the null hypothesis that the error variance of the dependent variable is equal across groups.

a. Design: Intercept + ENSI_SUP

Quadro 74 - Teste de homogeneidade da variância na quantidade total de postagens nos fóruns do curso por grau de formação

A análise da variância demonstra que não existe diferenças significativas na quantidade de postagens entre alunos do ensino superior e ensino médio ( $\mathrm{F}$ $(1,563)=1,465, \mathrm{p}=0,227)$. Dado que as variâncias foram homogêneas $(F$ de Levene $(1,562)=1,064, p=0,303)$, não houve a necessidade de testes adicionais.

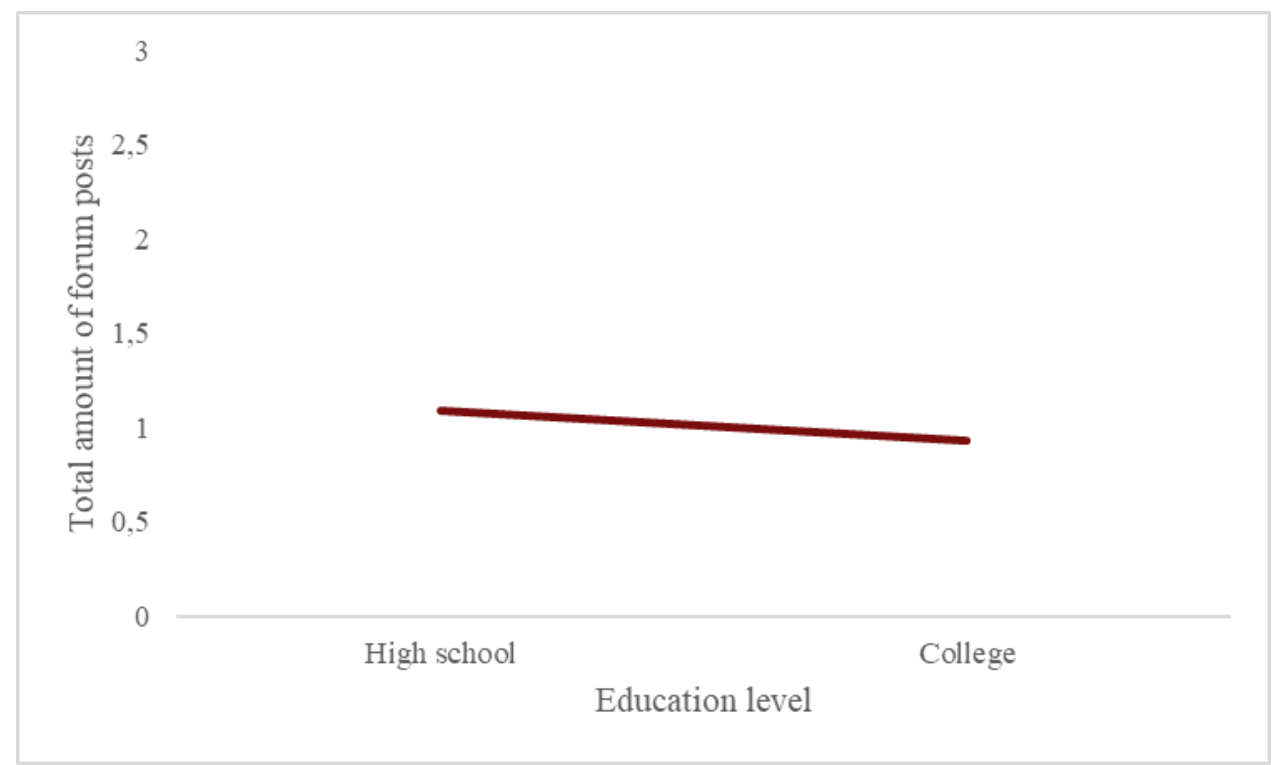

Figura 54 - Diferença na quantidade de postagens entre participantes com grau de formação superior e ensino médio 


\subsubsection{3}

\section{Localização geográfica regional}

VARIÁVEL INDEPENDENTE: <REGION>

VARIÁVEL DEPENDENTE: Somatório das variáveis <FOR_MOD1>, <FOR_MOD2> e

<FOR_MOD3>

\section{Descriptive Statistics}

Dependent Variable: Total amount of forum posts

\begin{tabular}{|l|r|r|r|}
\hline REGION & \multicolumn{1}{|c|}{ Mean } & Std. Deviation & \multicolumn{1}{|c|}{ N } \\
\hline 0 & 1,0000 & & 1 \\
Southeast &, 8904 & 1,20600 & 374 \\
Center-West & 1,3585 & 1,36007 & 53 \\
North &, 9000 & 1,28668 & 10 \\
Sul & 1,0127 & 1,33487 & 79 \\
Northeast & 1,0217 & 1,27348 & 46 \\
International & 1,0000 &, 00000 & 2 \\
Total &, 9628 & 1,24643 & 565 \\
\hline
\end{tabular}

Quadro 75 - Média de postagem nos fóruns dos Módulos 1, 2 e 3 por região geográfica

Tests of Between-Subjects Effects

Dependent Variable: Normal Score of FOR_TOT using Blom's Formula

\begin{tabular}{|l|r|r|r|r|r|r|}
\hline Source & \multicolumn{1}{|c|}{$\begin{array}{c}\text { Type III Sum } \\
\text { of Squares }\end{array}$} & df & Mean Square & F & \multicolumn{1}{c|}{ Sig. } & \multicolumn{1}{c|}{$\begin{array}{c}\text { Partial Eta } \\
\text { Squared }\end{array}$} \\
\hline Corrected Model & $3,677^{\text {a }}$ & 6 &, 613 & 1,094 &, 364 &, 012 \\
Intercept &, 703 & 1 &, 703 & 1,255 &, 263 &, 002 \\
Region & 3,677 & 6 &, 613 & 1,094 &, 364 &, 012 \\
Error & 312,505 & 558 &, 560 & & & \\
Total & 317,011 & 565 & & & & \\
Corrected Total & 316,182 & 564 & & & & \\
\hline
\end{tabular}

a. $R$ Squared $=, 012$ (Adjusted R Squared $=, 001$ )

Quadro 76 - Resultado da ANOVA para diferenças na quantidade de postagens nos fóruns dos Módulos 1, 2 e 3 por região geográfica

Levene's Test of Equality of Error Variances ${ }^{a}$

Dependent Variable: Normal Score of FOR_TOT using Blom's Formu

\begin{tabular}{|l|c|c|cc|}
\hline $\mathrm{F}$ & df1 & df2 & Sig. \\
\hline 4,054 & & 6 & 558 & \\
\hline
\end{tabular}

Tests the null hypothesis that the error variance of the dependent variable is equal across groups.

a. Design: Intercept + Region

Quadro 77 - Teste de homogeneidade da variância na quantidade total de postagens nos fóruns do curso por região 
A análise da variância mostrou que não houve diferença por região geográfica na quantidade de postagens nos fóruns de discussão do curso ( $F$ $(6,558)=1,094, p=0,364)$. Como as variâncias não eram homogêneas ( $F$ de Levene $(6,558)=4,054, p=0,001)$ e considerando a quantidade de categorias representando as regiões, rodamos um teste não paramétrico de Kruskal Wallis que confirmou o resultado anterior $\left(\chi^{2}(5)=6.344, p=0,274\right)-$ ou seja, não houve diferença entre as regiões.

\begin{tabular}{|c|c|}
\hline & $\begin{array}{l}\text { Total amount } \\
\text { of forum } \\
\text { posts }\end{array}$ \\
\hline Chi-Square & 6,344 \\
\hline df & 5 \\
\hline Asymp. Sig. &, 274 \\
\hline
\end{tabular}

a. Kruskal Wallis Test

b. Grouping Variable: REGION

Quadro 78 - Teste não paramétrico de Kruskal Wallis para diferenças entre as regiões

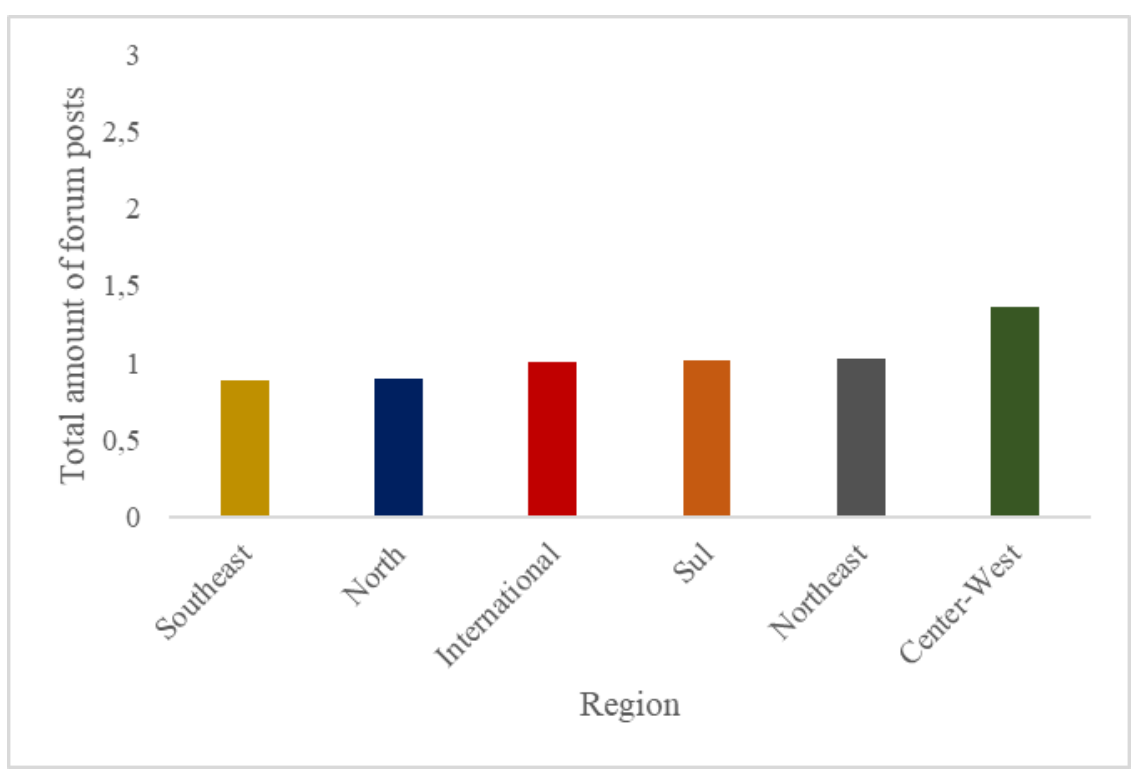

Figura 55 - Diferença na quantidade de postagens por região geográfica 


\section{5 .2}

\section{Tamanho das postagens nos fóruns, baseado no número de caracteres digitados}

\subsubsection{1}

Sexo

\begin{tabular}{c}
\hline VARIÁVEL INDEPENDENTE: $\langle$ SEX_PAR> \\
VARIÁVEL DEPENDENTE: Somatório das variáveis $\langle$ CRC_MOD1 >, <CRC_MOD2> e \\
<CRC_MOD3>
\end{tabular}

\section{Descriptive Statistics}

Dependent Variable: Total amount of characters on forum

\begin{tabular}{|l|r|r|r|}
\hline GENDER & \multicolumn{1}{|c|}{ Mean } & Std. Deviation & \multicolumn{1}{|c|}{ N } \\
\hline M & 143,9098 & 528,24178 & 499 \\
F & 25,7273 & 95,79297 & 66 \\
Total & 130,1044 & 498,88567 & 565 \\
\hline
\end{tabular}

Quadro 79 - Tamanho Médio das postagens por sexo nos fóruns dos módulos 1, 2 e 3

\section{Tests of Between-Subjects Effects}

Dependent Variable: Normal Score of CRC_TOT using Blom's Formula

\begin{tabular}{|l|r|r|r|r|r|r|}
\hline Source & \multicolumn{1}{|c|}{$\begin{array}{c}\text { Type III Sum } \\
\text { of Squares }\end{array}$} & df & Mean Square & \multicolumn{1}{c|}{ F } & \multicolumn{1}{c|}{ Sig. } & \multicolumn{1}{c|}{$\begin{array}{c}\text { Partial Eta } \\
\text { Squared }\end{array}$} \\
\hline Corrected Model & $1,071^{\text {a }}$ & 1 & 1,071 & 2,654 &, 104 &, 005 \\
Intercept &, 083 & 1 &, 083 &, 207 &, 650 &, 000 \\
SEXO_PAR & 1,071 & 1 & 1,071 & 2,654 &, 104 &, 005 \\
Error & 227,117 & 563 &, 403 & & & \\
Total & 231,024 & 565 & & & & \\
Corrected Total & 228,188 & 564 & & & & \\
\hline
\end{tabular}

a. R Squared $=, 005$ (Adjusted R Squared $=, 003$ )

Quadro 80 - Resultados da ANOVA para o tamanho das postagens por sexo nos fóruns de discussão para os módulos 1, 2 e 3

Levene's Test of Equality of Error Variances ${ }^{a}$

Dependent Variable: Normal Score of CRC_TOT using Blom's Formul;

\begin{tabular}{|c|c|c|cc|}
\hline $\mathrm{F}$ & df1 & df2 & \multicolumn{2}{|c|}{ Sig. } \\
\hline 12,563 & 1 & 563 & &, 000 \\
\hline
\end{tabular}

Tests the null hypothesis that the error variance of the dependent variable is equal across groups.

a. Design: Intercept + SEXO_PAR

Quadro 81 - Teste de homogeneidade da variância do tamanho total das postagens nos fóruns do curso por sexo 
A ANOVA demonstrou que houve diferença marginal entre os sexos com relação os tamanhos das postagens nos fóruns dos módulos 1,2 e $3(F(1,563)=$ 2,654, $p=0,104)$. Entretanto, o sexo explicou somente $0,5 \%$ da variância em número de caráteres $\left(\eta^{2}=0,005\right)$. Sendo assim, esta diferença marginal não deveria ser considerada. Como as variâncias não se mostraram homogêneas ( $F$ de Levene $(1,563)=12,563, p=0,000)$ e o tamanho dos grupos eram bem diferentes, rodamos o teste de Kruskal Wallis que é o substituto não paramétrico para a ANOVA. Este teste é utilizado quando as condições para a ANOVA não são obtidas.

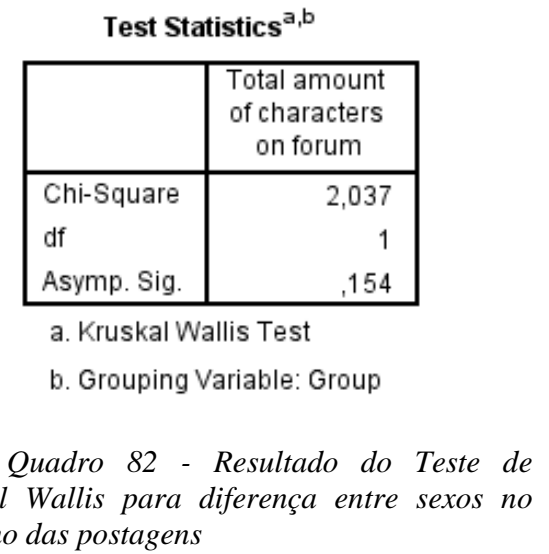

O teste de Kruskal Wallis confirmou que as diferenças de gênero não foram significativas $\left(\chi^{2}(1)=2,037, p=0,154\right)$. 


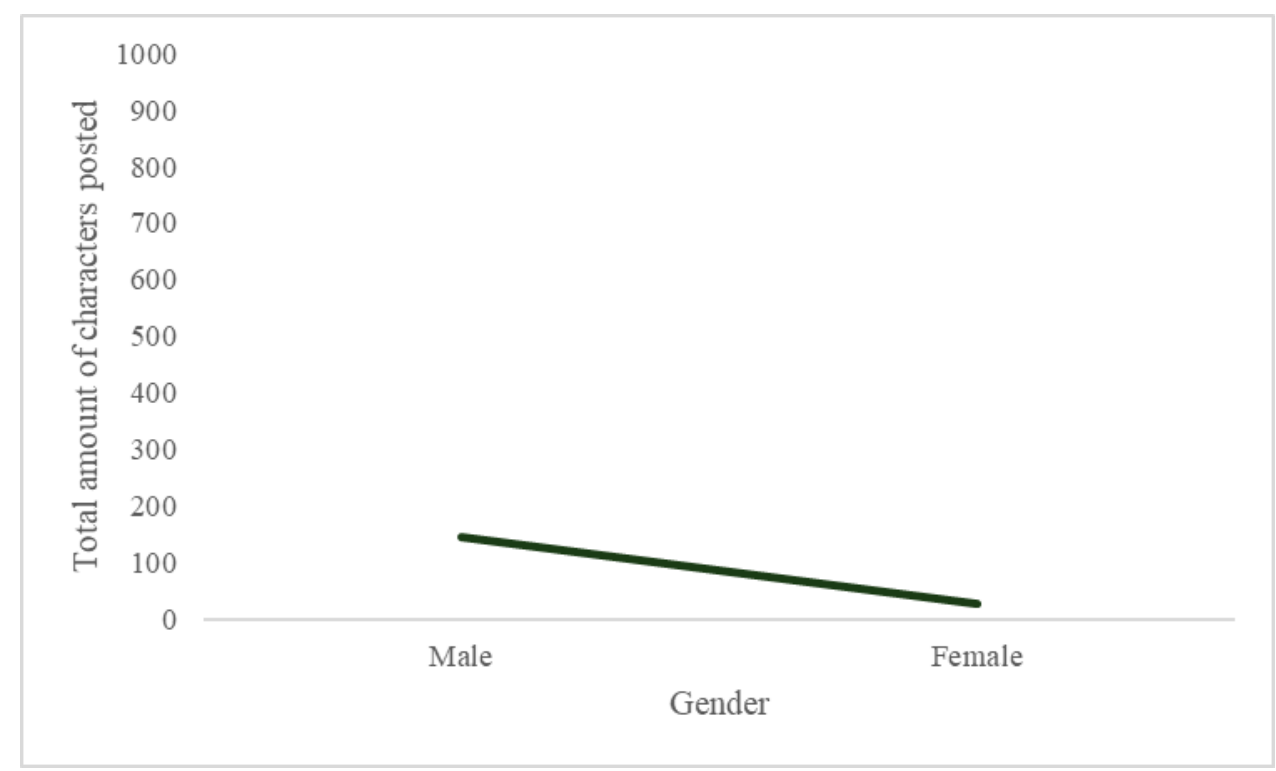

Figura 56 - Diferença entre sexos no tamanho total das postagens nos fóruns de discussão dos Módulos 1, 2 e 3

\subsubsection{2}

\section{Grau de Formação}

VARIÁVEL INDEPENDENTE: $<$ ENSI_SUP $>$
VARIÁVEL DEPENDENTE: Somatório das variáveis $\langle$ CRC_MOD1 $>,<$ CRC_MOD2 $>$ e
$<$ CRC_MOD3 $>$

\section{Descriptive Statistics}

Dependent Variable: Total amount of characters on forum

\begin{tabular}{|l|c|r|r|}
\hline Undergraduate & Mean & Std. Deviation & \multicolumn{1}{c|}{ N } \\
\hline High school & 138,0769 & 613,85415 & 117 \\
College & 128,0761 & 465,51842 & 447 \\
Total & 130,1507 & 499,32732 & 564 \\
\hline
\end{tabular}

Quadro 83 - Tamanho médio das postagens nos fóruns dos Módulos 1, 2 e 3 de acordo com o grau de formação

\section{Tests of Between-Subjects Effects}

Dependent Variable: Normal Score of CRC_TOT using Blom's Formula

\begin{tabular}{|l|r|r|r|r|r|r|}
\hline Source & \multicolumn{1}{|c|}{$\begin{array}{c}\text { Type III Sum } \\
\text { of Squares }\end{array}$} & df & Mean Square & \multicolumn{1}{c|}{ F } & \multicolumn{1}{c|}{ Sig. } & \multicolumn{1}{c|}{$\begin{array}{c}\text { Partial Eta } \\
\text { Squared }\end{array}$} \\
\hline Corrected Model &, $092^{\text {a }}$ & 1 &, 092 &, 228 &, 633 &, 000 \\
Intercept & 2,271 & 1 & 2,271 & 5,622 &, 018 &, 010 \\
ENSI_SUP &, 092 & 1 &, 092 &, 228 &, 633 &, 000 \\
Error & 227,034 & 562 &, 404 & & & \\
Total & 229,813 & 564 & & & & \\
Corrected Total & 227,126 & 563 & & & & \\
\hline
\end{tabular}

a. R Squared $=, 000$ (Adjusted R Squared $=-, 001$ )

Quadro 84 - Resultado da ANOVA para diferença entre tamanho das postagens dos alunos do ensino superior e ensino médio 
Levene's Test of Equality of Error Variances ${ }^{a}$

Dependent Variable: Normal Score of CRC_TOT using Blom's Formu

\begin{tabular}{|c|c|c|cc|}
\hline $\mathrm{F}$ & $\mathrm{df1}$ & $\mathrm{df} 2$ & \multicolumn{2}{|c|}{ Sig. } \\
\hline, 684 & 1 & 562 & &, 409 \\
\hline
\end{tabular}

Tests the null hypothesis that the error variance of the dependent variable is equal across groups.

a. Design: Intercept + ENSI_SUP

Quadro 85 - Teste de homogeneidade da variância do tamanho total das postagens nos fóruns do curso por grau de formação

A ANOVA mostra que não houve diferença significativa entre tamanho das postagens do grupo de alunos do ensino superior e o grupo de alunos com formação no ensino médio $(\mathrm{F}(1,563)=0,228, \mathrm{p}=0,633)$. Como as variâncias se mostraram homogêneas ( $F$ de Levene $=0,684, \mathrm{p}=0,409$ ), não foi necessário rodar testes adicionais comprobatórios dos resultados obtidos.

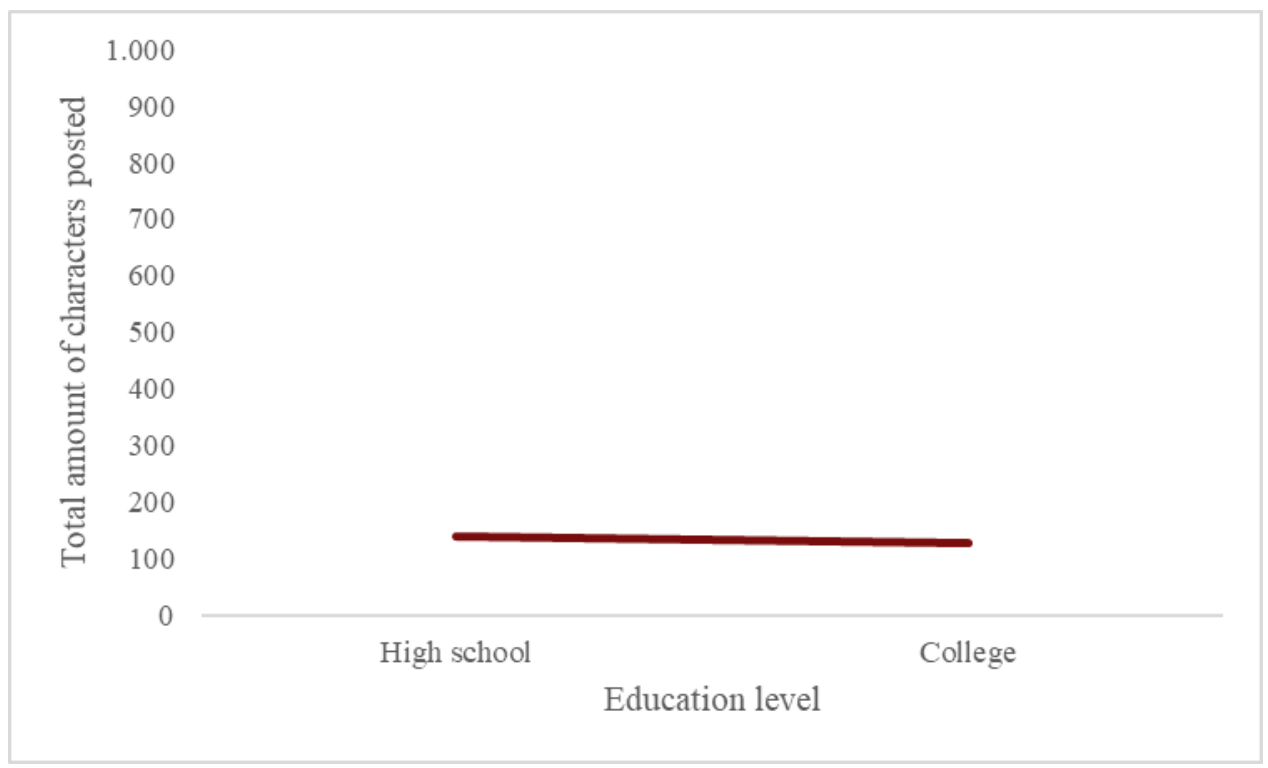

Figura 57 - Diferença no tamanho das postagens entre os alunos do ensino superior e alunos do ensino médio 


\subsubsection{3}

\section{Localização Regional}

VARIÁVEL INDEPENDENTE: <REGION>
VARIÁVEL DEPENDENTE: Somatório das variáveis <CRC_MOD1 $>,<$ CRC_MOD2 > e
<CRC_MOD3>

\section{Descriptive Statistics}

Dependent Variable: Total amount of characters on forum

\begin{tabular}{|l|r|r|r|}
\hline REGION & \multicolumn{1}{|c|}{ Mean } & Std. Deviation & \multicolumn{1}{|c|}{$\mathrm{N}$} \\
\hline 0 & 104,0000 & & 1 \\
Southeast & 120,9198 & 515,06516 & 374 \\
Center-West & 221,6604 & 563,90503 & 53 \\
North &, 0000 &, 00000 & 10 \\
Sul & 178,1266 & 515,61838 & 79 \\
Northeast & 51,3261 & 258,12504 & 46 \\
International &, 0000 &, 00000 & 2 \\
Total & 130,1044 & 498,88567 & 565 \\
\hline
\end{tabular}

Quadro 86 - Tamanho médio das postagens nos fóruns dos Módulos 1, 2 e 3 por região geográfica do participante

\section{Tests of Between-Subjects Effects}

Dependent Variable: Normal Score of CRC_TOT using Blom's Formula

\begin{tabular}{|l|r|r|r|r|r|r|}
\hline Source & \multicolumn{1}{|c|}{$\begin{array}{c}\text { Type III Sum } \\
\text { of Squares }\end{array}$} & df & Mean Square & F & \multicolumn{1}{c|}{ Sig. } & $\begin{array}{c}\text { Partial Eta } \\
\text { Squared }\end{array}$ \\
\hline Corrected Model & $4,850^{\mathrm{a}}$ & 6 &, 808 & 2,019 &, 061 &, 021 \\
Intercept &, 745 & 1 &, 745 & 1,862 &, 173 &, 003 \\
Region & 4,850 & 6 &, 808 & 2,019 &, 061 &, 021 \\
Error & 223,339 & 558 &, 400 & & & \\
Total & 231,024 & 565 & & & & \\
Corrected Total & 228,188 & 564 & & & & \\
\hline
\end{tabular}

a. R Squared $=, 021$ (Adjusted R Squared $=, 011$ )

Quadro 87 - Resultado da ANOVA para diferença entre tamanho das postagens nos fóruns por região geográfica do participante

\section{Levene's Test of Equality of Error Variances ${ }^{\mathrm{a}}$}

Dependent Variable: Normal Score of CRC_TOT using Blom's Formula

\begin{tabular}{|c|c|c|cc|}
\hline $\mathrm{F}$ & df1 & df2 & \multicolumn{2}{c|}{ Sig. } \\
\hline 6,759 & 6 & 558 & &, 000 \\
\hline
\end{tabular}

Tests the null hypothesis that the error variance of the dependent variable is equal across groups.

a. Design: Intercept + Region

Quadro 88 - Teste de homogeneidade da variância do tamanho total das postagens nos fóruns do curso por região geográfica do participante 
A ANOVA demonstra que não há diferença entre o tamanho das postagens a partir das regiões geográficas $(\mathrm{F}(6,558)=2,019, \mathrm{p}=0,061)$. Entretanto, como as variâncias não foram homogêneas $(F$ de Levene $(6,558)=6,759, p=0,000)$, também conduzimos um teste não paramétrico de Kruskal Wallis que confirmou o resultado anterior que apresentava uma diferença marginal entre as regiões $\left(\left(\chi^{2}\right.\right.$ $(5)=9,391, p=0,094)$.
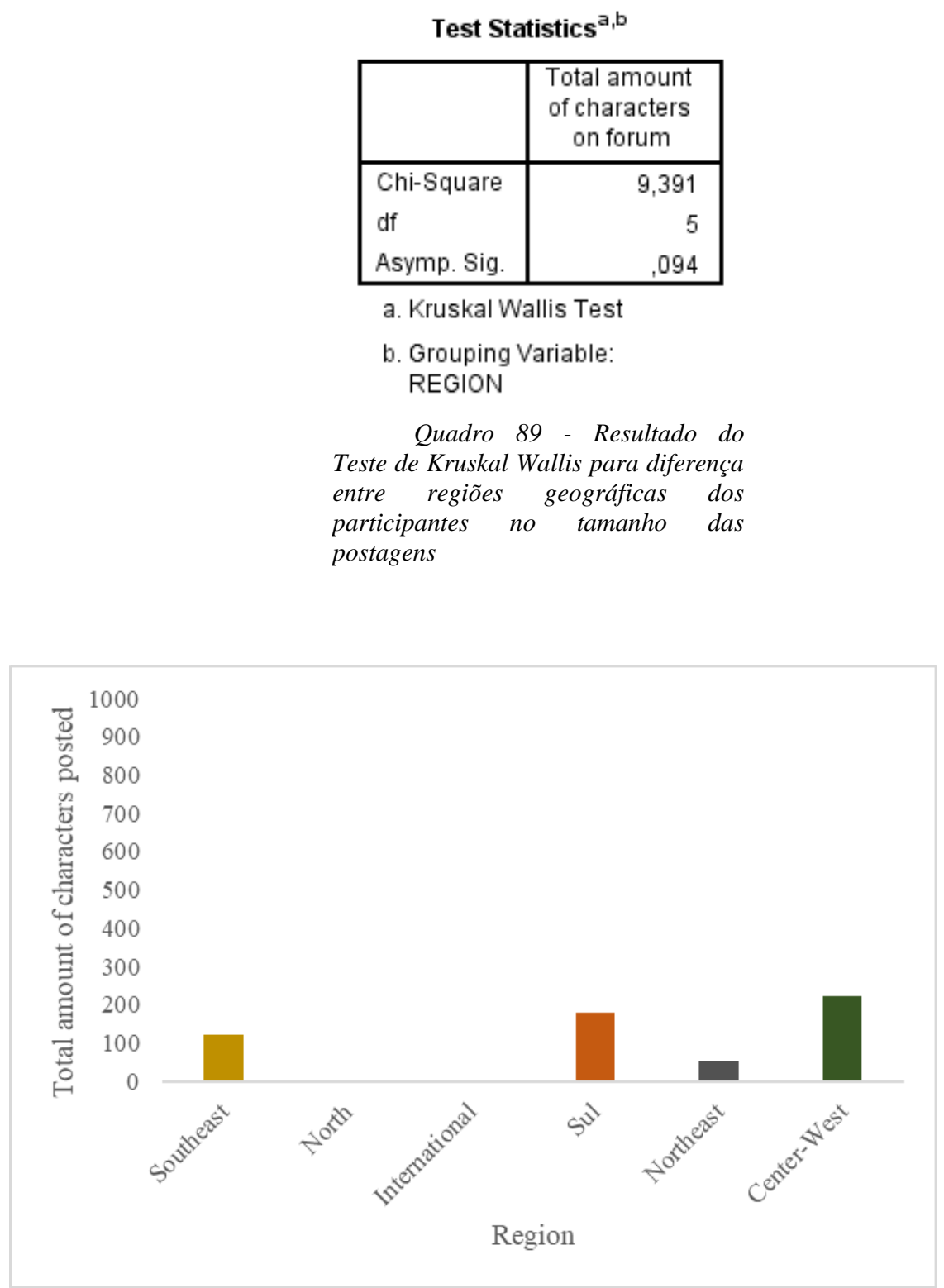

Figura 58 - Diferença no tamanho das postagens entre as regiões geográficas dos participantes do curso 


\subsection{3}

Número total de visualizações das videoaulas

\subsubsection{1}

Sexo

\begin{tabular}{|c|}
\hline VARIÁVEL INDEPENDENTE: 〈SEX_PAR> \\
\hline VARIÁVEL DEPENDENTE: Somatório das variáveis 〈VID1_MOD1〉, <VID2_MOD1〉, \\
\hline 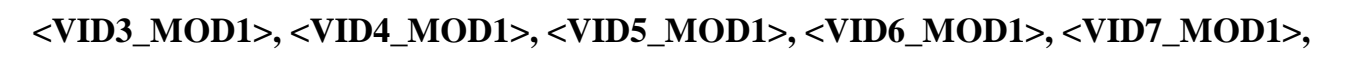 \\
\hline 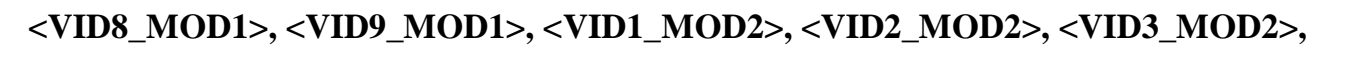 \\
\hline 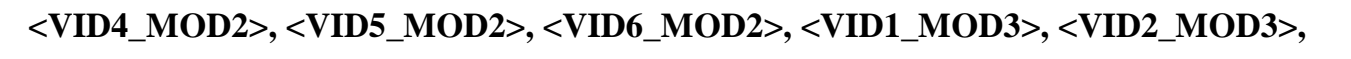 \\
\hline 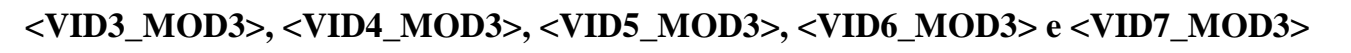 \\
\hline
\end{tabular}

Descriptive Statistics

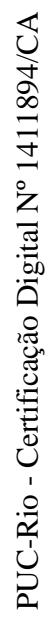

Dependent Variable: Total amount of videos visualized
\begin{tabular}{|l|c|r|r|}
\hline GENDER & Mean & Std. Deviation & N \\
\hline M & 30,7535 & 27,40228 & 499 \\
F & 26,8030 & 23,07661 & 66 \\
Total & 30,2920 & 26,94441 & 565 \\
\hline
\end{tabular}

Quadro 90 - Total de visualizações de videoaulas por sexo nos módulos 1, 2 e 3

\section{Tests of Between-Subjects Effects}

Dependent Variable: Normal Score of VIDEO_TOT using Blom's Formula

\begin{tabular}{|l|r|r|r|r|r|r|}
\hline Source & $\begin{array}{c}\text { Type III Sum } \\
\text { of Squares }\end{array}$ & df & Mean Square & F & \multicolumn{1}{c|}{ Sig. } & $\begin{array}{c}\text { Partial Eta } \\
\text { Squared }\end{array}$ \\
\hline Corrected Model &, $647^{\text {a }}$ & 1 &, 647 &, 674 &, 412 &, 001 \\
Intercept &, 261 & 1 &, 261 &, 272 &, 602 &, 000 \\
SEXO_PAR &, 647 & 1 &, 647 &, 674 &, 412 &, 001 \\
Error & 540,288 & 563 &, 960 & & & \\
Total & 540,962 & 565 & & & & \\
Corrected Total & 540,935 & 564 & & & & \\
\hline
\end{tabular}

a. R Squared $=, 001$ (Adjusted R Squared $=-, 001$ )

Quadro 91 - Resultados da ANOVA para o efeito das diferenças de sexo no total de visualizações de videoaulas nos módulos 1,2 e 3 
Levene's Test of Equality of Error Variances ${ }^{a}$

Dependent Variable: $\quad$ Normal Score of VIDEO_TOT using Blom's Formu
\begin{tabular}{|c|c|c|c|}
\hline $\mathrm{F}$ & $\mathrm{df1}$ & $\mathrm{df} 2$ & Sig. \\
\hline 006 & 1 & 563 & 941 \\
\hline
\end{tabular}

Tests the null hypothesis that the error variance of the dependent variable is equal across groups.

a. Design: Intercept + SEXO_PAR

Quadro 92 - Teste de homogeneidade da variância da quantidade de visualizações das videoaulas do curso por sexo

A análise da variância (ANOVA) demonstrou que não houve diferença entre os sexos na quantidade de visualizações das videoaulas no curso $(F(1,563)$ $=0,674, p=0,412)$. Dado que as variâncias foram homogêneas, não houve necessidade de testes adicionais confirmatórios $(F$ de Levene $(1,563)=0,006, p=$ $0,941)$.

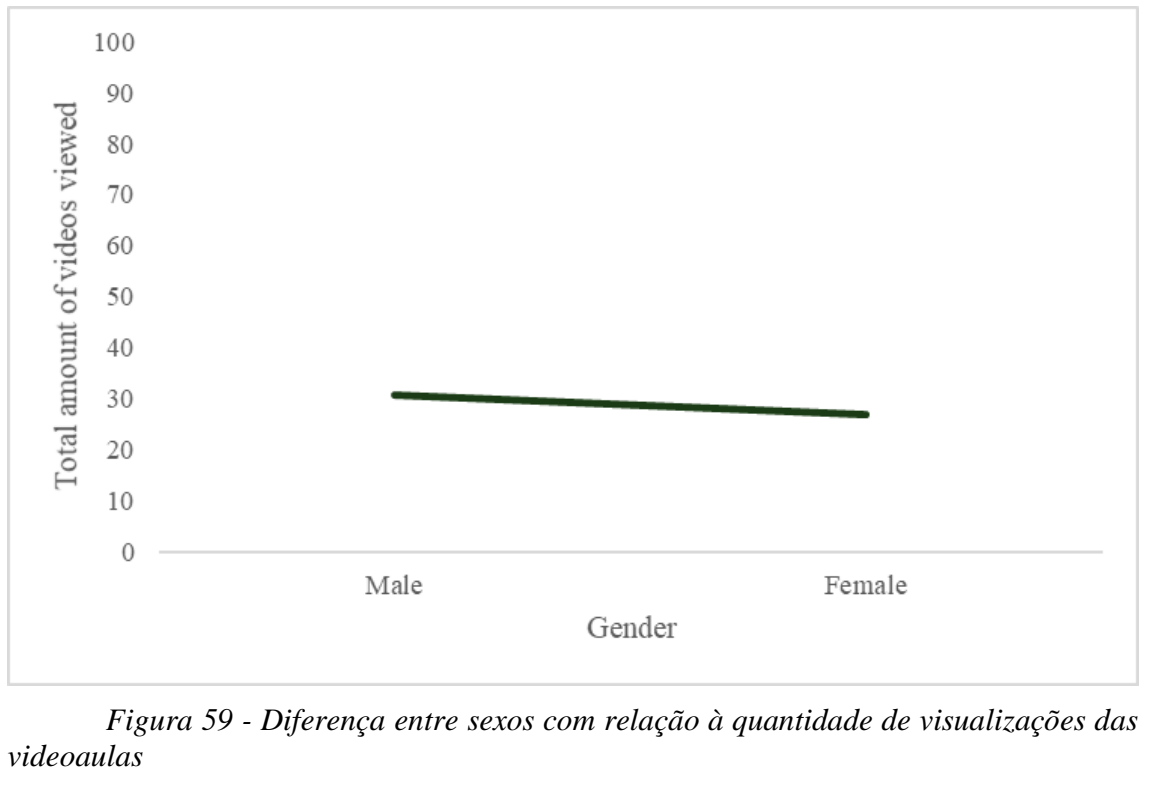

\subsubsection{2}

\section{Grau de Formação}

VARIÁVEL INDEPENDENTE: 〈ENSI_SUP>

VARIÁVEL DEPENDENTE: Somatório das variáveis <VID1_MOD1>, <VID2_MOD1>,

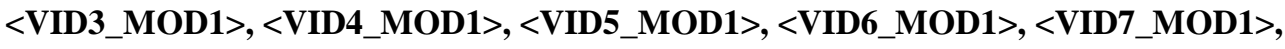

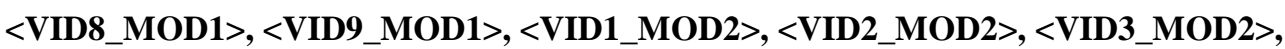

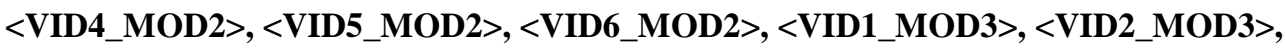
<VID3_MOD3>, <VID4_MOD3>, <VID5_MOD3>, <VID6_MOD3 > e <VID7_MOD3> 


\section{Descriptive Statistics}

Dependent Variable: Total amount of videos visualized

\begin{tabular}{|l|c|r|r|}
\hline Undergraduate & Mean & Std. Deviation & \multicolumn{1}{c|}{ N } \\
\hline High school & 35,2222 & 38,43918 & 117 \\
College & 28,8501 & 22,69455 & 447 \\
Total & 30,1720 & 26,81667 & 564 \\
\hline
\end{tabular}

Quadro 93 - Média de visualização de videoaulas dos Módulos 1, 2 e 3 por grau de formação

Tests of Between-Subjects Effects

Dependent Variable: Normal Score of VIDEO_TOT using Blom's Formula

\begin{tabular}{|l|r|r|r|r|r|r|}
\hline Source & \multicolumn{1}{|c|}{$\begin{array}{c}\text { Type III Sum } \\
\text { of Squares }\end{array}$} & df & Mean Square & \multicolumn{1}{c|}{ F } & \multicolumn{1}{c|}{ Sig. } & \multicolumn{1}{c|}{$\begin{array}{c}\text { Sartial Eta } \\
\text { Squared }\end{array}$} \\
\hline Corrected Model & $2,093^{\text {a }}$ & 1 & 2,093 & 2,202 &, 138 &, 004 \\
Intercept &, 821 & 1 &, 821 &, 863 &, 353 &, 002 \\
ENSI_SUP & 2,093 & 1 & 2,093 & 2,202 &, 138 &, 004 \\
Error & 534,184 & 562 &, 951 & & & \\
Total & 536,282 & 564 & & & & \\
Corrected Total & 536,277 & 563 & & & & \\
\hline
\end{tabular}

a. $\mathrm{R}$ Squared $=, 004$ (Adjusted R Squared $=, 002$ )

Quadro 94 - Resultados da ANOVA para diferenças por grau de formação no total de visualizações das videoaulas dos Módulos 1, 2 e 3

Levene's Test of Equality of Error Variances ${ }^{a}$

Dependent Variable: Normal Score of VIDEO_TOT using Blom's Formul

\begin{tabular}{|c|c|c|cc|}
\hline $\mathrm{F}$ & $\mathrm{df1}$ & $\mathrm{df} 2$ & \multicolumn{2}{c|}{ Sig. } \\
\hline 1,531 & 1 & 562 & &, 216 \\
\hline
\end{tabular}

Tests the null hypothesis that the error variance of the dependent variable is equal across groups.

a. Design: Intercept + ENSI_SUP

Quadro 95 - Teste de homogeneidade da variância da quantidade de visualizações das videoaulas do curso por grau de formação

A Análise da Variância (ANOVA) demonstrou que houve uma diferença pouco significativa entre os dois grupos $(\mathrm{F}(1,563)=2,202, \mathrm{p}=0,138)$, apontando que os estudantes do ensino médio visualizaram mais vezes as videoaulas se comparados aos estudantes com grau de formação superior. Entretanto, o grau de formação explica menos de $1 \%$ da variância total, podendo assim desconsiderar os efeitos deste agrupamento. Dada que as variâncias foram homogêneas ( $F$ de Levene $(1,562)=1,531, \mathrm{p}=0,216)$, não houve a necessidade de rodar testes adicionais para confirmação dos resultados. 


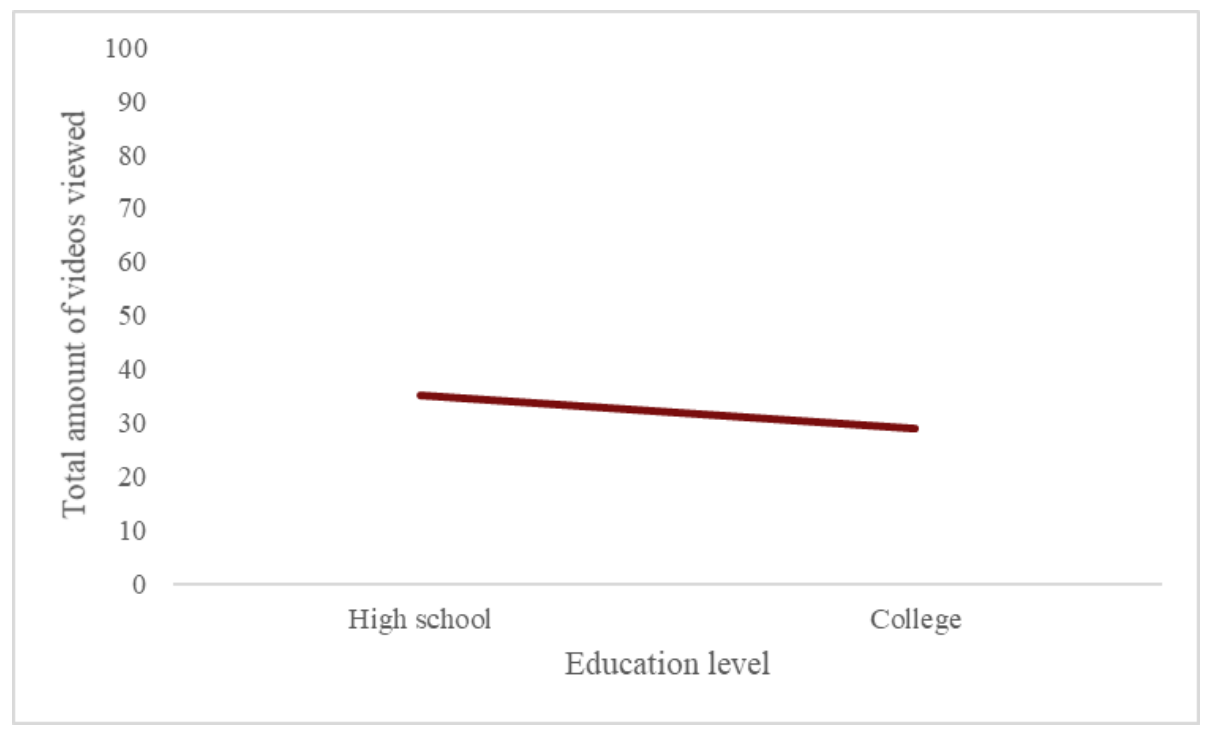

Figura 60 - Diferença na quantidade de visualizações de videoaulas por grau de formação do aluno do curso

\subsubsection{3}

\section{Localização Regional}

VARIÁVEL INDEPENDENTE: 〈REGION>

VARIÁVEL DEPENDENTE: Somatório das variáveis 〈VID1_MOD1〉, <VID2_MOD1〉,

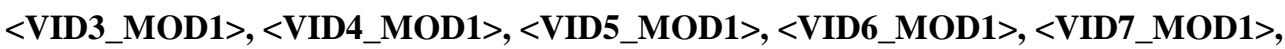

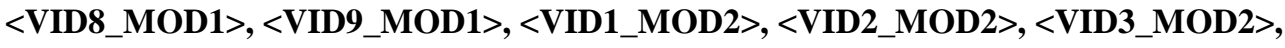

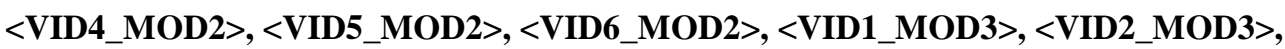
<VID3_MOD3>, <VID4_MOD3>, <VID5_MOD3>, <VID6_MOD3> e <VID7_MOD3>

Descriptive Statistics

Dependent Variable: Total amount of videos visualized

\begin{tabular}{|l|c|r|r|}
\hline REGION & Mean & Std. Deviation & \multicolumn{1}{|c|}{ N } \\
\hline 0 & 98,0000 & & 1 \\
Southeast & 31,1310 & 28,80863 & 374 \\
Center-West & 29,4151 & 19,45452 & 53 \\
North & 25,6000 & 31,61294 & 10 \\
Sul & 28,2785 & 24,67737 & 79 \\
Northeast & 26,8261 & 19,32104 & 46 \\
International & 45,5000 & 21,92031 & 2 \\
Total & 30,2920 & 26,94441 & 565 \\
\hline
\end{tabular}

Quadro 96 - Média de visualização das videoaulas dos Módulos 1, 2 e 3 por região geográfica 
Tests of Between-Subjects Effects

Dependent Variable: Normal Score of VIDEO_TOT using Blom's Formula

\begin{tabular}{|l|r|r|r|r|r|r|}
\hline Source & \multicolumn{1}{|c|}{$\begin{array}{c}\text { Type III Sum } \\
\text { of Squares }\end{array}$} & df & Mean Square & F & \multicolumn{1}{c|}{ Sig. } & $\begin{array}{r}\text { Partial Eta } \\
\text { Squared }\end{array}$ \\
\hline Corrected Model & $7,229^{\text {a }}$ & 6 & 1,205 & 1,260 &, 274 &, 013 \\
Intercept & 3,672 & 1 & 3,672 & 3,840 &, 051 &, 007 \\
Region & 7,229 & 6 & 1,205 & 1,260 &, 274 &, 013 \\
Error & 533,707 & 558 &, 956 & & & \\
Total & 540,962 & 565 & & & & \\
Corrected Total & 540,935 & 564 & & & & \\
\hline
\end{tabular}

a. $R$ Squared $=, 013$ (Adjusted $R$ Squared $=, 003$ )

Quadro 97 - Resultados das ANOVA para as diferenças na visualização total de vídeos do curso por região geográfica

Levene's Test of Equality of Error Variances ${ }^{a}$

Dependent Variable: Normal Score of VIDEO_TOT using Blom's Formul

\begin{tabular}{|c|c|c|cc|}
\hline $\mathrm{F}$ & $\mathrm{df1}$ & $\mathrm{df} 2$ & Sig. \\
\hline 1,097 & 6 & 558 & \\
\hline
\end{tabular}

Tests the null hypothesis that the error variance of the dependent variable is equal across groups.

a. Design: Intercept + Region

Quadro 98 - Teste de homogeneidade da variância da quantidade de visualizações das videoaulas do curso por região geográfica do participante

A análise demonstra que não houve diferença na visualização total de vídeos por região geográfica $(F(6,558)=1,260, p=0,274)$. Como a variância foi homogênea $(F$ de Levene $(6,558)=1,097, p=0,363)$, não houve a necessidade de testes adicionais.

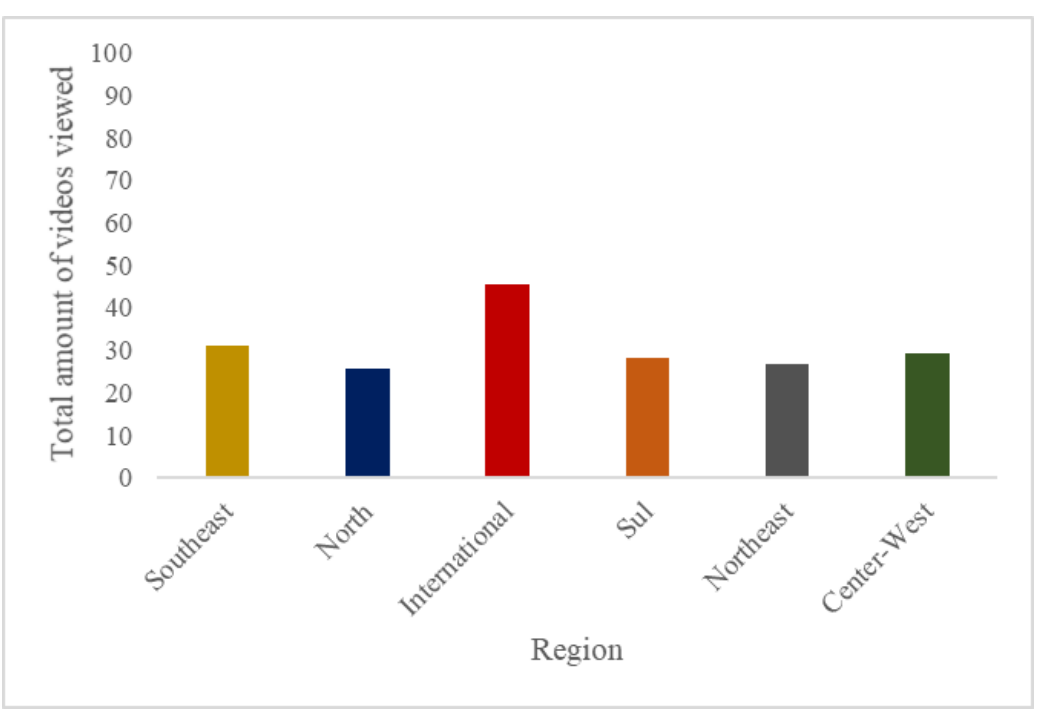

Figura 61 - Diferença visualização total por região geográfica 


\subsection{4}

\section{Número total de aprovações nos exames}

\subsubsection{1}

Sexo

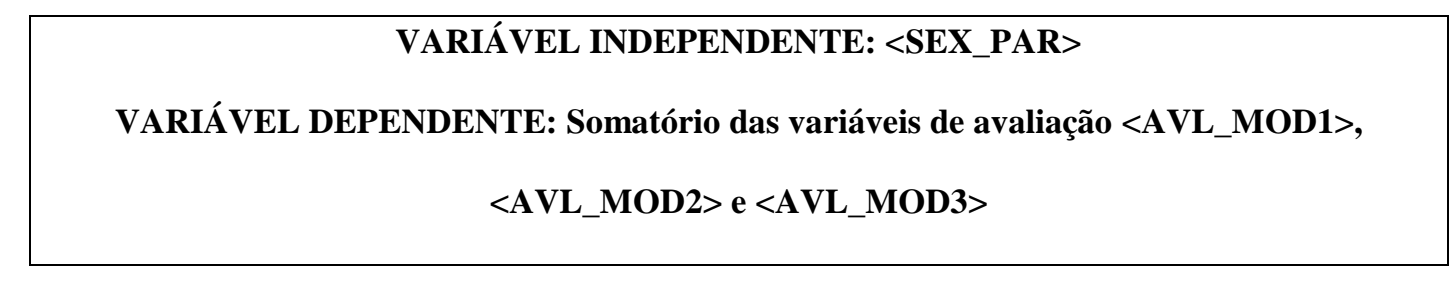

\section{Descriptive Statistics}

Dependent Variable: Total amount of exams passed

\begin{tabular}{|l|l|r|r|}
\hline GENDER & Mean & Std. Deviation & \multicolumn{1}{|c|}{ N } \\
\hline M & 1,4930 & 1,34786 & 499 \\
$\mathrm{~F}$ & 1,5455 & 1,41619 & 66 \\
Total & 1,4991 & 1,35482 & 565 \\
\hline
\end{tabular}

Quadro 99 - Média de aprovação por sexo nos exames de avaliação do curso para os Módulos 1, 2 e 3

\section{Tests of Between-Subjects Effects}

Dependent Variable: Normal Score of EXAM_TOT using Blom's Formula

\begin{tabular}{|l|r|r|r|r|r|r|}
\hline Source & \multicolumn{1}{|c|}{$\begin{array}{c}\text { Type III Sum } \\
\text { of Squares }\end{array}$} & df & Mean Square & \multicolumn{1}{c|}{ F } & \multicolumn{1}{c|}{ Sig. } & $\begin{array}{c}\text { Partial Eta } \\
\text { Squared }\end{array}$ \\
\hline Corrected Model &, $024^{\text {a }}$ & 1 &, 024 &, 042 &, 838 &, 000 \\
Intercept &, 013 & 1 &, 013 &, 023 &, 879 &, 000 \\
SEXO_PAR &, 024 & 1 &, 024 &, 042 &, 838 &, 000 \\
Error & 324,255 & 563 &, 576 & & & \\
Total & 324,279 & 565 & & & & \\
Corrected Total & 324,279 & 564 & & & & \\
\hline
\end{tabular}

a. $\mathrm{R}$ Squared $=, 000$ (Adjusted $\mathrm{R}$ Squared $=-, 002)$

Quadro 100 - Resultados da ANOVA para o efeito de sexo aprovação nos exames nos módulos 1, 2 e 3

\section{Levene's Test of Equality of Error Variances ${ }^{\text {a }}$}

Dependent Variable: Normal Score of EXAM_TOT using Blom's Formula

\begin{tabular}{|c|r|r|rr|}
\hline $\mathrm{F}$ & $\mathrm{df1}$ & $\mathrm{df} 2$ & \multicolumn{2}{c|}{ Sig. } \\
\hline 2,298 & 1 & 563 & & 130 \\
\hline
\end{tabular}

Tests the null hypothesis that the error variance of the dependent variable is equal across groups.

a. Design: Intercept + SEXO_PAR

Quadro 101 - Teste de homogeneidade da variância das aprovações nos exames de avaliação do curso por sexo 
A análise da variância demonstrou que não houve diferença significativa entre os sexos no número de aprovações nos exames de avaliação do curso ( $F$ $(1,563)=0,042, p=0,838)$. Como as variâncias se mostraram homogêneas $(F \mathrm{de}$ Levene $(1,563)=2,298, p=0,130)$, não houve necessidade de testes adicionais.

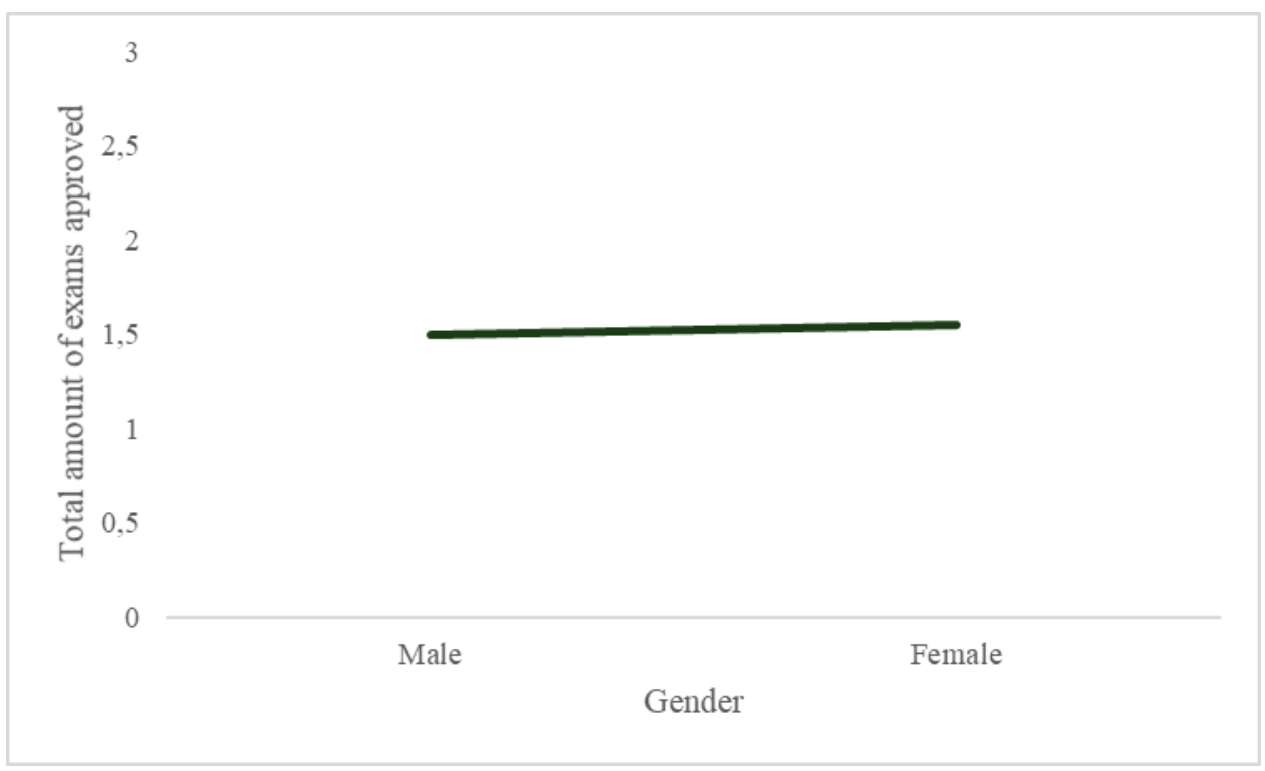

Figura 62 - Diferença entre sexos nos exames de avaliação dos Módulos 1, 2 e 3

\subsubsection{2}

\section{Grau de Formação}

\section{VARIÁVEL INDEPENDENTE: 〈ENSI_SUP>}

VARIÁVEL DEPENDENTE: Somatório das variáveis de avaliação <AVL_MOD1>,

<AVL_MOD2> e <AVL_MOD3>

\section{Descriptive Statistics}

Dependent Variable: Total amount of exams passed

\begin{tabular}{|l|l|r|r|}
\hline Undergraduate & Mean & Std. Deviation & \multicolumn{1}{c|}{$\mathrm{N}$} \\
\hline High school & 1,6239 & 1,36916 & 117 \\
College & 1,4631 & 1,35025 & 447 \\
Total & 1,4965 & 1,35455 & 564 \\
\hline
\end{tabular}

Quadro 102 - Média de aprovação nos exames de avaliação do curso por grau de formação do aluno 
Tests of Between-Subjects Effects

Dependent Variable: Normal Score of EXAM_TOT using Blom's Formula

\begin{tabular}{|l|r|r|r|r|r|r|}
\hline Source & \multicolumn{1}{|c|}{$\begin{array}{c}\text { Type III Sum } \\
\text { of Squares }\end{array}$} & df & Mean Square & \multicolumn{1}{c|}{ F } & \multicolumn{1}{c|}{ Sig. } & \multicolumn{1}{c|}{$\begin{array}{c}\text { Partial Eta } \\
\text { Squared }\end{array}$} \\
\hline Corrected Model &, $857^{\text {a }}$ & 1 &, 857 & 1,492 &, 222 &, 003 \\
Intercept &, 259 & 1 &, 259 &, 450 &, 502 &, 001 \\
ENSI_SUP &, 857 & 1 &, 857 & 1,492 &, 222 &, 003 \\
Error & 322,703 & 562 &, 574 & & & \\
Total & 323,561 & 564 & & & & \\
Corrected Total & 323,560 & 563 & & & & \\
\hline
\end{tabular}

a. $\mathrm{R}$ Squared $=, 003$ (Adjusted R Squared $=, 001$ )

Quadro 103 - Resultados da ANOVA para diferença nos resultados de avaliação do curso por grau de formação do aluno

Levene's Test of Equality of Error Variances ${ }^{a}$

Dependent Variable: Normal Score of EXAM_TOT using Blom's Formul

\begin{tabular}{|c|c|c|cr|}
\hline$F$ & df1 & df2 & Sig. & \\
\hline, 243 & 1 & 562 & & \\
\hline
\end{tabular}

Tests the null hypothesis that the error variance of the dependent

variable is equal across groups.

a. Design: Intercept + ENSI_SUP

Quadro 104 - Teste de homogeneidade da variância das aprovações nos exames de avaliação do curso por grau de formação

Descriptive Statistics

Dependent Variable: Total amount of exams passed

\begin{tabular}{|l|r|r|r|}
\hline REGION & Mean & Std. Deviation & \multicolumn{1}{|c|}{$N$} \\
\hline 0 & 3,0000 & & 1 \\
Southeast & 1,4706 & 1,34939 & 374 \\
Center-West & 1,8113 & 1,38754 & 53 \\
North & 1,3000 & 1,49443 & 10 \\
Sul & 1,4304 & 1,37453 & 79 \\
Northeast & 1,4565 & 1,31160 & 46 \\
International & 2,5000 &, 70711 & 2 \\
Total & 1,4991 & 1,35482 & 565 \\
\hline
\end{tabular}

Quadro 105 - Média de aprovações nos exames dos Módulos 1, 2 e 3 por região geográfica

A ANOVA demonstrou que não houve diferença significativa nos resultados dos exames do curso entre os dois grupos de alunos com graus de formação diferentes $(F(1,563)=1,492, p=0,222)$. Como as variâncias se mostraram homogêneas $(F$ de Levene $(1,562)=0,243, \mathrm{p}=0,622)$, não houve necessidade de testes adicionais. 


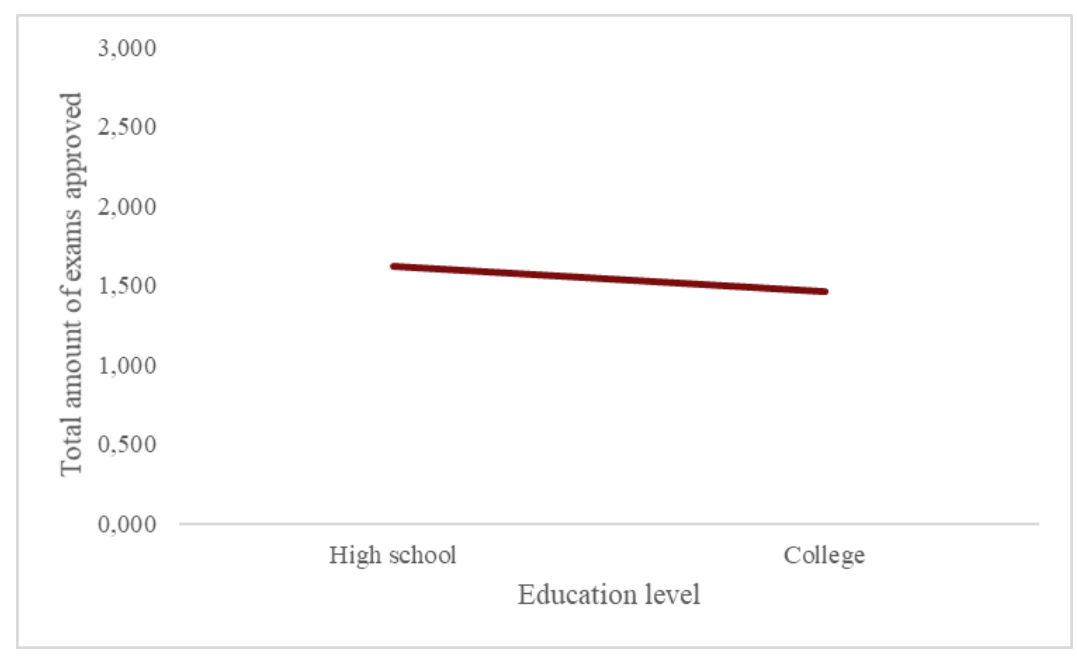

Figura 63 - Diferenças nas aprovações entre graus de formação dos alunos

\subsubsection{3}

\section{Localização Regional}

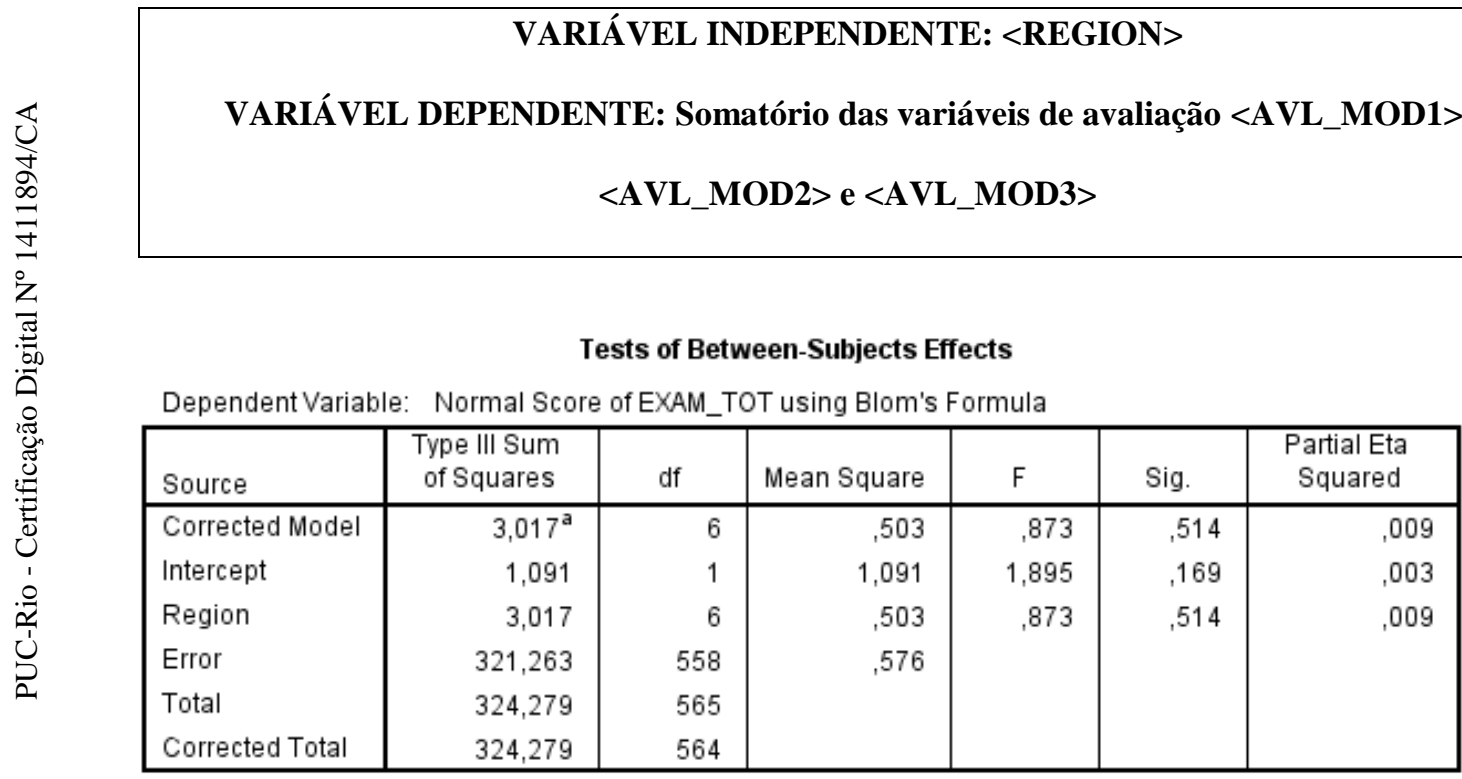

a. $R$ Squared $=, 009$ (Adjusted R Squared $=-, 001$ )

Quadro 106 - Resultados da ANOVA para diferenças de aprovação nos exames de avaliação do curso por região geográfica

Levene's Test of Equality of Error Variances ${ }^{a}$

Dependent Variable: Normal Score of EXAM_TOT using Blom's Formula

\begin{tabular}{|c|c|c|cc|}
\hline $\mathrm{F}$ & $\mathrm{df1}$ & $\mathrm{df2}$ & Sig. \\
\hline 1,737 & 6 & 558 & & 110 \\
\hline
\end{tabular}

Tests the null hypothesis that the error variance of the dependent variable is equal across groups.

a. Design: Intercept + Region

Quadro 107 - Teste de homogeneidade da variância das aprovações nos exames de avaliação do curso por região geográfica do participante 
A ANOVA demonstrou que a região geográfica do aluno do curso não tem um efeito significativo na quantidade de aprovações nos exames de avaliação do curso $(\mathrm{F}(6,558)=0,873), \mathrm{p}=0,514)$. Como as variâncias foram homogêneas $(F$ de Levene $(6,558)=1,737, p=0,110)$, não houve a necessidade de rodar testes adicionais comprobatórios.

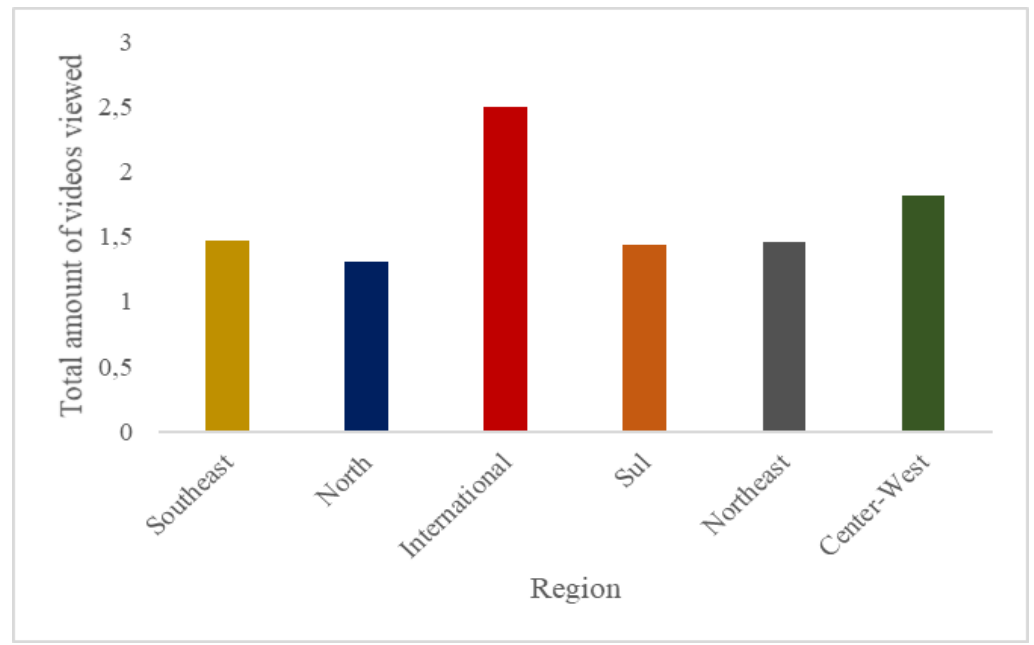

Figura 64 - Diferenças nas aprovações entre regiões geográficas dos alunos

\section{6 \\ Análise da correlação entre idade e atividades do curso}

Esta análise tem como objetivo medir a correlação entre a variável numérica contínua de idade e as variáveis numéricas ligadas às atividades do curso (postagem em fóruns de discussão, visualização das videoaulas e aprovação nos exames de avaliação do curso). Para isso realizamos uma regressão linear testando um modelo onde a variável idade funcionaria como indicador para engajamento e desempenho nas atividades do curso.

Coefficients $^{a}$

\begin{tabular}{|c|c|c|c|c|c|c|}
\hline \multirow[b]{2}{*}{ Model } & & \multicolumn{2}{|c|}{ Unstandardized Coefficients } & \multirow{2}{*}{$\begin{array}{c}\begin{array}{c}\text { Standardized } \\
\text { Coefficients }\end{array} \\
\text { Beta }\end{array}$} & \multirow[b]{2}{*}{$t$} & \multirow[b]{2}{*}{ Sig. } \\
\hline & & $\mathrm{B}$ & Std. Error & & & \\
\hline 1 & (Constant) &, 038 & 031 & & 1,219 & 223 \\
\hline & $\begin{array}{l}\text { Normal Score of Age } \\
\text { using Blom's Formula }\end{array}$ &, 067 &, 032 &, 089 & 2,130 &, 034 \\
\hline
\end{tabular}

a. Dependent Variable: Normal Score of FOR_TOT using Blom's Formula

Quadro 108 - Coeficiente Beta de Correlação entre idade e quantidade de postagens nos fóruns de discussão do curso 


\subsection{1}

\section{Número total de postagens nos fóruns de discussão}

\section{VARIÁVEL INDEPENDENTE: 〈IDADE〉}

VARIÁVEL DEPENDENTE: Somatório das variáveis <FOR_MOD1>, <FOR_MOD2> e <FOR_MOD3>

\section{Model Summary}

\begin{tabular}{|l|c|r|r|r|}
\hline Model & $\mathrm{R}$ & $\mathrm{R}$ Square & $\begin{array}{c}\text { Adjusted R } \\
\text { Square }\end{array}$ & $\begin{array}{c}\text { Std. Error of } \\
\text { the Estimate }\end{array}$ \\
\hline 1 &, $089^{\mathrm{a}}$ &, 008 &, 006 &, 7464008 \\
\hline
\end{tabular}

a. Predictors: (Constant), Normal Score of Age using Blom's Formula

Quadro 109 - Modelo de Regressão Linear simples para correção entre idade e quantidade de postagens nos fóruns do curso

ANOVA $^{\mathrm{a}}$

\begin{tabular}{|c|c|c|c|c|c|c|}
\hline & & $\begin{array}{l}\text { Sum of } \\
\text { Squares }\end{array}$ & df & Mean Square & $\mathrm{F}$ & Sig. \\
\hline \multirow[t]{3}{*}{$\overline{1}$} & Regression & 2,527 & 1 & \multirow{3}{*}{$\begin{array}{r}2,527 \\
, 557\end{array}$} & \multirow[t]{3}{*}{4,535} & \multirow[t]{3}{*}{, $034^{\mathrm{b}}$} \\
\hline & Residual & 313,655 & 563 & & & \\
\hline & Total & 316182 & 564 & & & \\
\hline
\end{tabular}

a. Dependent Variable: Normal Score of FOR_TOT using Blom's Formula

b. Predictors: (Constant), Normal Score of Age using Blom's Formula

Quadro 110 - Análise residual para medida do grau de significância de R2 no Modelo

A análise de regressão linear mostra que a variável idade correlacionou positivamente com a quantidade de postagem nos fóruns $(\beta=0,089, \mathrm{p}=0,034)$. Entretanto, a idade explicou 0,8\% das postagens nos fóruns de discussão (R2 = $0,008, F(1,563)=4,535, p=0,034)$. Portanto, apesar da correlação existente, não se pode afirmar que a variável de idade é uma boa maneira de predizer a quantidade de postagens nos fóruns de discussão do curso. 


\subsection{2}

Tamanho das postagens nos fóruns, baseado no número de caracteres digitados

\section{VARIÁVEL INDEPENDENTE: 〈IDADE〉}

VARIÁVEL DEPENDENTE: Somatório das variáveis <CRC_MOD1 $>,<$ CRC_MOD2> e <CRC_MOD3>

\section{Model Summary}

\begin{tabular}{|l|c|r|r|r|}
\hline Model & $\mathrm{R}$ & R Square & \multicolumn{1}{c|}{$\begin{array}{c}\text { Adjusted R } \\
\text { Square }\end{array}$} & $\begin{array}{c}\text { Std. Error of } \\
\text { the Estimate }\end{array}$ \\
\hline 1 &, $151^{\text {a }}$ &, 023 &, 021 &, 6293292 \\
\hline
\end{tabular}

a. Predictors: (Constant), Normal Score of Age using Blom's Formula

Quadro 111 - Modelo de Regressão Linear simples para correção entre idade e tamanho de postagens nos fóruns do curso

ANOVA $^{a}$

\begin{tabular}{|c|c|c|c|c|c|c|}
\hline \multicolumn{2}{|c|}{ Model } & $\begin{array}{l}\text { Sum of } \\
\text { Squares }\end{array}$ & df & Mean Square & $F$ & Sig. \\
\hline \multirow[t]{3}{*}{1} & Regression & 5,209 & 1 & 5,209 & 13,153 &, $000^{b}$ \\
\hline & Residual & 222,979 & 563 &, 396 & & \\
\hline & Total & 228,188 & 564 & & & \\
\hline
\end{tabular}

a. Dependent Variable: Normal Score of CRC_TOT using Blom's Formula

b. Predictors: (Constant), Normal Score of Age using Blom's Formula

Quadro 112 - Análise residual para medida do grau de significância de R2 no Modelo

Coefficients $^{\mathrm{a}}$

\begin{tabular}{|c|c|c|c|c|c|c|}
\hline \multirow[b]{2}{*}{ Mode } & & \multicolumn{2}{|c|}{ Unstandardized Coefficients } & \multirow{2}{*}{$\begin{array}{c}\text { Standardized } \\
\text { Coefficients } \\
\text { Beta } \\
\end{array}$} & \multirow[b]{2}{*}{$\mathrm{t}$} & \multirow[b]{2}{*}{ Sig. } \\
\hline & & $\mathrm{B}$ & Std. Error & & & \\
\hline \multirow[t]{2}{*}{1} & (Constant) & 071 & 026 & & 2,674 &, 008 \\
\hline & $\begin{array}{l}\text { Normal Score of Age } \\
\text { using Blom's Formula }\end{array}$ &, 097 &, 027 &, 151 & 3,627 &, 000 \\
\hline
\end{tabular}

a. Dependent Variable: Normal Score of CRC_TOT using Blom's Formula

Quadro 113 - Coeficiente Beta de Correlação entre idade e o tamanho das postagens nos fóruns de discussão do curso 
A análise de regressão linear mostra que a variável idade correlacionou positivamente com o tamanho das postagens nos fóruns $(\beta=0,151, p=0,000)$. Entretanto, a idade explicou somente $2,3 \%$ da variância no tamanho das postagens $(\mathrm{R} 2=0,023, \mathrm{~F}(1,563)=13,153, \mathrm{p}=0,000)$. Portanto, apesar da correlação existente, não se pode afirmar que a variável de idade é uma boa maneira de predizer o tamanho das postagens nos fóruns de discussão do curso.

\subsection{3}

\section{Número total de visualizações das videoaulas}

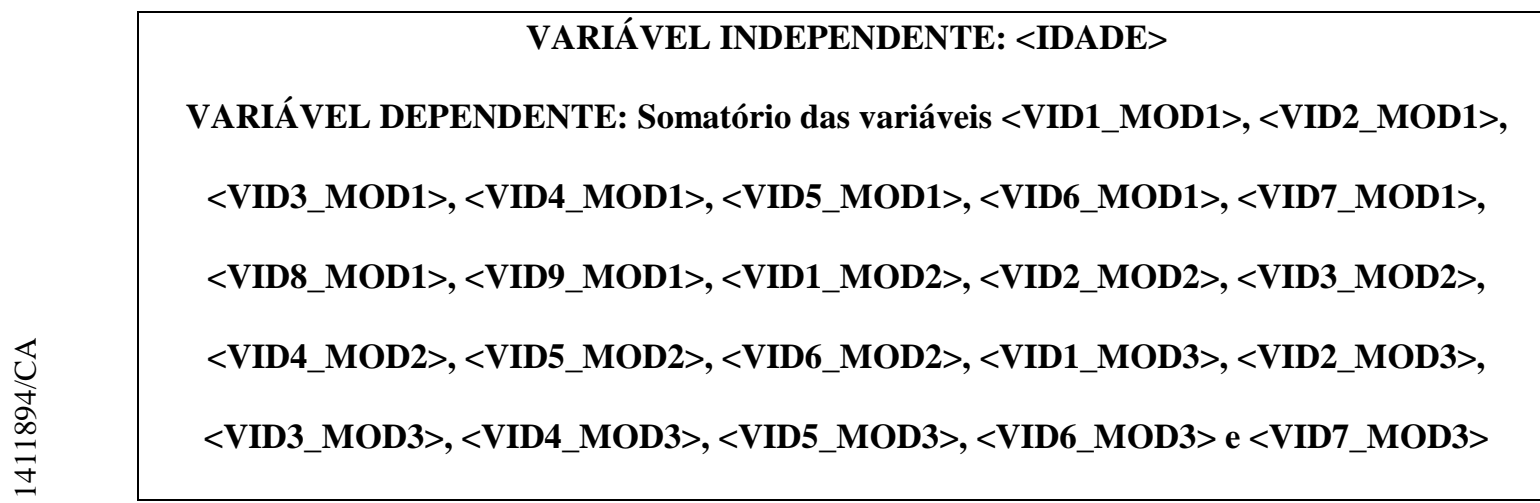

\begin{tabular}{|c|c|c|c|c|}
\hline \multicolumn{5}{|c|}{ Model Summary } \\
\hline Model & $\mathrm{R}$ & R Square & $\begin{array}{c}\text { Adjusted R } \\
\text { Square }\end{array}$ & $\begin{array}{l}\text { Std. Error of } \\
\text { the Estimate }\end{array}$ \\
\hline 1 & $135^{\mathrm{a}}$ & ,018 &, 016 & 9712544 \\
\hline
\end{tabular}

a. Predictors: (Constant), Normal Score of Age using Blom's Formula

Quadro 114 - Modelo de Regressão Linear simples para correção entre idade a quantidade de visualizações das videoaulas do curso

ANOVA $^{\text {a }}$

\begin{tabular}{|c|c|c|c|c|c|c|}
\hline & & $\begin{array}{c}\text { Sum of } \\
\text { Squares }\end{array}$ & df & Mean Square & $\mathrm{F}$ & Sig. \\
\hline \multirow[t]{3}{*}{1} & Regression & 9,838 & 1 & 9,838 & 10,429 &, $001^{\mathrm{b}}$ \\
\hline & Residual & 531,098 & 563 &, 943 & & \\
\hline & Total & 540,935 & 564 & & & \\
\hline
\end{tabular}

a. Dependent Variable: Normal Score of VIDEO_TOT using Blom's Formula

b. Predictors: (Constant), Normal Score of Age using Blom's Formula

Quadro 115 - Análise residual para medida do grau de significância de R2 no Modelo 
Coefficients $^{a}$

\begin{tabular}{|c|c|c|c|c|c|c|}
\hline \multirow[b]{2}{*}{ Mode } & & \multicolumn{2}{|c|}{ Unstandardized Coefficients } & \multirow{2}{*}{$\begin{array}{c}\begin{array}{c}\text { Standardized } \\
\text { Coefficients }\end{array} \\
\text { Beta }\end{array}$} & \multirow[b]{2}{*}{$t$} & \multirow[b]{2}{*}{ Sig. } \\
\hline & & $\mathrm{B}$ & Std. Error & & & \\
\hline \multirow[t]{2}{*}{1} & (Constant) &, 007 & 041 & & .167 & 867 \\
\hline & $\begin{array}{l}\text { Normal Score of Age } \\
\text { using Blom's Formula }\end{array}$ &, 133 &, 041 &, 135 & 3,229 &, 001 \\
\hline
\end{tabular}

a. Dependent Variable: Normal Score of VIDEO_TOT using Blom's Formula

Quadro 116 - Coeficiente Beta de Correlação entre idade e quantidade de visualizações das videoaulas do curso

A análise de regressão linear mostra que a variável idade correlacionou positivamente com quantidade de visualizações das videoaulas do curso $(\beta=$ $0,135, \mathrm{p}=0,001)$. Entretanto, a idade explicou somente $1,8 \%$ da variância $(\mathrm{R} 2=$ 0,018, F (1,563) = 10,429, p = 0,001), sendo assim, apesar da correlação existente, não se pode afirmar que a variável de idade é uma boa maneira de predizer a quantidade de visualizações de vídeos no curso. 


\subsection{4}

Número total de aprovações nos exames

VARIÁVEL INDEPENDENTE: <IDADE>
VARIÁVEL DEPENDENTE: Somatório das variáveis <AVL_MOD1 >, <AVL_MOD2> e
<AVL_MOD3>

Model Summary

\begin{tabular}{|l|c|r|r|r|}
\hline Model & $\mathrm{R}$ & $\mathrm{R}$ Square & $\begin{array}{c}\text { Adjusted R } \\
\text { Square }\end{array}$ & $\begin{array}{c}\text { Std. Error of } \\
\text { the Estimate }\end{array}$ \\
\hline 1 &, $061^{\mathrm{a}}$ &, 004 &, 002 &, 7575043 \\
\hline
\end{tabular}

a. Predictors: (Constant), Normal Score of Age using Blom's Formula

Quadro 117 - Modelo de Regressão Linear simples para correção entre idade e aprovações nos exames de avaliação do curso

ANOVA $^{\text {a }}$

\begin{tabular}{|rl|r|r|r|r|r|}
\hline \multicolumn{1}{|c|}{ Model } & \multicolumn{1}{c|}{$\begin{array}{c}\text { Sum of } \\
\text { Squares }\end{array}$} & df & Mean Square & F & Sig. \\
\hline 1 & Regression & 1,223 & 1 & 1,223 & 2,131 & $1^{145^{\mathrm{b}}}$ \\
& Residual & 323,057 & 563 &, 574 & & \\
& Total & 324,279 & 564 & & & \\
\hline
\end{tabular}

a. Dependent Variable: Normal Score of EXAM_TOT using Blom's Formula

b. Predictors: (Constant), Normal Score of Age using Blom's Formula

Quadro 118 - Análise residual para medida do grau de significância de R2 no Modelo

Coefficients $^{a}$

\begin{tabular}{|c|c|c|c|c|c|c|}
\hline \multirow[b]{2}{*}{ Mode } & & \multicolumn{2}{|c|}{ Unstandardized Coefficients } & \multirow{2}{*}{$\begin{array}{c}\begin{array}{c}\text { Standardized } \\
\text { Coefficients }\end{array} \\
\text { Beta } \\
\end{array}$} & \multirow[b]{2}{*}{$t$} & \multirow[b]{2}{*}{ Sig. } \\
\hline & & $\mathrm{B}$ & Std. Error & & & \\
\hline \multirow[t]{2}{*}{1} & (Constant) &, 000 &, 032 & &,- 008 &, 994 \\
\hline & $\begin{array}{l}\text { Normal Score of Age } \\
\text { using Blom's Formula }\end{array}$ &, 047 &, 032 &, 061 & 1,460 &, 145 \\
\hline
\end{tabular}

a. Dependent Variable: Normal Score of EXAM_TOT using Blom's Formula

Quadro 119 - Coeficiente Beta de Correlação entre idade e quantidade de aprovações nos exames do curso

A análise de regressão linear mostrou que a idade não foi uma variável de predição para a quantidade de aprovações nos exames $(\mathrm{R} 2=0,004, \mathrm{~F}(1,563)=$ 2.131 e $\beta=0,061, p=0,145)$. 


\section{Discussão}

A partir da análise de dados feita no capítulo anterior, passamos agora a discutir os resultados obtidos, resgatando as teorias que foram utilizadas para fundamentação, os objetivos de pesquisa e outras questões relevantes que percebemos ao longo do desenvolvimento do curso.

Primeiramente, gostaríamos de propor uma reflexão acerca do principal objetivo de pesquisa, baseado na associação entre a atividade de mediação em cursos online e a participação dos estudantes com vias a medir os efeitos no desempenho no curso. Fizemos esta associação através de uma pesquisa de campo baseada em um curso online ofertado pela PUC-Rio com 1.200 alunos matriculados. Neste curso inserimos o mediador pedagógico para moderação dos debates nos fóruns de discussão. Para medir os efeitos deste mediador, criamos um grupo de controle dentro do próprio curso.

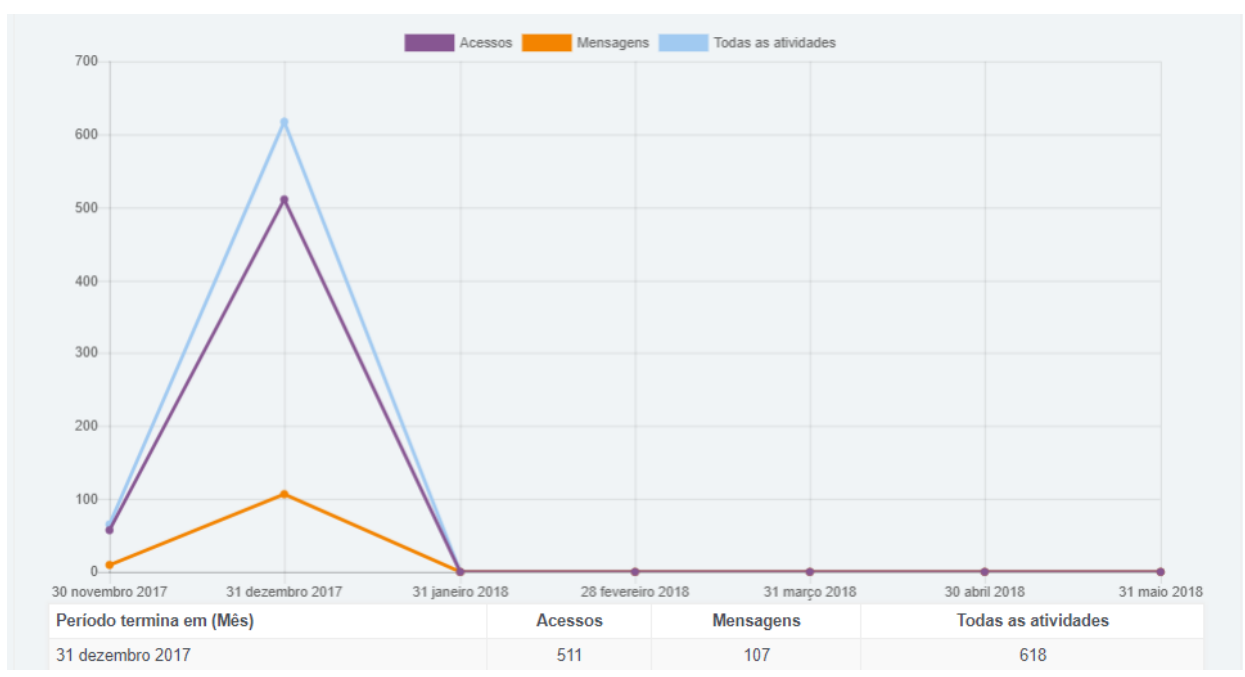

Figura 65 - Mapeamento de Interações do Mediador ao longo do período do curso

Os resultados obtidos a partir da análise de dados demonstraram que não houve diferença entre o grupo de alunos que foi exposto ao mediador de fórum ao longo de todo o curso, do grupo de alunos que não teve nenhum contato com o mediador (grupo de controle). Ou seja, a partir de análises estatísticas dos dados coletados no ambiente virtual de aprendizagem do curso, podemos observar que não houve nenhuma diferença significativa entre os dois grupos. Isso vale tanto para as variáveis que estavam medindo o comportamento dos alunos nas 
atividades do curso, quanto as variáveis de medida de desempenho, representada pelos exames de avaliação em cada um dos módulos. Interpretamos este resultado da seguinte forma:

- No ambiente online, a interação está permanentemente mediada pela tecnologia digital, mais precisamente a ferramenta de fóruns de discussão no caso do curso realizado. Foi o que identificamos no capítulo 5 como o processo de midiatização. A partir dos resultados obtidos, interpretamos que a ferramenta tecnológica, além de funcionar como o meio, também funciona como uma barreira comunicativa. Ao analisar as estatísticas descritivas dos fóruns, percebe-se um nível muito baixo tanto na quantidade de postagem quanto no tamanho das postagens dos alunos. Na quantidade total de postagens nos fóruns, incluindo os dois grupos, a média foi próxima a um, ou seja, em todo o período do curso, em média, as pessoas fizeram somente uma postagem. Some-se a isso o tamanho destas postagens que foi em torno de 25 palavras (considerando uma média de quatro caracteres por palavra), pode-se perceber que além de postar pouco, estas postagens ainda foram relativamente curtas se considerarmos o grau de subjetividade dos tópicos propostos para discussão. Mesmo se extrairmos os não participantes e mantivermos somente aqueles que participaram nos debates, o resultado ainda fica baixo. Podemos contabilizar aproximadamente três postagens por participante e cada uma delas com 150 palavras, ou seja, a comunicação total típica de um participante ativo de fórum ao longo de todo curso seria de 450 palavras, valor próximo a um quarto de lauda. Acreditamos que se este debate fosse feito verbalmente, a participação seria muito maior. Nos parece que a mídia digital funcionou como uma barreira comunicativa. Caberia um estudo futuro utilizando outras ferramentas de comunicação digital, mantendo obviamente as proporções do curso (MOOC). Temos notícias de ferramentas de comunicação em massa que utilizam recursos de compartilhamento assíncrono de voz. Um exemplo, muito utilizada em jogos online massivos (MMO), são as 
ferramentas Discord ${ }^{26}$ e TeamSpeak ${ }^{27}$. Até que ponto uma mudança de ferramenta iria alterar substancialmente os resultados da pesquisa?

- O papel do mediador ficou limitado aos fóruns de discussão, que eram a ferramenta de interatividade do curso. As mensagens privadas não foram consideradas, assim como as postagens no fórum inicial de apresentação (quando os alunos recebem as boas vindas ao curso e tem uma chance de se apresentar e falar de seus objetivos no curso). Consideramos que estas postagens tinham uma conotação pessoal, não tendo relação direta com o conteúdo de aprendizagem do curso. Sendo assim, a partir da análise dos resultados, percebemos os resultados da mediação ficam muito limitados se o papel do mediador estiver restrito aos fóruns de discussão. Isso ficou evidente também se apurarmos a quantidade de interações feitas pelo mediador nos fóruns. Como apontado na figura, a mediadora realizou 511 acessos no período do curso e realizou 107 postagens. Isso demonstra, em primeiro lugar, que muitas vezes a mediadora acessou os fóruns, mas não percebeu oportunidades de interação com os participantes. Também fica evidente que, considerando o número de alunos do curso e duração do curso, o número absoluto de postagens da mediadora não foi tanto expressivo. Fica o questionamento se a mediadora não teve a habilidade para encontrar mais oportunidades de interação ou se a própria restrição de atuação dentro dos fóruns foi um fator limitante para o resultado. Até que ponto os resultados teriam sido diferentes caso a mediadora expandisse sua atuação para uma intervenção via mensagens diretas com os participantes? Ou se tivesse a chance de abrir novos tópicos de discussão baseados em sua percepção de encaminhamento das conversas? Fica como sugestão para pesquisa futura uma nova edição do curso onde o mediador tem mais liberdade de atuação no curso, expandindo o grupo de controle não só para os fóruns de

${ }^{26} \mathrm{O}$ aplicativo Discord pode ser acessado através do link www.discordapp.com.

${ }^{27} \mathrm{O}$ aplicativo TeamSpeak pode ser acessado através do link www.teamspeak.com. 
discussão, mas para todo o ambiente virtual de aprendizagem (curso como um todo).

- Apesar de não podermos afirmar estatisticamente que houve uma diferença significativa entre os grupos, podemos perceber que se observarmos algumas variáveis de forma isolada, houve uma diferença marginalmente significativa entre os grupos. $\mathrm{O}$ que chama a atenção é que esta diferença é positiva em relação ao grupo de controle, que não sofreu interferência do mediador de fórum. Por exemplo, na quantidade de postagens e tamanho das postagens nos módulos 2 e 3 do curso, o grupo de controle teve uma média levemente superior. Se abstrairmos do fato que esta diferença representa um percentual muito baixo da variância, conforme apresentado nos resultados da pesquisa, observamos um resultado, de certa forma, oposto ao esperado. Ou seja, as pessoas que foram expostas ao mediador tiveram um nível menor de interação no curso. Nos questionamos o quanto a simples presença de um agente externo intimidou os participantes do curso a expressarem suas opiniões. Cabe realçar que o mediador interferiu no debate provendo um feedback instantâneo em relação a algumas opiniões expressas pelos participantes, mas este feedback era público. Ou seja, todos podiam ver o feedback do mediador. Até que ponto a fala do mediador, transportado pela mídia digital em forma de texto, não estaria provocando algum ruído na comunicação? Seria esse um efeito mínimo que observamos no grupo de controle, mas que deveria ser explorado em uma pesquisa futura?

- Com relação ao desempenho dos alunos no curso, utilizamos como parâmetro os exames de avaliação tipo múltipla escolha que eram aplicados ao final de cada um dos módulos do curso. A análise de resultado demonstrou que não houve diferença entre os grupos. Este resultado era esperado tendo em vista que não houve diferença no comportamento dos alunos em relação às atividades do curso (material de estudo). Ou seja, se não houve diferença na dedicação dos alunos no curso, não deveria haver diferença no desempenho. Isso nos levantou uma questão adicional. Haveria então alguma 
diferença no desempenho dos alunos no exame? Ou simplesmente o exame de avaliação não explica nada no curso. Isso nos conduziu a uma outra vertente de análise, associada às características demográficas.

Além medir os efeitos de agrupamento (Grupos Hipótese/Controle), também analisamos os efeitos das variáveis demográficas no comportamento e desempenho dos participantes no curso. As quatro variáveis demográficas utilizadas para análise foram a idade do participante, o sexo, a região geográfica onde o mesmo estava localizado e o nível de formação acadêmica. Os resultados não apontaram nenhuma diferença significativa entre as variáveis demográficas e as variáveis de atividades no curso. As variáveis que mais apresentaram correlação positiva foram idade com tamanho da postagem - algo como, pessoas com mais idade escrevem textos mais longos. Porém, esta relação explicou somete 2,3\% da variância - sendo assim, não consideramos que seja uma resposta tão significativa.

O resultado apontou que não havia diferença entre os grupos e não havia diferença entre as características demográficas. Partimos então para avaliar a variação no desempenho a partir das variáveis de atividades no curso. Consideramos que se não houvesse diferença no desempenho do curso, esta variável não estaria explicando nada e não faria sentido no modelo. Para realizar o teste, aplicamos uma análise de regressão nos dados normalizados pela transformação de Blom. Ao final o modelo explicou 66,2\% da variância (R2 = $0,662, \mathrm{~F}(3,561)=369,324, \mathrm{p}=0,000)$.

\begin{tabular}{|c|c|c|c|c|c|c|c|c|c|}
\hline \multicolumn{10}{|c|}{ Model Summary } \\
\hline \multirow[b]{2}{*}{ Model } & \multirow[b]{2}{*}{$\mathrm{R}$} & \multirow[b]{2}{*}{ R Square } & \multirow[b]{2}{*}{$\begin{array}{l}\text { Adjusted R } \\
\text { Square }\end{array}$} & \multirow[b]{2}{*}{$\begin{array}{l}\text { Std. Error of } \\
\text { the Estimate }\end{array}$} & \multicolumn{5}{|c|}{ Change Statistics } \\
\hline & & & & & $\begin{array}{c}\text { R Square } \\
\text { Change }\end{array}$ & F Change & df1 & $\mathrm{df} 2$ & $\begin{array}{c}\text { Sig. F } \\
\text { Change }\end{array}$ \\
\hline 1 & $815^{\mathrm{a}}$ &, 664 &, 662 &, 4407934 & 664 & 369,324 & 3 & 561 &, 000 \\
\hline
\end{tabular}

a. Predictors: (Constant), Normal Score of VIDEO_TOT using Blom's Formula, Normal Score of CRC_TOT using Blom's Formula, Normal Score of FOR_TOT using Blom's Formula

Quadro 120 - Modelo de Regressão Linear simples para correção entre as atividades do curso e aprovações nos exames de avaliação

Entretanto, nem todas as correlações foram significativas. A quantidade total de postagens nos fóruns de discussão $(\beta=0,524, \mathrm{p}=0,000)$ e a quantidade total de videoaulas visualizadas no curso $(\beta=0,427, p=0,000)$ emergiram com 
correlação significativa, enquanto o tamanho das postagens não correlacionou com o desempenho como uma boa variável de predição $(\beta=-0,032, p=0,254)$.

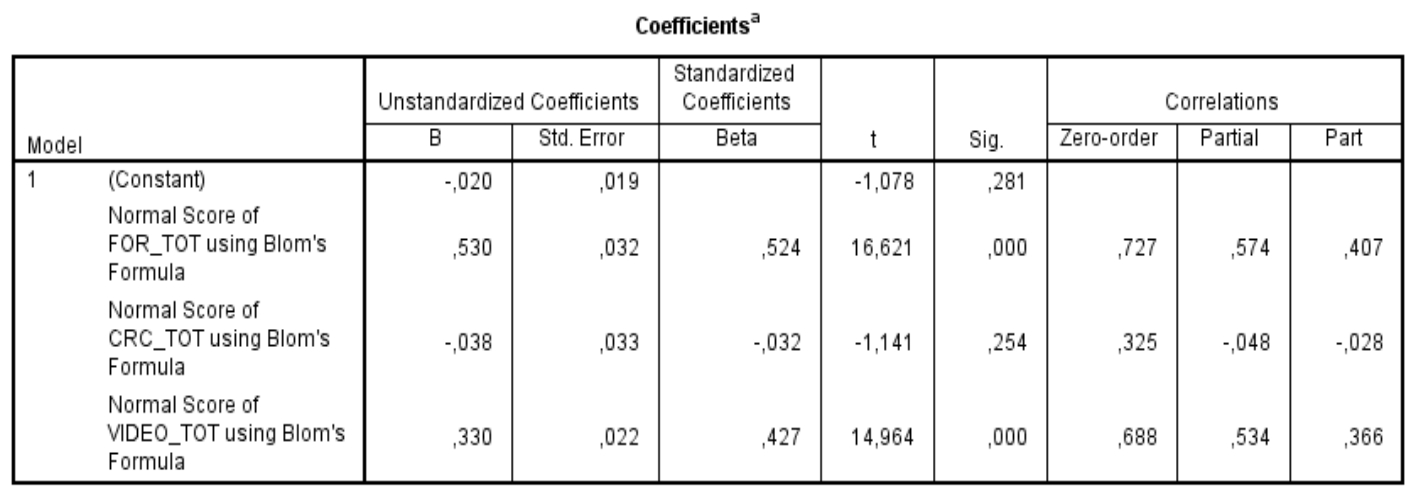

a. Dependent Variable: Normal Score of EXAM_TOT using Blom's Formula

Quadro 121 - Coeficiente Beta de Correlação entre as atividades do curso e quantidade de aprovações nos exames de avaliação

\begin{tabular}{|c|c|c|c|c|c|c|c|c|c|}
\hline \multicolumn{10}{|c|}{ Model Summary } \\
\hline \multirow[b]{2}{*}{ Model } & \multirow[b]{2}{*}{$\mathrm{R}$} & \multirow[b]{2}{*}{ R Square } & \multirow[b]{2}{*}{$\begin{array}{c}\text { Adjusted R } \\
\text { Square }\end{array}$} & \multirow[b]{2}{*}{$\begin{array}{l}\text { Std. Error of } \\
\text { the Estimate }\end{array}$} & \multicolumn{5}{|c|}{ Change Statistics } \\
\hline & & & & & $\begin{array}{c}\text { R Square } \\
\text { Change }\end{array}$ & F Change & df1 & $\mathrm{df} 2$ & $\begin{array}{c}\text { Sig. F } \\
\text { Change }\end{array}$ \\
\hline 1 &, $727^{\mathrm{a}}$ &, 529 &, 528 &, 5209024 & .529 & 632,106 & 1 & 563 &, 000 \\
\hline 2 & $814^{\mathrm{b}}$ &, 663 &, 662 &, 4409122 & 134 & 223,809 & 1 & 562 &, 000 \\
\hline
\end{tabular}

Quadro 122 - Modelo de regressão Stepwise com as duas variáveis de predição (postagens e visualizações de vídeo)

Um modelo de análise de regressão Stepwise com as duas variáveis de predição significativas demonstrou o quanto que cada uma contribuiu para a explicação de 66,2\% da variância. A quantidade de postagens nos fóruns de discussão explicou 52,8\% da variância $(\mathrm{R} 2=0,528, \mathrm{~F}(1,563)=632,106, \mathrm{p}$ $=0,000)$, enquanto a quantidade total de visualização de vídeos adicionou 13,4\% de explicação ao modelo (R2_Change $=0,134$, F_Change $(1,562)=223,809, \mathrm{p}=$ 0,000), totalizando $66,2 \%$ de explicação.

Portanto, podemos concluir que os participantes do curso que mais se dedicaram, realizando postagens nos fóruns de discussão e assistindo mais vezes às videoaulas do curso, também tiveram melhor desempenho no curso. Isso é um indicador de que a avaliação foi de fato compatível com a aprendizagem no curso e serviu como um parâmetro de desempenho para os alunos. O fato de não haver diferença de desempenho no curso entre os grupos, não pode ser atribuído ao 
exame. De fato, a inserção do mediador não afetou o desempenho final dos alunos no curso.

Um outro aspecto de discussão que gostaríamos de levantar, trata da taxa de abandono do curso. Inicialmente nos propusemos a tentar medir a influência da qualidade da comunicação em MOOC nos índices de conclusão do curso, tendo em vista que estes giram em torno de $8 \%$ do total de inscritos (HO ET AL, 2014). No caso do MOOC que realizamos, o funil de inscrições demonstrou que esta taxa ficou em $22 \%$, ou seja, cerca de três vezes acima da média. A figura a seguir ilustra o funil do curso, considerando que a diferença entre matriculados e inscritos é que os inscritos fizeram, além da matrícula no curso, a inscrição na plataforma de aulas do curso, que era o segundo passo. Ou seja, aqueles que somente se matricularam no curso, mas não se inscreveram, são os alunos que receberam o usuário e senha, mas nunca realizaram o acesso na plataforma de aulas. A diferença de $7 \%$ entre inscritos e ativos, refere-se aqueles alunos que, apesar de terem realizado o acesso no ambiente virtual de aprendizagem, não realizaram nenhuma atividade no curso, nem mesmo a visualização do programa e as videoaulas. Os concluintes, são aqueles que cumpriram as atividades, realizaram as avaliações do curso e obtiveram o grau mínimo para aprovação.

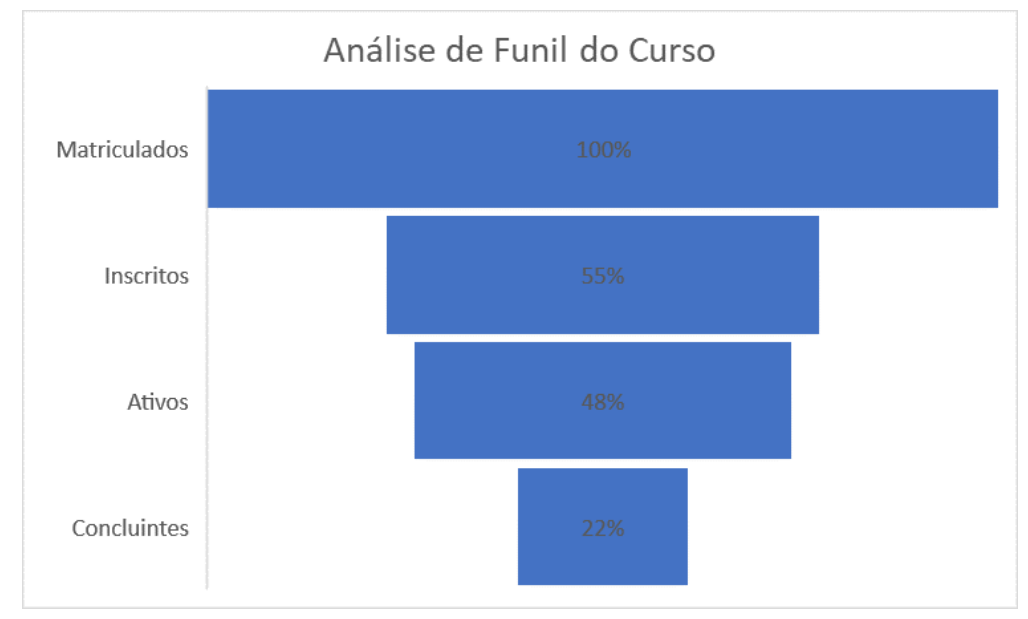

Figura 66 - Análise de Funil do Curso

Baseado na pesquisa realizada, não podemos extrair nenhuma relação de causalidade ou apresentar nenhum resultado conclusivo com relação ao índice de concluintes no curso que realizamos, mas a interpretação que fazemos para este resultado está associada a dois fatores. O primeiro fator é a quantidade de matriculados no curso, que apesar de bastante expressiva para um curso 
tradicional, é caracterizada como pequena para o padrão histórico dos MOOC. A média de matriculados nos MOOC realizados na plataforma EdX pelas Universidades de Harvard e MIT no ano de 2016 foi de 4.212 (CHUANG and HO, 2016). Entretanto, este mesmo estudo aponta para um declínio na quantidade de matriculados nos cursos MOOC destas instituições, conforme ilustrado no gráfico a seguir.

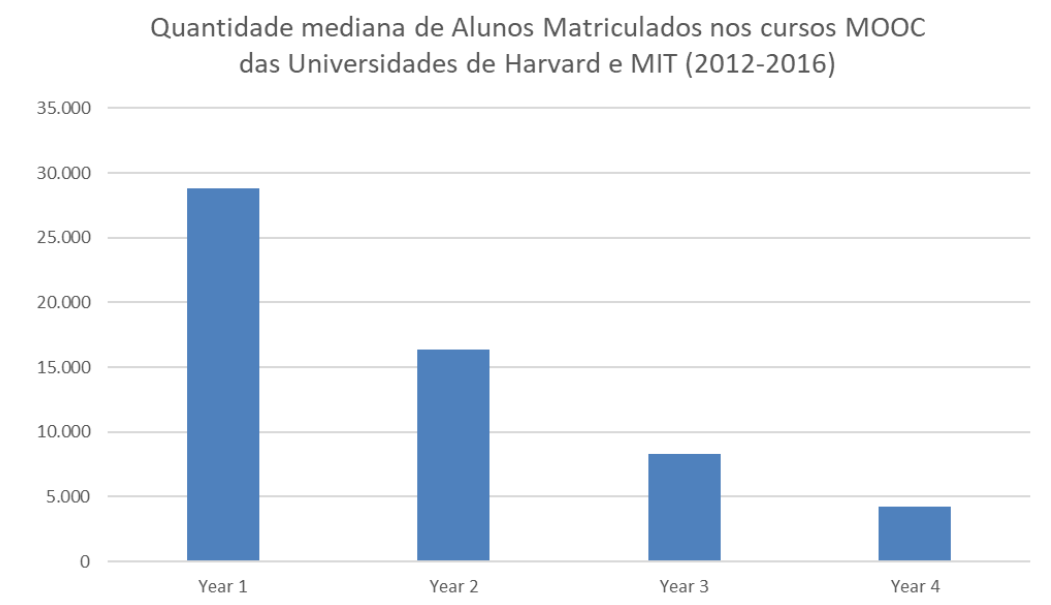

Figura 67 - Quantidade de Alunos Matriculados nos cursos MOOC das Universidades de Harvard e MIT (2012-2016). Fonte: CHUANG and HO, 2016

Se considerarmos que esta tendência tenha continuado ao longo do ano de 2017, é possível inferir que a mediana ficou ainda menor. Ou seja, o número de matriculados no MOOC de Introdução às Criptomoedas não ficou tão abaixo dos casos comparativos das Universidades de Harvard e MIT. De qualquer forma, a comparação com as edições mais atuais destes cursos, ainda aponta para uma média de certificação superior (22\% no MOOC da pesquisa versus $6,3 \%$ na mediana do EdX). Isso nos remete ao segundo fator que acreditamos explicar a quantidade superior de alunos certificados, que é a questão do idioma. Os cursos da EdX são ofertados em inglês, com abrangência global. Acreditamos que muitas pessoas que fazem estes cursos apresentam dificuldades com o idioma, o que certamente deve refletir na taxa de conclusão. No caso do nosso MOOC, ofertado em português, acreditamos que este problema não existiu, tendo em vista que praticamente a totalidade os estudantes eram brasileiros, cujo português é um idioma nativo. Isso nos remete a refletir sobre a questão da regionalização dos cursos MOOC. Até que ponto o idioma local afeta nas taxas de conclusão do curso? Seria correto afirmar, a partir dos dados coletados nesta pesquisa e 
comparados com os dados de Harvard e MIT, que o fator regionalização é responsável por um incremento de até 3 vezes nas taxas de aprovação dos cursos MOOC? Esta interpretação, que fica como uma sugestão para pesquisa futura, se comprovado, seria um interessante argumento no suporte ao desenvolvimento das plataformas regionais de MOOC, como no caso do Brasil, a plataforma Veduca ${ }^{28}$, dentre outras disponíveis. O mesmo argumento vale para a oferta de cursos regionais em plataformas internacionais, como vem acontecendo gradativamente com alguns exemplos como a própria Coursera e EdX, que já oferecem cursos em Português e Espanhol.

\footnotetext{
${ }^{28}$ Veduca é uma plataforma de educação a distância. Todo o conteúdo, baseado em videoaulas é aberto e gratuito, configurando o serviço como um tipo de xMOOC. Ela conta com mais de 800 mil usuários e cursos feitos por instituições parceiras como a USP. O serviço pode ser acessado no endereço https://veduca.org.
} 


\section{8 \\ Conclusão}

Realizamos uma pesquisa de campo representada por um curso online aberto e massivo, realizado nos meses de novembro e dezembro de 2017 utilizando o ambiente virtual de aprendizagem da PUC-Rio. Neste curso inserimos a figura de um mediador, cujo objetivo era de estimular o debate nos fóruns de discussão com possíveis efeitos na participação e desempenho dos alunos. Um grupo de controle foi criado para viabilizar um estudo comparativo de resultados. A participação dos alunos no curso, foi instrumentalizada através de variáveis associadas às atividades no curso, com por exemplo a participação nos fóruns de discussão, a quantidade de visualização do material de estudo, o tamanho das postagens, dentre outras. Além disso, ampliamos o estudo para avaliar também os efeitos do mediador no comportamento dos alunos no curso, representado pelas variáveis de atividades no curso (ex.: assistir as videoaulas) e no desempenho dos alunos no curso, representado pela variável de avalição (exame).

Os resultados das análises demonstraram que, dentro do experimento realizado, não houve diferença entre os grupos. Ou seja, a inserção de um agente de mediação de fóruns com o intuito de estimular a participação não surtiu efeito no comportamento dos alunos perante as atividades pedagógicas do curso e nos resultados dos exames de avaliação. Os resultados desta pesquisa, apesar de limitados, nos levam a crer que o estímulo à participação a partir de um mediador pedagógico deve acontecer de forma ampla no curso e não só em uma atividade específica, que no caso da nossa pesquisa foi o fórum de discussão. Tivemos a percepção que em cursos online, especialmente no formato xMOOC, que foi o tipo de curso que aplicamos, os participantes adotam uma postura mais individualista e orientada para cumprir um programa pré-definido. As evidências nos dados que coletamos sugerem uma baixa participação em debates e outras formas de atividade mais dialógica. Pouca quantidade de postagens e tipicamente curtas, o que aponta para uma baixa troca entre os participantes. Os mesmos parecem enxergar os fóruns de discussão como uma atividade que deveria ser cumprida, como requisito do curso. Não enxergam estes fóruns como um espaço aberto de troca e colaboração. Portanto, não nos parece que incrementos nos níveis de participação e desempenho no curso serão atingidos através da inserção 
de um mediador focado somente no recurso de fóruns de discussão. Por outro lado, acreditamos que um mediador pedagógico com uma abordagem mais ampla dentro e, talvez, até mesmo extrapolando as fronteiras do ambiente virtual de aprendizagem, teria um impacto significativo no incremento da participação e desempenho de estudantes em cursos do tipo MOOC.

Um outro aspecto que notamos na experiência com um todo, foi a importância da qualidade do material didático. Apesar de não termos explorado este aspecto na pesquisa, tivemos a percepção que, em cursos MOOC, incrementos na qualidade dos recursos educacionais do curso (vídeos, apostilas, slides, etc.) tem uma correlação direta com incrementos na participação e desempenho dos alunos. Este impacto nos pareceu ser tão forte ou até mesmo maior que o impacto da mediação pedagógica. Se esta hipótese que estamos levantando for verdadeira, faria muito sentido buscar um foco na própria qualidade do conteúdo e do projeto didático como formas de melhoria nos resultados de atividade e desempenho no curso online. Também propomos uma reflexão sobre os efeitos da inserção de mecanismos que criem incentivo para maior participação dos alunos. Sabemos que existe toda uma pesquisa em torno deste tópico de estímulos ao aumento da participação em cursos online através da inserção de incentivos, como por exemplo a oferta de distintivos (badges), concessão de créditos por atividades, dentre outros.

Apontamos a seguir algumas sugestões para pesquisa futura que percebemos, a partir das discussões e das conclusões apresentadas neste trabalho:

- Realizar uma análise qualitativa do conteúdo dos fóruns, comparando as postagens dos alunos do grupo Hipótese com o grupo de controle. Avaliar se houve diferença na qualidade das respostas a partir dos temas propostos de discussão;

- Replicar a pesquisa alterando a ferramenta de debate (fórum no Moodle) por outras ferramentas que viabilizem participação via telefone celular e/ou participação via mensagens de voz (ex.: aplicativo Discord);

- Realizar um novo curso MOOC expandindo o grupo de controle para todo o ambiente virtual de aprendizagem, ao mesmo tempo que o mediador passa a interagir não somente nos fóruns de discussão, mas também em toda plataforma - eventualmente até mesmo 
extrapolando estas fronteiras e buscando oportunidades de interação com os estudantes fora da plataforma (ex.: nas redes sociais);

- Conforme citamos anteriormente, este curso obteve uma taxa de aprovação três vezes maior do que a média dos cursos de Harvard e MIT. Considerando que validamos a eficácia do exame a partir do momento que analisamos uma correlação positiva entre os alunos que se dedicaram aos estudos e o resultado de aprovação nos exames do curso, levantamos a hipótese que a regionalização dos cursos MOOC afeta positivamente o nível de aprovação. Sugerimos replicar o curso em uma versão em inglês, mais acessível para o público internacional, testando a hipótese de redução da taxa de alunos aprovados em relação ao presente curso realizado na pesquisa, cujos participantes eram quase que na sua totalidade nativos no idioma regional do curso;

- Avaliar os efeitos da inserção de tipos de incentivos (ex.: badges, pontos, créditos, recompensas) nos níveis de engajamento de alunos e no desempenho nos cursos online. Apesar de reconhecermos que já existem diversos estudos na área, assim como o caráter controverso deste tipo de iniciativa, também entendemos que este tipo de estudo é relevante para compreensão das atuais motivações dos alunos em um momento em que novas formas de gerar conhecimento estão surgindo muito além das fronteiras das instituições de ensino e dos cursos. 
9

\section{Referências bibliográficas}

ALCORN, B.; CHRISTENSEN, G.; EMANUEL, J. E. Who take MOOCs. For higher education, the devil is in the data, Higher Education. Retrieved from http://www. newrepublic. com/article/116013/mooc-studentsurvey-who-enrolls-online-education, 2014.

BARBER, Michael et al. An avalanche is coming. Higher Education and the revolution ahead, p. 73, 2013.

BATES, Tony. Broadcasting in education: An evaluation. Constable \& Company Limited, 1984.

BATES, Tony. Teaching in a digital age. Glokalde, v. 1, n. 3, 2015.

BELANGER, Yvonne; THORNTON, Jessica. Bioelectricity: A quantitative approach Duke University's first MOOC. 2013.

BIOCCA, Frank. The Cyborg's Dilemma: Progressive Embodiment in Virtual Environments [1]. Journal of Computer-Mediated Communication, v. 3, n. 2, p. 0-0, 1997.

BLOOM, Benjamin S. et al. Handbook on formative and summative evaluation of student learning. 1971.

BONK, C. J., GRAHAM, C. R. (Eds.). (in press). Handbook of blended learning: Global Perspectives, local designs. San Francisco, CA: Pfeiffer Publishing, 2006.

CENSO, EAD. ABED. Associação Brasileira de Educação a Distância: Relatório analítico da aprendizagem a distância no Brasil, 2016.

CHUANG, Isaac; HO, Andrew Dean. HarvardX and MITx: Four Years of Open Online Courses--Fall 2012-Summer 2016. 2016.

CLARÀ, Marc; BARBERÀ, Elena. Learning online: massive open online courses (MOOCs), connectivism, and cultural psychology. Distance Education, v. 34, n. 1, p. 129-136, 2013.

DANIEL, John. Making sense of MOOCs: Musings in a maze of myth, paradox and possibility. Journal of interactive Media in education, $v$. 2012, n. 3, 2012. 
DANIEL, John. MOOCs: What lies beyond the trough of disillusionment. In: LINC 2013 Conference. 2013.

DAVIES, Jo; GRAFF, Martin. Performance in e-learning: online participation and student grades. British Journal of Educational Technology, v. 36, n. 4, p. 657-663, 2005.

ENGLE, W. UBC MOOC Pilot: Design and Delivery, 2014.

FREDERICKSEN, Eric et al. Student satisfaction and perceived learning with on-line courses: Principles and examples from the SUNY learning network. Journal of Asynchronous learning networks, v. 4, n. 2, p. 741, 2000.

FRANCIOSI, Beatriz Regina Tavares; MEDEIROS, MF de; COLLA, Anamaria Lopes. Caos, criatividade e ambientes de aprendizagem. Educação a Distância-Cartografias Pulsantes em Movimento. Porto Alegre: EDIPUCRS,. cap7, p. 129-149, 2003.

GROVER, S. et al. The MOOC as distributed intelligence: dimensions of a framework \& evaluation of MOOCs. In: 10th International Conference on Computer Supported Collaborative Learning, Madison, USA, 2013.

HEW, Khe Foon; CHEUNG, Wing Sum. Students' and instructors' use of massive open online courses (MOOCs): Motivations and challenges. Educational research review, v. 12, p. 45-58, 2014.

HRASTINSKI, Stefan. What is online learner participation? A literature review. Computers \& Education, v. 51, n. 4, p. 1755-1765, 2008.

HO, A. D. et al. MITx: The first year of open online courses, fall 2012summer 2013. Social Science Research Network (1 2014). http://ssrn. com/abstract, v. 2381263, 2014.

HOLLANDS, Fiona M. et al. MOOCs: Expectations and reality. Center for Benefit-Cost Studies of Education, Teachers College, Columbia University, p. 138, 2014.

JORDAN, Katy. Massive open online course completion rates revisited: Assessment, length and attrition. The International Review of Research in Open and Distributed Learning, v. 16, n. 3, 2015.

KRAUSE, Steven D. "Among the Greatest Benefactors of Mankind": What the Success of Chalkboards Tells Us about the Future of Computers in the Classroom. The Journal of the Midwest Modern Language Association, v. 33, n. 2, p. 6-16, 2000.

KOLLER, Daphne et al. Retention and intention in massive open online courses: In depth. Educause review, v. 48, n. 3, p. 62-63, 2013. 
KOLOWICH, Steve; NEWMAN, J. The minds behind the MOOCs. The Chronicle of Higher Education, v. 18, 2013.

KOP, Rita; HILL, Adrian. Connectivism: Learning theory of the future or vestige of the past?. The International Review of Research in Open and Distributed Learning, v. 9, n. 3, 2008.

LOIZZO, Jamie; ERTMER, Peggy A. MOOCocracy: the learning culture of massive open online courses. Educational Technology Research and Development, v. 64, n. 6, p. 1013-1032, 2016.

MASETTO, Marcos T. Mediação pedagógica e o uso da tecnologia. MORAN, JM; MASETTO, MT e BEHRENS, MA Novas tecnologias e mediação pedagógica. 14aㅡ ed. Campinas: Papirus, 2000.

MEANS, B., TOYAMA, Y., MURPHY, R., BAKIA, M., JONES, K. Evaluation of Evidence-Based Practices in Online Learning: A MetaAnalysis and Review of Online Learning Studies. Technical Report. U.S. Department of Education, Washington, D.C, 2010.

MILLIGAN, Colin; LITTLEJOHN, Allison; MARGARYAN, Anoush. Patterns of engagement in connectivist MOOCs. Journal of Online Learning and Teaching, v. 9, n. 2, p. 149, 2013.

MOLON, Susana I. Cultura-A dimensão psicológica e a mudança histórica e cultural. In: Trabalho apresentado na III Conferência de Pesquisa Sócio-cultural, Campinas, SP. 2000.

MOORE, Michael G. Three types of interaction. The American Journal of Distance Education, 1989.

MORRIS, Libby V.; FINNEGAN, Catherine; WU, Sz-Shyan. Tracking student behavior, persistence, and achievement in online courses. The Internet and Higher Education, v. 8, n. 3, p. 221-231, 2005.

PERAYA, Daniel. La formation à distance: un dispositif de formation et de communication médiatisées. Une approche des processus de médiatisation et de médiation. Calidoscópio, v. 4, n. 3, p. 200-204, 2006.

PRADO, Maria Elisabette Brisola Brito. A Mediação Pedagógica: suas relações e interdependências. In: Brazilian Symposium on Computers in Education (Simpósio Brasileiro de Informática na Educação-SBIE). 2006. p. 101-110.

RODRIGUES, Rodrigo Lins et al. Discovery engagement patterns MOOCs through cluster analysis. IEEE Latin America Transactions, v. 14, n. 9, p. 4129-4135, 2016.

ROGERS, Everett M. Diffusion of innovations. Simon and Schuster, 2010. 
ROSSELLE, Marilyne; CARON, Pierre-André; HEUTTE, Jean. A typology and dimensions of a description framework for MOOCs. In: European MOOCs Stakeholders Summit 2014, eMOOCs, p. 130-139, 2014.

SCHNEIDER, Emily. Welcome to the moocspace: a proposed theory and taxonomy for massive open online courses. In: Proceedings of the Workshops at the 16th International Conference on Artificial Intelligence in Education. p. 2-9, 2013.

SIEMENS, G. Connectivism: A learning theory for the digital age. International journal of instructional technology and distance learning, v. 2, n. 1, p. 3-10, 2005.

SIEMENS, George. Knowing knowledge. Lulu. com, 2006.

SMITH, Becky; ENG, Min. MOOCs: A learning journey. In: Hybrid learning and continuing education. Springer Berlin Heidelberg, 2013. p. 244-255.

VERGARA, S. Sugestão para estruturação de um projeto de pesquisa. Caderno de Pesquisa EBAP. Rio de Janeiro: Volume 02 FGV, 1991.

VONDERWELL, Selma; ZACHARIAH, Sajit. Factors that influence participation in online learning. Journal of Research on Technology in education, v. 38, n. 2, p. 213-230, 2005.

YOUSEF, Ahmed Mohamed Fahmy et al. MOOCs-A Review of the Stateof-the-Art. In: CSEDU (3). 2014. p. 9-20.

YOUNG, J.R. (2002). 'Hybrid' teaching seeks to end the divide between traditional and online instruction. The Chronicle of Higher Education. March 22, p. A33, 2002.

WATSON, William R.; KIM, Woori; WATSON, Sunnie Lee. Learning outcomes of a MOOC designed for attitudinal change: A case study of an Animal Behavior and Welfare MOOC. Computers \& Education, v. 96, p. 83-93, 2016.

WILLIAMS, C. Learning on-line: A review of recent literature in a rapidly expanding field. Journal of Further and Higher Education, number 26, pp. 263-272, 2002.

XING, Wanli et al. Temporal predication of dropouts in MOOCs: Reaching the low hanging fruit through stacking generalization. Computers in Human Behavior, v. 58, p. 119-129, 2016. 
$\underline{\text { Anexo I }}$

Carta dos Professores de Filosofia da Universidade de São José, Califórnia.

\section{"An Open Letter to Professor Michael Sandel from the Philosophy Department at San José State University}

April 29, 2013

Dear Professor Sandel,

San José State University recently announced a contract with edX (a company associated with MIT and Harvard) to expand the use of online blended courses. The SJSU Philosophy Department was asked to pilot your JusticeX course, and we refused. We decided to express to you our reasons for refusing to be involved with this course, and, because we believe that other departments and universities will sooner or later face the same predicament, we have decided to share our reasons with you publicly.

There is no pedagogical problem in our department that JusticeX solves, nor do we have a shortage of faculty capable of teaching our equivalent course. We believe that long-term financial considerations motivate the call for massively open online courses (MOOCs) at public universities such as ours. Unfortunately, the move to MOOCs comes at great peril to our university. We regard such courses as a serious compromise of quality of education and, ironically for a social justice course, a case of social injustice.

WHAT ARE THE ESSENTIAL COMPONENTS OF A GOOD QUALITY EDUCATION IN A UNIVERSITY?

First, one of the most important aspects of being a university professor is scholarship in one's specialization. Students benefit enormously from interaction with professors engaged in such research. The students not only have a teacher who is passionate, engaged and current on the topic, but, in classes, independent studies, and informal interaction, they are provided the opportunity to engage a topic deeply, thoroughly, and analytically in a dynamic and up-to-date fashion. A social justice course needs to be current since part of its mission is the application of conceptions of justice to existing social issues. In addition to providing students with an opportunity to engage with active scholars, expertise in the physical classroom, sensitivity to its diversity, and familiarity with one's own students are simply not available in a one-size-fits-all blended course produced by an outside vendor.

Second, of late we have been hearing quite a bit of criticism of the traditional lecture model as a mismatch for today's digital generation. Anat Agarwal, edX President, has described the standard professor as basically just "pontificating" and "spouting content," a description he used ten times in a recent press conference here at SJSU. Of course, since philosophy has traditionally been taught using the Socratic method, we are largely in agreement as to the inadequacy of lecture alone. But, after all the rhetoric questioning the effectiveness of the antiquated method of lecturing and note taking, it is telling to discover that the core of edX's JusticeX is a series of videotaped lectures that include excerpts of Harvard students making comments and taking notes. In spite of our admiration for your ability to lecture in such an engaging way to such a large audience, we believe that having a scholar teach and engage his or her own 
students in person is far superior to having those students watch a video of another scholar engaging his or her students. Indeed, the videos of you lecturing to and interacting with your students is itself a compelling testament to the value of the in-person lecture/discussion.

In addition, purchasing a series of lectures does not provide anything over and above assigning a book to read. We do, of course, respect your work in political philosophy; nevertheless, having our students read a variety of texts, perhaps including your own, is far superior to having them listen to your lectures. This is especially important for a digital generation that reads far too little. If we can do something as educators we would like to increase literacy, not decrease it.

Third, the thought of the exact same social justice course being taught in various philosophy departments across the country is downright scary something out of a dystopian novel. Departments across the country possess unique specializations and character and should stay that way. Universities tend not to hire their own graduates for a reason. They seek different influences. Diversity in schools of thought and plurality of points of view are at the heart of liberal education.

WHAT WOULD OUR STUDENTS LEARN ABOUT JUSTICE THROUGH A PURCHASED BLENDED COURSE FROM A PRIVATE VENDOR?

First, what kind of message are we sending our students if we tell them that they should best learn what justice is by listening to the reflections of the largely white student population from a privileged institution like Harvard? Our very diverse students gain far more when their own experience is central to the course and when they are learning from our own very diverse faculty, who bring their varied perspectives to the content of courses that bear on social justice.

Second, should one-size-fits-all vendor-designed blended courses become the norm, we fear that two classes of universities will be created: one, wellfunded colleges and universities in which privileged students get their own real professor; the other, financially stressed private and public universities in which students watch a bunch of video-taped lectures and interact, if indeed any interaction is available on their home campuses, with a professor that this model of education has turned into a glorified teaching assistant. Public universities will no longer provide the same quality of education and will not remain on par with well-funded private ones. Teaching justice through an educational model that is spearheading the creation of two social classes in academia thus amounts to a cruel joke.

\section{CAN TECHNOLOGY BE USED TO IMPROVE EDUCATION?}

Absolutely. Blended courses provide the opportunity to listen to lectures for a second or third time and enable class discussion sessions outside the usual constraints of time and space. For these very reasons many of the faculty in our department offer very high quality online and blended versions of a number of our offerings, including video-taped material we ourselves have developed. All of these offerings are continuously updated, and their use includes extensive interaction among students. In addition, they also involve extensive interaction with the professor teaching the course, something that is not available in MOOCs, which rely on videotaped lectures, canned exercises, and automated and peer grading.

When a university such as ours purchases a course from an outside vendor, the faculty cannot control the design or content of the course; therefore, we cannot 
develop and teach content that fits with our overall curriculum and is based on both our own highly developed and continuously renewed competence and our direct experience of our students' needs and abilities. In the short term, we might be able to preserve our close contact with our students, but, given the financial motivations driving the move to MOOCs, the prognosis for the long term is grim.

The use of technology, as history shows, can improve or worsen the quality of education -- but in a high-quality course, the professor teaching it must be able both to design the course and to choose its materials, and to interact closely with the students. The first option is not available in a pre-packaged course, and the second option is at grave risk if we move toward MOOCs.

\section{IT IS TIME TO CALL IT LIKE IT IS}

We believe the purchasing of online and blended courses is not driven by concerns about pedagogy, but by an effort to restructure the U.S. university system in general, and our own California State University system in particular. If the concern were pedagogically motivated, we would expect faculty to be consulted and to monitor quality control. On the other hand, when change is financially driven and involves a compromise of quality it is done quickly, without consulting faculty or curriculum committees, and behind closed doors. This is essentially what happened with SJSU's contract with edX. At a press conference (April 10, 2013 at SJSU) announcing the signing of the contract with edX, California Lieutenant Governor Gavin Newsom acknowledged as much: "The old education financing model, frankly, is no longer sustainable." This is the crux of the problem. It is time to stop masking the real issue of MOOCs and blended courses behind empty rhetoric about a new generation and a new world. The purchasing of MOOCs and blended courses from outside vendors is the first step toward restructuring the CSU.

Good quality online courses and blended courses (to which we have no objections) do not save money, but purchased-pre-packaged ones do, and a lot. With prepackaged MOOCs and blended courses, faculty are ultimately not needed. A teaching assistant would suffice to facilitate a blended course, and one might argue, paying a university professor just to monitor someone else's material would be a waste of resources. Public universities that have so long and successfully served the students and citizens of California will be dismantled, and what remains of them will become a hodgepodge branch of private companies.

Administrators of the CSU say they do not see a choice; they are trying to admit and graduate as many students as they can with insufficient funds. Whether they are right in complying with rather than resisting this, the discussion has to be honest and to the point. Let's not kid ourselves; administrators at the CSU are beginning a process of replacing faculty with cheap online education. In our case, we had better be sure that this is what we want to do because once the CSU or any university system is restructured in this way it will never recover.

Industry is demanding that public universities devote their resources to providing ready-made employees, while at the same time they are resisting paying the taxes that support public education. (California is the ninth largest economy in the world yet has one of the most poorly supported public education systems in the nation.) Given these twin threats, the liberal arts are under renewed attack in public universities. We believe that education in a democracy must be focused on responsible citizenship, and general education courses in the liberal arts are crucial to such education. The move to outside vendor MOOCs is especially troubling in light of this--it is hard to see how they can nourish the complex mix 
of information, attitudes, solidarity and moral commitment that are crucial to flourishing democracies.

We respect your desire to expand opportunities for higher education to audiences that do not now have the chance to interact with new ideas. We are very cognizant of your long and distinguished record of scholarship and teaching in the areas of political philosophy and ethics. It is in a spirit of respect and collegiality that we are urging you, and all professors involved with the sale and promotion of edX-style courses, not to take away from students in public universities the opportunity for an education beyond mere jobs training. Professors who care about public education should not produce products that will replace professors, dismantle departments, and provide a diminished education for students in public universities.

Sincerely and in solidarity,

The Department of Philosophy

San José State University" 


\section{Anexo II}

$\underline{\text { Carta resposta do Professor Michael Sandel, da Universidade de Harvard }}$

From: Michael Sandel, Anne T. and Robert M. Bass Professor of Government, Harvard

University

To: Steven Kolowich, The Chronicle of Higher Education

I strongly believe that online courses are no substitute for the personal engagement of teachers with students, especially in the humanities. A few years ago, with Harvard's support, I made my course "Justice" freely available online, as an experiment in open global access to the classroom. The goal was to enable anyone, anywhere, to have free access to the lecture videos, a discussion blog, and other educational materials.

This year, we made a version of the course available on the edX platform. I know very little about the arrangements edX made with San Jose State University, and nothing about the internal discussions at SJSU. My goal is simply to make an educational resource freely available--a resource that faculty colleagues should be free to use in whole or in part, or not at all, as they see fit.

The worry that the widespread use of online courses will damage departments in public universities facing budgetary pressures is a legitimate concern that deserves serious debate, at edX and throughout higher education. The last thing I want is for my online lectures to be used to undermine faculty colleagues at other institutions. 
$\underline{\text { Anexo III }}$

TERMO DE CONSENTIMENTO LIVRE E ESCLARECIDO PARA PESQUISA ONLINE

\author{
PONTIFÍCIA UNIVERSIDADE CATÓLICA DO RIO DE JANEIRO \\ Programa de Pós-Graduação em Educação
}

\title{
TERMO DE CONSENTIMENTO LIVRE E ESCLARECIDO PARA PESQUISA ONLINE
}

Você está sendo convidado a compartilhar seus dados de navegação no ambiente do curso "Introdução às Criptomoedas" para uma pesquisa na área de educação e mídias digitais, cujo objetivo é estudar a questão da qualidade na comunicação em ambientes de aprendizagem online. Acreditamos que ela seja importante para a discussão sobre novas ferramentas de comunicação que aumentem o engajamento de alunos, reduzem as taxas de evasão e aumentam a chance de sucesso em cursos online.

Com sua devida autorização, coletaremos dados no ambiente do curso, preservando seu anonimato e de todos os participantes e seguindo regras estritas de ética de acordo com as normas de nossa instituição. A seguir provemos informações complementares sobre a pesquisa.

Pesquisa: Qualidade na comunicação em cursos online abertos de escala massiva (MOOC)

\section{Pesquisadores Responsáveis:}

Prof. Luis Felipe Carvalho | luis.felipe@puc-rio.br | Tel. (21) 3527-1625 Doutorando

Prof. Dr. Gilda Helena Bernardino de Campos | gilda@ccead.puc-rio.br | Tel. (21) 3527-1454 - Orientadora

Justificativas: Considerando os altos índices de evasão em cursos abertos online e o baixo grau de engajamento dos alunos neste tipo de curso, nos propomos a estudar oportunidades de intervenção através de teorias da comunicação que se propõe a estimular a colaboração e diálogo entre os alunos do curso.

Metodologia: Toda coleta de dados será feita no próprio ambiente do curso e não acarretará nenhum tipo de trabalho ou ônus para o aluno participante. A partir destes dados coletados serão aplicados métodos estatísticos para análise dos dados e posterior discussão à luz das teorias utilizadas na base da pesquisa.

Sigilo e Privacidade: Sua privacidade será respeitada, ou seja, seu nome ou qualquer dado ou elemento que possa, de qualquer forma, identificar o participante, será mantido em sigilo. Os pesquisadores se responsabilizam pela guarda e confidencialidade dos dados, bem como a não exposição dos dados da pesquisa.

Autonomia: É assegurada a assistência durante toda a pesquisa, bem como me garantido o livre acesso a todas as informações e esclarecimentos adicionais sobre o estudo e suas consequências, enfim, tudo que eu queira saber antes, durante e depois da minha participação. 
Riscos, Desconfortos e Benefícios: Não antevemos nenhum tipo de risco ou desconforto para os participantes da pesquisa, tendo em vista que toda coleta de dados será feita de forma automatizada pelo sistema e não atrelada a identidade do participante. Não haverá nenhum tipo de demanda adicional caso você esteja de acordo em participar da pesquisa. Os dados coletados serão utilizados para melhorar a qualidade dos cursos online, que é de interesse de todos os participantes.

Por favor, faça sua opção com relação ao termo abaixo:

"Ao clicar na caixa de seleção abaixo, você declara de maneira voluntária, livre e esclarecida, que concorda em compartilhar seus dados de navegação no ambiente do curso para fins da pesquisa acima identificada. Você está ciente dos objetivos do estudo, dos procedimentos metodológicos, das garantias de confidencialidade e da possibilidade de esclarecimentos permanentes sobre os mesmos. Você está sendo informado que se trata de pesquisa em andamento no Programa de Pós-Graduação em Educação da PUC-Rio. Está claro que sua participação é isenta de despesas e que sua imagem, nome ou qualquer outra forma de identificação NÃO serão coletados, publicados ou divulgados de qualquer forma - seu anonimato será totalmente preservado. Você ainda está ciente de que, em qualquer momento durante o período do curso ou posterior, tem a liberdade de cancelar sua participação ou retirar seu consentimento, sem nenhuma penalização ou prejuízo que the possam ser imputados, bastando para isso um contato por e-mail com a equipe responsável pela pesquisa".

O Concordo em compartilhar, para fins de pesquisa acadêmica, os meus dados gerados no ambiente do curso, mantendo meu anonimato.

O Quero participar do curso SEM que qualquer dado sobre minha participação seja utilizado para fins de pesquisa acadêmica. 